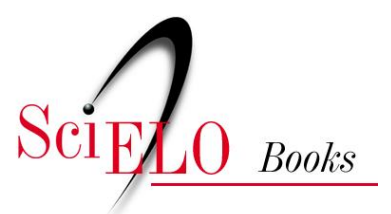

\title{
Sociedade e política no Brasil pós-64
}

\author{
Bernardo Sorj \\ Maria Hermínia Tavares de Almeida \\ (orgs.)
}

SORJ, B., and ALMEIDA, MHT., orgs. Sociedade e política no Brasil pós-64 [online]. Rio de Janeiro: Centro Edelstein de Pesquisas Sociais, 2008. p. 385. ISBN: 978-85-99662-63-2. Available from SciELO Books <http://books.scielo.org $>$.

\section{(1)(1)(2)}

All the contents of this chapter, except where otherwise noted, is licensed under a Creative Commons Attribution-Non Commercial-ShareAlike 3.0 Unported.

Todo o conteúdo deste capítulo, exceto quando houver ressalva, é publicado sob a licença Creative Commons Atribuição Uso Não Comercial - Partilha nos Mesmos Termos 3.0 Não adaptada.

Todo el contenido de este capítulo, excepto donde se indique lo contrario, está bajo licencia de la licencia Creative Commons Reconocimento-NoComercial-CompartirIgual 3.0 Unported. 


\section{SOCIEDADE E POLÍTICA NO BRASIL PÓS-64}

\section{Bernardo Sorj Maria Hermínia Tavares de Almeida Organizadores}


Bernardo Sorj

Maria Hermínia Tavares de Almeida

Organizadores

\section{SOCIEDADE E POLÍTICA NO BRASIL PÓS-64}

Rio de Janeiro

2008

centro edelstein de pesquisas sociais www.centroedelstein.org.br
Esta publicação é parte da Biblioteca Virtual de Ciências Humanas do Centro Edelstein de Pesquisas Sociais - www.bvce.org

\section{Centro Edelstein de Pesquisas Sociais}

Presidente: Joel Edelstein

Diretor: Bernardo Sorj

Coordenadora da coleção: Dayse de Marie Oliveira

Copyright (c) 2008, Bernardo Sorj, Maria Hermínia Tavares de Almeida Copyright (c) 2008 desta edição on-line: Centro Edelstein de Pesquisas Sociais

Ano da última edição: 1984

Nenhuma parte desta publicação pode ser reproduzida ou transmitida por qualquer meio de comunicação para uso comercial sem a permissão escrita dos proprietários dos direitos autorais. A publicação ou partes dela podem ser reproduzidas para propósito não-comercial na medida em que a origem da publicação, assim como seus autores, seja reconhecida.

ISBN 978-85-99662-63-2

Centro Edelstein de Pesquisas Sociais

www.centroedelstein.org.br

Rua Visconde de Pirajá, 330/1205

Ipanema - Rio de Janeiro - RJ

CEP: 22410-000. Brasil

Contato: bvce@centroedelstein.org.br 


\section{SUMÁRIO}

\section{Apresentação}

\section{1}

Bernardo Sorj, Maria Hermínia Tavares de Almeida

Introdução (quase um prefácio)

De Castello a Figueiredo: uma incursão na pré-história da "abertura".

Sebastião C. Velasco E. Cruz, Carlos Estevam Matins

O eleitorado, os partidos e o regime autoritário brasileiro

Fábio Wanderley Reis

As forças armadas e a política

René Armand Dreifuss, Otávio Soares Dulci

Desenvolvimento, urbanização e mudanças na estrutura do

emprego: a experiência brasileira dos últimos trinta anos

Vilmar Faria

Processos sociais e formas de produção na agricultura brasileira

Bernardo Sorj, John Wilkinson

O sindicalismo brasileiro entre a conservação e a mudança .... 279

Maria Hermínia Tavares de Almeida

Movimentos sociais urbanos: balanço crítico

Ruth Cardoso

Processos sociais no Brasil pós-64: as ciências sociais

Otávio Guilherme Velho

\section{Apresentação}

Em outubro de 1982 realizou-se em Manchester, Inglaterra, o Congresso Internacional de Americanistas. $\mathrm{Na}$ oportunidade organizamos um painel sobre "Transformação Sociais no Brasil pós64", que procurou apresentar uma visão dos diferentes aspectos que a temática abriga. Obviamente, não pretendíamos dar conta da multiplicidade de questões que poderiam ser levantadas, menos ainda da diversidade de visões possíveis. Ainda que o grupo tenha se restringido a uma perspectiva fundamentalmente "sociológica", certos temas centrais, como, por exemplo, o das classes dominantes, não foram incluídos. Malgrado esta e outras limitações, acreditamos que o livro constitui pelo menos um esforço no sentido de apresentar uma visão do conjunto e relativamente coerente das transformações em curso nas últimas duas décadas na sociedade brasileira. Nosso objetivo e desejo é que possa tornar-se referência e incentivo para novos e melhores estudos, capazes de proporcionar uma imagem sintética da complexa estrutura social brasileira.

Bernardo Sorj Maria Hermínia Tavares de Almeida 


\section{Introdução (quase um prefácio)}

Fernando Henrique Cardoso

Existem momentos nos quais, quase à revelia da consciência, o pensamento social registra uma mutação. Parece que isto ocorreu no Brasil. De repente, depois de anos de crítica ao autoritarismo, à exclusão social e à exploração econômica da maioria da população, os textos dos cientistas sociais começam a falar do "novo".

Obviamente, a dura crítica feita ao "modelo de crescimento dependente associado", aos efeitos sociais perversos do "capitalismo selvagem", à concentração exponencial da renda — enfim à ordem vigente — não foi descabida, nem em vão. Ela constitui um exemplo de como pôde a intelectualidade brasileira buscar padrões de integridade intelectual e política em plena vigência de um regime autoritário. Mas é, hoje, insuficiente.

Os textos que este livro reúne são os produtos de um outro tipo de situação e de preocupação. No fundo, o que eles dizem é que, a despeito de tudo, deu-se, como escrevi acima, uma mutação na sociedade e na forma de atuação dos grupos, classes e movimentos que lhe dão vida. Mutação não implica juízo de valor: não se discute aqui se "antes" (de 1964) da urbanização acelerada? da nova industrialização?) era melhor ou pior. Se o futuro será cheio de ventura ou não. E é este o encanto do livro: ele constata, aponta tendências, reconhece transformações e, vez por outra, desilude os que pensam que toda mudança estrutural aponta para a esperança.

Mas não há dúvida: o país não é mais o mesmo. Da fenomenologia crítica das fases do autoritarismo, feita por Carlos Estevam Martins e Sebastião Cruz, à análise das mudanças dos padrões de produção intelectual feita por Otávio Velho, não fica pedra sobre pedra da herança relativa à anterior visão do Brasil.

No cerne deste processo (do ângulo sociológico, pois o livro não trata da economia) estão as grandes mudanças na estrutura social: a urbanização e o sistema de empregos, como as descreve Vilmar Faria. E o livro reconhece o que custou mais a aceitar: a estrutura agrária também mudou. Capitalizou-se a economia; a grande unidade de produção exerce seus efeitos; a nova tecnologia afeta o modo de os homens produzirem e se relacionarem, como Sorj e Wilkinson o demonstra.

Nada disso é tão novo assim, dir-se-á. Por certo. E na década anterior o mesmo Faria, no que diz respeito às cidades, Brandão Lopes e Caldeira Brant (para limitar-me a exemplos de autores próximos à tradição intelectual dos escritores desta antologia) já haviam apontado as grandes transformações estruturais.

É verdade. Eu próprio andei sempre tentado — pretensão confessada é melhor do que modéstia encobridora de desvarios de auto-imagem - a escrever um livro com o título de Grande Indústria e Favela, para descrever a nova sociedade. Mas o que é próprio desta antologia é ser uma espécie de "Plataforma da Nova Geração". Não é um autor quem sintetiza; são vários que, sem plano adrede, martelam 
na mesma tecla. Não é só a descoberta do novo: é a generalização de sua consciência.

Certamente, pelas revistas de ciências sociais deste Brasil afora, ou nas centenas de papers que os congressos e reuniões científicas produzem, ver-se-ão as mil facetas da nova realidade. Em alguns setores, o novo rebenta com mais impacto. Às vezes ele vem revestido de um referencial erudito que quase o esconde, como no trabalho de Fábio Wanderley sobre o eleitorado e os partidos. Mas é só arrancar o véu do especialista para ver o ponto marcado: mesmo em pleno regime autoritário (pasmem!) prosseguiu o processo de formação da cidadania; os partidos impostos, sem deixarem de sê-lo, acabam por ter algo a ver com partidos, no sentido de permitir uma escolha, um corte político, do eleitorado. Tal como Bolivar Lamounier e eu próprio, em outros trabalhos (e alguns outros mais) insinuamos, ou dissemos. Conta menos a verificação relativa à desinformação da massa, do que a outra: a de que, apesar disso, os partidos se constituem.

Com menos espanto, o leitor verá que Dreifuss e Dulci escalpelam sem preconceitos o papel das Forças Armadas na política brasileira. Menos espanto porque Dreifuss já havia passado o bisturi no tumor do golpe de 1964. Expõe, agora, as mazelas de uma instituição que por sua doutrina nova encalhou na política e dela parece não poder sair até que venha à tona a discussão crucial: qual é o papel razoável e legítimo das Forças Armadas num país como o nosso? Os autores insinuam que há um movimento no pensamento militar que busca consonância com a atual fase de abertura política. Haverá a contrapartida de um pensamento político capaz de devolver sentido e limite à presença militar na sociedade? Até que ponto a relação entre Forças Armadas e sistema produtivo, por um lado, e entre elas e a vida política, por outro (via SNI), coloca limites à democratização em curso? Terão os políticos e os militares capacidade - e força - para redefinir tudo isso?

É óbvio que nesta altura a reflexão sobre o "novo" raspa o fundo do poço. Mudou a estrutura da sociedade; mudaram as relações entre os homens, pois também é outro o modo de produzir. Teriam mudado suficientemente as instituições e os comportamentos coletivos?

Os capítulos escritos por Maria Hermínia Tavares e Ruth Cardoso vão direto a esta questão. O "novo sindicalismo" e os "movimentos sociais urbanos" são aqui examinados com propriedade, fazendo avançar a interpretação. Num e noutro caso reconhece-se que houve a referida mutação; mas sem ilusões. Nem o novo sindicalismo quebrou a estrutura sindical herdada do Estado Novo, nem os movimentos sociais são suficientemente fortes para reformar o Estado e revivificar os partidos. Mas ambos criam novos atores, instauram novo discurso ideológico e abrem novos espaços de participação. Eis aí a questão. Ela é, aliás, dupla: o "novo" se imbrica num contexto antigo sem o revolucionar. E ao mesmo tempo se especifica. Explico-me: é certo que os movimentos sociais urbanos brasileiros têm algo de semelhante ao grass-root movimento 
americano. A luta pela negociação direta entre trabalhadores e patrões também lembra a América. Mas não são a mesma coisa. Não apenas porque o contexto é outro, mas porque cultural e politicamente estas formas de mobilização criam dimensões distintas das que prevalecem na América ou nos países altamente industrializados da Europa. É este o cerne da temática teórica do "novo Brasil". A estrutura da sociedade, a forma de movimentos sociais e os valores que norteiam a ação (todas processando-se no contexto do "desenvolvimento dependente associado") têm muito em comum com o que ocorre nas sociedades altamente industrializadas de democracia avançada. Mas não são a mesma coisa. Por quê? De pouco valeria referir apenas à "herança histórica" ou aos traços restantes do passado "colonial-exportador". E é nisto que os capítulos deste livro inovam: eles tratam os diversos aspectos da sociedade brasileira em sua singularidade; esta não consiste apenas no recozimento de influências culturais externas no fogo brando da tradição brasileira, nem na refração de um raio laser convergente que homogeneiza todas as sociedades pelas virtudes da comum industrialização. Por certo, estes fenômenos existem. Mas o que conta como desafio é a conceituação no plano positivo de uma estrutura nova e definitiva. Estrutura que não é um "fenômeno discreto", apenas brasileiro, pois existe com força de legalidade própria nas outras sociedades que se estão industrializando na periferia.O desafio é tentador. Nas páginas deste livro a outra grande questão (ao lado da forma da estrutura da sociedade, das classes), a questão do Estado, é tratada apenas indiretamente, nos capítulos sobre as Forças Armadas, os sindicatos e os movimentos sociais. Mas basta para exemplificar o mesmo terna: é preciso encontrar a "positividade" da perspectiva de análise do Estado e de seu emaranhado na nova sociedade. Não é suficiente analisar por referência às formas estatais antigas prevalecentes nos países dependentes ou às formas modernas, prevalecentes nos países altamente industrializados. Existe um blend específico que tem de ser caracterizado em si mesmo, embora ele exista também como refração.

É esta dialética — sem finalismos e sem o agente privilegiado da História a dar-lhe substância - que precisa ser recuperada. E é nesta direção que este livro se orienta. Talvez sem o fazer completamente e sem que cada página dele reflita o movimento metodológico que assinalei. Mas com força e criatividade.

São Paulo, 7 de fevereiro de 1983 


\section{De Castello a Figueiredo: uma incursão na pré-história da "abertura"}

Sebastião C. Velasco E. Cruz ${ }^{1}$ Carlos Estevam Matins

O sistema de poder instaurado a partir do golpe de Estado de 64 apresenta duas características aparentemente contraditórias. Por um lado, o sistema distingue-se pela durabilidade. Já lá se vão 18 anos de continuidade ininterrupta, não se tendo produzido, nas várias oportunidades sucessórias, um único caso de alternância entre governo e oposição. O movimento político-militar que derrubou o presidente João Goulart demonstrou possuir aquela qualidade que Maquiave1 punha acima de tudo: a capacidade de conservar o poder conquistado e ampliá-lo. Por outro lado, porém, registra-se o fenômeno da mutabilidade. Longe de ter permanecido sempre idêntico a si mesmo, o regime sofreu diversas transfigurações, ora regredindo na direção do Estado de exceção, ora progredindo na direção oposta.

São coisas diferentes, claro está, o que vem durando e o que vem mudando. $\mathrm{O}$ duradouro tem sido a permanência no poder da

1 Agradecimentos ao Social Science Research Council e à Fundação Ford, que proporcionaram recursos para o projeto "Transição de Regime Autoritário e Empresariado: Brasil, 1974-198...”. Entre fevereiro e agosto, trabalhei no CESAP - órgão da S.B.I. - no desenvolvimento do referido projeto. coalização que, desde 64, assumiu o controle do Estado. O mutável tem sido a forma assumida pelo Estado, vale dizer, o regime político propriamente dito. Esses dois aspectos — o quem e o como - longe de se antagonizarem, se complementam: as mudanças (do regime) viabilizaram a conservação (do poder). Por essa razão, talvez, o discurso oposicionista corrente costuma atribuir pouca importância às transformações ocorridas no plano "meramente" institucional.

Preferimos, no entanto, abordar a questão de um outro ângulo: sem perder de vista a existência da continuidade, procuraremos enfatizar as descontinuidades. Admitindo que o autoritarismo possa ser tratado como uma variável, suscetível de assumir diferentes valores ao longo do tempo, é forçoso reconhecer que o regime, apesar de ter-se tornado agudamente autoritário em diversos momentos, não só nunca chegou a atingir os graus extremos de intensidade registrados em outros países capitalistas periféricos (Chile Argentina) como até mesmo assumiu, em certas oportunidades, características próximas às da normalidade republicana, tal como essa expressão é contemporaneamente entendida. As idas e vindas do regime foram, ademais, facilitadas pelo fato de que nunca se chegou a implantar um conjunto plenamente estruturado de instituições autoritárias, respaldado por uma ideologia inambígua, frontalmente avessa a compromissos com o credo liberal-democrático. Por certo, tais limitações não impediram os surtos de práticas extremamente violentas que ultrapassaram os níveis de prepotência admitidos pelo marco institucional. Tal ocorreu todas as vezes que os agentes diretos 
da repressão conseguiam apelar com êxito para a chamada "excusa da necessidade". Não obstante, também é verdade que, na ausência de uma congruente cobertura normativa e valorativa, as práticas toleradas em situações críticas tenderam a tornar-se exorbitantes face ao refluxo do movimento conjuntural que as engendrara. Essas e outras características do mesmo gênero foram o que levou um especialista do porte de Juan Linz à conclusão de que "o caso brasileiro constitui uma situação autoritária mais do que um regime autoritário" $^{2}$.

Com efeito, de 64 aos dias de hoje passamos por sucessivos arranjos institucionais, cada qual combinando, em dosagens diferentes, elementos avulsos de autoritarismo, militarismo, corporativismo, liberalismo e democracia. $O$ fato de que esses arranjos se sucederam, sem conseguirem se estabilizar, sugere que o nosso objeto de estudo, longe de ser uma ordem estabelecida que se reproduz a despeito das circunstâncias, é, antes, um processo que avança de um ponto de equilíbrio instável a outro igualmente precário. Há uma dinâmica a ser captada e, para tanto, precisamos recorrer a algumas hipóteses preliminares:

1. Os momentos de intensificação do autoritarismo como, por exemplo, a edição do AI-2, em 65, ou a do AI-5, em 68, não

2 Juan J. Linz, "The Future of an Authoritarian Situation or the Institutionalization of an Authoritarian Regime: The Case of Brasil", in Alfred Stepan (ed.) Authoritarian Brazil, New Haven e Londres, Yale University Press, 1973. decorrem em linha direta do golpe de 64. Apesar de sua inegável importância, o movimento de março não pode ser erigido em principal fator explicativo das eclosões autoritárias posteriores como se, no interior daquele, estas já estivessem dadas, tal qual bombas de ação retardada. Ao impor um pesado silêncio sobre as mediações que nos conduziram a sucessivas catástrofes, as análises supostamente unificadoras soterram toda uma trama histórica complexa que, no seu tempo, além de ter sido sofrida, foi também tecida pelos que participaram das lutas empreendidas nas diversas conjunturas. Tornase necessário, por conseguinte, recuperar as determinações específicas e a dinâmica interna desses processos parciais que redundaram em recrudescimentos do autoritarismo.

2. $\mathrm{O}$ esquema maniqueísta credita à oposição apenas as mudanças positivas, de sentido democratizante, e a isenta de qualquer responsabilidade no que diz respeito às mudanças negativas, de sentido autocratizante. Pensamos, ao contrário, que a oposição é parte integrante do sistema político, não podendo a história deste ser indiferente às concepções e aos comportamentos daquela.

3. A tese de que as características do regime devem-se apenas ao golpe e aos golpistas de 64 tem também o inconveniente de obscurecer o avanço de processos mais profundos de natureza estrutural. O capitalismo contemporâneo, requerendo a crescente participação do Estado na produção de mais-valia e na reprodução da força de trabalho, exige a reformulação das esferas pública e privada, assim como a dos mecanismos, institucionais e ideológicos, que as 
articulam entre si. A proeminência que em todo o mundo vem sendo adquirida pela burocracia estatal (civil e militar), pelos meios eletrônicos de comunicação de massa, pelo discurso tecnocrático, pelos direitos sociais, pelos valores atinentes à segurança do Estado, necessariamente coloca em crise os partidos políticos, o parlamento, o conceito de lei, os processos autônomos de formação da opinião pública, as liberdades civis e os direitos políticos do cidadão. Tudo isso faz parte da problemática do capitalismo contemporâneo que, no caso brasileiro, é complicada pela questão do desenvolvimento na periferia do sistema mundial. Nem tudo, portanto, decorre do golpe de 64 .

Os que tentaram impedir a posse do vice-presidente João Goulart tiraram de seu fracasso em 61 a lição que os levou à vitória em 64. Compreenderam que, para ter êxito, o novo golpe a ser tentado precisava contar com uma base social de apoio que fosse a mais ampla e diferenciada possível. Levada à prática, essa diretriz resultou na montagem de uma complexa coalizão que incluía praticamente todas as facções das classes dominantes (do rural ao urbano, do arcaico ao moderno, do nacional ao estrangeiro, do produtivo ao parasitário) juntamente com ponderáveis parcelas da pequena-burguesia, das profissões liberais e da nova classe média burocratizada, com suas respectivas representações no plano políticopartidário. A contra face militar dessa coalização era também complexa, nela agregando-se legalistas históricos (como o próprio Castello) e conspiradores incansáveis (Ademar de Queirós, Silvio
Heck, Albuquerque Uma, Cizeno Sarmento etc.).

Não podia ser maior a desproporção entre as forças reunidas nessa coalizão e as que foram derrotadas. Quando finalmente ocorreu o confronto decisivo, os situacionistas da véspera viram-se, de repente, reduzidos a mais completa impotência.

A compreensão do pós-64 requer a análise dessa coalizão vitoriosa. Para simplificar ao extremo, vamos aqui considerá-la apenas em sua dimensão militar, assumindo por hipótese que os interesses sócio-econômicos dela participantes são representados, de forma específica, pelas diversas frações ou correntes militares. Numa segunda operação simplificadora, reduziremos a variedade dos agrupamentos castrenses a apenas quatro categorias: os sorbonistas, a linha dura, os nacionalistas de direita e as chefias que se impõem em nome da unidade e do princípio burocrático constitutivo da corporação.

As origens históricas do sorbonismo remontam à Revolução de 32, à resistência contra Vargas e o Estado Novo, à aliança com os Estados Unidos na frente antifascista da Segunda Guerra. Sua contrapartida na política civil e na esfera ideológica encontrava-se na cúpula da UDN e nos porta-vozes do pensamento liberal. Em conjunto, essas forças se opunham ao socialismo em geral e, mais especificamente, ao movimento nacional-popular (setores do PTB, PCB, esquerda militar) e ao seu companheiro de viagem, o clientelismo, seja na versão tradicional (PSD), seja na versão populista (PSP e peleguismo petebista). 
O sorbonismo não se confundia com o mero conservadorismo ou como mero reacionarismo. Muito mais do que isso, ele se definia como um dos grandes pólos de atração do sistema político brasileiro, passando a apresentar-se como alternativa real de poder especialmente depois que o governo Kubitschek consolidou seus suportes materiais ao aprofundar, tornando-se praticamente irreversível, o modelo de desenvolvimento dependente-associado. Graças à presença sorbonista, o movimento de 64 continha a possibilidade de transcender os limites de um simples golpe de Estado e de se configurar positivamente, como redirecionamento cosmopolita-modernizante que abandonaria os rumos tomados pela Revolução de 30 para inaugurar um novo ciclo da história brasileira.

Credenciando-se como a força político-ideológica mais qualificada para dirigir a coalizão golpista, o sorbonismo assumiu de fato o controle do Estado em 64, integrando maciçamente o governo presidido pelo marechal Castello Branco. Outras posições importantes do aparelho estatal, como o cargo de ministro do Exército, foram distribuídas entre os representantes dos demais setores da coalização vitoriosa. Mas o governo propriamente dito a direção política do Estado - ficou com os sorbonistas.

Junto com o poder, os sorbonistas tinham em suas mãos um problema de difícil solução: a composição da coalização vitoriosa, na qual ocupavam a posição hegemônica, tinha sido adequada para viabilizar o golpe, mas mostrava-se incompatível com o programa de governo que pretendiam executar. Interesses que precisavam ser contrariados - como os do latifúndio e os da burguesia economicamente parasitária ou atrasada em termos tecnológicos e organizacionais - encontravam-se instalados no esquema situacionista, enquanto que outros interesses, suscetíveis de participar de um pacto desenvolvimentista, encontravam-se aguerridamente entrincheirados na oposição. Assim sendo, a coalizão vitoriosa não era apenas heterogênea: era também fortemente contraditória e, mais importante do que isso, essencialmente incapaz de unificar setores dominantes e dominados num projeto policlassista que, sendo consensual entre seus defensores e majoritário· face a seus oponentes, pudesse ser implantado conforme o ideal sorbonista, vale dizer, dentro da lei e da ordem.

Parece absurdo falar de lei e de ordem com referência a um governo que se instalou pela força. Inegavelmente editou-se, com base no poder constituinte das insurreições armadas, o Ato Institucional que suspendia as garantias de inamovibilidade e estabilidade no emprego público (Art. $7^{\circ}$ ) e outorgava ao presidente da República a faculdade de revogar mandatos eleitorais e cassar direitos políticos pelo prazo de dez anos (Art. $10^{\circ}$ ). Inegavelmente, houve uma grande quantidade de intervenções arbritárias em diversos setores da sociedade (especialmente nos sindicatos), cerca de sete mil pessoas foram prejudicadas com a perda de posições ou direitos adquiridos e número muito maior foi atingido, de uma ou outra forma, pela repressão policial generalizada que se desencadeou com o golpe. 
Todavia, também é inegável que a ditadura que assim se manifestava era comparativamente branda. Por um lado, não foram extraordinariamente elevadas — nem em número, nem em custo pessoal - as baixas registra das durante o período de expurgo. Recorde-se que a linha dura reclamava cerca de cinco mil cassações de direitos políticos e obteve menos de quatrocentas. Por outro lado, a presença dos traços característicos do Estado de exceção foi notavelmente sóbria.

Para começar, decidiu-se manter a Constituição de 46, a fim de demonstrar, como dizia o intróito do Ato, "que não pretendemos radicalizar o processo revolucionário". Enquanto instituições, a liberdade de imprensa, as associações representativas e os partidos políticos não foram diretamente atingidos, ao passo que, quanto aos sindicatos, não houve necessidade de inovações legislativas, dada a vigência do estatuto corporativo não revogado pela democracia de 46. O calendário eleitoral tampouco foi alterado. O Congresso nacional foi mantido em funcionamento, tendo em vista, como esclarece o Ato, "reduzir ainda mais os plenos poderes de que se acha investi da a Revolução vitoriosa".

Além dessas, outras restrições do pleno poder merecem ser destacadas:

1. Embora a expressão "guerra revolucionária" seja utilizada e a necessidade de "drenar o bolsão comunista" seja reconhecida, o Ato não modifica a antiga lei de segurança nacional, elaborada pelo Congresso em 1953.
2. Havia dois artigos fortemente discricionários: o $7^{\circ}$ e o $10^{\circ}$, já citados. Surpreende, no entanto, a curta duração conferida à vigência de ambos. $\mathrm{O} 7^{\circ}$ expiraria no prazo de seis meses e o $10^{\circ}$, que era o mais draconiano de todos, vigoraria somente durante 60 dias.

3. O Ato foi editado sem numeração (não se cogitava de uma série) e estaria automaticamente revogado, quanto ao resto de seus artigos, em menos de dois anos (31 de janeiro de 66), expirando juntamente com o mandato presidencial. Este, por sua vez, não era um novo mandato, mas o do presidente Jânio Quadros, a ser apenas completado por seu terceiro titular. O detentor do mandato seguinte deveria ser escolhido através de eleições diretas, em conformidade com as normas da Constituição de 46.

Em praticamente todas as áreas de atuação, o governo Castello Branco manteve-se fiel ao que poderíamos chamar de ideal sorbonista: o de promover via integração institucional, o modelo de civilização realizado pelos países centrais do sistema capitalista. Assim, também, na área política. No entender dos sorbonistas, um regime liberal-democrático moderno precisaria possuir, no mínimo, três virtudes: 1) agilidade nos processos decisórios; 2) capacidade de controlar as ameaças de subversão da ordem; 3) garantir aos partidos políticos o direito efetivo de se alternarem no poder mediante livre disputa eleitoral. Evidentemente, o regime de 46 deixava a desejar em cada um desses pontos.

Detenhamos-nos no último. De 45 a 64, a UDN e seus aliados nunca tiveram a possibilidade real de competir em pé de igualdade 
com seus adversários — O PSD, o PTB e o PSP — a favor dos quais o sistema político era estruturalmente enviesado. Para corrigir as distorções que marginalizavam os udenistas e seus aliados, o governo Castello Branco empreendeu uma série de reformas.

Uma das mais importantes, a da administração pública, visava racionalizar a organização e os métodos de trabalho da máquina burocrática de modo a capacitá-la para o desempenho eficiente das funções que lhe correspondem no quadro do capitalismo maduro, dominado pelas grandes empresas. No plano político-partidário, tal reforma tenderia a destruir as fontes de alimentação das práticas clientelistas que bloqueavam a alternância no poder. Tratava-se de fechar as portas do tesouro e dos empregos públicos que o Estado cartorial franqueava aos dirigentes do PSD do PSP.

Outra grande iniciativa foi a proposta de Reforma Agrária, inspirada no conceito de imposto territorial progressivo. Tratava-se de eliminar os proprietários incapazes de modernizar seus estabelecimentos, ao mesmo tempo em que seria gerada, por meio de apoio governamental, uma nova pequena-burguesia rural, autônoma e competitiva, a coexistir com as médias e grandes unidades capitalistas. Atingindo os currais eleitorais do PSD, a reforma criaria bases de apoio social afinadas com o partido (sorbonista) da modernização conservadora.

A terceira reforma das estruturas que condicionam o comportamento eleitoral das massas populares foi a que incidiu sobre as relações dos sindicatos com a Previdência Social e o Ministério do
Trabalho. Nesse caso, o alvo visado era o PTB. Tratava-se de lhe retirar o poder de patronage resultante da inserção dos sindicatos nos aparelhos estatais. O projeto envolvia duas mudanças fundamentais. Por um lado, previa a universalização do direito de acesso aos benefícios proporcionados pelo sistema; por outro, estipulava a completa unificação administrativa e a abolição do conceito de representação classista na gestão dos órgãos assistenciais e previdenciários. Tais transformações fariam com que essa gigantesca fonte de recursos financeiros e políticos deixasse de ser uma reserva de caça do petebismo.

Providências desse tipo, assim como outras que a seguir mencionaremos, testemunhavam a disposição de restabelecer um. regime. (reformado) de cunho liberal-democrático. Não por decorrência de uma postura idealista. $\mathrm{Na}$ verdade, os sorbonistas não tinham outra escolha. Como poderiam apostar na exacerbação do poder militar se justamente aí residia os seus pontos fracos, mal representados como sempre foram no seio da tropa? Seu ponto forte estava no verso da medalha: estava na sociedade civil onde predomina, como se sabe, o grande capital. Dessa vinculação provinha igualmente a extraordinária sistematicidade do programa posto em prática pelos sorbonistas. Tão importante quanto isso, as transformações em curso estavam conferindo caráter estrutural e irreversível à derrota inicialmente sofrida no plano político pelas forças nacionalistas e populares. Introduzidas em ritmo superacelerado, as múltiplas reformas estavam sepultando o passado 
e criando novas condições objetivas que invalidavam por completo a possibilidade de restauração da situação deposta em 64.

Os sorbonistas, porém, não atuavam no vazio. Pelos lados, chocavam-se com a linha dura e os nacionalistas de direita; pela frente, esbarravam com a oposição, que crescia a cada dia, na medida em que iam se dando as defecções no "campo revolucionário"; por baixo, era indócil e instável a base de apoio político-parlamentar com que contavam. Como agravante, eram as incoerências mesmas de seu projeto que surgiam como fontes de dificuldades. Assim, não admira tenha sido tão imperfeita a passagem dos planos à realidade.

Os nacionalistas de direita, ao mesmo tempo que ofereciam resistência à política econômico-financeira que aprofundava a experiência externa e os desequilíbrios internos, davam apoio aos oficiais de linha dura, empenhados em levar adiante a repressão revanchista contra a orientação legalista e reconstitucionalizante que o governo procurou impor, uma vez encerrada a assim chamada fase de depuração. Tendo conquistado ascendência nas comissões de inquérito policial-militar e detendo posições no alto comando revolucionário, as alas radicais valiam-se dessas bases de poder para desafiar a autoridade presidencial e investir contra os remanescentes da situação deposta, seja no plano federal, seja no âmbito estadual, onde impunham medidas decretadas nas águas da revolução para atender interesses facciosos da política local. Finalmente, deve-se pelo menos registrar um ponto crucial cuja análise não podemos desenvolver aqui: todos esses movimentos de insubordinação intramuros eram incentivados e, em certas áreas civis e militares, diretamente liderados por Magalhães Pinto e Carlos Lacerda, na qualidade de candidatos inarredáveis à presidência da República.

Ganhando aqui e perdendo ali, Castello Branco foi registrando pequenas vitórias na contenção dos anseios direitistas. Uma das mais importantes foi a observância do prazo — vencido a 15 de junho de 64 para a cassação de mandatos e suspensão de direitos políticos. Com o desaparecimento desse poder extinguia-se, tecnicamente, o Estado de exceção: para ressuscitá-lo seria mister um novo surto revolucionário, que outra vez suspendesse a eficácia do ordenamento jurídico. Nada menos que isso foi tentado pelas lideranças civis e por chefes militares, como o marechal Taurino de Resende, que presidia a Comissão Geral de Investigações encarregada de coordenar os inquéritos conduzidos pelos coronéis da linha dura. Castello Branco resistiu. Sem dúvida, assinou a última lista de cassações, encabeçada por Kubitschek; mas recusou-se a prorrogar a vigência do arbítrio. Em seguida, não atendeu aos que lhe reclamavam a decretação do estado de sítio. Posteriormente, rejeitou a criação de novos instrumentos para substituir os poderes cessantes outorgados pelo Artigo $7^{\circ}$. Conforme observou na época o jornalista Carlos Castello Branco, "a política de repressão não atendeu aos interesses e às reivindicações dos que a preconizavam (...) Os partidários da linha dura são hoje pessoas frustradas e descontentes com o governo. Em cada Estado, do Rio Grande do Sul ao Acre, há queixas". Vários governadores, com dossiês ultimados pela Comissão Geral de 
Investigações, "foram salvos da degola pela moderação com que o presidente usou dos poderes que lhe atribuiu o Ato Institucional". ${ }^{3}$

O enquadramento do poder militar no marco jurídico constitucional tinha sido provavelmente prematuro. Longe estavam do ponto de saciedade as fúrias mobilizadas para efeito de desfechar o golpe. A onda revolucionária, forçada a canalizar-se quando ainda estava em plena atividade expansiva, teve de ser várias vezes contida, sempre com grande dificuldade, durante as crises provoca das pela linha dura, cujas atividades se intensificaram a partir de outubro, tão logo caducou o Artigo $7^{\circ}$. As pressões que se exerceram, de forma crescente e aparentemente orquestrada, geraram situações críticas no Ceará, no Maranhão, em São Paulo e, especialmente, em Goiás, onde se concentrou a resistência de esquerda sob a liderança do governador Mauro Borges. O próprio Congresso foi colocado em posição periclitante, atingido nas pessoas do presidente do Senado e do presidente da Câmara dos Deputados. Foi contestada igualmente a autoridade do ministro da Justiça (liberal de quatro costados), bem como a do Supremo Tribunal Federal, nas seguidas tentativas que visavam desvertebrar o Poder Judiciário. Em fins de novembro, com base no caso Mauro Borges, os duros reivindicaram abertamente um novo Ato Institucional para repor a Revolução em marcha. Seu objetivo, como dizia o presidente, era o de se constituírem em "força autônoma". Não obstante, tudo foi feito mais ou menos na forma da

3 Carlos Castello Branco, Os Militares no Poder, vol. 1. lei, inclusive a intervenção federal em Goiás, que se processou com o governador Mauro Borges protegido por um habeas-corpus.

Quando começa o mês de dezembro de 64 o pior parecia já ter passado. Apesar dos arranhões, reinava a Constituição de 46 e o governo, ainda que desgastado, encontrava-se a cavaleiro da situação. Os focos de tensão remanescentes do pré-64, embora não extintos, estavam pelo menos sob controle. Para o governo, tratava-se de olhar para a frente. $\mathrm{O}$ grande passo seguinte, no caminho da recuperação da normalidade, seria dado se a sociedade civil, organizada nos diversos partidos políticos, conseguisse atravessar as eleições de outubro de 65 sem se chocar contra a resistência das forças radicais.

Tal, entretanto, não se deu. Apesar das providências legais adotadas a fim de afastar do pleito candidatos tidos como "não assimiláveis" (Sebastião Paes de Almeida, em MG; Hélio de Almeida e Lott, na GB), foi enorme a reação provocada nos círculos militares pelos resultados eleitorais, que davam ã oposição a vitória em 5 dos 11 estados, entre os quais os dois mais importantes - Minas e Guanabara.

Instigada além dos limites, a direita fortaleceu-se a ponto de impor a edição do Ato Institucional $n^{\circ} 2$. Só então, e não antes, o regime mudou no sentido do autoritarismo recrudescido. A ditadura, que parecia caminhar para o recesso, estava de volta mais forte do que antes. A ressurreição incluía o retomo dos poderes para cassar mandatos e suspender direitos políticos, a extensão do foro militar aos civis, a limitação da livre manifestação do pensamento, a 
suspensão das garantias de vitaliciedade e inamovibilidade, a extinção dos partidos políticos, a outorga da faculdade de decretar intervenção nos estados, de baixar decretos-leis em matéria de segurança nacional e de declarar em recesso as casas legislativas. Ficavam assim anuladas não só as conquistas eleitorais realizadas pela oposição como as pretensões políticas do grupo sorbonista.

Com efeito, o presidente Castello Branco passaria a jogar, daí para diante, na defensiva. Tendo perdido toda e qualquer condição de comandar o processo de sua própria sucessão, uma vez que, atuando na crise como mediador entre os radicais e os sorbonistas, o ministro do Exército, Costa e Silva, havia se tomado um candidato inarredável, só restava a Castello Branco a possibilidade de influir na margem, introduzindo medidas restritivas ou acauteladoras. Já no bojo da crise de outubro havia tentado reduzir o alcance do novo Ato, contrapondo um projeto alternativo, menos drástico, de simples reforma constitucional e procurando obter sua aprovação pelo Congresso, a fim de evitar que fosse outra vez invocado o poder constituinte da Revolução. Essas manobras não tiveram êxito, inclusive porque o Congresso se recusou a colaborar. Em compensação prevaleceu, como dado crucial para a análise da evolução do regime, a tese da vigência limitada: o novo Ato expiraria a 15 de março de 67, juntamente com a posse do próximo presidente.

Castello Branco valeu-se do tempo que lhe restava à frente do governo para elaborar uma nova Constituição, cujos dispositivos, supostamente mais ajustados aos requisitos do Estado contemporâneo, evitariam os impasses atribuídos à Carta de 46. Confirmando a mudança ocorrida na correlação de forças (derrota da esquerda, recuo do centro e ascensão da direita), foram elaboradas durante esse período a nova Lei de Imprensa e o Decreto-Lei 314, promulgado em março de 67 e conhecido como Lei de Segurança Nacional. Este último diploma, sem dúvida um monstrengo do ponto de vista jurídico, foi justificado em função da crescente obsolescência da Lei 1802, de 53, que até então regulava a matéria sem ter incorporado a posterior evolução do pensamento militar, cada vez mais voltado para as questões relativas à subversão da ordem interna e a necessidade de dotar o Estado de instrumentos eficazes de autodefesa.

A consideração do período Castello Branco é crucial para a análise do regime autoritário no Brasil, não só porque nele estão postos quase todos os elementos que, exacerbados em seu grau máximo nos anos seguintes, conformariam a conjuntura que veio a desaguar na crise de 68 e na edição do AI-5, mas também porque nele já está claramente colocado o dilema que perpassa toda a história desse regime, até os nossos dias de cinzenta abertura. Com efeito, se o relato extremamente sucinto que fizemos até aqui põe em tela o conflito entre castelistas e duros e sua permanente disputa pela definição do rumo a ser imprimido ao processo político, muitas perguntas ficariam no ar se não incorporássemos na análise pelo menos dois outros aspectos: o papel desempenhado nessa conjuntura pelas oposições e as contradições que habitavam o projeto sorbonista. 
No que tange à oposição — e aqui podemos nos referir a ela em seu conjunto, desprezando os seus muitos e profundos contrastes — o ponto a destacar é a sua quase total incompreensão com respeito à natureza da ruptura verificada com o movimento de 64. Apesar das evidências em contrário que se somavam, ela continuava a mapear a realidade nos termos da situação antiga, encarando a intervenção militar de abril como um episódio de curta duração, análogo a outros vividos no passado, dos quais se distinguiria basicamente pelos seus excessos e pelo tamanho de sua incontida pretensão. Incapaz de reconhecer o caráter geral, estratégico, da mudança ocorrida, ela persiste em praticar o padrão tradicional de política, recorrendo aos mesmos expedientes, fixando-se em objetivos formulados no período anterior e que, cada dia mais, se revelavam fantasiosos. Não é outra a razão do comportamento desafiador, provocativo mesmo, dessa oposição, traço que vamos observar inclusive em grupamentos que se notabilizaram na história brasileira pela acentuada prudência e permanente disposição ao entendimento e às fórmulas de compromisso. Essa é a postura que se reflete, por exemplo, num lance como o do retorno de Juscelino ao Brasil e na recepção que lhe fazem. "O Sr. Juscelino regressou de Paris, na ocasião em que se faziam as primeiras apurações da eleição e resolveu desfilar, seguido dos seus correligionários, em cortejo motorizado, pelas ruas do Rio de Janeiro, fato considerado afrontoso à Revolução, que levou a aumentar a irritação no meio militar." Quem narra o episódio é um "duro", o general Jayme Portella; ele prossegue: "O Coronel
Ferdinando de Carvalho, encarregado de um inquérito policial militar para apurar atividades subversivas... convocou o Sr. Juscelino para ser ouvido. A convocação do SI. Juscelino causou um reboliço em áreas políticas, em geral, pois achavam desconsideração ser ele ouvido em inquérito". ${ }^{4}$ E, no entanto, no quadro de uma crise militar grave, contestados como vinham sendo os resultados do pleito, um desfecho como esse não era de todo imprevisível.

Aos olhos da oposição, o governo militar afigurava-se como uma ditadura pura e simples, cujo apoio inicial fora rapidamente maltratado. "Durante os primeiros tempos após o 1 de abril, ... as vítimas eram confinadas, senão materialmente, sem dúvida moralmente. Os cidadãos comuns as temiam como vítimas obscuramente culpadas das três iras dos deuses, e delas se afastavam por prudência. Mas hoje é espantosa a transformação. Todos as procuram movidos por um generoso e por vezes inarticulado sentimento de reparação. Nesse movimento de aproximação aos cassados, às vítimas da ditadura militar... está a prova de que a ditadura já é uma sobrevivência no tempo. (grifos nossos) O povo brasileiro em sua imensa maioria já lhe retirou qualquer apoio... Agora é a ditadura que se vai confinando de mais a mais, num crescente isolamento do povo representado por todas suas camadas."

4 Jayme Portella de Mello, A Revolução e o Governo Costa e Silva, Rio de Janeiro, Guavira Editores, 1979, p. 277.

5 Mário Pedrosa, "O Processo da Redemocratização", Correio da Manhã, 25.9.1966. 
Carente de bases, corroída por dissensões internas — a análise não augurava à ditadura um futuro auspicioso.

O equívoco da oposição não poderia ser mais drástico. Ressalve-se, entretanto, esse fato: a incompreensão demonstrada ante a nova realidade emanada do golpe não era apanágio dos derrotados. Também no campo de lá, entre os que "fizeram a Revolução" e/ou aplaudiram a sua vitória, o grau de percepção sobre o que se passava, em muitos casos, não foi mais apurado. Aqui também vamos constatar comportamentos informados por uma visão que atribuía ao movimento de 64 caráter e objetivos muito limitados. Observemos um homem como Lacerda, agarrando-se com unhas e dentes à quimera de uma candidatura presidencial que, desde os primeiros dias após o golpe, sentia escapar entre os dedos de sua mão. Atentemos para os seus movimentos, a intensidade, o tom desabrido de sua crítica, primeiro voltada contra figuras de ministros, depois contra o próprio Castello. Esse tipo de cena ele já havia montado inúmeras vezes ao longo de sua carreira política, com inegável sucesso. Entretanto, os tempos haviam mudado. Pensemos em outro tipo de gente, aqueles liberais puros que, em diferentes momentos, recusaram-se a transigir buscando manter-se fiéis ao que pregavam. Num Milton Campos, abandonando a pasta da Justiça dias depois das eleições de outubro de 65, ao pressentir quais seriam os próximos passos. Em Adauto Cardoso, rejeitando "o Poder Constituinte, inerente a todas revoluções" e tentando em ação desesperada fazer julgar, à luz dos princípios constitucionais, decisões do poder militar. ${ }^{6}$ Os exemplos poderiam ser multiplicados, mas não mudariam a lição. Para todos esses, a cada ato de afirmação da nova ordem, mais ela parecia distanciar-se de seus "legítimos propósitos".

Os homens fazem a história, mas não sabem com exatidão que história fazem. O sorbonismo, tampouco, logra escapar ao círculo de giz desse lugar-comum filosófico. Escolhido, depois de venci das as resistências de Costa e Silva, para ocupar a presidência da República, numa autêntica "decisão revolucionária" a ser posteriomente referendada pelo Congresso, Castello Branco comporta-se como candidato e, nessa qualidade, encontra-se secretamente com Juscelino e a cúpula do PSD que, em troca das garantias obtidas, emprestamlhe o apoio solicitado. ${ }^{7}$ O PSD cumpriu a sua parte no acordo, e até a primeira semana de junho compôs, com a UDN e partidos menores, o bloco parlamentar, de 250 deputados, que se formara para dar apoio ao novo governo. $\mathrm{O}$ decreto de 8 de junho, cassando o mandato e os direitos políticos de Juscelino, vai determinar o esfacelamento desse bloco, tornando precária a base de sustentação de Castello no Congresso. Mas não apenas isso: tendo como pano de fundo o compromisso antes aludido, esse ato será vivido como uma traição e contribuirá fortemente para exasperar o ânimo da oposição.

Informações sobre o episódio da cassação de Juscelino são

6 Como presidente da Câmara dos Deputados, Adauto Lúcio Cardoso decide submeter ao plenário a constitucionalidade das cassações de mandatos políticos realizados em outubro de 66, daí resultando o fechamento temporário do Congresso e sua posterior renúncia àquele cargo.

7 Jayme Portella, op. cit., pp.203 e segs. 
disponíveis. Sabemos que Castello e a sua assessoria política não a desejavam. Sabemos, ademais, que Castello, pessoalmente, resistiu até o último momento, cedendo apenas ante a pressão incisiva de seu ministro da Guerra. No entanto, não é este o aspecto que desejamos enfatizar. Mais importante, de nosso ponto de vista, é a ambigüidade que o seu comportamento denota — o seu gesto de "candidato" (quando se tratava já de "delegado da revolução") e a sua atitude de "chefe revolucionário" (quando procurava vestir a fantasia de presidente constitucional).

Essa duplicidade, vamos constatá-la em todos os posicionamentos de Castello e em toda a sua obra. Líder de um movimento que galvanizou amplas parcelas da opinião pública em nome da ordem e da defesa da democracia ameaçada, ele sofreu, por assim dizer, as consequiências da facilidade surpreendente da vitória. Senhores da situação a uma simples movimentação de tropas, os militares no Brasil assumem o poder atados, pelos apoios com que contavam e por sua própria retórica, às instituições e às práticas da velha ordem. É sob essa luz que adquire sentido a decisão de fazer eleger o novo presidente pelo Congresso. É nessa perspectiva, também, que se compreende o caráter limitado do Ato Institucional de 9 de abril de 64, cabendo sublinhar este fato: esse diploma é promulgado antes da posse de Castello, pelos ministros militares que compunham então um auto-intitulado Comando Supremo Revolucionário. Apenas desse ângulo torna-se inteligível a escolha de Castello para um mandato tampão de menos de dois anos e o compromisso de substituí-lo através de eleições diretas. A essa altura, os "objetivos da revolução" parecem tópicos e de consecução fácil: "Fixaram a vigência daquele diploma (o Ato Institucional) até 31 de janeiro de 1966, quando seria empossado o futuro Presidente da República, pois julgavam que um período de um ano e dez meses seria o bastante para colocar o País nos eixos e entregá-lo a um novo Presidente". 8

Muito cedo, porém, começam a surgir indícios de que tal avaliação teria sido revisada. Assim, já em abril de 64 Lacerda ouvia de um prócer da UDN a sugestão de que deveria abdicar de sua candidatura e, recusando-a, com toda razão atalhava: "Ora, se começamos por abrir mão da candidatura da UDN, provavelmente a de Juscelino não vai existir, então não haverá candidato; então não haverá eleições". ${ }^{9}$ Em junho, como sabemos, Juscelino é cassado. Pouco depois, no dia 22 de julho, a Emenda Constitucional n ${ }^{\circ}$, que estabeleceu o adiamento das eleições com a prorrogação dos mandatos, era mais uma evidência que se somava. A essa altura, com as principais lideranças da oposição alijadas e Lacerda em processo de ruptura com o governo Castello, as eleições presidenciais já se haviam transformado em uma miragem.

A versão oficial desse episódio retrata um Castello reticente,

8 Idem, ibidem, p. 196.

9 Carlos Lacerda, Depoimento, Rio de Janeiro, Editora Nova Fronteira, p.304. Olyrnpio Editora, 1975, pp. 85 e segs.; Daniel Krieger, Delde aI Minõel, Rio de Janeiro, Livraria José Olyrnpio Editora, 1975, pp. 179 e segs. 
aceitando a contragosto a prorrogação de seu mandato, rendendo-se apenas ao argumento final de que a decisão seria do Congresso. ${ }^{10} \mathrm{O}$ próprio Castello, na época, fez questão de externar publicamente a sua opinião:"As pessoas que me falaram sobre o assunto, sempre respeitaram o meu ponto de vista contrário à proposição do Senador João Agripino. Apesar da minha repetida rejeição à ideia, muitos políticos trabalharam para a sua consecução, formando-se mesmo uma corrente favorável e ponderável no meio revolucionário e político. Agora é uma situação de fato. Pessoal e politicamente preferiria terminar o meu mandato a 31 de janeiro de $1966 "{ }^{11}$

Não temos razão alguma para duvidar da sinceridade dessas palavras. Mas..., não deixa de ser curioso. No plano político o governo Castello aparece como um suceder de derrotas. Não queria a cassação de Juscelino, mas foi obrigado a realizá-la; opunha-se à prorrogação de seu mandato, mas acabou por aceitá-la; convocou as eleições de outubro de 65 contra as resistências da oficialidade "dura", mas, logo a seguir, editou o AI-2 para apaziguá-la; queria um nome identificado com o seu ideário para substituí-lo na Presidência, mas assistiu impotente ao crescimento da candidatura contrastante de seu ministro da Guerra. Os fatos são indiscutíveis, mas isso não nos impede de considerá-los mais detidamente, buscando apreender a sua lógica. O que Castello não conseguiu, já sabemos. Talvez conviesse

10 Luís Viana Filho, O Governo Castello Branco, Rio de Janeiro, Livraria José.

11Nota divulgada no dia 24.6.64, apud Jayrne Portella, pp. 226-227. atentar um pouco para os seus sucessos — que não foram poucos nem menores - e indagar, finalmente, das relações que porventura possam existir entre o que ele fez e não fez, entre êxitos e fracassos.

Essa interrogação é em si mesma iluminadora. Porque, ao contrapor as frentes principais em que se desdobrou o governo Castello, ela faz ressaltar com toda nitidez a discrepância entre a moderação dos objetivos num plano - a frente política - e a enormidade da ambição que o inspirava nei outro - o campo das reformas econômico-sociais. Como dissemos no início deste artigo, o sorbonismo ascende ao poder munido de um amplo programa de reformas destinadas a remover os obstáculos à expansão do capitalismo no país e a viabilizar a plena configuração do modelo de desenvolvimento esboçado na segunda metade da década passada. Desde o final dos anos 50, a tarefa de elaborar esse "macroprograma de governo" foi desincumbida por agências privadas, que reuniam técnicos e empresários e operavam em estreita conexão com a ESG. Para o sorbonismo, o movimento de 64 tinha, no fundamental, esse sentido: permitir a implantação desse conjunto de reformas que não podiam mais ser adiadas. Essa, talvez, a principal diferença que singularizava o sorbonismo enquanto "partido militar", distinguindoo radicalmente dos demais grupos envolvidos na intensa atividade conspiratória que precedeu o golpe. Neste sentido, é revelador o comentário do general Portella: "... a visita do General Sarmento serviu para a constatação de um fato curioso, que também ao Dr. Marcondes Perraz causou estranheza. Enquanto no QG do General 
Costa e Silva, dadas as circunstâncias, atuava o Comandante por intermédio de oficiais de ligação e através de telefones, dando ordens e recebendo informações, o QG do General Castello - um apartamento residencial como o outro - funcionava como um escritório, em atividade que intrigou os dois visitantes e somente veio a ser esclareci da dias depois. Vários datilógrafos trabalhavam febrilmente, com os dedos metralhando incessantemente as máquinas e a atenção concentrada em sua tarefa ... Soube-se depois que, já naquela noite, os assessores do General Castello preparavam um plano de emergência para o Governo, esperando fazer dele o sucessor de João Goulart". ${ }^{12}$

Castello assume a Presidência em abril de 1964 para cumprir um mandato-tampão de um ano e dez meses,; no entanto, ele planeja para uma década. A contradição entre a exigüidade de tempo e as proporções do projeto. Este, o primeiro dado afixar.

Mas não é só isso. O conteúdo de suas políticas — social, econômica, exterior — não é indiferente à análise. Com efeito, ao comprometer-se, antes de tudo, com a sua implementação, ao recusar-se obstinadamente a negociá-las, ao dedicar todo o seu esforço a "isolar" política e economia esta devendo ficar a cargo dos detentores do saber, da ciência, dos tecnocratas - Castello não apenas violentou os derrotados, mas, além disso, chocou-se com a sua própria base, alienou apoios com que inicialmente contava. Não é

12 Idem, ibidem, p. 137. por acaso que o alvo de Lacerda em suas primeiras fricções com o governo foi exatamente a política econômica. Idem Magalhães Pinto e tantos outros. E se olhamos para a política exterior? Quais as condições internas necessárias para a sustentação da política de alinhamento automático com os Estados Unidos, para <> envio de soldados brasileiros a uma república distante cujos anseios de libertação o país grande do norte decidira sufocar?

Por uma e outra razões — a discrepância entre a limitação do tempo e a amplitude do programa, de um lado, e, de outro, a orientação mesma de suas diretrizes - o governo Castello foi exercido mediante o uso farto e generoso dos mecanismos que a exceção lhe facultava. Legislar por decretos em ritmo frenético. Depoimento, em versão livre, de um participante: "Reuníamos num pequeno prédio aqui no centro onde funcionava o EPEA. ${ }^{13}$ Éramos 15 ou 20, coordenados por Campos que sempre presidia as sessões. Discutíamos horas seguidas a respeito dos mais variados temas. Depois, o Bulhões Pedreira, que não era economista, mas um homem de percepção extremamente aguda e uma memória fabulosa, o Bulhões Pedreira sentava-se à máquina e dava forma jurídica ao que havia sido decidido como pontos consensuais. ${ }^{14}$ Nos dias seguintes, estava lá o documento nas primeiras páginas do jornal.

Em momentos vários Castello foi obrigado a ceder ante a

13 Antiga denominação do atual IPEA - Instituto de Pesquisas Econômicas Aplicadas.

14 Entrevista a um dos autores. 
pressão da linha dura. Na análise corrente, essas são apresentadas como efemérides de uma história específica, como episódio das dissensões militares. "Recuou porque não tinha força na tropa ... ". Acreditamos poder avançar um pouco além dessa observação banal. Quando se mobilizavam, quando exigiam, quando externavam indignação, os militares duros apelavam à legitimidade revolucionária. Repugnava-lhes a ideia de que conciliação, a barganha, o respeito reverente às leis _ "as mesmas que se demonstraram ineptas para barrar o avanço da subversão entre nós" - que o compromisso com os restos do passado pudesse deter ou mesmo frear a marcha da "Revolução". Fizemos mal quando cobrimos de ridículo essa retórica desvairada. Uma vez, pelo menos, leiamos com seriedade o diploma fundador em que ela se calcava o preâmbulo do Ato Institucional. O que ele reza?

"A Revolução vitoriosa se investe no exercício do Poder Constituinte"; "a Revolução vitoriosa, como Poder Constituinte, se legitima por si mesma"; "Ela edita normas jurídicas, sem que nisto seja limitada pela normatividade anterior à sua vitória". "Os chefes da Revolução vitoriosa ... representam o Povo e em seu nome exercem o Poder Constituinte, de que o Povo é o único titular." "Fica bem claro que a Revolução não procura legitimar-se através do Congresso. Este é que recebe deste Ato Institucional ... a sua legitimação." Nos quadros dessa formulação doutrinária, que postula uma relação expressiva e direta entre os chefes da Revolução — detentores de um poder incontrastável - e o povo entidade abstrata em que se fundamenta a sua legitimidade — a decisão de preservar em suas linhas gerais a Constituição de 46 e de manter em funcionamento o Congresso estabelece um compromisso extremamente frágil, cuja condição de vigência é a perfeita ductilidade das instituições do Estado (o Legislativo, o Judiciário) aos ditames da vontade revolucionária.

É em nome desses princípios que os jovens oficiais de linha dura repetidas vezes fazem ouvir a sua voz. Mas — este é o ponto fundamental é neles também que se baseia o governo Castello. Não apenas pela sua origem, mas pela absoluta necessidade de recurso a eles para levar a cabo as suas metas programáticas. Presidente e revolucionário, forçado permanentemente a assumir este último papel para vencer as resistências que a implementação das políticas de seu governo suscitava, ante as investidas da direita os seus flancos estavam quase sempre abertos.

Tudo isso fica mais evidente ainda quando pensamos em que condições poderia dar-se o confronto do sorbonismo com a linha dura militar e qual seria o seu significado. Nesse caso, a "inabalável coesão das forças armadas" teria sido rompida, admitamos, para efeito de raciocínio, com a vitória de Castello. Mas não seria o mesmo Castello. A própria Revolução, em virtude desse fato, teria passado à história.

Em julho de 64, como em outubro do ano seguinte e em 66, no episódio da sucessão, a correlação no seio das Forças Armadas desfavorecia o sorbonismo. Mas este não é um fato militar mas 
político. Em outras palavras, Castello perdeu politicamente algumas batalhas. Quando olhamos em conjunto o seu governo, quando fazemos o balanço global de sua obra, a convicção se afirma: perdeu as batalhas necessárias para vencer a guerra.

Com a posse de Costa e Silva não se inicia apenas o mandato de um novo presidente. Naquele momento terminava um segundo ciclo de expansão autoritária, marcado pela seqüela de expurgos, perseguições e arbitrariedades. Em contraste com esse quadro, inaugurava-se em 15 de março de 67 um novo período constitucional em que as liberdades públicas, as instituições representativas e a autoridade da magistratura - ainda que gravemente restringidas e ameaçadas pela legislação antes mencionada — tinham sido restabelecidas.

Juntamente com a transformação do regime, mudara também a estrutura da coalizão dominante. Com a reviravolta de outubro de 65 , o sorbonismo entrara em processo de retração para ser finalmente marginalizado pela linha burocrática, pelos duros e, especialmente, pelos nacionalistas de direita que conquistaram posições de influência junto aos centros governamentais de decisão. Embora os sorbonistas não tivessem sido expelidos na coalizão, a modificação do regime deu lugar à reordenação do bloco no poder, viabilizando a permanência da mesma coalizão, embora com o novo perfil que dava saliência aos adversários da Sorbonne.

Para explicar o que iria se passar no transcurso do governo Costa e Silva tem sido invocado o descontentamento popular, das classes médias, de setores do empresariado e dos demais interesses contrariados, seja pela opressão autoritária, seja pelas condições econômicas. Esquecendo que tais insatisfações estavam presentes e eram tão ou mais sentidas na conjuntura anterior, esse tipo de explicação não leva em conta justamente as duas mudanças de capital importância que acabamos de assinalar: a reconstitucionalização do Estado e a substituição do "partido" no poder, com a conseqüente redefinição do conteúdo das políticas governamentais.

Em termos de regime, o período que então começava caracterizava-se por aquilo que hoje se chama de abertura política. Ao mesmo tempo, o slogan da humanização coloria as diretrizes da ação governamental. Estavam de volta, no âmbito da política interna, o desenvolvimentismo e as metas de integração nacional e promoção social, enquanto que, na política externa, retomava-se o fio do nacionalismo terceiro-mundista. Para explicar o que iria se passar é preciso levar em conta — além das frustrações continuadas — as esperanças despertadas e a autoconfiança ressurgida.

Daí vinha o ânimo que organiza a Frente Ampla. Em seu programa, a Frente reclamava, entre outros objetivos a serem perseguidos, a retomada do desenvolvimento econômico, a preservação da soberania nacional e a restauração do poder civil. Três dias após a posse do novo presidente, Lacerda reconhecia que as diretrizes traçadas pelos ministros do Planejamento e do Interior eram de fato as mais apropriadas para o país. Logo depois, Kubitschek diria outro tanto. Tendo voltado ao Brasil na leva de exilados que 
regressavam sob as garantias dadas pelo próprio presidente da República, Kubitschek não escondia sua confiança no restabelecimento das liberdades democráticas, nem sua simpatia pela política externa anunciada pelo governo. Antes que o mês de março chega-se! ao fim, a ala esquerda do MDB abandona a ideia de criar uma Frente Popular e começa a negociar sua adesão à Frente liderada por Lacerda: a tese de não combater o governo Costa e Silva figurava entre os pontos em tomo dos quais havia acordo. No começo, portanto, predominava a paz.

A trégua só seria rompida mais adiante, em fins de agosto. Lacerda, que mobilizara a direita para impor a sua candidatura contra a vontade de Castello Branco, iria agora mobilizar a esquerda para disputar com a direita a sucessão de Costa e Silva. Em passos rápidos, as posições foram se radicalizando. Por parte da Frente, a tendência contestatória se manifestaria no pacto de Montevidéu (incorporação de Goulart e dos petebistas - setembro), na aproximação com Jânio Quadros e Leonel Brizola, nas posições assumidas pelos chamados parlamentares ideológicos, que desistiram da luta dentro do MDB para se engajar nas atividades da Frente. Por parte das forças situacionistas vão crescendo os protestos da direita. Dentro em pouco a Frente seria classificada de "movimento destinado a reconstituir a situação anterior à revolução de 64", nas palavras do ministro Albuquerque Lima.

Alguns pontos merecem ser destacados. 'Em primeiro lugar, deve-se ressaltar a relativa liberdade com que se desdobra, por mais de um ano, a articulação frentista. A Portaria que acaba proibindo suas atividades é de abril de 68, o que significa que só foi baixada depois que as pressões exercidas pela Frente se conjugaram com a irrupção do movimento estudantil. Em segundo lugar, não se pode esquecer que a Frente consistia na busca de uma alternativa política construída por fora da ordem legal e do quadro constitucional vigentes: por um lado, ela ignora a proscrição das lideranças afastadas pela revolução; por outro, ela ultrapassa as instituições representativas, dando as costas para o Congresso e, especialmente, para o MDB, vale dizer, para a organização política constituída como partido da oposição (pejorativamente qualificado de "oposição consentida"). Finalmente, o comportamento do MDB introduzia um fator sutil na marcha do processo histórico: tal como acontecera antes e iria se repetir depois, as forças oposicionistas mais agressivas avançaram sem arrastar consigo o resto da oposição; ao mesmo tempo, porém - e aqui está a sutileza - contaram com a sua simpatia ou, pelo menos, com a sua complacência. Embora os emedebistas temessem a reação militar que as atividades da Frente poderiam suscitar, a opção oficial do partido (21 de setembro) foi a de não se indispor com os parlamentares frentistas e com as parcelas radicalizadas da opinião pública.

A existência e o desenvolvimento da Frente contribuíram para aguçar a combatividade do movimento estudantil que já optara, com a campanha do voto nulo em 66, pelos métodos não-convencionais de luta política. Mas a fagulha que ateou fogo à floresta ressequida 
por tantos anos de exclusão foi a morte do estudante Edson Luís, em 28 de março de 68, no Rio de Janeiro, num choque entre a Polícia Militar e estudantes que simplesmente reivindicavam a melhoria de um restaurante. A partir daí deflagra-se a crise que irá culminar com a edição do AI-5, em 13 de dezembro.

Não é possível relatar em poucas palavras a variedade, a quantidade e a intensidade das lutas travadas durante aqueles nove meses nos principais centros urbanos do país. Os estudantes (universitários e secundaristas) constituíram sem dúvida a vanguarda do movimento de contestação que se manifestou na forma de greves (localizadas e nacionais), comícios (organizados ou relâmpagos), passeatas (isoladas ou apoiadas pela população), choques violentos com as forças repressivas (em conflitos de rua ou invasões de escolas). A simpatia da população, o apoio da Igreja, da intelectualidade e do MDB, a influência da rebelião de maio na França, a revolta gerada pela truculência das ações policiais, tudo contribuía para que a agitação estudantil batesse às portas do mundo do trabalho. Em 22 de abril eclodiria em Minas a primeira greve operária de grande vulto desde 64 , com a paralisação de cerca de sete mil trabalhadores. Em meados de julho, seria a vez de São Paulo parar, com a famosa greve de Osasco. Em setembro, houve novas ameaças de greve em Minas, seguidas de outras, no Rio, por parte dos bancários. No mesmo mês de setembro, os ministros militares representam junto ao presidente da República contra os discursos pronunciados pelo deputado Márcio Moreira Alves, considerados ofensivos à honra das Forças Armadas. Antes e depois, sucederam-se as manifestações de temor por parte das lideranças empresariais, assim como os estados de prontidão da tropa e as reuniões de emergência do Alto Comando e do Conselho de Segurança Nacional. Em novembro, o arcebispo de Olinda, D. Helder Câmara, lança no Nordeste o movimento "Ação, Justiça e Paz", organizado para lutar contra as estruturas arcaicas entre as quais se incluíam a educacional e a trabalhista (que estavam na ordem do dia) e se acrescentava, como novidade, a agrária. Bombas de verdade, mas isoladas e esparsas, já haviam explodido em vários pontos do país. Agora, porém, no dia 10 de novembro, a imprensa noticiava que o dissidente comunista, Carlos Marighela, tinha sido apontado como chefe do grupo responsável por vários assaltos a bancos. Um mês depois a Câmara dos Deputados montava uma Comissão Parlamentar de Inquérito para investigar atos terroristas em todo o país.

Nesse clima é que se chegou â etapa final do caso Marcio Moreira Alves. Em novembro nove representantes da Arena tiveram de ser substituídos a fim de que a autorização para processar o deputado pudesse passar na Comissão de Justiça. A rebeldia instalara-se também no Congresso e no partido do governo. A 13 de dezembro o Executivo foi derrotado em plenário pela diferença de 75 votos. No fim do dia estava suspensa a Constituição de 67 e editado o AI-5.

Abria-se, assim, a nova conjuntura que seria presidida pela luta armada. A guerrilha, no entanto, não fora descoberta no ano de 69. 
Desde o princípio da década de 60 a ideia de reproduzir a Revolução Cubana havia conquistado adeptos por toda a América Latina. Uma vez instalada, porém, ela seguiria em cada país um trajeto próprio, condicionado pelos processos políticos nacionais (na Venezuela, a guerrilha eclodiria quase que de imediato; na Argentina, seria um fenômeno dos anos 70). Assim sendo, a chave para entender o momentâneo êxito da proposta de luta armada no Brasil não deve ser buscada nos seus méritos próprios - que eram parcos, aliás - mas na crise do movimento progressita derrotado em 64.

De fato, o golpe determinou a débâcle das direções políticas tradicionais (do PCB e do PTB), cuja ascendência sobre o movimento de massas e as organizações da sociedade civil entrou em franco declínio ao mesmo tempo que a crítica ao populismo se difundia e se enraizava. Denunciava-se não tanto a ocorrência do golpe, mas a desmoralizante ausência de resistência, o grau extremo de fragilidade a que se haviam condenado as forças que se julgavam a um passo da conquista definitiva do poder e que, no entanto, foram colhidas de surpresa por um golpe, além de tudo perfeitamente previsível, capaz de em poucas horas jogar por terra o decantado "dispositivo militar" de Jango e a grande aliança progressista que excluía apenas a pequena minoria formada por latifundiários e testasde-ferro do imperialismo. A fortaleza ruíra ao primeiro sopro porque fora construída sobre ilusões de classe.

Seja como for, as lideranças tradicionais perderam o pé. Sem mártires sem heróis, sem vínculos orgânicos com a sociedade, não tinham meios sequer de se fazerem ouvidos. A descontinuidade se impôs. A crítica assumiu o lugar da autocrítica e passou a comandar o debate, retirando de seu repertório os critérios a partir dos quais distribuiu as responsabilidades pela derrota, formulou as denúncias (contra o reformismo, contra o reboquismo, contra o cupulismo) e apontou os novos objetivos e métodos a serem adotados.

E um equívoco supor que a luta armada foi suscitada pelo AI5, como simples reação a uma ação. Bem antes do AI-5, a repulsa frontal à ordem de coisas vigente já tinha se difundido nos círculos oposicionistas de esquerda. Quanto mais a passagem dos anos foi patenteando a persistência da intervenção militar, tanto mais a ideia de contestação se tornava a única a fazer sentido. A memória oposicionista recordava apenas os picos autoritários da história recente, enquanto que, por sua vez, a direita ressaltava a continuidade da Revolução "que não era, mas é e será". O quadro resultante sublinhava a permanência no poder de uma coalizão reacionária, simbolizada pelo governo militar que, tendo entrado e ficado pela força, só sairia pela força, independentemente do regime. Tal representação só desmoronaria a posteriori, mediante a prova da formidável desproporção existente entre as forças confrontadas.

Até lá - e especialmente a partir de 67, quando a crise da sucessão e a posse de um novo general confirmam a imagem da usurpação que se auto-eterniza - a ideia de contestação tende a se tornar a principal fonte de sentido, de esperança e de mobilização. De fato, era dela que provinha o tipo de repúdio que se manifestava nas 
artes, nos palcos e nos festivais, assim como a extravasante insubordinação que aparecia nas ruas, nas escolas e nas greves. A ideia revolucionária estava presente em quase todas as lutas e, acima de tudo, impulsionava a atuação do movimento estudantil como destacamento avançado do protesto das classes médias. As escaramuças com a polícia não se limitavam em si mesmas: significavam um prelúdio, um primeiro exercício da violência justa que, já contando com as bênçãos da Igreja e os auspícios da intelectualidade, haveria de comover a classe operária e derrotaria, em breve, a violência injusta. Esse era o mote glosado nas assembléias estudantis e nos congressos da UNE. Essa era a novidade que dava o tom e o ritmo característico dos comícios da época: "Eles podem fazer 1, 2, 3 , 4 Congressos de araque; podem botar 1, 2, 3, 4 governadores fantoches; podem criar 1, 2, 3, 4 Exércitos de esbirros. Nós vamos derrubar 1, 2, 3, 4 Congressos de araque; vamos derrubar 1, 2, 3,4" e assim por diante. A redundância afirmava a disposição de lutar até o fim, demolindo o que aparecesse, fosse o que fosse. Mais do que isso, cuidava-se evidentemente de canalizar o caudal de protesto para as organizações que se lançariam mais adiante ao confronto militar.

De fato, a perspectiva de luta armada era um elemento integrante dos movimentos de massa daquele período. Era de conhecimento geral que as vanguardas já haviam feito sua opção. Num manifesto curiosamente publicado por um órgão da grande imprensa - o Jornal do Brasil - Carlos Marighela preconizava a guerrilha como a única iniciativa válida naquela conjuntura. O objetivo imediato seria o de transformar a crise política reinante em conflito militar generalizado, ou seja, em guerra civil. Graças às ações a serem empreendidas pelos guerrilheiros, dizia Marighela, "o poder se verá forçado a transformar a situação política do país em situação militar. Isso descontentará as massas que, a partir de então, se revoltarão contra a polícia e o exército (...) Os lares serão violados, inocentes serão presos, as vias de comunicação serão fechadas. O terror policial se instalará e (...) dessa forma, os guerrilheiros obterão o apoio das massas e destituirão a ditadura" ${ }^{\text {"15 }}$ A data da publicação — setembro de 68 — é tão significativa quanto o seu conteúdo.

Não havia dúvida (nem na oposição, nem no governo) de que a perspectiva de luta armada estada presente. Em grande medida, isso é o que explica a diferença flagrante entre o comportamento oposicionista de então e o de agora. Comparativamente, vemos que hoje a oposição é bastante bem-comportada: contida, no que diz e no que faz, ela avança nos espaços deixados abertos pelo poder, procurando expandi-los apenas incrementalmente. "Ocupar os espaços", "forçar os limites do possível", assim se expressa a sua sabedoria. Em 67-68, ao contrário, valorizava-se o exercício da insurgência, a invasão dos espaços vedados, a ação que ignorava limites.

O AI-5 não visou a luta armada em particular. Mais do que tudo, o que atemorizava o governo era a desestabilização, a

15 Jornal do Brasil. 
incapacidade de se manter face ao alastramento do clima de sublevação. Em fins de 68 não se tratava ainda de abater um inimigo preciso, bem identificado, que desafia o poder nos seus próprios termos, isto é, no plano político-militar. O escopo do cometimento governamental era mais amplo: tratava-se de debelar a contestação difusa, domesticar vastos setores da sociedade, neutralizar áreas nevrálgicas da opinião pública. Com o AI-5, instaurou-se o controle absoluto.

O regime mudara de novo e, desta vez, para bastante pior. Passara a ser o que nunca dantes havia sido. As oposições, que tanto tinham falado de ditadura, viam-se agora diante de uma Ditadura com "D" maiúsculo. Para começar, o novo instrumento de poder por meio do qual se institucionalizava $\mathrm{O}$ arbítrio não tinha data prefixada para deixar de existir. Simplesmente abolia, por prazo indeterminado, os limites constitucionais antepostos à ação governamental. Dali para diante, o presidente passava a ter à sua disposição um formidável arsenal de poderes excepcionais, ficando autorizado a: 1) decretar o recesso do Congresso e demais casas legislativas; 2) decretar intervenções em estados e municípios; 3) cassar mandatos eletivos e suspender direitos políticos de qualquer cidadão; 4)remover, aposentar ou reformar quaisquer titulares de cargos públicos; 5) decretar o estado de sítio e fixar seu prazo de duração; 6) decretar o confisco de bens; 7) suspender garantias constitucionais referentes às liberdades de reunião e de associação; 8) estabelecer a censura da imprensa, da correspondência, das telecomunicações e das diversões públicas.

A repressão abateu-se sobre o país, atingindo pessoas e instituições. O Congresso foi posto em recesso. Quatro senadores e noventa e cinco deputados tiveram seus mandatos cassados. O MDB perdeu 40 por cento de seus parlamentares. Cinco juízes do Supremo Tribunal Federal e um do Supremo Tribunal Militar foram aposentados. Cerca de quinhentas pessoas que ocupavam posições de relevo na vida social do país (professores universitários, jornalistas, militares, diplomatas) perderam seus direitos políticos, bem como aquelas posições que lhes permitiam influir na formação da opinião pública. Os delegados da censura instalaram-se nas redações dos jornais, nas emissoras de rádio e televisão, nas casas de espetáculo. As forças policiais e os serviços secretos passaram a atuar de forma desabrida e totalmente irresponsável, violando a privacidade dos lares, da correspondência e das comunicações, cerceando discricionariamente o exercício de todas as liberdades públicas. As detenções assumiram o caráter de seqüestros e se multiplicaram em ondas sucessivas. Todo cidadão, independentemente de classe, raça ou credo, tornara-se em princípio suspeito da prática de delitos contra a segurança nacional. A repressão abolira tudo, inclusive as discriminações sócio-culturais.

Conseqüentemente, 69 e 70 foram anos em que a luta oposicionista se reduziu à faixa extremamente exígua ocupada pelas ações guerrilheiras e as atividades complementares de apoio logístico, advocacia penal, denúncias no exterior e assistência às 
famllias. Pari passu, prosseguia o processo de aprofundamento do autoritarismo. O AI-5 assinalara apenas o começo da mudança do regime. À medida que se verificava a escalada da violência — com a multiplicação dos focos guerrilheiros, dos seqüestros de diplomatas, dos assaltos a bancos e dos choques com guarnições militares novos instrumentos foram sendo criados para aumentar ainda mais o conjunto de poderes autocráticos do governo mil.

Em fevereiro de 69 foi editado o AI-6, que atingia diretamente o Poder Judiciário, alterando a composição do Supremo Tribunal Federal e retirando-lhe a competência para julgar, em grau de recurso, as decisões proferidas pela Justiça Militar no julgamento de civis. Ainda em fevereiro, o AI-7 suspende a realização das eleições parciais para cargos executivos e legislativos. Em maio, o AI-I O estabelece penalidades acessórias para os atingidos pelos Atos Institucionais, em acréscimo às sanções determinadas por aqueles Atos. Em agosto, o AI-11 prorroga o mandato de prefeitos e vereadores ao mesmo tempo que, com base no AI-12, a Junta Militar autodesignada afasta o substituto constitucional do presidente da República e assume o poder por conta própria. Em setembro, a Junta baixa o AI-13 e o AI-14: o primeiro autoriza o banimento de qualquer cidadão brasileiro considerado nocivo â segurança nacional; o segundo introduz a pena de morte. Em outubro, o AI-17 faculta a transferência para a reserva de militares que viessem a atentar contra a coesão das Forças Armadas. Visava-se com isso coibir os oficiais descontentes que porventura opusessem resistência ao endurecimento do regime e, em especial, tratava-se de desarticular o "partido fardado" (a direita nacionalista liderada por Albuquerque Lima), cujas pretensões â hegemonia tinham então — atingido o auge.

A lista dos instrumentos de exceção criados no período inclui ainda cerca de cem Atos Complementares, editados para fins de execução dos Atos Institucionais. Ademais, cumpre recordar que a peculiaridade dos Atos consistia em que as medidas tomadas com base nos seus dispositivos, bem como os efeitos gerados por tais medidas, ficavam excluídos de apreciação judicial.

O fortalecimento autocrático do Estado prosseguiu com a Emenda Constitucional n. 1, de outubro de 69, impropriamente chamada de Constituição de 69. Essa emenda foi promulgada pela Junta Militar durante o recesso do Congresso. Ela acentua ainda mais a preocupação com a defesa do Estado que a Carta de 67 havia introduzido e o desenvolvimento da luta armada estava justificando. A tendência que assim se reforçava fazia com que "o princípio de segurança nacional se tornasse verdadeira norma fundamental do sistema constitucional vigente, espécie de princípio de necessidade, sobre pairando sobre a eficácia de quase todas as normas constitucionais". Observe-se, além disso, que o conceito de segurança nacional, em nome do qual a nova Carta estabelecia inúmeras disposições restritivas (como a perda da imunidade parlamentar), não é definido no texto da Constituição.

O avanço da prepotência não parou aí. Em janeiro de 69 foi baixado o Decreto-Lei ${ }^{\circ} 9471$ que punia com rigorosas penalidades, 
aplicada sumariamente, os professores, alunos e funcionários de qualquer estabelecimento de ensino que viessem a participar de atividades tidas arbitrariamente pelo governo como atentatórias à ordem pública. Em setembro, a Junta promulgou uma nova Lei de Segurança Nacional sob a forma do Decreto-Lei 898, que duplicava o número de artigos constantes na legislação anterior. Entre os novos dispositivos introduzidos, destacavam-se os que tinham por objetivo combater a luta armada: seqüestros, assassinatos políticos, assaltos a instituições financeiras e atos de terrorismo em geral. Outra contribuição da nova lei foi o agravamento das penas privativas da liberdade.

Em outubro foram editados mais dois decretos referentes à luta armada e um terceiro que tomava passíveis de expulsão os estrangeiros considerados perigosos. Como se o resto fosse pouco, foi explicitamente abolido, com a legalização dos decretos secretos em novembro de 71 , o princípio da publicidade dos atos normativos realizados pelo governo.

Todavia, a análise da dimensão jurídico-institucional não consegue captar a realidade do autocratismo em toda a sua brutalidade. Para completar o quadro seria necessário examinar, com riqueza de detalhes, tudo que se passou no campo efetivo das práticas repressivas. Aí, sim, é que se pode ver até que ponto os órgãos de segurança constituíram-se como uma verdadeira "força autônoma", situada acima da própria ordem autoritária e poderosa o suficiente para perseguir, seqüestrar, torturar e assassinar sem ter de prestar contas de seus atos a ninguém.

Por outro lado, a história do período demonstrou que nada podia ser mais infundado do que o prognóstico feito por Marighela (e tantos outros) em 1967. Com o aumento da repressão, as massas não aderiram à sublevação armada. Em lugar de dar corpo aos arroubos do subjetivismo revolucionário, a população se amedrontou e se afastou da vida pública. Com o "milagre econômico" correndo em paralelo às atividades revolucionárias, o presidente Médici chegou a alcançar elevado índice de popularidade e o partido do governo - a reacionária e fisiológica ARENA saiu-se sobejamente vitorioso nas eleições gerais de 1970 .

Com a posse de Médici completa-se o processo de rearticulação interna da coalizão dominante, processo que se iniciara em fins de 65 com a edição do AI-2. Referido a esse fato, surge em 69 o termo "sistema", até então inusitado no vocabulário político corrente. A introdução daquela novidade terminológica correspondia à necessidade de designar uma realidade que, tendo acabado de emergir, ainda não tinha um nome. O novo pacto - ou, mais precisamente, a nova estrutura de poder que estabelecia as relações entre os setores componentes da coalizão dominante passou a ser chamado de "o sistema". O esquema hierárquico implantado em 64 foi derrubado e substituído por uma divisão horizontal e (até certo ponto) funcional do poder. A nova estrutura desmonopolizava a função de direção política, entregando-a a uma espécie de colegiado. A Junta, cuja presidência era exercida por rodízio entre os três 
ministros militares, foi a primeira materialização desse novo acordo.

A evolução que produziu o "sistema" não se processou de modo linear. Antes de ter sido alcançado o ponto de equilíbrio (coroado com a solução Médici) verificou-se a turbulenta irrupção dos "jovens turcos" da direita nacionalista. Conforme foi observado por Oliveiros Ferreira, a morte de Costa e Silva em simultaneidade com a intensificação da luta armada "foi a grande oportunidade estratégica aproveitada pelos ministros militares para restabelecer seu controle sobre a tropa e impedir o triunfo do 'partido fardado"'. Como a posse de Costa e Silva tinha sepultado as pretensões da Sorbonne, os nacionalistas de direita, conhecendo a congênita inaptidão da linha dura para o exercício do governo propriamente dito, superestimaram suas próprias chances e passaram a disputar o comando supremo da coalizão que então dividiam com os burocratas e os duros. O impedimento e a morte do presidente colocaram ao alcance de suas mãos o troféu que seria agarrado não fosse a pronta intervenção da Junta.

Falando em nome da coesão das Forças Armadas e atuando energicamente, a Junta conteve o movimento ascensional dos "jovens turcos" e acabou encontrando no apartidarismo de Mediei a fórmula adequada para selar um novo arranjo que a todos contentasse. O acordo final, presidido por Médici, concederia aos principais atores um espaço proporcional ao peso específico de cada qual. Ao mesmo tempo negaria a cada um em particular o direito de supremacia sobre os demais.
O "sistema" representa, em suma, a conciliação finalmente lograda entre os interesses dominantes. O novo termo destacava justamente a ideia de unidade entre elementos distintos, mas não em luta; partes diferenciadas de um mesmo todo, recompensadas de modo a funcionar em mútua colaboração. O advento do "sistema" refazia a coesão das forças situacionistas e consagrava a predominância da solidariedade sobre os conflitos intestinos, lesivos à preservação do bloco no poder. Em termos sócio-econômicos, o "sistema" significava garantia de inserção no 'Estado para todas as frações das classes dominantes, fosse qual fosse, positiva ou negativa, sua contribuição para o processo de desenvolvimento nacional. $\mathrm{O}$ compromisso não excluía ninguém: ia do latifúndio às multinacionais, passando por todas as modalidades de exploração do homem pelo homem, desde as mais modernas até às mais retrógradas, incluindo as que são contrárias aos interesses da produção. O custo seria pago mediante o arrocho salarial, garantido pelo sindicalismo corporativista, a inflação e o endividamento interno e externo.

Do ponto de vista orgânico, o "sistema" comportava uma funda diferenciação estrutural, em termos da qual definia-se uma nítida divisão de tarefas: de um lado, o aparelho administrativo do Estado, encarregado da formulação e da gestão das políticas econômica e social, que era unificado, pela cúpula, por um órgão colegiado — o CMN, Conselho Monetário Nacional — sob o comando do todopoderoso czar da economia, o ministro da Fazenda Delfin Netto. Esse 
organismo constituía o locus privilegiado de barganha e negociação, onde as demandas das diversas frações do capital eram filtradas, hierarquizadas e. diferencialmente contempladas pela política estatal. ${ }^{16}$ De outro lado, os temas políticos, afetos à área de segurança nacional, eram processados em agências específicas, no interior de uma rede que tinha como pontos focais o SNI - Serviço Nacional de Informações - e o Conselho de Segurança Nacional, ambas instâncias integralmente militarizadas. A mediação entre esses dois segmentos do aparelho de Estado parece ter sido efetuada pela chefia da Casa Civil, na pessoa do ministro Leitão de Abreu, que se desincumbia também do trato com o "pessoal político do regime" os quadros do partido oficial, a ARENA - e dos governos estaduais.

Surgindo, em outubro de 69 , como solução intermediária para a crise militar mais grave jamais conhecida pelo regime, já em meados do ano seguinte o governo Médici havia vencido as últimas resistências internas, havia cimentado as suas bases de apoio e começava a colher os dividendos políticos dos repetidos sucessos que, a partir de então, passaram a se acumular.

Tendo por base as reformas institucionais realizadas pelos governos Castello e Costa e Silva, beneficiada pelas condições excepcionalmente favoráveis do mercado mundial, a economia

16 Cf. Celso Lafer, O Sistel1lil Político Brasileiro, São Paulo, Editora Perspectiva, 1975; Maria Lúcia Teixeira Werneck Vianna, A Administração do "Milagre"; O Conselho Monetário Nacional - 1964/1974, tese de Mestrado defendida no IUPERJ, 1982. brasileira segue em sua inflexão ascendente, expandindo-se a taxas espetaculares: 8,8\% em 1970; 13,3\% em 1971; 11,7\% em 1972; $14 \%$ em 1973. Na cadência vertiginosa das cifras, um clima de incontida euforia toma conta do país oficial e o regime chega a acalentar o sonho de se legitimar com base na excelência de seu desempenho nos números indicativos de seus reiterados sucessos. Nessa época de quase total recesso político as seções econômicas dos grandes jornais ganham em espaço e densidade. Durante alguns anos, o índice de crescimento do PIB é elevado à condição de tema palpitante, ocupando manchetes e dividindo com o noticiário esportivo o apelo à atenção do público em geral. O Brasil, que numa explosão de alegria havia conquistado o título de tricampeão mundial de futebol na Copa do México, estava ganhando igualmente o troféu do desenvolvimento. "São 90 milhões em ação, pra frente Brasil, salve a seleção..." - essa marchinha, de autores anódinos, fora transformada no hino oficioso do Brasil de Médici, e ao assumir essa nova qualidade, o significado de sua letra sofria uma mudança sutil, e a seleção éramos todos nós, 90 milhões, homens e mulheres, trabalhando em comum na construção do futuro em que o Brasil realizaria enfim o seu destino de grandeza e glória.

1970-73: inspirada nos princípios da guerra psicossocial, a propaganda do governo, difundida nacionalmente pela AERP Assessoria Especial de Relações Públicas da Presidência da República — bombardeava permanentemente a população com a mística do "Brasil Grande", com as evidências dos progressos 
alcançados e o apelo agressivo dos projetos impacto, procurando explorar ao máximo o efeito ideológico das políticas sociais (PASEP, PRORURAL, FUNRURAL, PROTERRA) e da grandiosidade de alguns empreendimentos, dos quais o da Transamazônica provavelmente terá sido o mais desastrado.

Um país forte, dinâmico, seguro, em paz consigo mesmo. Essa a fachada que o regime procurava exibir, sobretudo para efeito de consumo interno. No exterior, ao mesmo tempo que combatia as sucessivas "campanhas de difamação levadas a efeito pela subversão internacional", avançava argumentos de outra natureza, incomparavelmente mais sólidos, mais persuasivos: "a ordem interna está garantida e melhores condições de lucratividade não há".

Sob a capa da ordem, protegida da curiosidade pública pelos rigores de uma censura estúpida, mas onipresente, lavrava a guerra suja contra os grupos de esquerda que haviam optado pela luta armada; estava a tortura, erigida, então, em uma prática institucional a qual se repudiava publicamente mas se aceitava de fato, em nome dos imperativos maiores da Razão de Estado; multiplicavam-se os assassinatos (morte "por atropelamento", "em combate", "em tentativa de fuga", na linguagem torta dos comunicados oficiais), bem como os seqüestros, que atingiam igualmente os militantes da referida esquerda e figuras da oposição legal ou semilegal; desenvolvia-se um exercício sistemático de intimidação, que recorria a métodos policiais (detenção, interrogatório, seguidos de ameaças, na ausência de qualquer acusação específica), administrativos (exigência de atestados de bons antecedentes políticos para a obtenção de documentos, para acesso a cargos públicos etc.), econômicos (pressões sobre o empregador para que demitisse o funcionário com "ficha suja") e se estendia, no plano simbólico, ao terrorismo branco de oficiais paranóicos que enchiam as páginas dos mais importantes jornais do país com proclamações fantásticas onde a "liberdade sexual", o consumo de drogas e as opiniões políticas menos ortodoxas se fundiam como facetas da estratégia bolchevista para destruir a família, a harmonia social e a paz política. Subjacente à ordem, imperava o medo.

Nunca, como nesses anos, o país esteve tão próximo da imagem ideal que dele fazia a extrema-direita. Próximo, dissemos, e é importante sublinhar este adjetivo. Porque, mesmo então, não se chegou no Brasil a instaurar uma ordem política acabadamente autoritária, dotada de instituições e de um corpo doutrinário coerentes, que dessem suporte à sua ambição de projetar-se indefinidamente no tempo. Apesar das limitações incríveis a que esteve sujeito, não obstante a coação sistemática, as ameaças, o controle cerrado sobre suas atividades, o Congresso estava em funcionamento desde outubro de 1969, quando foi reaberto depois de um recesso que se prolongou por dez meses. Poupado, também, foi o "partido da oposição": embora severamente desfalcado pelos sucessivos expurgos, quase esmagado pelas restrições impostas pela censura e todo o peso da máquina publicitária do governo, o MDB sobreviveu às propostas de auto dissolução que intermitentemente 
brotavam em seu solo e, sob a impulsão de seus setores mais avançados, pouco a pouco foi definindo uma fisionomia própria e ganhando alguma credibilidade.

"Reitero que todo o brasileiro tem direito de fazer oposição ao Governo, considero imprescindível ao bom funcionamento do regime a existência de opositores. Por isso mesmo não serei hostil aos que de mim discordarem. No meu Governo não haverá coação por motivos puramente políticos." Assim falava Mediei ao dirigir sua mensagem à nação, no início de 1970. Antes disso, ao tomar posse como presidente, ele prometera deixar, ao término de seu mandato, "definitivamente instaurada a democracia em nosso país". Sabemos que essas palavras perderam-se no ar, mas nem por isso devemos menosprezá-las. Com efeito, elas se adicionam como uma evidência a mais da tensão interna que permeia todo o período e que se expressa na disjuntiva: buscar a "normalidade política" mediante a recomposição da ordem constitucional fraturada em 68 ou na tentativa de fundar em princípios outros que não os da legitimidade liberal a arquitetura de um Estado renovado.

Mantido o quadro de indefinição, para muitos uma coisa pareci, certa: a situação. vigente, em que a "ordem institucional" sobrepunha-se à "ordem constitucional" numa convivência precária e embaraçosa, essa situação era menos do que satisfatória. Por um lado, ela contaminava o processo político com um grau Pouco. tranquiilizador de imprevisibilidade por outro., deixava pendente uma série de problemas, dentre os quais o da sucessão era o mais angustiante, como a memória dos acontecimento: de agosto-outubro de 69 - a crise deflagrada pela doença e inabilitação de Costa e Silva - claramente indicava. Assim, não admira o fato de que cedo se tenham feito ouvir, nos meios governistas, vozes advertindo sobre a necessidade de dar tratamento adequado à questão político institucional Milton Campos, Herbert Levy, Petrônio. Portella, Magalhães Pinto, entre outros, manifestaram-se nesse sentido ao longo dos anos 70 e 71, em alguma medida fazendo coro com os parlamentares do MDB que não cansavam de bater nessa mesma tecla.

De fato., juntamente com o. tema da distribuição de renda, guindado (ao primeiro plano das atenções pela divulgação dos resultados do censo (de 70, a questão do "modelo político" comparece como um dos ponto permanentes na agenda do debate público. que se trava no período Médici recebendo estímulos que pro.vinham dos setores "liberais" da vida: nacional, da Igreja, da grande imprensa, da judicatura, da intelectualidade ele solicita a atenção. do.s político.s e chega a alcançar os círculos militares — em 1971, ao assumir o comando da ESG, o. general Rodrigo Octavio Jordão Ramos pronuncia-se a favor da normalização institucional e trado problema à consideração da Escola. No entanto, é a partir de 1972, no compasso das articulações que preparavam a sucessão de Médici e da especulações por elas geradas, que a discussão. em torno das medida requeridas para a plena configuração do "modelo político" ganha maio intensidade, passando. a ser assumida quase que 
ostensivamente aparelho governamental.

É desta época o comentário que transcrevemos a seguir, pelo que ele tem de ilustrativo daquela atmosfera. "No seio do governo, o tema descompressão continua a ser estudado, ainda que sem perspectiva d ser aplicado imediatamente. Recentemente um trabalho do professo. Manoel Ferreira, ex-secretário do Ministério da Justiça, tentou penetra no segredo da esfinge: deveria o AI-5 ser revogado. Gradual ou inteiramente? (...) Tudo leva a crer que persiste dentro do governo um orientação antigradualista, prevalecendo o pensamento de que quando. AI-5 for objeto de revogação, isso virá como uma decisão abrangente todo o seu texto, e não apenas uma de suas partes. O bom entendedor poderá deduzir que o AI-5 ficará em vigor até 1974, pelo menos. (grife nossos) ${ }^{17}$ Com a perspectiva temporal que a história concede, o que ressalta nessa análise não é tanto a exatidão de seu balanço, mas o otimismo disfarçado de seu prognóstico "até 74 conviveremos com o Ato". E essa não era uma opinião isolada: levantamento realizado na ocasião ${ }^{18}$ constata nitidamente a expectativa generalizada de que as mudanças liberalizantes viriam com o novo governo, o otimismo sendo maior entre jornalistas, que, dessa forma, se destacavam da visão algo mais sombria dos "cientistas políticos" e/ou sociólogos.

Em junho de 1973, Médici anuncia o nome do general Ernesto

17 "Tudo igual até 1974?", Revista Vislfo, 15.1.1973.

18 Wanderley G. dos Santos e Isabel R. O. Gomes de Souza, Abertura Política: antecipações e estimativas, Rio de Janeiro, IUPERJ, 1973.
Geisel como futuro presidente do país, pondo fim, oficialmente, ao processo sucessório mais fechado e aparentemente menos traumático dos quatro ocorridos na história do regime. Nesta condição, mas ainda vestido na fantasia de candidato da ARENA, este mantém-se em silêncio, deixando livre o espaço para que se especulasse à vontade sobre as diretrizes que imprimiria a seu governo. Dois temas apareciam, então, como objetos recorrentes de preocupação nos comentários: a continuidade da política econômica e as perspectivas de mudanças institucionais. Somente a partir de janeiro, depois de ter a sua indicação homologada pelo Congresso, Geisel toma públicos os nomes dos principais integrantes de sua equipe e começa a estabelecer contato com figuras representativas da vida nacional, externando suas intenções e cuidando de costurar o suporte político para o seu governo. Durante dois meses, informações sobre o conteúdo dessas gestões foram sendo filtradas e, embora parcas, o resultado do exame exaustivo e por vezes bizantino a que eram submetidas na imprensa e na intimidade dos gabinetes parecia encorajador: o momento da distensão finalmente havia chegado. Assim, ao pronunciar o longo discurso programático na abertura da primeira reunião de seu Ministério, quando Geisel fere a problemática do regime, apelando à "imaginação política criadora" para que venham a ser superados os instrumentos de exceção em vigor, suas palavras soam como a comprovação esperada do acerto de um juízo previamente formulado.

Esse discurso, de 19.3.74, é extremamente significativo, 
porque num único parágrafo condensa os elementos centrais do dispositivo estratégico que iria balizar toda a atuação do governo Geisel na área política. Com efeito, lá está claramente afirmada a norma da máxima prudência, o gradualismo que caracteriza o seu projeto: prefiro ver os instrumentos excepcionais "não tanto em exercício duradouro, ou freqüente, antes como potencial de ação repressiva ou de contenção mais enérgica". Ao contrário do que se chegou a imaginar, o AI-5 e todo o cortejo da legislação excepcional não seriam pura e simplesmente suprimidos. Eles perderiam sua vigência na prática, desfaleceriam, aos poucos, pelo desuso, mas continuariam presentes como reserva de poder ilimitado a ser ativado, sem que daí adviessem traumas maiores, sempre que as circunstâncias o aconselhassem. O contraste com o intento de Castello de assegurar a normalidade política pela outorga de uma nova Constituição não poderia ser mais gritante. Com Geisel, as regras formais, as disposições escritas perdem muito de sua aura; na sua gestão, todo privilégio é concedido às normas efetivamente operativas no comportamento político dos atores, que devem aprender a se movimentar num campo onde predomina o tácito, o subentendido, o que está implícito em cada mensagem. De outra parte, à diferença do que se fez no passado, agora não se estipulam metas, nenhum compromisso é estabelecido. Geisel nada promete: a normalidade institucional é uma aspiração do governo, que espera vêla realizada no futuro. E é tudo. Prazos não são definidos.

Definidos, sim, são os limites da situação almejada: os instrumentos de exceção permanecem como recursos virtuais "até que sejam superados pela imaginação política criadora, capaz de instituir, quando for oportuno, salvaguardas eficazes dentro do contexto constitucional'. Em outro sentido, portanto, não se trata exatamente de abolir tais instrumentos. Na hora oportuna eles deverão mudar de forma, dando lugar, no próprio texto da Constituição, a mecanismos passíveis de cumprir, com igual ou maior eficácia, idênticas funções. Não se pensa num retomo ao estado de coisas passado, não se acena com a perspectiva de anistia, eleições diretas, alternância de poder ou qualquer outro item que pudesse indicar a democracia como alvo. A normalização que se pretende é da "ordem revolucionária". Mais do que um programa de transição, o que se esboça nas palavras de Geisel é um projeto de institucionalização do regime autoritário, que prevê medidas liberalizantes, mas apenas na medida em que sirvam a esse propósito.

Mudança de forma. Tal é a intenção declarada. Mas ela não é incondicional: o aperfeiçoamento "não depende tão-somente da vontade do Poder Executivo federal, pois reclama, em larga medida, colaboração mais sincera e efetiva dos outros poderes da nação "... e dependerá necessariamente de que o espírito de contestação de minorias trôpegas ou transviadas... acabe por exaurir-se ante o repúdio geral". A liberalização não se coloca como uma iniciativa unilateral do poder, ao contrário, ela é proposta como uma ação transitiva que envolve e deve comprometer, necessariamente, os demais poderes do Estado e as principais forças do campo 
oposicionista, o seu sucesso — e mesmo a sua continuidade ficando na dependência de que seja efetivamente batido "o espírito de contestação de minorias trôpegas ou transviadas", vale dizer, que sejam isolados aqueles que ainda insistam em questionar a autoridade constituída.

Se acrescentarmos a referência aos "revolucionários sinceros, mas radicais" — que ficará para mais tarde um pouco — temos aí todos os elementos da assim chamada estratégia da distensão — uma proposta de liberalização gradual e limitada, cujo tempo e direção o próprio governo se encarregaria de fixar.

Excluídos aqueles que se recusaram a admitir a novidade dessa postura e foram, logo a seguir, surpreendidos pela marcha dos acontecimentos, desde então discutiu-se muito sobre a razão de ser desse passo: a decisão de abrir, em algum grau, o regime. Não se deveria perder de vista, entretanto, o contexto mais geral em que essa decisão é tomada. Na verdade, ao que tudo indicava, ele não poderia ser mais favorável.

$\mathrm{Na}$ frente interna do regime saía de uma sucessão não contestada, e a polarização de tendências nas Forças Armadas, que em períodos anteriores havia conduzido a crises agudas e ameaçadoras, aparentemente ficara para trás, vencida que fora pela afirmação dos princípios institucionais de hierarquia e autoridade (por paradoxal que possa parecer, é no momento em que a militarização do Estado atinge o ápice que maior é o esforço para despolitizar o Exército).
No que tange à oposição oficial — o MDB — ela acabara de sofrer uma derrota tão pesada nas últimas eleições parlamentares que muitos chegaram a duvidar de sua capacidade de sobreviver ao cerco fechado a ela imposto pelo regime (nessa ocasião, circula mais uma vez no partido a tese da autodissolução). Por outro lado, essa oposição conhecera uma mudança sensível no seu discurso e no estilo de sua atuação: se antes de 68 contestava o regime, fazia tabula rasa de suas interdições, escalava no radicalismo da linguagem, nos anos Médici ela se notabiliza pela moderação, pela sensibilidade apurada na percepção do estado de ânimo mutável das Forças Armadas, pela busca de caminhos a trilhar nas brechas apresentadas nas estruturas e nas práticas do próprio sistema. Tendo anulado o ato reflexo de rejeição, o autoritarismo acabara por moldar uma oposição acorde ao seu feitio. Avara na assunção de riscos, adiando para um futuro longínquo a consecução de objetivos mais ambiciosos, atendo-se à defesa dos direitos humanos, à reivindicação das liberdades formais e da normalização institucional, o MDB chega a ganhar alguns pontos, mas nem de longe poderia ser visto como ameaça à estabilidade da ordem política estabelecida.

Quanto à oposição não institucional, àquele momento as organizações de esquerda que optaram pela luta armada já haviam sido batidas e estavam quase todas desarticuladas, com os seus militantes — os que conseguiram sobreviver — vegetando nos cárceres do regime, no exilio ou amargando no país a triste condição de emigrados internos. A esquerda tradicional - o PCB - tendo 
sofrido algumas perdas importantes, estava sob controle e tampouco representava risco mais sério.

No entanto, o elemento fundamental desse contexto era a ausência dos setores populares da cena política. Em dez anos, o capitalismo no Brasil expandiu-se em ritmo acelerado e o fez cortando fundo o tecido social, de uma forma "selvagem". O caráter brutal das transformações vividas nesse período foi solidamente estabelecido através de uma boa quantidade de estudos e análises. No espaço dos últimos cinco anos 1969-1974 — conflitos localizados muito provavelmente multiplicaram-se no campo e na cidade, e apenas o rigor da censura à imprensa logrou impedir que eles se tornassem mais visíveis. Mas a eventual recorrência de tais lutas não era suficiente para alterar aquele quadro: indefesos diante da repressão policial e militar, impedidos de se expressar, os movimentos moleculares que se verificam então terminam encerrados em si mesmos e, bem ou malsucedidos, revelam-se incapazes de se difundir e, muito menos, de se articular.

Havia, certamente, como foco de tensão da Igreja, bem como outras instituições da chamada sociedade civil — a OAB, sobretudo — nos primeiros meses de 1974 esforços conseqüentes foram feitos a fim de neutralizá-las. Por outro lado, no plano econômico, as dificuldades esboçadas no ano anterior começavam a ganhar vulto, mas a sua natureza e o seu significado eram sistematicamente minimizados (somente no final de 1975 a gravidade da situação será reconhecida e se tentará adotar medidas mais conseqüentes para controlá-la).

Por que a decisão de liberalizar? Dados os termos do debate político nos anos Médici, dadas as condições que acabamos de apontar, caberia perguntar em troca: por que não liberalizar?

Atribui-se ao general Golbery do Couto e Silva a afirmativa de que a distensão teria vindo um pouco tarde, que o momento ideal para iniciá-la teria sido o dos anos de auge, no período Mediei. Dada a complexidade de sua trama, é sempre ingrato pensar em termos de se a história. Seja lá como for, nas condições prevalentes em meados da década passada, cedo a estratégia de distensão conduzida pelo governo Geisel começaria a esbarrar em obstáculos imprevistos e em resistências cruzadas que, no final, acabariam por redefinir a sua concepção, ampliando significativamente o escopo das alterações programadas.

Antes de mais nada, houve o impacto atordoante dos resultados eleitorais de novembro de 74. Conjugando uma repressão desenfreada e doses maciças de propaganda, o regime conseguira sufocar toda e qualquer manifestação de descontentamento e impor a imagem oficial de um Brasil harmônico, caminhando a largos passos na estrada da prosperidade. Ao fazê-lo, porém, ele foi vítima de seu sucesso. Não recebendo da sociedade respostas dissonantes que o obrigassem a corrigi-Ia, ele se deleitou com a versão mentirosa que transmitia e acabou por acreditar nela. "Ninguém, nem mesmo os emedebistas, precisa alimentar receios exagerados: a ARENA vencerá as eleições parlamentares de 15 de novembro por confortável 
margem de votos." ${ }^{19}$ Esta proposição enfática, que abre uma matéria sobre a campanha eleitoral publicada em periódico de ampla circulação, estabelece o postulado básico sobre o qual repousava o cálculo político do governo.

Certo da vitória, Geisel investiu pesadamente nessas eleições, que deveriam desempenhar um papel crucial na efetivação de seu projeto: confirmado nas urnas o apoio popular à "obra da Revolução", o ano seguinte seria dedicado à tarefa de institucionalização do regime, às esperadas reformas. Mas para que tal acontecesse, essas não poderiam ser eleições como as outras (as de 1970 e 1972), minadas em sua legitimidade pela onipresença da censura e pela violência das medidas de intimidação adotadas para assegurar de antemão os seus resultados. Era necessário que a oposição se envolvesse sem reticências no pleito e, dadas as garantias oferecidas, aceitasse de bom grado as evidências de sua futura derrota. "Dirigentes da ARENA se dispõem a procurar o comando do MDB para discutirem o andamento da campanha eleitoral - no seu entender será a campanha muito mais importante, para o processo de transformação do regime, do que os resultados eleitorais. O raciocínio é simples: a ARENA será, como nas eleições anteriores, o vencedor das eleições. Mesmo que perca 2 ou 3 cadeiras no Senado e outras 10 na Câmara dos Deputados (o que seria uma surpresa), isso não afetaria seu domínio formal e a impotência formal e real da

19 "Eleições: a Oposição na hora de falar", Revista Veja, 16.10.1974. oposição. Daí a tese de que a campanha valerá por si mesma, favorecendo o fortalecimento das condições para que se desenvolva o processo de reconciliação do regime com as normas democráticas." ${ }^{20}$

Entretanto, o esforço de persuasão não poderia se restringir aos círculos oposicionistas: o eleitor, que nas rodadas passadas se havia mantido distante das encenações cuidadosamente montadas e sancionado o seu protesto impotente ou o realismo de seu desinteresse com o voto nulo ou branco, esse eleitor igualmente deveria ser conquistado.

Por ambas as razões, os controles exercidos sobre as mídias são relaxados, a propaganda eleitoral no rádio e na IV ganha em conteúdo e vivacidade e ainda se vê reforçada pela publicidade oficial concitando permanentemente o povo â participação e ao voto. "Em filmes de propaganda intensamente divulgados pela IV, o governo reafirmou ao povo, nos últimos meses, que somos todos responsáveis pela solução dos problemas de educação, de saúde, de transporte, de trânsito, de abastecimento - de todos os problemas, enfim, que afetam o dia-a-dia da vida brasileira e o futuro do país. O objetivo dos anúncios - explícito na mensagem — era a valorização do voto, como instrumento de participação nas decisões que devem moldar nosso futuro... A mensagem é clara - clara e inequívoca - e não faz mais do que repetir e enfatizar a conclamação já tantas vezes lançada pelas principais autoridades nos últimos meses: conclamação

20 "Um acordo para o bem da nação", Revista Visão, 5.8.1974. 
â inteligência e à vontade de todos os homens socialmente válidos, para que se engajem na construção de um país mais forte, ...etc. etc" $"$.

Que todos votem, participem, tenham oportunidade de formar com independência sua opinião. Essa autoconfiança ilimitada é que faz das eleições de 74 um fenômeno único nesses 18 anos de autoritarismo. Em nenhum momento, antes ou depois, vai verificar-se algo análogo: em 65, as eleições são convocadas em meio a apreensões generalizadas e contra a opinião expressa dos setores militares mais radicais. Em 1970 e 1972 elas significavam muito pouco e foram conduzidas abertamente como uma farsa. Em 76, 78 e, agora, em 82, o elemento surpresa já foi banido, o regime perdeu suas ilusões e manobra muito perto da fraude para evitar embaraços maiores.

Munido de garantias mínimas, vendo abertos à sua mensagem os canais de comunicação com o eleitorado, o MDB faz um esforço de reciclagem e consegue estruturar uma campanha ágil e eficaz, pondo o acento nos temas econômicos e sociais, exaltados na consciência da população pelos números da crise econômica que se agravava. No lapso de alguns meses, acende-se na opinião oposicionista um debate; votar no MDB, ou expressar o repúdio â ditadura anulando o voto. A questão era velha de oito anos, pelo

21 "Campanha política: o melhor resultado de 1974", Revista Vilão, 18.11.1974. menos. Mas agora, as vozes que sustentavam a segunda daquelas alternativas começavam a ficar isoladas.

Setembro... outubro... indicações de que a campanha do MDB crescia passavam a se acumular. "Na última semana — noticiava a revista Veja — o senador Petrônio Portella foi ao Palácio do Planalto anunciar ao presidente que a ARENA não teme nenhuma derrota comprometedora nas eleições de 15 de novembro. Em muitos estados, admite-se que a oposição terá mais votos que nos pleitos anteriores." E agregava o comentário: "É possível acreditar que, além de uma revigorada confiança em sua vitória, os dirigentes arenistas levaram de Brastlia a certeza de que a campanha eleitoral não chega a ser uma ameaça à normalidade política". ${ }^{22}$

No início de novembro a inquietação nos círculos oficiais contrasta com o otimismo crescente dos quadros da oposição. Uns e outros, porém, são tomados de surpresa quando os jornais passam a gritar nas primeiras páginas, com manchetes em letras garrafais e textos em negrito, os resultados preliminares do pleito. Confirmados $\operatorname{logo}$ a seguir, eles davam ao MDB a vitória, nas eleições majoritárias, em 16 estados. No cômputo geral, a oposição elegia 16 dos 22 senadores e 160 dos 364 deputados, o que representava um aumento expressivo em sua representação no Congresso Nacional até então, ela contava apenas com 7 dos 66 senadores e com 87 dos 310 deputados.

22 "Eleições - uma ciranda da boa vontade", Revista Veja, 30.10.1974 . 
Vencido o clima de perplexidade gerado por esses resultados, a preocupação toma o seu lugar. E agora, o que acontece? Assimilaria o regime uma tão contundente derrota? No início de dezembro, a se fiar na versão das "fontes bem informadas", a resposta era positiva: para os "dirigentes mais responsáveis da ARENA, assim como para o governo, a clara vitória do MDB reflete "uma manifestação popular dos anseios nacionais, que favorece a colaboração não só para evitar que se superponha à crise econômico-financeira a crise política, mas para que ambas as crises se resolvam pacificamente". ${ }^{23}$ Coincidentemente, esse mesmo era o significado atribuído ao pleito pela cúpula moderada do MDB; “A oposição repele o negativismo e proclama-se confiante e com disposição construtiva. Assim afirma seu líder no Senado, Amaral Peixoto. É sensível o desejo de entendimento. A perplexidade cede lugar à confiança, sobretudo pela constatação de que a vitória do MDB ocorreu em acentuada convergência com o governo". ${ }^{24}$ No final do ano, todos pareciam dispostos a encaminhar-se para uma saída onde prevaleceriam o compromisso e a colaboração.Dois meses depois, no início de fevereiro, já é outra a atmosfera.Abalada pela divulgação em grande estilo dos informes oficiais sobre o desbaratamento de uma ampla rede do Partido Comunista Brasileiro e da existência de elementos comprovando o compromisso de muitos dos candidatos recém-eleitos

23"O Brasil depois das eleições", Revista Vilão, 2.12.1974.

24 Idem. do MDB com essa organização, a oposição parlamentar vive momentos de aguda tensão, acossada pelos rumores de iminentes cassações. Por algumas semanas a ansiedade persiste. Ela se reduz, à medida que sinais tranqüilizadores passam a ser emitidos do governo. Em março, Geisel põe um ponto final nos temores restantes brindando o MDB pela excelência de seu desempenho eleitoral, ao pronunciar na reabertura dos trabalhos do Congresso aquele que foi, provavelmente, o mais liberal de seus discursos como presidente.

No entanto, os problemas continuavam pendentes. A Constituição em vigor previa a realização de eleições diretas para governadores em 1978; tendo em vista a vitória certa da oposição nos principais estados, como seriam elas realizadas? E a continuidade do projeto de distensão? . Com mais de $1 / 3$ na Câmara, o MDB detinha poder de veto na votação de matérias constitucionais; estaria o governo disposto a abrir mão de seu papel de "árbitro exclusivo da oportunidade de cada avanço na evolução do regime" (palavras de Geisel) e negociar o conteúdo e o ritmo do processo, quando essa oposição, forte na arena parlamentar, tinha bases tão frágeis nas relações de poder predominantes no conjunto da sociedade?

O segundo impacto sofrido pelo governo Geisel no encaminhamento de seu projeto político foi ocasionado pela re-ação articulada da extrema direita militar. Um dos aspectos centrais da estratégia da distensão, apontado insistentemente na época pelos analistas políticos de plantão, era o reforço da autoridade central da Presidência da República e o consequiente enquadramento dos 
organismos de repressão política que no período anterior haviam conquistado um grau de autonomia incompatível com os propósitos anunciados de normalização institucional. Já nos últimos meses de Médici, quando a intenção de levar a cabo mudanças nesse sentido se toma patente, esses organismos se mobilizam na defesa, de suas prerrogativas e imprimem uma alteração significativa no estilo de suas práticas. Datam dessa época — final de 1973 — os desaparecimentos, as sessões de interrogatórios em aparelhos privados, enfim, toda uma série de ações paralelas que se subtraíam aos registros e à memória da burocracia policial militar. Iniciadas em fins de 73, essas ações se intensificam ao longo de 1974 e serão contidas apenas no final do ano seguinte. Por intermédio delas, foram dizimadas dezenas de militantes e quadros dirigentes da oposição clandestina, que passaram a sumir, como que de repente, sem deixar traços. $^{25}$

Desde os primeiros momentos, portanto, a extrema-direita militar confronta o governo Geisel, presenteando-o com a "crise dos desaparecidos" e o desgasta severamente em vista da incapacidade deste de solucioná-la. Por todo o ano de 1974, compromissos de esclarecer casos de desaparecimento são assumidos e nenhum deles será levado até o fim.

Com a vitória do MDB nas eleições de 15 de novembro, as

25 Sobre essa nova "metodologia" e os resultados através dela alcançados, ver Bernardo Kucinski, Abertura, a história de uma crise, São Paulo, Editora Brasil Debates Ltda., 1982, pp. 42 e segs. tensões provocadas pela "linha dura" adquirem maior intensidade. Agora, não se trata apenas da ação repressiva autonomizada. O tom dos pronunciamentos, das ordens de serviço, dos comunicados se toma mais agressivo e mal se disfarçam as ameaças. Com o respaldo de comandos — sobretudo, em São Paulo, área do II Exército - a repressão, ora voltada contra o PCB, segue em sua mórbida batida, desconhecendo limites ou normas. As prisões se sucedem. Nas listas de desaparecidos, novos nomes se agregam.

No dia 25 de outubro de 1975 morre em virtude das torturas sofridas no DOI-CODI, em São Paulo, o jornalista Vladimir Herzog. Essa morte comoveu a opinião pública de uma forma particular por várias razões - não vitimava um militante clandestino, mas um cidadão de vida comum, profissional de prestígio que havia atendido voluntariamente a convocatória do organismo policial; ocorrera na prisão, sob a guarda da autoridade co-autora, responsável por sua segurança física; a versão de suicídio apresentada pelo DOI-CODI era de toda evidência falsa — por essas e outras razões ela dramatizava ao extremo o clima de arbítrio reinante e a insegurança a que todos se sujeitavam. Uma semana depois, com a participação do cardeal de São Paulo, D. Paulo Evaristo Arns, realiza-se um culto ecumênico em memória de Herzog. Pela primeira vez em muitos anos assistia-se no Brasil uma manifestação pública com esse caráter.

Em 16 de janeiro de 1976, outro preso morre sob torturas no mesmo local. Era o operário metalúrgico Manoel Fiel Filho. Novamente o suicídio é alegado como causa. Desta feita, porém, as 
conseqüências serão outras: em ação rápida, Geisel demite o comandante do II Exército, substituindo-o por um oficial de sua inteira confiança. Por algum tempo o foco principal de contestação no Exército estará desarticulado.

A terceira fonte de pressão exercida sobre o governo Geisel em seus primeiros anos foi constituída pela campanha da antiestatização. Deslanchada pelo discurso de Eugênio Gudin ao receber o título de Homem de Visão -1974, ela se mantém, por dois anos seguidos, impulsionada pelos maiores jornais e pelas revistas de negócios mais importantes do país, mobilizando lideranças e entidades empresariais, que tomam públicos os seus temores quanto ao avanço desregrado da intervenção estatal na economia e fazem propostas no sentido de refreá-la. Alguém se referiu a essa campanha como a "rebelião empresarial". Ela sacudiu o poder em suas bases sociais mais sólidas. Não vamos procurar acompanhá-la em seu desenvolvimento, nem aventar hipóteses com a pretensão de explicá-la. Para os objetivos desse artigo, basta dizer que, embora localizada, embora dirigida contra certas dimensões da intervenção estatal, não obstante fosse quase sempre muda em relação à natureza autoritária do regime, a oposição empresarial que se manifestava através da aludida campanha debilitava o poder por uma razão básica: porque a mera manifestação pública de um dissenso que não podia ser pura e simplesmente reprimido - nem sequer ignorado — se chocava com — e neste sentido contestava - a reivindicação do Estado autoritário de ser ele o promotor de um interesse nacional substantivo, cujo segredo a ninguém mais seria dado decifrar.

Estuário das três linhas de tensão apontadas, 1977 é o anochave no processo de transformação do regime. Iniciado com enormes expectativas sobre as reformas políticas que deveriam preceder e pavimentar o caminho às eleições diretas para os governos dos estados, a se realizarem em novembro do ano seguinte, todo o mês de janeiro é dominado pelo noticiário e pelas especulações em tomo da missão Portella — presidente do Senado — encarregado de semear junto às lideranças oposicionistas o compromisso sobre determinados pontos tidos pelo governo como inegociáveis. A conjuntura sofre uma inflexão brusca no começo do mês seguinte, quando, repercutindo declarações do ministro da Indústria e do Comércio, Severo Gomes, vários empresários de destaque se manifestam através da imprensa reclamando a volta ao Estado de Direito e defendendo o retomo dos militares â caserna. A partir desse episódio, que culminou com a demissão do ministro, inúmeros sinais são emitidos, dando a entender que a intenção de buscar uma saída negociada para o impasse político, se um dia existira, havia sido abandonada. No dia 3 de fevereiro, o governo cassa o mandato do vereador gaúcho Glênio Perez; menos de duas semanas depois, no dia 15, outra cassação, sendo atingido o vereador, também gaúcho, Marcos Klassman. No dia seguinte, o comandante do $11^{\circ}$ Batalhão de Infantaria, sediado em Campinas, proíbe a realização de debate com quatro bispos progressitas naquela cidade. No dia 18 , o presidente da ARENA, Francelino Pereira, divulga nota oficial do partido sobre a 
cassação de Klassman, acusando os políticos do MDB de "agentes do comunismo". 22 de fevereiro: "Na ARENA já não se acredita que as reformas políticas serão democratizantes. Para o governo nada tem para ser mudado. A reforma seria simples acomodação, destinada a manter o quadro vigente". ${ }^{26} 4$ de março: "Em raros momentos, no período pós-revolucionário, houve tanta confusão e desinformação. Faltam indicações sobre tudo, a não ser a de que o governo imporá eleições indiretas para governadores para o próximo ano".$^{27}$

Menos de um mês após, o acerto dessa afirmação seria confirmado. Tomando como pretexto a negativa do MDB em aprovar sem emendas um projeto de reforma do Judiciário, matéria que requeria maioria qualificada de $2 / 3$, no dia 1 de abril Geisel decreta o recesso temporário do Congresso e, depois de reunir-se com seus assessores mais próximos nos dias subseqüentes, edita no dia 14 um conjunto de disposições modificando o regime político vigente em várias de suas esferas Composto de 14 emendas a artigos da Constituição de 1969, e três artigos novos, além de seis decretos-leis, o "pacote de abril" — como se tomou conhecido esse novo ficasse contemplava as seguintes medidas principais: eleições indiretas para escolha de governadores, com ampliação do colégio eleitoral; eleição de $1 / 3$ do Senado por via indireta e instituição de sublegendas, em

26 "Arenistas já temem reforma casuística", O Estado de S. Paulo, 22.2.1977.

27 "Políticos nada sabem, desorientação é total", O Estado de S. Paulo, 4.3.1977. número de três, na eleição direta dos restantes; extensão às eleições estaduais e federais da legislação restringindo a propaganda eleitoral no rádio e na TV; alteração no quorum para a votação de emendas constitucionais pelo Congresso, de 2/3 dos membros para maioria simples; alteração do colégio eleitoral que elege o presidente da República; ampliação de cinco para seis anos do mandato presidencial.

A intensidade da reação provocada por mais esse ato de força, que por sua brutalidade rivalizava com as medidas mais duras até então impostas pelo regime e que se chocava tão frontalmente com os proclamados intuitos de distensão e de normalização institucional, a intensidade da reação, dizíamos, toma todos de surpresa. No dia 14 de abril é divulgado o pacote. Cinco dias depois, o Conselho Federal da OAB aprovava por unanimidade nota de repúdio ao que classificou de crescente desfiguramento do Estado de Direito e reclamava o fim do AI-5 acompanhado de ampla reforma constitucional a ser feita por uma assembléia constituinte eleita especialmente para esse fim. Entrementes, estudantes do mais tradicional centro de ensino jurídico do país - a Faculdade de Direito do largo de São Francisco, em São Paulo, saíam à rua solenemente vestidos de beca e faziam o enterro simbólico da Constituição, garantidos, política e fisicamente, por professor catedrático, igualmente ultrajado em sua consciência jurídica pela prepotência do regime. No início do mês seguinte, o movimento estudantil - que desde 1975 vinha se reorganizando num trabalho 
paulatino desenvolvido no interior das escolas ganha as manchetes dos principais jornais do país, ao sair em passeata de protesto contra a repressão policial em São Paulo e ao realizar uma grande concentração de massa, no Rio de Janeiro, com o mesmo propósito, a despeito do pesado aparato mobilizado para obstá-lo.

Era o despertar da "sociedade civil": como se dizia na época registrado em detalhes por alguns dos principais órgãos da grande imprensa - que o aplaudiam e encorajavam em suas páginas editoriais. Assim: Junho - estudantes da Universidade de Brasília entram em greve contra punição aplicada a colegas; em Belo Horizonte é dissolvido o III Encontro Nacional de Estudantes visando à reconstituição da UNE - contam-se às centenas as prisões; presidente do Movimento Feminino pela Anistia rompe cerco da guarda de segurança do Congresso e entrega relatório de familiares de presos, desaparecidos e exilados a Rosalyn Carter, ora em visita ao país; MDB lança tese da Constituinte em simpósio reunido em Porto Alegre; comunidade acadêmica reage à tentativa do governo de impedir a realização da $29^{\circ}$ Reunião da Sociedade Brasileira para o Progresso da Ciência, negando-lhe os fundos necessários. Julho reunida na PUC/SP, SBPC vota moção pela anistia ampla e irrestrita na sessão final de seu conclave; encontro dos presidentes das seccionais da OAB, em São Paulo, abre debate e demanda a plenitude do habeas corpus; publicando na íntegra cartas de mães, imprensa abre amplo espaço às denúncias de torturas feitas por membros de organização de esquerda presos no Rio e em São
Paulo; "O Governo isola-se da opinião nacional" — proclama o editorial do "Estado" . ${ }^{28}$ Agosto — comemoração do sesquicentenário dos cursos jurídicos no Brasil: leitura da Carta aos Brasileiros, encerramento com passeata de 7000 pessoas, seguidas de perto pela polícia; "Estamos caminhando rapidamente para o aprimoramento democrático. Até o final deste governo deverá ter terminado o regime de exceção" 29 - agora são os empresários que começam a se expressar publicamente nos termos da linguagem política liberal. Em setembro e outubro o movimento sindical, que vinha se rearticulando lentamente nos anos anteriores e já esboçava o perfil de uma nova identidade, intervém em conjunto pela primeira vez desde 1964 na cena política, conduzindo a campanha pela "reposição salarial". Com esta, projeta-se nacionalmente o nome de Luiz Inácio da Silva, o Lula, presidente do Sindicato dos Metalúrgicos de São Bernardo do Campo, principal promotor da iniciativa.

No espaço de poucos meses a conjuntura política sofrera uma guinada. No ano anterior o governo havia cassado o mandato de inúmeros parlamentares (Marcelo Gato, Nelson Fabiano, Nadyr Rosseti, Amaury Muller e Lyzâneas Maciel), editado a lei Falcão que praticamente eliminava dos meios de comunicação de massa a propaganda eleitoral e disputado com relativo grau de sucesso eleições para prefeituras e câmaras municipais. No final de 76 ainda

28 O Estadode S.Paulo, 6.7.1977.

29 Palavras de Ayrton Girão, Presidente da ABRASCA - Associação Brasileira das Sociedades de Capital Aberto, Gazeta Mercantil, 22.8.1977. 
repercutiam na memória as duras palavras de Geisel, que em discurso pronunciado em agosto de 1975 repudiara os "liberais ingênuos, ou mal intencionados", supostamente preocupados com os rumos da distensão, quando a distensão verdadeiramente necessária o governo a vinha fazendo ao efetivar medidas de alcance social. No final desse ano a situação parecia estar sob estrito controle e deter o governo o monopólio da iniciativa política. Seis ou sete meses depois, em julho/agosto, este parecia estar mergulhado em profundo isolamento, suas interdições, até então sempre validadas, iam sendo derrogadas na prática e contra ele parecia erguer-se um amplo espectro de forças, que cobria da esquerda à centro-direito, dos peões do $\mathrm{ABC}$ à grande burguesia paulista, tendo como denominador comum a aspiração pelo Estado de Direito e a defesa das "liberdades democráticas".

Tal imagem, entretanto, é resultado de um exame incompleto e superficial. Não apreenderíamos corretamente essa conjuntura, nem poderíamos compreender os seus desdobramentos se não integrássemos na análise um dado crucial: a questão sucessória e a crise por ela desencadeada.

Terreno batido, os termos em que se colocava o problema sucessório não eram novos. De um lado estavam Geisel e o círculo de seus assessores mais íntimos — o "grupo palaciano"; de outro, o ministro da Guerra, Sílvio Frota, candidato nato à Presidência como expressão mais insigne do aparelho militar. Buscando preservar o controle do processo, Geisel desenvolve uma política de duas caras: oficialmente, joga para o futuro a discussão do problema, condenando como prematura e inaceitável qualquer manifestação sobre candidatos. Ao mesmo tempo, faz vista grossa ã operação de marketing desenvolvida pelos palacianos, que lançam publicamente o nome do general João Batista Figueiredo, chefe do todo-poderoso SNI, vestindo-o desde o início com roupagem liberal. Para embaralhar mais as coisas, aparece a candidatura civil do ex-ministro das Relações Exteriores e líder do movimento de 64, Magalhães Pinto. Vendo o terreno fugir aos seus pés, instigado pelas manobras dos adversários, Frota passa a se movimentar mais ostensivamente como candidato, intensificando contatos e articulando um estrepitoso bloco de apoio parlamentar.

Em agosto de 77, do ponto de vista do grupo Geisel, o quadro apresentava-se esquematicamente desta forma: de um lado, largas parcelas da opinião pública o hostilizavam, levantando a bandeira da volta ao Estado de Direito e à convivência democrática. Tratava-se aí de uma convergência momentânea de forças heterogêneas; nela o papel hegemônico era exercido pela oposição grã-burguesa liberal, cujos arroubos libertários ainda não haviam passado pela prova dos nove do enfrentamento das lutas sociais. De outro, a direita militar buscava a ofensiva com a candidatura Frota, produzindo um discurso virulentamente anticomunista, dirigido quase que exclusivamente ao "público interno".

Nesse contexto, Geisel retoma a iniciativa e num suceder de lances rápidos consegue redefinir a seu favor o quadro.Primeiro, numa operação iniciada em agosto, ele vai invadir o campo da 
oposição reativando a "missão Portella" — que agora passará por cima do MDB e ouvirá diretamente os "setores representativos da sociedade" Guristas, clérigos, empresários, sindicalistas etc.) — e anunciando para o ano seguinte a extinção do AI-5, além do advento das propaladas reformas. Depois, em outubro, num golpe preventivo que envolveu elevada dose de malícia e cuidadoso preparo, ele demite o ministro da Guerra e, ao mesmo tempo, anula o dispositivo da extrema-direita militar, cooptando para o seu lugar o general Belfort Bethlen, um dos esteios da linha dura no Exército. No final de 1977, com a frente militar desimpedida e com o candidato oficial sendo apresentado como o futuro presidente da abertura, Geisel estava forte o bastante para arrostar as chuvas e os ventos que ainda iriam açoitá-lo antes do término de seu mandato.

A sorte está lançada. Nesse momento, a "abertura" tal como será praticada nos primeiros anos do governo Figueiredo, em suas linhas gerais, já estava decidida.

1978 foi um ano de intensa atividade oposicionista. logo de saída, houve a dissidência do general Hugo Abreu, o inconformismo de setores da oficialidade média do Exército, a Frente Nacional de Redemocratização e a candidatura alternativa do general Euler Bentes Monteiro, rompendo por alguns momentos a imagem de coesão e unidade que a hierarquia das Forças Armadas tanto se empenhava em preservar. Em maio, era a classe operária que imprimia a sua marca no rumo dos acontecimentos com a greve do $\mathrm{ABC}$, que logo iria proliferar, desdobrando-se num movimento impetuoso que se estendeu a um sem-número de categorias e que somente dois anos mais tarde seria domado. Finalmente esse figurante incômodo, não convidado, entrava em cena e ocupava o seu lugar. "Braços cruzados, máquinas paradas" — com a greve do ABC e o movimento que ela precipita, abre-se um espaço enorme no campo das práticas e no imaginário político. Súbito, o possível dilatase, o novo começa a brotar. Como que de repente, a política salarial e a Lei de Greve - colunas mestras da ordem social imposta a partir de 1964 - caíam por terra e o próprio governo parecia inclinado a assinar o seu obituário. "EMPRESÁRIOS DEVEM SE PREPARAR - uma nova realidade pode levar o fim da tutela do Governo nas relações com os empregados. Busca-se nova política salarial que inclua as negociações diretas." ${ }^{30}$ Nova realidade - quase simultaneamente a tentativa de dar a ela a expressão política adequada: poucos meses depois nascia a ideia de um Partido dos Trabalhadores.

1978 foi, ademais, o ano da luta pela anistia, da constituição no discurso público da figura do "preso político" (em contraposição à do "terrorista", "preso de direito comum", fórmulas estigmatizantes que o poder insistia em afirmar); da ampla difusão de informações sobre o mundo do exílio, os seus grandes e pequenos dramas, suas angústias e esperanças; do lento retomo dos cassados, banidos e

30 Recado transmitido pelos ministros da Fazenda e do Planejamento a 22 dos mais representativos empresários paulistas, durante encontro de sete horas realizado em Brasília, Diário Comércio e Indústria, 28/30.10.1978. 
exilados, os quais, embora ausentes, voltavam a habitar as páginas do noticiário político. Foi igualmente um tempo de introspecção, de longas e cansativas discussões sobre propostas partidárias diversas.

Mas 78 não foi propriamente um ano oposicionista. Ao lado desse impulso que partia de baixo e de fora, conjugado a ele, houve a missão Portella e, sobretudo, a marcha triunfal da candidatura Figueiredo. Vale chamar a atenção: antes mesmo de vir à luz, a "abertura" começou a produzir efeitos e a render dividendos políticos consideráveis. E em nome da abertura que a quase totalidade da grande imprensa vai aderir ao candidato oficial, denunciando como aventura golpista a hipótese de resistência militar. E a promessa da abertura que aplaina o caminho para o realismo dos segmentos ditos liberais do empresariado que, fugindo a qualquer contato com Euler, vão a Figueiredo na qualidade de futuro presidente, expondo os seus pontos de vista, formulando suas demandas e propostas. Na verdade, o ensaio de abertura feito em 78 vai induzir à diluição da frente que chegou a se esboçar no ano anterior. Tomados de surpresa pelo movimento social emergente, receosos de um aprofundamento das dissensões nas Forças Armadas, trêmulos ante a ideia de que o processo de mudança pudesse fugir ao controle e conduzir à "desordem", ao "imponderável", os setores liberais que haviam fustigado o governo pouco tempo antes aplaudem o projeto de abertura, nele enxergando a saída possível e desejável para o impasse político em que se debatia o país.

Nesse contexto, não é de surpreender tenham sido aprovadas sem grande estardalhaço as reformas propostas por Geisel. Divulgado a 19 de junho - poucos dias depois de ter sido suspensa a censura prévia que ainda pesava sobre os semanários Movimento e O São Paulo, além do diário Tribuna da Imprensa - o anteprojeto das reformas suprimia os instrumentos mais nitidamente discricionários da legislação vigente, sem alterar, no entanto, a face autoritária do regime. Com efeito, embora determinasse o fim das cassações através do AI-5; o fim das suspensões de direitos políticos com base no AI-5; o fim do direito do presidente de fechar o Congresso; o fim de outros poderes arbitrários — o de remover juízes e aposentar compulsoriamente funcionários públicos, por exemplo -; o fim das penas de morte, banimento e prisão perpétua;o restabelecimento do habeas corpus para crimes políticos, ele preservava a Lei de Segurança Nacional — que em outubro seria alterada, sendo ampliada a sua abrangência e tomada menos custosa, politicamente, a sua aplicação; mantinha as dezenas de Atos Institucionais e Complementares, que perderiam apenas os dispositivos que "contrariem a Constituição"; não revogava o pacote de abril, nem a Lei Falcão, e ainda criava uma figura nova: o "Estado de Emergência".

Esse instrumento, que dispensa a aprovação pelo Congresso, faculta ao presidente: suspender todas as garantias individuais; suspender todas as liberdades públicas; intervir em sindicatos; suspender imunidades parlamentares; atribuir às Forças Armadas todos os poderes de polícia e entregar ao julgamento de tribunais 
militares todos os que forem presos durante a sua vigência.

Em março de 1974, Geisel proclamava a sua aspiração de ver os instrumentos excepcionais superados "pela imaginação política criadora, capaz de instituir, quando for oportuno, salvaguardas eficazes dentro do contexto constitucional". No final de 78, o momento chegara e o "Estado de Emergência", junto com a Lei de Segurança Nacional reformada, ali estavam para mostrar que a cri atividade política não havia faltado.

As reformas políticas serão votadas em novembro, poucos dias antes das eleições parlamentares. Em março do ano seguinte, ao transmitir o governo ao general Figueiredo, Geisel podia olhar para trás com a consciência de ter percorrido um longo trajeto. Muito chão teria ainda de ser batido, mas esta já é outra história.

\section{O eleitorado, os partidos e o regime autoritário brasileiro}

Fábio Wanderley Reis

\section{I}

A possibilidade de compreender e avaliar a história recente dos partidos políticos no Brasil supõe, naturalmente, a possibilidade de diagnosticar com correção certos aspectos mais fundamentais do processo político vivido pelo país. Contrariamente aos modismos correntes em determinados quadrantes das ciências sociais contemporâneas, receosos de "evolucionismos" ou interpretações "lineares", sou da opinião de que se impõe, na busca de diagnósticos como esse, enfrentar o desafio de se elaborar uma teoria adequada da mudança política na época moderna, para que se possa, assim, capturar a lógica em jogo em qualquer processo particular.

Seria obviamente impróprio pretender discutir aqui os muitos problemas envolvidos na formulação de tal teoria, especialmente as dificuldades de ordem epistemológica que surgem na articulação entre a dimensão histórica dos fenômenos sociais e os desígnios "estruturais" e formalizastes contidos em qualquer esforço teórico dificuldades estas que se colocam de forma particularmente clara quando se trata de uma teoria da mudança. ${ }^{1}$ Creio ser indispensável,

1 Ver, a respeito, Fábio W. Reis, "Mudança, Racionalidade e Política", em Bolivar Lamounier (org.), A Ciência Política nos Anos 80, Brasília, Editora 
porém, tratar de explicitar o que entendo corresponder à natureza do atual regime autoritário brasileiro, e me parece útil, com esse propósito, apresentar sucintamente as grandes linhas de uma reflexão teórica que procurei desenvolver em trabalhos anteriores com respeito ao tema geral da mudança política a partir da crítica à literatura recente sobre "desenvolvimento político".2

A discussão teórica aí empreendida, partindo da análise abstrata dos dilemas envolvidos na ação coletiva e em qualquer forma de organização política, baseia-se nas relações entre "sistemas de interesses" e "sistemas de solidariedade" — tal como estabelecidas por Alessandro Pizzorno em artigo de alguns anos atrás ${ }^{3}$ — para chegar à noção de "mercado político" como aquela que permite sintetizar tais relações. Propõem-se, ao cabo, três fases ou estádios analiticamente distinguíveis no processo de desenvolvimento político, denominadas "política pré-ideológica", "política ideológica" e "política pós-ideológica". O critério para a distinção entre tais estádios é o grau de expansão do "mercado político", o qual está condicionado pelo caráter mais ou menos envolvente ou restritivo das formas de solidariedade prevalecentes, que por sua vez condicionam

da Universidade de Brasília, no prelo.

2 Ver especialmente Fábio W. Reis, "Solidariedade, Interesses e Desenvolvimento Político", em Jorge Balán (org.), Centro e Periferia no Desenvolvimento Brasileiro, São Paulo, DIFEL, 1974; e "Brasil: 'Estado e Sociedade em Perspectiva", Cadernos DCP, n 2, dez. 1974. Os parágrafos que se seguem de imediato são tomados diretamente deste último texto.

3 Alessandro Pizzorno, "Introduzione allo Studio della Partecipazione Política", Quaderni di Sociologia, 15, 3-4,jul-dez., 1966. as feições assumidas pela confrontação de interesses no processo político. A análise dos obstáculos à expansão concomitante da solidariedade territorial e do "mercado político" permite incorporar coerentemente os fatores de ordem estrutural, institucional e sócio psicológica geralmente considerados de maneira fragmentária na literatura dedicada ao tema do desenvolvimento político.

Assim, a expansão da solidariedade territorial e ao mercado político em uma coletividade - expansão cujo grau máximo corresponderia à condição hipotética descrita como política pósideológica, caracterizada pelo livre jogo de interesses individuais é vista como embaraçada sucessivamente, nas duas outras fases, por obstáculos de natureza estrutural e sócio-psicológica típicos de cada fase. A política pré-ideológica ou tradicional se distingue pela proeminência assumida por problemas relativos à emergência e consolidação da aparelhagem estatal enquanto núcleo de poder efetivo e coextensivo, no que se refere à capacidade de fazer valer as decisões que dele emanem, à coletividade como um todo, em suas dimensões social e territorial. Os obstáculos que se opõem ao processo correspondente, o qual chamo "institucionalização do poder", referem-se ao substrato material (condicionado por problemas de ordem ecológica e por fatores como a estrutura de comunicações e a intensidade e o caráter das transações econômicas) necessário ao desenvolvimento e à penetração dos instrumentos organizacionais e dos símbolos de toda ordem nos quais se funda a pretensão de determinada aparelhagem governamental de vir a 
constituir-se em centro de decisões efetivas em todo o âmbito de determinado território.

Um segundo tipo de obstáculos à plena vigência do mercado político refere-se à existência de focos particulares de solidariedade capazes de competir, por sua natureza, com a própria coletividade pela lealdade de seus membros. No contexto representado pela passagem da política tradicional à ideológica, este tipo de obstáculos assume especial relevância, situando o problema da "institucionalização da autoridade" em conexão com a irrupção de demandas de igualdade e com o questionamento concomitante da ordem política erigida no estádio anterior. O substrato para a emergência de tais problemas está dado pelo processo de mobilização social e pelo aparecimento de grupos tais como as classes sociais, enquanto focos de solidariedade universalística, em substituição aos vínculos de natureza pessoal e clientelística típicos da política préideológica. Tais grupos se caracterizam por serem grupos "multifuncionais" de objetivos difusos, que correspondem a subculturas envolventes, distinguindo-se, ademais, pela natureza não voluntária (ou "adscritiva", para recorrer à expressão com frequiência utilizada, em acepção pouco vernácula, na tradução do termo inglês ascriptive) da participação de seus membros. Um aspecto crucial da dinâmica da expansão do mercado político situado pela emergência do problema da igualdade concomitantemente com a relevância assumida por tais grupos tem a ver precisamente com as pressões 110 sentido de levar às últimas conseqüências o processo deflagrado pela mobilização social, em que as relações reguladas por princípios "adscritivas" são parcialmente substituídas por outras reguladas pelos princípios potencialmente igualitários do mercado.

$\mathrm{Na}$ perspectiva propiciada por esse esquema, o ponto de partida para à discussão dos regimes autoritários em geral consiste em concebê-los como vicissitudes da política ideológica. As condições mais favoráveis à ocorrência de regimes autoritários do tipo que tem caracterizado, em tempos recentes, alguns países da América Latina e da Europa meridional encontram-se nas fases intermediárias da política ideológica - mais precisamente, nas circunstâncias que se ajustam à noção de "pretorianisma de massas", de Samuel Huntington ${ }^{4}$. Aí, a emergência dos interesses e dos focos de solidariedade correspondentes à classe trabalhadora e aos "setores populares" em geral vem pôr em xeque os arranjos institucionais antes precários que resultam da incorporação prévia das classes médias ao processo político. A marca decisiva da política ideológica como tal sendo o surgimento das classes sociais (e de outros grupos multifuncionais, tais como os grupos ou identidades étnicas) como o foco principal do processo político, o pretorianismo de massas - e o autoritarismo do tipo em questão como resposta a ele - corresponde a um momento ou configuração de traços particular, que diz respeito à mobilização das classes populares. Diversos fatores, entre os quais

4 Samuel P. Huntington, Political Order in Changing Society, New Haven, Yale University Press, 1968, esp. cap.4. 
avulta em importância o grau em que a assimilação prévia das classes médias se tenha consolidado sob a forma de um controle efetivo do processo político por parte delas ou resultado, ao invés disso, em sua inserção insegura numa estrutura sócio-política em que se preserve o caráter basicamente tradicional e oligárquico, respondem pelas chances de que o processo geral se encaminhe seja no rumo do "tipo ideal" de política ideológica (sob a forma, por exemplo, da política de partidos ideológicos, tal como se encontra na França ou na Itália contemporâneas), seja no do padrão de regimes bonapartistas ou de outros regimes "fortes" controlados pelos militares. Ademais, a alternativa assim expressa pode não ser uma verdadeira alternativa, correspondendo antes a duas etapas distintas, nas quais a política de partidos ideológicos culminaria desenvolvimentos que passariam, através do bonapartismo ou do autoritarismo, entre outros "arranjos" possíveis.

Como quer que seja, distintas formas ou variações do próprio autoritarismo irão depender da medida em que o processo de mobilização e ativação política das classes populares tenha podido desdobrar-se anteriormente aos eventos que levem ao efetivo estabelecimento do regime autoritário - e da medida em que, como consequiência, aquelas classes revelem um grau de "maturidade" que permita falar de uma entidade coletiva que compartilhe efetivamente (vale dizer, subjetivamente) uma identidade comum e propósitos comuns razoavelmente claros, e seja assim capaz de agir coletivamente. Traços de um regime autoritário tais como o fato de depender amplamente da coerção direta ou de poder contar, ao contrário, com a manipulação ideológica e simbólica, bem como muito do que tem a ver com os prospectos de estabilidade e permanência do regime, podem ser referidos a essa maturidade dos setores populares como classe - como classe trabalhadora, talvez. Isso pode ser visto como forma diferente de dizer que muito dos prospectos de institucionalização que eventualmente se abrem para os regimes autoritários - ou seja, de que estes venham a mostrar-se capazes de se organizarem de maneira a assegurar estabilidade sóciopolítica sobre a base de uma "fórmula política" que permaneça autoritária e restritiva no que diz respeito à participação dos setores populares - depende da realização mais ou menos cabal do processo de formação de classe relativamente à classe trabalhadora e, portanto, do conjunto de traços ideológicos, intelectuais e sócio-psicológicos (envolvimento e consciência política, informação sobre assuntos de interesse político, capacidade de vincular e estruturar informação sobre questões de natureza heterogênea e de perceber ou estabelecer sua relevância política) que tendem a associar-se com o cumprimento daquele processo.

\section{II}

O quadro composto pelas principais proposições envolvidas nessa concepção das relações entre mobilização e formação de classe, de um lado, e a viabilidade, chances de estabilização e outras características dos regimes autoritários, de outro, tem, como parece 
claro, uma feição geral bastante ortodoxa e mesmo clássica. Apesar de numerosas polêmicas mais ou menos carregadas de equívocos que se podem encontrar nesse terreno ${ }^{5}$ - como, de resto, em tudo o mais nas ciências sociais -, tais proposições se acham pelo menos implícitas, por exemplo, na famosa passagem de Marx sobre os camponeses franceses encontrada em O Dezoito Brumário de Luís Bonaparte, a qual pode ser lida como um enunciado da relação entre a mobilização social e a formação de classes sociais efetivas, além de inscrever-se num contexto em que se trata precisamente de explorar a relação entre tais processos e a ocorrência de experimentos autoritários de certo tipo. ${ }^{6}$ Parece possível, contudo, avançar além desse ponto se se traduzem aquelas proposições nos termos de alguns instrumentos conceituais contemporâneos e se examina, a partir daí, sua articulação em forma analiticamente mais precisa.

Um modelo conceitual que parece claramente relevante é o modelo da "centralidade" desenvolvido por cientistas políticos americanos para dar conta dos dados sobre a participação política nos Estados Unidos. Tal como empregada nos estudos americanos, a noção de centralidade da posição social global de um indivíduo é

5 Tenho em mente especialmente certo tipo de crítica dirigido por autores marxistas, particularmente latino-americanos, à chamada teoria da modernização e ao uso feito de conceitos como o de mobilização social. Um exemplo dessa perspectiva pode ser encontrado em Francisco Weffort, O Populismo na Política Brasileira, Rio de Janeiro, Paz e Terra, 1978, cap.6, esp. pp.128 e segs. e 136.

6 Veja-se, por exemplo, Robert C. Tucker (ed.), The Marx-Engels Reader, Nova Iorque, W. N. Norton, 1972, pp.515-516. algo complexa, envolvendo uma dimensão "objetiva" e outra "subjetiva". A dimensão objetiva corresponde, de um lado, à posição sócio-econômica (a subdimensão "vertical" da centralidade objetiva), bem como, de outro, a coisas tais como experiência urbana e amplitude da rede de interação social (a subdimensão "horizontal"), enquanto a dimensão subjetiva diz respeito a aspectos sóciopsicológicos e intelectuais tais como o grau de informação sobre questões políticas e o sentimento — de definição algo imprecisa de desenvoltura e segurança subjetiva nos contatos sociais. ${ }^{7}$ Para nossos propósitos, é importante salientar a maneira pela qual a noção de centralidade se mostra paralela ã de mobilização sócio-política, que também envolve tanto uma dimensão estrutural-ecológica, basicamente referida ao processo de urbanização (com a correspondente intensificação da comunicação social), quando dimensões de natureza sócio-psicológica, intelectual e ideológica, tendo a ver com fenômenos como maior capacidade de "empatia", maior envolvimento sócio-político geral, maior propensão a atitudes politicamente inconformistas etc. Na verdade, uma das críticas que têm sido dirigidas ao uso feito da noção de mobilização social referese à tendência a mesclar, com o emprego de um termo único, dimensões diversas de um processo de grande complexidade, tendência esta que normalmente redunda em se supor que uma

7 A clássica apresentação sintética da teoria da centralidade se encontra em Lester W. Milbrath, Polítical Participation, Chicago, Rand McNally, 1965. Para a definição da dimensão subjetiva do conceito, veja-se p.111. 
direção ou forma específica de ativação política (inconformista, "contestadora", "radical") seja a conseqüência predeterminada das mudanças de tipo estrutural ecológico que conformam o substrato daquele processo.

De outro lado, como é bem sabido — tendo sido elaborado no notável artigo de Pizzorno acima citado $^{8}$-, o modelo da participação política referido a centralidade pode ser contrastado ao modelo da participação baseado na ideia de consciência de classe. Enquanto o primeiro sustenta que a participação é maior quanto maior o grau de centralidade da posição dos indivíduos, o último propõe que "a participação política é maior quanto maior (mais intensa, mais clara, mais precisa) é a consciência de classe"". É de interesse assinalar que, apesar de ambos os modelos destacarem a relação quer da centralidade da posição social ou da consciência de classe com a intensidade da participação política, sem nada afirmarem com respeito à direção desta última (ou seja, seu caráter "radical" ou "conservador"), eles correspondem de perto a duas maneiras de ver o problema da participação política que são moeda corrente fora do campo das ciências sociais e que se interessam sobretudo precisamente pela direção da participação. Elas poderiam designar-se como o modelo da "participação divergente" e o da "participação convergente". O primeiro corresponderia a uma

8 Pizzomo, "Introduzione", op. cit.

9 Ibidem, p. 261. concepção difundida da política ideológica, na qual partidos e movimentos políticos se distribuiriam claramente ao longo de um eixo esquerda-direita e apelariam a frações ideologicamente orientadas do eleitorado (ou da população em geral) que se ajustariam â estrutura das classes sociais. Já o segundo envolve uma concepção idealizada e conservadora do processo político na qual, â medida que os indivíduos sejam cabalmente mobilizados e venham a se tornar sofisticados e "racionais" na avaliação daquele processo, caberia esperar que eles viessem a se tornar também cada vez mais integrados ao sistema sócio-político, prontos a apoiarem os "verdadeiros interesses da nação" 10 .

Pois bem. Diferentemente do mero contraste entre os modelos da centralidade e da consciência de classe, os padrões e formas de participação política deparada no desenrolar do processo de mobilização parecem exigir, para sua adequada explicação, uma articulação relativamente complexa daqueles dois modelos que: 1) corrobora a relevância explicativa do conceito de mobilização sóciopolítica, destacando uma forma específica de associação entre as dimensões estrutural-ecológica e intelectual-psicológica (ideológica) daquele conceito tal como se traduzem em termos das dimensões de "centralidade"; 2) permite ter em conta não apenas a intensidade da

10 Ilustração exemplar dessa perspectiva se tem na mensagem dirigida pelo presidente Ernesto Geisel ao Congresso brasileiro em março de 1976, onde a possibilidade da existência de partidos políticos "autênticos" no Brasil é remetida a um mo- mento futuro, em que o país venha a ter um eleitorado composto de cidadãos "conscientes, racionais e sociabilizados". 
participação política, mas também sua direção conformista ou inconformista. Concretamente, a proposição básica é a de que os fatores correspondentes às diferentes dimensões da noção de centralidade exercem um papel causal não apenas diretamente com respeito à participação política (ou especificamente eleitoral), mas também ao condicionarem, em ampla medida, as probabilidades de que o modelo de consciência de classe possa ele próprio atuar sobre aquela participação. Vejamos como se pode desdobrar analiticamente essa proposição.

Se tomamos as duas subdimensões "objetivas" da noção de centralidade (a vertical, que diz respeito a posição sócio-econômica, e a horizontal, que diz respeito sobretudo a experiência urbana), podemos ver que os limites extremos de posições altamente "periféricas" ou altamente "centrais" correspondem respectivamente aos estratos baixos rurais e aos estratos altos urbanos. Pareceria adequado supor que os representantes dessas posições extremas deveriam situar-se também em pólos opostos no que se refere a opiniões e inclinações políticas, com os últimos exibindo alto grau de conservadorismo e apego ao status quo e os primeiros, alto grau de insatisfação frente a um sistema que os marginaliza de diversas maneiras. Sabidamente, porém, tal suposição seria equivocada no que diz respeito aos estratos baixos rurais. Pois, neste caso, a condição objetivamente marginal ou periférica se encontra com freqüência associada a uma atitude geral de diferencia e a formas de lealdade de tipo clientelístico ou interclasses, traços estes que favoreceriam antes propensões conformistas. Nas áreas rurais ou semi-rurais, assim, seria de esperar que maiores freqüências de inclinações inconformistas viessem a encontrar-se em níveis intermediários da estrutura social, suficientemente favorecidos sócio-economicamente para escapar às limitações intelectuais e psicológicas próprias da condição consistentemente marginal ou periférica, mas não a ponto de que os vested interests relativamente ao sistema existente prevaleçam de vez na determinação de suas opiniões — ou seja, não tanto que estas sejam inteiramente determinadas em direção conservadora, segundo o modelo da consciência de classe. Tal modelo teria melhores condições de operar nas demais categorias que se podem distinguir, os estratos altos rurais e os diversos níveis da estrutura social urbana. Nestes, teríamos fatores diversos de centralidade objetiva - seja a posição sócio-econômica favorável ou os estímulos e a intensidade de comunicação próprios do meio urbano, ou ambos - produzindo resultados em termos de abertura psicológica e acesso a informação que contrastam em graus variados com a contrapartida subjetiva da condição de marginalidade consistente e permitem, na mesma medida, a determinação das opiniões e do comportamento político pela consideração do interesse próprio, isto é, segundo o modelo da consciência de classe. A qualificação contida na expressão "em graus variados" é importante, porém, pois mesmo o ambiente dos maiores centros urbanos (particularmente num contexto de intensa migração rural) não está isento da presença de marginalidade objetiva e subjetiva e de seu 
séqüito de desinformação, deferência e conformismo. Na verdade, um quadro adequado dos processos em jogo revelaria, no ambiente urbano como no rural, um limiar de participação social geral e envolvimento intelectual-psicológico aquém do qual teríamos conservadorismo por falta de atuação dos mecanismos associados à consciência de classe e além do qual teríamos ou inconformismo ou conservadorismo pela atuação desses mecanismos - com a importante reserva adicional quanto à forma incipiente ou rudimentar que tal atuação pode assumir.

Assim, o esquema de interpretação proposto se afasta do modelo da "participação convergente" (com a afinidade deste relativamente ao modelo da centralidade) por pretender ler na evidência pertinente que, à medida que se neutralizem os fatores de marginalidade subjetiva, teremos não a tendência à expressão de valores consensuais, mas antes a expressão de interesses correspondentes às várias posições na estrutura social, ou às várias classes sociais. Mas ele se afasta também do modelo da "participação divergente" e do mero recurso ao modelo da consciência de classe, na medida em que reconhece a existência e o vigor dos fatores de marginalidade subjetiva e de mecanismos que bloqueiam a tomada de consciência do caráter não igualitário da estrutura social, mecanismos estes que atuam segundo os padrões previstos pelo modelo da centralidade.

\section{III}

Voltemos-nos agora para o tema dos partidos políticos no Brasil. O período que vai de 1945 a 1964 propicia um contraste com a situação atual ao qual se faz necessário recorrer como ponto de partida, mesmo porque alguns dos tópicos repetidamente presentes no discurso político brasileiro de nossos dias a respeito dos partidos políticos referem-se inicialmente aos partidos que então existiram.

Um desses tópicos, talvez o favorito e certamente o de maior alcance do ponto de vista de uma avaliação como a que aqui se procura fazer, diz respeito ao suposto "amorfismo" que caracterizaria a estrutura partidária brasileira daquele período. Com efeito, amiúde se sustenta que os partidos então existentes não seriam senão criações artificiais, sem bases sociais autênticas e sem diferenciação ideológica nítida. Tais características seriam a contrapartida ou o reflexo de traços que marcariam o próprio eleitorado, o qual é visto, em geral, como politicamente amorfo e inconsistente, pouco envolvido ou interessado em questões políticas e destituído de verdadeira "consciência política". Em última análise, segundo essa visão, os partidos se distinguiriam apenas pelo grau em que, através de expedientes mais ou menos espúrios, se mostravam capazes de atrair diferentes parcelas daquele eleitorado politicamente alheio e manipulável. Como avaliar tal diagnóstico, e que relevância tem para os problemas de pós-64?

O sistema partidário existente entre 1945 e 1964 chegou a incluir 13 partidos, de importância muito variada na cena política do 
país. 1945 marca o fim da ditadura de Getúlio Vargas, que exercera o poder supremo desde 1930. Mas é da iniciativa do próprio Vargas que brotam, na transição para a fase democrática da vida brasileira que então se inaugura, dois dos mais importantes partidos do período;

o Partido Social Democrático (PSD) e o Partido Trabalhista Brasileiro (PTB).

No PSD se organizam os interesses que gravitavam em tomo da máquina político-administrativa da ditadura varguista. Em especial, ele congrega homens que haviam atuado como interventores de Getúlio Vargas junto ao governo dos estados, bem como - com variações regionais — as lideranças de bases rurais que haviam tradicionalmente ajudado a compor a estrutura clientelística da política brasileira. De orientação conservadora, mas afeito ao jogo do poder, o pessedismo, que tem seu principal núcleo em Minas Gerais, rapidamente adquire a imagem que viria marcar o político mineiro e, de certa forma, impregnar de maneira negativa a própria ideia de política no Brasil: a do político hábil, pragmático e pouco escrupuloso.

O PTB, por seu turno, organiza-se com o objetivo de atrair as massas trabalhadoras urbanas em expansão, manejando como trunfo a imagem de "pai dos pobres" adquirida por Vargas em conexão com suas iniciativas na área trabalhista, especialmente a legislação do trabalho introduzida como parte da estrutura corporativa montada durante o Estado Novo (1937-45). Essa estrutura se mantém intacta posteriormente, atrelando os sindicatos de trabalhadores ao
Ministério do Trabalho e compondo com os quadros petebistas as alavancas de controle político do movimento trabalhista por Getúlio Vargas e figuras a ele ligadas — especialmente João Goulart, político gaúcho que se afirma no cenário político nacional como ministro do Trabalho de Vargas no mandato presidencial que este obtém nas umas em 1950. Em termos gerais, o período que vai de 1945 a 1964 pode ser descrito como correspondendo ao controle do processo político brasileiro pela coalização formada por PSD e PTB.

O principal partido a opor-se a tal coalizão é a União Democrática Nacional (UDN), que se configura em tomo dos líderes da oposição liberal ao regime varguista ao final do período ditatorial. Atraindo empresários, profissionais liberais e classes médias urbanas, a UDN exerce no período um papel marcado por grande ambigüidade; sendo originária e retoricamente liberal e representando o porta-voz de estridente oposição moralista ao condomínio PSDPTB, não deixou, porém, de favorecer e estimular a intervenção dos militares no processo político sempre que tal intervenção pareceu servir aos interesses do partido, e próceres udenistas vieram a ser alguns dos nomes civis mais expressivos a integrarem o governo surgido do movimento político-militar de 1964.

Dentre vários outros partidos ou movimentos de expressão meramente regional, merece destaque o Partido Social Progressista (PSP), controlado por Adhemar de Barros e de significativa presença em São Paulo, o principal estado da Federação. Singulariza-se o PSP por combinar um apelo marcadamente populista com a montagem de 
eficiente máquina eleitoral baseada na manipulação de prebendas facultada pelo acesso ao poder estadual. O populismo paulista tem, porém, no período, outra vertente de muito maiores consequiências para o jogo político nacional, a saber, o movimento constituído ao redor de Jânio Quadros. Ascendendo me teoricamente, em larga medida à margem da estrutura partidária, desde sua eleição para a Câmara Municipal de São Paulo, 9uadros viria a atingir a Presidência da República e a ter participação importante nos eventos que culminaram no levante militar de 1964. Seu apelo político baseava-se numa imagem de autenticidade popular de cunho apolítico ou mesmo antipolítico, bem como numa veemente mensagem de moralização administrativa.

Precisamente o êxito das lideranças e movimentos populistas, bem como o da própria coalizão PSD.PTB (a expressar, de certa forma, o acoplamento entre massas supostamente manipuláveis e elites que lhes são heterogêneas por sua origem social, acoplamento este que caracterizaria o populismo latino-americano em geral), serve como ponto focal das denúncias de amorfismo e inconsistência acima mencionadas com respeito ao eleitorado e aos partidos. Seja qual for a parcela de verdade contida em tais denúncias, que poderemos apreciar melhor adiante, cumpre assinalar a existência, já no período examinado, de indícios que se contrapunham com nitidez a elas. Assim, há, por um lado, evidências que mostram, durante o curto período em que o Partido Comunista Brasileiro pôde atuar legalmente e participar abertamente do processo eleitoral (até 1947), a nascente "ideologização" das camadas populares do eleitorado brasileiro em seus setores "de ponta". Dados analisados por Azis Simão relativamente ao comportamento eleitoral dos trabalhadores da cidade de São Paulo nas eleições de 1947 para a Assembléia Legislativa paulista revelam que, enquanto o PCB e o PTB obtinham conjuntamente uma ampla proporção do voto trabalhador, o PCB tinha claramente a preferência dos trabalhadores industriais: ele recebia proporção muito maior dos votos apurados nos distritos eleitorais que incluíam maiores porcentagens de trabalhadores industriais e quê se localizavam nas regiões da cidade que haviam sofrido maior penetração industrial, exibindo, em muitos casos, uma tradição industrial proveniente de finais do século passado. ${ }^{11}$

Mas também com respeito ao PTB, apesar de sua inspiração varguista e dos desígnios de manipulação normalmente imputados a suas lideranças, podemos encontrar indícios que veio em direção diferente. Assim, o partido cresce consistentemente em sua penetração durante o período considerado, evidenciando que sua mensagem — ou pelo menos sua imagem — encontra certo tipo de ressonância no eleitorado que não se poderia descartar sem mais. Além disso, porém, como mostraram análises como as de Gláucio Soares e Antônio Octávio Cintra, os correlatos dessa penetração em termos tanto dos estratos sociais em que ela ocorre

11 Aziz Simão, "O Voto Operário em São Paulo", em Anais do I Congresso Brasileiro de Sociologia, São Paulo, Sociedade Brasileira de Sociologia, 1955. 
diferencialmente quanto das percepções e opiniões políticas — estão longe de ajustar-se ao que se presumiria com base na tese do "amorfismo", ainda que comportem ambigüidades. ${ }^{12} \mathrm{Na}$ verdade, a apreciação global que parece adequada extrair das evidências pertinentes é congruente com a tese de Celso Furtado a respeito da "dialética do populismo", segundo a qual os mecanismos acionados com intuitos manipuladores pelas lideranças populistas terminam por configurar-se, em medida significativa em fatores de real mobilização política dos setores populares. ${ }^{13}$ E não é outra a razão de que, realizado o movimento políticomilitar de 1964 como reação às ameaças percebidas num quadro em que avulta precisamente aquela mobilização, o regime autoritário tenha pouco depois julgado conveniente extinguir pela força os partidos então existentes, buscando substituí-los por uma estrutura partidária mais apta a servir aos seus propósitos.

\section{IV}

Essa extinção se dá em 1965, com o Ato Institucional n. 2. Sua razão imediata foi a vitória obtida, naquele ano, por candidatos do PSD

12 Vejam-se, por exemplo, Gláucio Ary Dillon Soares, "The Political Sociology of Uneven Development in Brazil", em Irving L. Horowitz (ed.), Revolution in Brazil, Nova Iorque, E. P. Dutton, 1964; e Antônio Octávio Cintra, "Partidos Políticos em Belo Horizonte: Um Estudo do Eleitorado", Dado" n? 5, 1968.

13 Veja-se Celso Furtado, Dialética do Desenvolvimento, Rio de Janeiro, Fundo de Cultura, 1964, pp.83-85. para o governo dos importantes estados de Minas Gerais e da Guanabara. Através dos dispositivos legais então implantados, o governo impôs ao país o bipartidarismo, congregando na Aliança Renovadora Nacional (ARENA) as forças de apoio políticoparlamentar ao regime e forçando, pelo rigor das exigências para a constituição de novos partidos, os políticos oposicionistas que haviam sobrevivido aos expurgos e cassações a se agruparem num único partido de oposição, o Movimento Democrático Brasileiro (MDB).

Cabe indagar das razões dessa opção pelo bipartidarismo. Elas certamente incluem a visão idealizada do bipartidarismo existente em alguns dos países ocidentais mais avançados economicamente, visão esta que pode ser considerada como integrando o ideário liberaldemocrático a que os mentores do regime de pós-64 jamais chegaram a renunciar abertamente — e que aparentemente impediu a opção por um sistema unipartidário, cuja imposição teria então sido possível. Por outro lado, tal como realizada, a imposição de um bipartidarismo formal, se salvava as aparências quanto ao ideário liberal verbalmente professado pelo regime, parecia ter condições de redundar num unipartidarismo de fato. Expurgadas as hostes oposicionistas das lideranças mais aguerridas e eleitoralmente vigorosas do populismo anterior; obtida a coesão do dispositivo político partidário governamental através da atuação conjugada do estabelecimento de linhas nítidas de separação entre os "pró" e os "contra", da manipulação da máquina do governo e do recurso a 
instrumentos de pressão ou coerção aberta; empreendido, através de campanhas e iniciativas de diversos tipos (inclusive a introdução do ensino de "educação moral e cívica" em todos os níveis do sistema educacional), o esclarecimento público contra a corrupção e os artifícios demoníacos de movimentos e figuras de inspiração alheia ã "índole do povo brasileiro"; as condições pareciam criadas para que o regime viesse a contar, a curto prazo e de maneira estável, com os frutos eleitorais de políticas desenvolvidas com seriedade e eficiência nos diversos campos de atuação governamental. E os votos dados ao partido do governo num quadro de disputa bipartidária seriam fator importante de legitimação, inclusive — e talvez sobretudo — no cenário internacional.

Como quer que seja, a implantação do bipartidarismo revelou-se, a posteriori, uma decisão de importantes conseqüências para a dinâmica do regime, embora certamente não as conseqüências previstas por ele. Ela redundou, com efeito, numa simplificação drástica das opções e do universo defrontado pelo eleitor ao tomar sua decisão eleitoral. Do ponto de vista da consciência política dos estratos populares, tal simplificação se superpôs "convenientemente" ao simplismo das percepções e opiniões políticas - com a conseqüência de que, passado o momento inicial de perturbação e surgindo as oportunidades para que o partido de oposição pudesse dirigir ao eleitorado uma mensagem aguerrida, projetando uma imagem de tonalidades populares, viesse ele a capitalizar eleitoralmente as mesmas tendências que haviam anteriormente produzido o populismo. Facilitada pelo quadro político-partidário bipolar, que passou a fornecer claro molde institucional para contraposições simples como as que se dão na consciência popular entre categorias tais como "ricos" e "pobres", "povo" e "governo", ${ }^{14}$ tal retomada das tendências anteriores se deu em 1974, quando o MDB catalizou pela primeira vez as preferências populares e obteve inequívoca vitória nas eleições para o Senado. Abre-se, a partir daí, nova fase nas manobras institucionais do regime, que buscam agora neutralizar o potencial de mobilização do voto popular com que o MDB passa a contar sobretudo nos centros urbanos, culminando na liquidação forçosa do bipartidarismo e na restauração de uma estrutura multipartidária através de poderosos incentivos legais e políticos.

Do ponto de vista analítico, a imposição do bipartidarismo representou, como os resultados sucintamente descritos sugerem, um experimento' de grande interesse, no qual a própria simplificação artificial das opções permite a cristalização mais clara de certas tendências básicas. Essa cristalização, por outro lado, se dá de maneira a desmentir a tese do "amorfismo" do eleitorado, apesar dos matizes cuja consideração os dados disponíveis a respeito impõem. Examinaremos resumidamente, a seguir, algumas conclusões das

14 Veja-se Fábio W. Reis, "As Eleições em Minas Gerais", em Bolivar Lamounier e Fernando H. Cardoso (org.), 01 Partidos e as Eleições no Brasil, Rio de Janeiro, paz e Terra, 1975, para apresentação de material empírico pertinente. 
análises de tais dados, destacando a "morfologia" do apoio partidário tal como pode ser traçada em termos das dimensões básicas envolvidas na noção de centralidade anteriormente discutida e alguns aspectos político-ideológicos subjacentes à identificação partidária e a sua diferenciação nas diversas camadas sócio-econômicas. As proposições a serem apresentadas referem-se a dados coletados através de surveys executados em quatro cidades por ocasião das eleições de $1976 .^{15}$

A Tabela 1 procura dispor graficamente a maneira pela qual a identificação com um ou outro das partidas existentes em 1976 se distribui pela estrutura social. Comecemos pelos limites inferiores do

15 A análise detida do material correspondente pode ser encontrada em Fábio W. Reis (org.), 011 Partidos e o Regime: A Lógica do Processo Eleitoral Brasileiro, São Paulo, Símbolo, 1978, que foi o primeiro resultado de pesquisa realizada por ocasião das eleições municipais de 1976 nos municípios de Juiz de Fora, MG; Presidente Prudente, SP; Niterói, RJ; e Caxias do Sul, RS. A pesquisa, escutada em colaboração entre o Departamento de Ciências Políticas da UFMG,o Centro Brasileiro de Análise e Planejamento (CEBRAP) o Instituto Universitário de Pesquisas do Rio de Janeiro (IUPERJ) e o Departamento de Ciências Sociais da UFRGS, foi coordenada conjuntamente por Bolivar Lamounier, Olavo Brasil de Lima Júnior, Hélgio Trindade e Fábio W. Reis. Parte do texto que se segue é uma adaptação de minhas contribuições a esse volume: "Classe Social e Opção Partidária: As Eleições de 1976 em Juiz de Fora" e "Conclusão: Em Busca da Lógica do Processo Eleitoral Brasileiro". Além desses capítulos, o volume contém 'ainda os seguintes trabalhos, aos quais se referem todas as menções aos co-autores a serem encontradas adiante: Bolivar Lamounier, "Presidente Prudente: O Crescimento da Oposição num Reduto Arenista"; Olavo Brasil de Uma Júnior, "Articulação de Interesses, Posição SócioEconômica e Ideologia: As Eleições de 1976 em Niterói"; Hélgio Trindade, "A Polarização Eleitoral numa Comunidade Agro-Industrial Moderna"; e Judson de Cew, "A Decisão Eleitoral em Caxias do Sul". sistema que o. esquema sugere, ou seja, aqueles que têm a ver com a fronteira mesma entre a exclusão total e algum grau de participação.. O zero absoluto corresponde aqui à condição de cidadania de segunda classe em que as pessoas se vêem privadas do próprio direito formal ao voto. Os analfabetos são aqueles que mais obviamente se situam nessa condição, já que, no. Brasil, encontram-se legalmente impedidas de votar Assinale-se, porém, que sua exclusão tem conseqüências que veio além da privação da possibilidade de votar: as dadas mostram que mesmo a identificação subjetiva com qualquer das partidas (a simples preferência par qualquer deles) declina de maneira desproporcional entre as analfabetas. Mas é de interesse igualmente ressaltar que as analfabetas eram as únicas nessa categoria. O complexo de fatores que compõe a condição marginal contém outros mecanismos pelas quais novos contingentes das camadas sócio-econômicas inferiores da população só excluídas do sufrágio, tais cama as dificuldades de qualquer ardem para manter regularizada a documentação exigida do votante, que tendem a incidir diferencialmente nas diversas estratos sócio-econômicos, mais marcadamente nas estratos mais baixas. Par outro lado, congruentemente com a visto de que temas maior marginalidade no pólo rural da dicotomia rural-urbano, as dadas mostram que, dentre as quatro cidades estudadas, o. efeito conjunto de analfabetismo e exigências burocráticas quanto a excluir da participação eleitoral é maior em Presidente Prudente, que melhor corresponde ao pólo rural e ande a proporção das que não votam por qualquer razão alcança 31 
por cento da amostra.

Se vamos além e buscamos avaliar as conseqüências da condição periférica ou marginal do ponto de vista do conteúdo da participação, ou de como afeta o apoio a cada um dos partidos, a primeira indagação se refere aos efeitos, nesse sentido, da própria exclusão formal do direito de voto. Alguns dados de Juiz de Fora são especialmente elucidativos a esse respeito. Tomando a renda familiar em categorias que se dispersam desde aqueles que contam com um salário mínimo ou menos por mês até os que contam com mais de 20 salários mínimos, vê-se que as frequiências dos que deixam de votar por qualquer razão diminuem quase linearmente nada menos de 34 por cento entre os primeiros a 11 por cento entre os últimos. Isso contrasta agudamente com a variação dos votos dados à ARENA, que crescem de 29 a 54 por cento entre as mesmas categorias, enquanto os votos dados ao MDB permanecem praticamente constantes ao redor da proporção média de 28 por cento. Tal padrão indica de maneira muito clara que a perda do sufrágio se daria sobretudo em detrimento do MDB, excluindo da participação contingentes significativos de eleitores potenciais daquele partido.

As coisas são mais complexas, porém, pois, além da exclusão formal do direito de voto, os traços intelectuais e psicológicos que se associam à posição periférica de setores dos estratos baixos tendem com freqüência, na verdade, a resultar em maior incidência de preferência pela ARENA. Começando pelo lado rural ou semi-rural das cidades estudadas, isso se verifica em Presidente Prudente, como destaca Bolivar Lamounier, entre as camadas muito baixas do eleitorado, quer se trate de analfabetos; daqueles que se situam em posição especialmente desvantajosa do ponto de vista ocupacional ou dos que declaram não contar com serviços básicos em seus locais de residência: em todos esses casos, aumenta a taxa de identificação com a ARENA, tal como ocorre nos níveis mais altos da estrutura social, entre empregadores e administradores. Mas o mesmo padrão se depara também no lado urbano do sistema. Em Niterói, por exemplo, antiga capital do Estado do Rio de Janeiro, encontram-se taxas igualmente altas de preferência pela ARENA nas posições consistentes quanto aos níveis de renda e educação: quer se trate de posições consistentemente altas ou consistentemente baixas, as proporções de votos "arenistas" aumentam quando comparadas com as que se dão nas posições inconsistentes ou intermediárias aumentam, vale dizer, nas posições extremas da estrutura social, como assinala Olavo Brasil de Lima Júnior. 
Tabela 1

DIMENSŐES DE "CENTRALIDADE" E DISPOSIÇÕES POLITICO-ELEITORAIS ULEICOES BRASILEIRAS DE" E DIS, SÃO PAUE SURVEYS EXECUTADIS RIO GRANDE DO SUL)

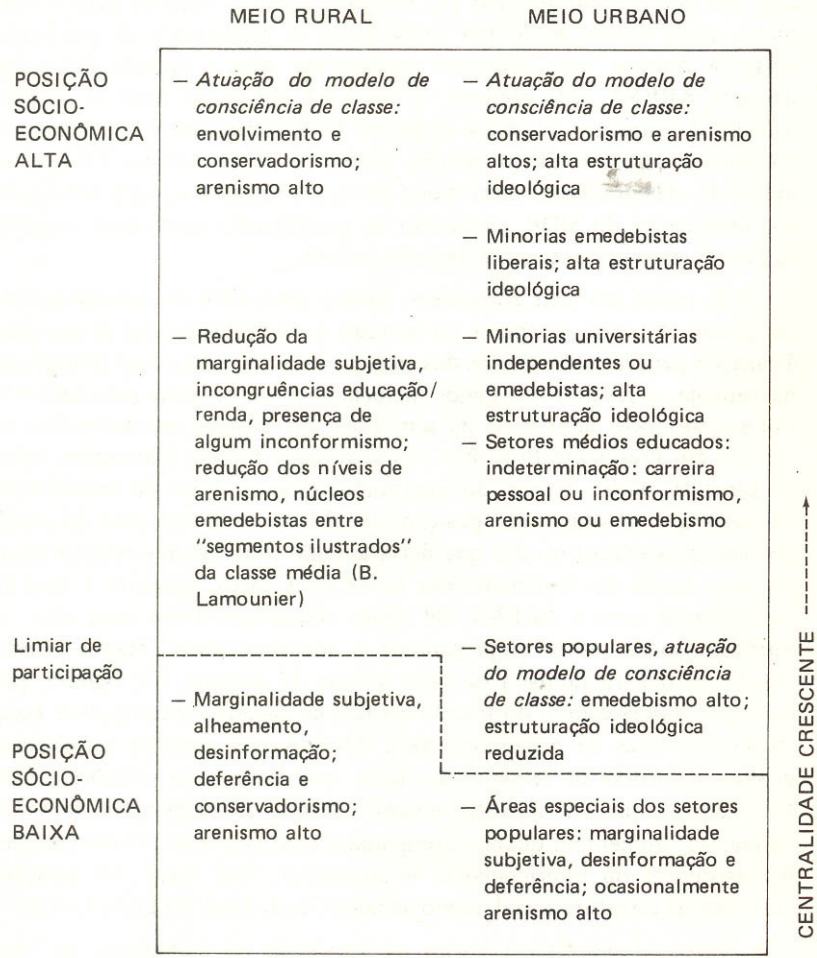

CENTRALIDADE CRESCENTE

Parece desnecessário insistir na ligação de tal incremento de "arenismo" nos níveis mais baixos com a carência de informação e o distanciamento psicológico face ao mundo político que diversos aspectos dos dados em questão revelam existir no extremo inferior da estrutura social. Assim, a análise dos dados de Juiz de Fora revela a maneira pela qual a falta de informação condiciona, nos estratos mais baixos da população, a ocorrência bastante frequiente (muito mais freqüente do que as que se observam à medida que se sobe nos níveis de renda) de uma imagem positiva da ARENA como sendo a favor do voto direto para a escolha do presidente da República e demais autoridades executivas. Contudo, os dados de Niterói comprovam inequivocamente a ligação mencionada, pois mostram que a proporção de "arenistas" entre os eleitores de baixo nível educacional é tanto maior quanto maior o desinteresse pela política, enquanto precisamente o oposto se dá entre os "arenistas" de nível educacional alto. À parte o alheamento e o erro puro e simples das informações de que dispõem os setores em questão sobre os partidos, é bastante claro que a explicação para o padrão observado se encontra na atitude de deferência que ajuda a compor a síndrome da marginalidade subjetiva. Nesta perspectiva, o fato mesmo de que se tenha alto "arenismo" nos níveis sócio-econômicos mais altos se torna um fator favorável ao seu aparecimento também em certas áreas dos extremos inferiores.

Se deixamos a zona de fronteira entre participação e exclusão em que nos movemos até aqui, o aspecto a assinalar inicialmente se refere a posições que, na escala bidimensional de centralidade objetiva, podem ser vistas como um patamar relativamente incipiente de participação e envolvimento, mas ainda assim suficientemente distante da condição de marginalidade subjetiva para ocasionar o surgimento de certo grau de inconformismo. Refiro-me aos estratos 
intermediários do setor rural ou semi-rural do sistema, que se ilustram com o que Bolivar Lamounier designa como os "segmentos ilustrados" da classe média de Presidente Prudente, onde parecem concentrar-se os núcleos de penetração do MDB no ambiente maciçamente pró-ARENA daquela cidade. Os dados analisados por Lamounier indicam que esses redutos oposicionistas minoritários correspondem sobretudo a situações caracterizadas por certa incongruência entre o nível de escolaridade relativamente alto com que contam as pessoas e sua condição econômica, particularmente seu nível de renda, comparativamente insatisfatório. Por outro lado, Lamounier sugere que o padrão de distribuição social das preferências partidárias deparado em Presidente Prudente, com a penetração intersticial do MDB nessas posições da estrutura social, seria próprio das condições que caracterizam, de maneira mais geral, o que ele chama de "metrópoles periféricas", entre as quais se poderia incluir mesmo uma grande cidade como Salvador, capital do Estado da Bahia. Apreciada à luz do uso aqui feito das noções de "central" e "periférico", essa sugestão acena com a possibilidade de se complicar a dimensão "horizontal" do esquema proposto, que passaria a incluir mais que a mera oposição entre rural (ou semi-rural) e urbano.

O ponto seguinte a destacar diz respeito às variadas situações em que se daria a atuação do modelo da consciência de classe. Naturalmente, a pretensão de apreender a consciência de classe através de dados como os de que aqui se trata defronta de imediato o velho problema da oposição entre classes como grupos sociais efetivos e os estratos que se podem distinguir ao se submeterem dimensões variadas (escolaridade, renda familiar) a cortes mais ou menos arbitrários. Cabe fazer, entretanto, duas ponderações. Em primeiro lugar, a questão de saber até que ponto existe a possibilidade de se falar de classes sociais efetivas à respeito de certas categorias que se podem distinguir na estrutura social brasileira é precisamente uma das questões substantivas de interesse a que se dirigem estudos como os que procuram relacionar o processo eleitoral-partidário e o regime autoritário, seu significado e suas perspectivas.Em segundo lugar, sem negar a importância da questão metodológica mas sem pretender dirigir-se a ela, a suposição a que aqui se recorre é apenas à de que a forma (ou a direção) de certas relações básicas, como as que se dão entre a identificação partidária e "posições sociais"; mais ou menos arbitrariamente distinguidas, ganha significado e coerência se tais posições são vistas como a tradução ou a expressão, embota defeituosa e longínqua, de classes sociais subjacentes.

Se isso é aceitável, a primeira observação de cunho substantivo que cabe fazer reitera, por um aspecto, o que se acaba de dizer: nas diversas posições da estrutura social em que se pretende encontrar a atuação do modelo de consciência de classe (setor rural alto, setores urbanos baixo e alto), tal pretensão se dirige especificamente à forma das relações deparadas entre posição social e opção partidária. Assim, é possível apontar alto "arenismo" nos estratos altos da população de Presidente Prudente. Igualmente, nas demais cidades se pode 
observar clara correlação positiva (se se prescinde por um momento de algumas complicações a respeito da variável educação, a serem mencionadas adiante) das preferências "arenistas" com indicadores de posição social tais como renda, ocupação e identificação subjetiva com determinada "classe", correlação esta que expressa o predomínio do MDB nos estratos baixos e da ARENA nos estratos altos.

Indo além da forma assim exibida pelas relações, porém, não se pretende que os dados permitam dizer que as variações na opção partidária segundo as posições sociais podem ser sempre postas em correspondência com conteúdos ideológicos que manifestem o tipo de afinidade com cada posição particular que se esperaria da afirmação plena do modelo de consciência de classe. Ao contrário, o esquema geral de interpretação aqui utilizado, baseado na combinação do modelo da centralidade com o modelo da consciência de classe, pretende propor que os mecanismos associados à centralidade objetiva e subjetiva condicionam não somente a possibilidade de que atue ou não a modelo de consciência de classe (como no que se refere aos fatores que bloqueiam a manifestação desta na condição propriamente marginal), mas também o grau em que atuará nos casos em que efetivamente atue. Por outras palavras, mesmo ultrapassado o limiar que separa a participação da exclusão "absoluta" (isto é, uma vez que se tenha deixado a condição de marginalidade total e penetrado, em alguma medida, o universo sócio-político que conta), os fatores de centralidade continuam a "corrigir" — ou a "entortar", se preferir - a operação do modelo de consciência de classe. Assim, nas condições brasileiras, mais centrais a posição global (ou seja, mais urbana, mais alta), maior possibilidade de "intensidade" e "clareza" da consciência de classe e para os setores populares, a vigência plena, do modelo de consciência de classes dependia da eliminação dos resíduos de marginalidade subjetiva (acentuada precariedade ao acesso à educação, hábitos de referência, privatismo etc.) que acompanham sua condição objetiva.

Tal proposição de corrobora de maneira clara nos graus variados de estruturação ideológica que os dados revelam existir junto a diferentes categorias da população das cidades estruturadas. Assim, se toma a dimensão "vertical" da centralidade correspondente à oposição sócio-econômica, tanto no pólo mais urbano como no mais rural do conjunto de cidades se pode observar muito maior estruturação ideológica nas camadas altas do que nas camadas baixas da população. As primeiras exibem não apenas maior propensão a estarem conscientes e informadas das questões que agitam a cena política, mas também a adotarem posições em principio coerente sobre as diversas questões. Além disso, elas dão tradução mais "adequada" a tais posições em que se refere à identificação ou preferência partidária — ou seja, os mais "inconformistas" tendem em maior medida a apoiar o MOB nas camadas altas (ainda que sejam ai minoritários) do que nas camadas baixas, o mesmo se dando com o apoio à ARENA por parte dos mais "conformistas", Por outro lado, se toma a dimensão "horizontal" da centralidade, indícios 
bastante claros sugerem a operação de um padrão geral análogo, a evidenciar, independentemente da posição sócio-econômica, maior estruturação do universo político-ideológico no pólo urbano do que no pólo rural.

Ressalte-se que tal padrão geral, em atuação tanto no plano horizontal quanto no vertical, dá-se não obstante o fato de que seja possível observar igualmente nos dados indícios de que a natureza específica das questões de que se trate tem, por si mesma, consequiências para a opção por um partido 04 outro. Assim, nos estratos sócio-econômicos mais baixos, certas questões mais "próximas", ou que parecem afetar mais diretamente as condições da vida cotidiana das pessoas, parecem também ligar-se mais claramente à opção partidária do que as "remotas" questões de natureza políticoinstitucional (ou seja, aquelas que têm a ver sobretudo com a própria natureza autoritária da vida política brasileira da atualidade, incluindo itens como o controle militar do processo político, os instrumentos excepcionais e arbitrários em poder do Executivo, as restrições impostas às campanhas eleitorais etc.). Para ilustrar, isso se pôde constatar em especial com respeito a um item aparentemente de alta sensibilidade para a consciência popular: o da avaliação das condições da assistência médica acessível localmente, o qual mostra forte relação com a opção partidária, nos estratos populares, no sentido que se esperaria, ou seja, avaliações negativas se associam com a opção pelo MDB e avaliações positivas com a opção pela ARENA. Constatações desse tipo apontam, naturalmente, para a existência de formas diferenciais de se processar a estruturação do universo sócio-político nas diferentes classes ou camadas da população, bem como nos contextos sociais diversos representados por ambientes rurais ou urbanos. Mas, obviamente, este é um dos aspectos ou dimensões da questão geral de que aqui se trata, e tais formas diferenciais de estruturação ideológica se vinculam com o problema do "grau", "intensidade" e "clareza" - para tomar ainda uma vez as expressões de Pizzorno - da consciência de classe. Por outras palavras, a consciência de classe irá crescer precisamente em função da medida em que exista a capacidade de integrar a percepção ou definição das questões de natureza diversa e a posição assumida com respeito a cada uma, de sorte que se possa chegar a uma visão dos interesses gerais da classe que não apenas leve a que se tenha opinião quanto às questões de diferentes tipos ou níveis, mas também oriente e permita fundar coerentemente tais opiniões. Ora, os dados revelam que essa capacidade existe em maior grau, em geral, nas posições mais altas e "centrais".

Concluamos esta apresentação sumária das constatações das análises em questão com breve referência às categorias mencionadas na Tabela 1 como contando com alta escolaridade, seja os "setores médios educados" ou as "minorias universitárias". Com efeito, a consideração do grau de educação formal dos eleitores, sobretudo em conjugação com as faixas de idade, permite apreciar interstícios especiais que se compõem na estrutura social. Naturalmente, a educação se encontra correlacionada com variáveis como renda 
familiar, e o nível educacional pode ser tomado

Como indicador de posição social geral. Apesar disso, seus efeitos tendem a ser peculiares por diversas razões, tais como: 1) a educação formal traduz-se imediatamente em graus diversos de sofisticação intelectual, de relevância direta para as opiniões e atitudes políticas; 2) ela se articula de maneira relativamente complexa com as aspirações quanto a condições gerais de vida e com a avaliação do êxito na realização de tais aspirações, articulação esta que é condicionada pela idade dos eleitores; 3) sobretudo no nível universitário, a experiência educacional tende a corresponder à exposição direta a um ambiente singularmente sensível politicamente, a qual tende a dar-se também em determinada faixa de idade. Como quer que seja, os dados aqui considerados indicam que o impacto específico do nível educacional sobre o grau de conformismo ou inconformismo político assume formas algo sinuosas e instáveis. $\mathrm{Na}$ atualidade, contudo, parece predominar a tendência de que a educação opere como fator de conformismo político e de apoio ao partido do governo, tendência esta que, com exceção do setor universitário, se afirma de maneira especialmente marcada entre os jovens. Isso representa, por ambos os aspectos, a inversão de tendências observadas no passado, e parece dever interpretar-se sobretudo como conseqüência de expectativas ocupacionais mais favoráveis para os setores educados da população criadas pela expansão econômica que o regime autoritário se mostrou capaz de assegurar por algum tempo. Assim, feitas as devidas e importantes reservas quanto à parcela da juventude diretamente envolvida no clima político das universidades, o empenho politicamente desmobilizador que caracteriza o regime vigente parece ter tido razoável êxito junto aos jovens educados, substituindo, ao que tudo indica, cogitações sociais e políticas por preocupações de carreira pessoal em muitos deles. ${ }^{46}$

\section{V}

Os padrões examinados, ajustando-se com clareza, por um lado, às proposições acima formuladas sobre a articulação entre os modelos da centralidade e da consciência de classe, mostram-se, por outro lado, grande mente relevantes do ponto de vista das condições gerais dos regimes autoritários e das feições por eles assumidas. Eles exibem, em primeiro lugar, algumas das ameaças inerentes à política ideológica frente às quais os regimes autoritários representam, do ponto de vista das forças conservadoras, uma reação que cabe ver como mais ou menos "oportuna" ameaças a serem encontradas sobretudo nas formas emergentes de consciência de classe que marcam as disposições e o comportamento político dos estratos trabalhadores da população dos centros urbanos. Além disso, contudo, eles exibem igualmente, ao lado das fontes "naturais" de apoio de que tais regimes dispõem nas classes médias e altas, as

46 Alguns dos dados contrastantes a respeito do papel político da escolaridade são examinados em Fábio W. Reis, "Classe Social e Opção Partidária", op. cit. 
fontes potenciais de apoio com que podem contar — através de algum tipo de manipulação ideológica ou de vínculos clientelísticos — entre as camadas mais baixas e mais estritamente "marginais" dos setores populares, tanto no campo quanto nas cidades. Ademais desse fator nitidamente "diferencial" de apoio, entretanto, é importante salientar, no que se refere ao Brasil, o caráter emergente e altamente limitado da operação do modelo de consciência de classe mesmo junto li "vanguarda" urbana dos estratos populares. Os dados acima considerados, com efeito, mostram com clareza que mesmo os membros dessa "vanguarda" apresentam um grau grandemente precário de estruturação ideológica em sua percepção do universo sócio-político. Tal estado de coisas provavelmente é o que responde pela ocorrência aparente de formas pouco plausíveis de se relacionarem os propósitos e os efeitos reais de certas políticas perseguidas pelo regime autoritário brasileiro: de fato, há indícios de que $\mathrm{O}$ regime desfrutou de maior aquiescência, pelo menos de natureza passiva, enquanto afirmou de maneira self-righteous sua face mais dura do que quando começou a manifestar preocupação em decorrência de problemas ligados à coesão interna do sistema de poder que não podemos examinar aqui - com temas tais como abertura política e redistribuição econômica.

Ao fim e ao cabo, a realidade no que diz respeito às percepções e disposições populares parece consistir numa condição ambígua em que, embora o inconformismo seja real, de caráter consistente (ainda que sobre a base de contraposições antes simplórias, como a que se estabelece entre "ricos" e "pobres", anteriormente mencionada) e persistente o bastante no longo prazo de sorte a tornar o populismo uma fatalidade se alguma forma de abertura política conseqüente; vier efetivamente a ocorrer, ele é também de natureza desinformada e não ideológica e as inclinações oposicionistas da maioria parecem destituídas de conteúdo em termos de questões específicas de qualquer natureza, bem como da percepção de praticamente qualquer articulação entre questões políticas diversas. Isso redunda, naturalmente, em que com frequiência inexiste a percepção da relevância política de qualquer questão — ou, do ângulo oposto, da relevância da política para as condições da vida cotidiana. No momento, como se indicou acima, o governo brasileiro se empenha em restaurar uma estrutura multipartidária capaz de lhe permitir manter o controle do processo eleitoral na complicada dinâmica em que se desdobra o regime autoritário. Toda uma complexa estratégia, envolvendo mesmo a reabsorção de lideranças do período populista proscritas em 1964, foi posta em prática com o objetivo de romper a unidade oposicionista do antigo MDB e garantir simultaneamente a viabilidade da linha partidária de apoio ao regime no Legislativo e fora dele. Embora bem-sucedida em ampla medida, essa estratégia sofreu tropeços importantes, destacando-se o surgimento não previsto do Partido dos Trabalhadores em torno de novas lideranças sindicais paulistas e a recente reincorporação ao partido sucessor do MDB (o Partido do Movimento Renovador Brasileiro, PMDB) do Partido Popular (PP), que congregou fugazmente setores liberais e que os 
mentores do regime e da reformulação partidária esperaram viesse a representar um partido de centro e um setor oposicionista confiável, com que o governo pudesse vir a negociar e a compor-se. A situação atual é de grande fluidez, a qual é agravada pelo caráter de reação espasmódica aos eventos que marca muitas das medidas adotadas pelo regime, e pode evoluir em direções diversas a partir das importantes eleições (para cargos que vão desde governadores de Estados e senadores até vereadores) previstas para novembro próximo ..

Como quer que seja, parece claro que indagações como as suscitadas acima têm conseqüências importantes para os prospectos defrontados pelos regimes autoritários de virem a ser capazes de legitimar-se e dar solução ao problema de sua eventual estabilização ou institucionalização. Seria certamente instrutivo, por exemplo, comparar, à luz de tais indagações, as vicissitudes da política autoritária em países como o Brasil e a Argentina, que, do ponto de vista global, apresentam importantes diferenças quanto à mobilização e à ativação políticas dos setores populares. ${ }^{47}$ Além disso, uma

47 Isso transparece com muita clareza, por exemplo, se comparam dados argentinos de um survey realizado em 1965 (apresentados em Jeane Kirkpatrick, Leader and Vanguard in Mass Society, Cambridge, MIT Press, 1971, p. 159) com os dados de um survey sobre "Representação e Desenvolvimento no Brasil" executado em 1973 por Philip Converse, Peter McDonough e Amaury de Souza junto à população do "núcleo" sócioeconomicamente mais desenvolvido do país (os quais foram gentilmente postos à minha disposição para uma análise preliminar que pode ser encontrada em Fábio W. Reis, Political Development and Social Class, tese aproximação interessante pode também realizar-se entre o problema da mobilização dos setores populares ou da classe trabalhadora em países como Brasil e Argentina (e talvez Espanha e Grécia, por exemplo), de um lado, e, de outro, os problemas da formação de identidades coletivas e de ativação política de categorias tais como negros, trabalhadores estrangeiros, mulheres, jovens e outras nos países desenvolvidos da Europa ocidental e nos Estados Unidos. Tratando-se de problemas que surgem em sociedades dotadas de estruturas políticas institucionalizadas e estáveis, estes últimos propiciam interessante corroboração da ideia de que a política ideológica envolve a tendência inerente à expansão do âmbito de interesses cuja realização é buscada através da operação do aparato institucional da sociedade. Ou, se posso recorrer ao vocabulário introduzido no início, eles corroboram a proposição de que, em qualquer momento determinado do desdobramento da política ideológica, o aparato institucional tenderá a mostrar-se como poder institucionalizado antes que como autoridade institucionalizada aos olhos de pelo menos algumas categorias de atores que procuram admissão plena ao mercado político.

de doutorado não publicada, Harvard University, 1974, caps. VI e VII). Pode-se ver, por exemplo, que as pessoas de "classe baixa" do estudo de Kirkpatrick revelam uma sensibilidade para com a importância do governo nacional para sua vida cotidiana que é muito maior do que a de categorias comparáveis Da amostra brasileira, e só encontra contrapartida entre os brasileiros que se enquadram nas categorias educacionais mais altas (curso secundário completo ou acima). 


\section{As forças armadas e a política}

René Armand Dreifuss ${ }^{1}$ Otávio Soares Dulci ${ }^{2}$

Durante certo tempo, sobretudo na primeira metade dos anos 70 , observadores e analistas políticos se concentraram no exame da instituição militar e do papel político por ela desempenhado no regime instaurado em 1964. A centralidade dos militares tornava-os objeto prioritário de atenção, muito embora a literatura sociológica e política não oferecessem aos interessados materiais abundantes sobre o tema. A própria carência de estudos, por sinal, estimulava o interesse. Prova disso foi dada pela repercussão de trabalhos como a análise sistêmica de Alfred Stepan, o estudo organizacional de Edmundo Campos e a exposição estrutural de Eliezer Rizzo ${ }^{3}$.

Ao longo da década, à medida que evoluía a estratégia de distensão adotada pelo governo Geisel, novos temas sobressaíram nas ciências sociais brasileiras. Assim, a relação Estado/Sociedade Civil, a questão da democracia, os movimentos sociais, o novo sindicalismo

1 Departamento de Ciência Política da Universidade Federal de Minas Gerais.

2 Departamento de Sociologia da Universidade Federal de Minas Gerais. 3 Alfred C. Stepan, The Military in Politics: Changing Pattem in Brasil, Princeton, 1971; Edmundo Campos Coelho, Em busca da Identidade: o Exército e a Política na Sociedade Brasileira, Rio de Janeiro, 1976, Eliezer Rizzo de Oliveira, As Forças Armada: Política e Ideologia no Brasil (19641969), Petrópolis, 1976. e os partidos políticos ganharam relevo como objetos de estudo. Maior atenção passou a ser dada a outros atores políticos, como os trabalhadores urbanos e rurais, os empresários, os tecnoburocratas e a Igreja, ao passo que diminuía a visibilidade dos militares. Agora, em seguida à realização das eleições de novembro de 1982, amplia-se a interrogação acerca da postura das Forças Armadas, diante do processo político, assim como sobre certos aspectos da instituição militar que podem ser fatores importantes para a análise da evolução política e para Q planejamento da ação política. A relevância dessas questões é sublinhada pelo quadro de instabilidade do continente, em função conflitos fronteiriços (Guatemala-Belize, Chile-Argentina, Chile-Bolívia, Chile-Peru, Equador-Peru, Venezuela-Guiana, Venezuela-Colômbia e o recente confronto entre a Argentina e a GrãBretanha em torno das Ilhas Malvinas), ao lado da crescente tensão política em países como a Colômbia e a Venezuela, do virtual estado de guerra civil/social em El Salvador, Quatemala e Honduras e da exaustão Política e administrativa de regimes militares como os do Uruguai e da Argentina.

Contudo, a renovação do interesse pelo estudo dos militares deve levar em conta mudanças profundas no perfil institucional, organizacional e ideológico das Forças Armadas brasileiras. Estas têm sido redefinidas em grande medida nos últimos dezoito anos e notadamente, em termos políticos e de Capacidade militar, desde meados dos anos 70. Nessa medida, presente trabalho busca contribuir para restaurar a instituição militar como tema de análise, 
focalizando seu papel político. E o faz segundo uma perspectiva diversa da que se adotava há dez anos, de modo a incorporar as mudanças estruturais que tiveram lugar durante o período.

Pretende-se a mi discutir a expansão de papéis das Forças Armadas, bem como a recepção (incompleta) de funções antes desempenhadas por civis, examinando-se alguns dos seus efeitos sobre o estabelecimento militar e o sistema político. O artigo também procura indicar modificações correntes de orientação, desdobramentos políticos e tendências possíveis, desde que papéis altamente complexos e pluralísticos devem se articular com funções polarizantes e autoritárias.

As transformações no sistema militar têm sido influenciadas por uma interpretação particular do que se considera como "estado relativo de segurança nacional", encaixam-se num corpo normativo e doutrinário abrangente e são condicionadas por um entendimento específico, por parte do núcleo do oficialato, do que seja desenvolvimento, sob que condições e através de que meios deve ser atingido. Além disso, tais mudanças têm sido reforçadas por percepções cambiantes a respeito dos obstáculos que se interpõem às intenções explícitas e aos objetivos implícitos das Forças Armadas na qualidade de intérpretes da vontade nacional e de como esses obstáculos afetam a segurança nacional, o desenvolvimento sócioeconômico, a modernização militar, a projeção nacional, a qualidade da liderança política e considerações geoestratégicas, interna e externamente. Essas transformações são moldadas por (e expressam) processos específicos dentro das Forças Armadas, de tipo organizacional, político e ideológico. Relacionam-se também com a natureza da oposição encontrada concretamente em diferentes segmentos da sociedade, com o caráter das alianças e alinhamentos estabelecidos através dos anos com setores civis privilegiados, com o potencial da nação e com o efetivo crescimento e a projeção do Brasil.

Sugerimos um esquema de análise que visa a situar e a caracterizar as referidas mudanças em três fases: antes de 1964, de 1964 até o início da abertura e, finalmente, o período atual. O pano de fundo, que interliga os diferentes momentos, as dimensões da instituição militar e sua interação com outros segmentos sociais, é dado pelo processo mais geral de modernização das Forças Armadas, sua diferenciação funcional e sua burocratização política, acompanhando e reagindo à crescente complexidade sócio-política do país.

O argumento principal do artigo é o de que, após 1964, as Forças Armadas se tornaram um ator político reformulado, desdobrando-se (tensionando-se) para desempenhar uma multiplicidade de papéis políticos e ao mesmo tempo pressionado por um conjunto de reivindicações e interesses freqüentemente contraditórios. Essas situações denominam de síndrome de tensãopressão. Caracteriza-se, por um lado, pela necessidade disfuncional de se esforçar consideravelmente e se desdobrar para atender a várias tarefas político-administrativas, satisfazendo simultaneamente 
diferentes setores da elite, mas revelando-se incapaz de contornar as reações dos grupos insatisfeitos e principalmente de atender a carências dramáticas dos atores populares. Por outro lado, pelo imperativo de lidar com diferentes pressões, vindas de dentro da própria instituição, interligadas aos focos potenciais de divergência — e de crise - no sistema. A síndrome de tensão-pressão se acumulava especialmente nos altos escalões da hierarquia, responsáveis pelos rumos da instituição. Manifestava-se nas Forças Armadas tanto quanto nas estruturas em que atuava - o governo, a comunidade de informações — e também no seu ponto de junção (por exemplo, Forças Armadas/governo) por efeito de interação.

Cabe aqui um esclarecimento importante. Embora, em virtude do escopo do trabalho, o tratamento que damos às Forças Armadas possa sugerir uma dimensão unívoca, homogênea, uma abordagem mais profunda do tema deve certamente contemplar as diferenças entre as três Armas (históricas, organizacionais, de base de recrutamento," de expressão e peso político, de áreas de atuação e outras) assim como as diferenças e os dissensos político-ideológicos, horizontais e verticais, em cada uma delas.

\section{As Forças Armadas antes de 1964}

Comecemos pela ideia de que ocorreu uma transformação paulatina no papel político das Forças Armadas anteriormente a 1964. Trata-se de assunto de certo modo coberto pelos estudos do período. Interessa-nos aqui ressaltar duas dimensões: a reformulação político-ideológica e a reformulação institucional/organizacional das Forças Armadas.

Em termos da reformulação ideológica e do papel político dos militares, ocorreu, em primeiro lugar, uma legitimação de seu intervencionismo no sistema político. Essa legitimação se fundamentava na doutrina de Segurança Nacional elaborada na Escola Superior de Guerra, mas cujas origens remontam ao Estado Novo. Por outro lado, o intervencionismo militar foi alimentado pela ação das correntes contrárias ao regime populista, notadamente a União Democrática Nacional — UDN, que tendiam a recorrer à intervenção militar como forma de corrigir o que consideravam como desvios do meio político e dos resultados eleitorais ${ }^{4}$. Reconhecia-se nas Forças Armadas o famoso "poder moderador", estudado por Fernando Pedreira, ${ }^{5}$ de resto implicitamente sancionado no texto constitucional, como assinala Stepan, ao determinar sua subordinação

4 Um tema importante da crítica ao regime populista referia-se à atenção que ele dava à classe operária em detrimento das classes médias. Essa crítica partia da visão de uma hierarquia social "natural", na qual as camadas médias ocupariam lugar intermediário, estabilizador. Tal noção, fortemente enraizada na UDN, foi assimilada na área militar como um contrapeso conservador ao que se percebia como subversão da ordem social por parte dos dirigentes do regime. Sobre a UDN e seu ethos, ver Otavio S. Dulci, "A União Democrática Nacional e o AntiPopulismo no Brasil", Dissertação de Mestrado, Universidade Federal de Minas Gerais, 1977; e Maria Victoria M. Benevides, A UDN e o Lidenismo, Rio de Janeiro, 1981.

5 Fernando Pedreira, Março 31: Civis e Militares no Processo da Crise Brasileira, Rio de Janeiro, capo 11, 1964. 
à chefia do Estado "dentro dos limites da lei". ${ }^{6}$ Essa cláusula restritiva, de aparência inócua, era suscetível de ser utilizada para questionar a "legalidade" dos governos constituídos, o que efetivamente aconteceu. $\mathrm{O}$ intervencionismo militar, em princípio fora de questão, seria legítimo quando a autoridade maior transpusesse, a juízo da instituição militar, os limites da legalidade.

Em segundo lugar, fixou-se a necessidade do desenvolvimento programático, a partir da mesma doutrina. A ênfase na programação do desenvolvimento correspondia a uma visão globalizante da sociedade e dos seus problemas. Essa visão orientava o esforço por adotar o planejamento estratégico, próprio da instituição militar, como padrão da atividade do Estado.

Elemento importante dessa visão globalizante era seu tom fortemente antipolítico, antagônico de fato ao que caracteriza a política: a existência de interesses particulares em conflito a serem conciliados no âmbito do Estado. Nesse particular, a perspectiva que prevalecia no meio militar era organicista; ${ }^{7}$ o que se pretendia era dar unidade orgânica ao sistema, superando-se os diversos antagonismos tidos como fatores de divisão e, em última análise, de desagregação. A existência de partidos, por exemplo, era encarada com reservas, pelo seu caráter de "partes" em oposição mútua, perturbando a unidade social. Além disso, a percepção da Ineficácia e da

6 Alfred C. Stepan, op. dt, p. 75.

7 Mike Burgess e Daniel Wolf, "Brasil: o Conceito de Poder na Escola Superior de Guerra", Revista de Cultura Vozes, LXXIV (5), 1980. inadequação do sistema partidário, um como das personalidades que nele atuavam, levava a questionar sua validade em face dos objetivos nacionais.

Sobre tais pressupostos, insistia-se na meta do fortalecimento do Estado, ligada ao problema da ordem. O reforço da autoridade pública, a centralização política e administrativa, a capacidade do Estado de controlar a vida social eram objetivos salientados pelos militares, sobretudo em face da mobilização sócio-política que cresceu desde o fim dos anos 50. As reservas em relação à política tinham como contrapartida a ênfase no econômico, por sua importância crucial para o desenvolvimento e portanto para a segurança nacional. O lema "Ordem e Progresso", caro aos positivistas que ajudaram a fundar a República, atualizavam-se na ideia de Segurança e Desenvolvimento. Ao Estado fortalecido caberia levá-la à prática.

A partir da constatação do divisionismo ideológico, inclusive no interior da corporação, procurava-se incrementar a homogeneidade ideológica entre setores sociais estratégicos. A sociedade civil, em sua pluralidade, continha aliados potenciais a serem articulados ao projeto em esboço na área militar. Desenvolvese daí a percepção da legitimidade e da necessidade — da interação orgânica de militares e empresários, que conferiu a marca política da Escola Superior de Guerra.

Em suma, a função política desempenhada pelas Forças Armadas antes de 1964 foi a de restauração da ordem vigente em 
momentos de crise. Em outras palavras, os militares representaram um fator de poder de tipo bonapartista, legitimado constitucionalmente.

Quanto à reformulação institucional, uma discussão que ganhou corpo no decorrer do período referia-se aos entraves à eficiência da corpo ração militar enquanto organização profissional. Vários aspectos devem ser aí ressaltados, todos eles fontes de crescente preocupação dentro das três Armas.

Um deles era o grau insuficiente de autonomia da instituição, que a sujeitava à "política civil". Isso se manifestava particularmente no tocante à manipulação das promoções dos oficiais mais graduados por parte de autoridades civis. ${ }^{8}$ Oficiais eram prestigiados ou punidos de acordo com critérios político-ideológicos, à revelia da instituição. O clímax do problema emergiu, certamente, com o governo Goulart, mas a polêmica já era acentuada durante a administração Lott no Exército.

Paralelamente, discutiam-se as regras concernentes à carreira militar. A questão dos limites de idade para a permanência em postos ao longo da hierarquia, a questão do recrutamento de militares para cargos civis enquanto ainda na ativa eram temas mal definidos na

8 Sobre isso, ver Maria Victoria M. Benevides, O Governo Kubitschek.'Desenvolvimento Econômico e Estabilidade Política, Rio de Janeiro, capo IV, 1976; Alexandre de S. C. Barros, "The Brazilian Military: Professional Socialization, Political Perfonnance and State Building", Dissertação de Doutorado, Universidade de Chicago, 1978, p. 209; é René A. Dreifuss, 1964: A Conquista do Estado, Petrópolis, cap. IV, 1981. legislação, que concorriam para diminuir a autonomia da instituição, prestando-se a interpretações particularistas, "políticas".

Preocupação de outra ordem surgia com a percepção de clivagens de tipo "classista" dentro da instituição. A articulação de grupos específicos — os coronéis, os sargentos - era tida como altamente negativa por ser fator de divisão interna, quebrando a estrutura hierárquica e, sobretudo, por engolfar a instituição militar nos conflitos sociais. As Forças Armadas seriam assim emparelhadas às demais instituição. A articulação do movimento dos sargentos, desde 1961, foi especialmente preocupante, porque tida como ameaça à segurança nacional.

De grande importância era a questão da capacidade instalada. Tema de discussão ampla era o fato de estarem as Forças Armadas subequipadas para desempenhar suas atividades. Esse debate englobava diversos tópicos percebidos pelos militares como relevantes:

1. A impossibilidade de atingir objetivos legítimos por carência de recursos; um objetivo fundamental como a ocupação do espaço nacional era prejudicado pela baixa capacidade instalada;

2. O material bélico e a dependência de suprimentos estrangeiros:

3. Os efetivos;

4. O nível de especialização e aperfeiçoamento do sistema de educação militar;

5. Os recursos alocados pelo Estado;

6. A perspectiva de erigir um complexo industrial-bélico e de estabelecer um complexo empresarial-militar. 
Os elementos acima apontados, de reformulação políticoideológica e de 'reformulação institucional, confluem para modelar a percepção e a atitude das Forças Armadas após 1964. Eles vão determinar a nova postura, seja para evitar, contornar ou suprimir problemas, seja para reforçar algumas características.

\section{Forças Armadas após 1964}

Examinando agora o processo subseqüente ao movimento de 1964, podemos desdobrá-lo em etapas que marcaram os rumos da modernização das Forças Armadas e de sua ação no plano político.

Uma primeira etapa iria de 1964 ao Ato Institucional nº 5, de dezembro de 1968. Nela se observava um enfrentamento de tendências dentro da "área revolucionária". O foco principal de divergência era representado pelo caráter atribuído à "revolução". Seria ela uma intervenção transitória, cirúrgica, por assim dizer, do tipo "devolver e limitar" mencionado por Huntington, ${ }^{9}$ para uns restauradora da ordem constitucional, para outros reformadora dessa ordem, mas destinada a refluir como processo? Ou essa intervenção seria o início de um processo revolucionário permanente, que não deveria ser enquadrado nos limites da legalidade convencional? O Ato Institucional $\mathrm{n}^{\circ}$, ao cabo do período, assinalou a vitória da

9 Huntington propõe urna tipologia de atitudes que um Exército pode tornar após intervir em um golpe de veto, "em termos de se conservará o poder ou o devolverá aos civis, e de se aceitará ou resistirá à expansão da participação política". A opção "devolver e limitar", ilustrada pela experiência argentina de Ararnburu. segunda opção.

O bonapartismo constitucional das Forças Armadas brasileiras chegara ao fim com os eventos de abril de 1964. Com o AI-5, as Forças Armadas se tornaram o Poder Dirigente sobre a nação. Elas assumiram a promoção do Desenvolvimento pela garantia da Segurança, na forma definida pelos ideólogos da Escola Superior de Guerra e dentro das condições da lógica da coerção. Sua política voltava-se para a permanência do "poder revolucionário" de modo a fazer do país, por volta do fim do século, uma potência reconhecida mundialmente. Esse projeto nacional demandava "estabilidade política"; a democracia seria o produto final de uma evolução controlada de cima. Um conceito autoritário de poder foi então adotado como fundamento, como técnica e forma organizacional do regime, cristalizando-se no Ato Institucional no5.

A passagem do papel bonapartista constitucional para o de Poder Dirigente representava menos uma mudança na natureza do que no âmbito de atribuições e na forma de implementação. Em ambos os casos as Forças Armadas constituíam um aparato do Estado, cujos valores circunscreviam-se ao universo das classes dominantes e cujas normas eram as de um bloco histórico capitalista. Contudo, no novo sistema a qualificação "dentro dos limites da lei", característica do período pré-1964 e que foi mantida na Constituição de $1967,{ }^{10}$ atribuía às Forças Armadas a faculdade efetiva de definir

10 "As forças armadas, constituídas pela Marinha de Guerra, Exército e 
limites e transgressões ou, mais exatamente, situava esta atribuição dentro dos parâmetros bastante amplos do AI-5, cuja implementação ficava a cargo dos dois centros de ação mais importantes após a queda de Perón em 1955, consiste na devolução do poder aos civis depois de um breve período de governo e de um expurgo no serviço público, ao passo que os militares continuam limitando a ascensão de novos grupos ao poder político. $\mathrm{O}$ autor adverte, porém, que "quase sempre reaparece a necessidade de intervir". Samuel P. Huntington, El Orden Político en las Sociedades en Cambio, Buenos Aires, 1972, pp. 210-211 das Forças Armadas, o sistema ou "comunidade" nacional de informações, englobando os vários serviços e agências de informações das forças singulares, e o Conselho de Segurança Nacional. Tal mudança elevou o nível de politização (em outras palavras, reduziu o nível de profissionalização e autonomia) e fez gradualmente com que os padrões de carreira e o acesso à hierarquia se tomassem um empreendimento altamente ideológico, afetando agudamente a estrutura profissional. As promoções tornaram-se intensamente políticas.

A passagem para Poder Dirigente tornou problemática a relação das Forças Armadas com a sociedade, particularmente com as elites dirigentes. As Forças Armadas, como força bonapartista

Aeronáutica Militar, são instituições nacionais, permanentes e regulares, organizadas com base na hierarquia e na disciplina, sob a autoridade suprema do Presidente da República e dentro dos limites da lei." Constituição do Brasil, art. 92, 1967. O dispositivo foi mantido pela Emenda Constitucional n? 1, de 17 de outubro de 1969, que é a Carta em vigor. constitucional, eram legitimadas pelas "elites", em nome da sociedade, para agir na defesa de uma ordem consensual particular. Dentro dessa convenção, diferentes setores, segmentos e grupos preconizavam modelos econômicos e políticos variados, mas nos marcos de um paradigma social que era compartilhado no fundamental. Como Poder Dirigente, ao invés, as Forças Armadas se assemelhavam perigosamente a uma guarda pretoriana, face ao social, manobrando para promover os interesses dominantes enquanto estes se constituíam em interlocutores privilegiados assegurando-lhes condições para a sua supremacia através da estratégia de desenvolvimento e segurança política adotada. Neste sentido, reforçavam-se o convívio e o consenso dos militares com setores privilegiados tanto pela sua inserção econômica quanto pelo próprio convívio de poder que os tornava parceiros seletivos das Forças Armadas. Paradoxal mas compreensivelmente, neste processo de interação excludente com setores empresariais da indústria e das finanças mais as burocracias civis (técnicos e administradores) houve um incremento do grau de autonomia institucional, fechando-se a corporação a pressões externas de grupos estabelecidos na sociedade ou de camadas distinguíveis e favorecendo-se o cupulismo político no interior da instituição. Consolidaram-se as ambições e desígnios próprios das Forças Armadas, enquanto a cúpula manobrava em nome da instituição. Por outro lado, requeria-se também das Forças Armadas, enquanto Poder Dirigente, que impedissem a transferência dos centros nacionais de decisão para o interior das estruturas 
transnacionais de poder, embora a industrialização do país tivesse como carro-chefe as empresas multinacionais e associadas. Esse requisito implicava uma dissonância de papéis e funções e, por extensão, um rearranjo das relações externas, de Estado a Estado ${ }^{11}$.

As Forças Armadas se propunham, nesse contexto, a fortalecer o Estado, a neutralizar as tensões sociais, a suprimir o dissenso político e a alcançar um elevado crescimento econômico. Esses múltiplos objetivos envolviam um processo de expansão de papéis, quer dizer, o preenchimento de uma série de atividades padronizadas a partir de uma definição de tarefas a cumprir; envolviam também uma metodologia de ação, um roteiro que, embora não equiparasse propriamente as necessidades do Estado e os interesses da empresa privada, conduziu as Forças Armadas a uma situação em que a estratégia política foi subordinada a política de crescimento economicamente definidas, ou seja, em que interesses econômicos privados foram identificados com o Poder Econômico da nação, alcançando com isso influência considerável sobre os assuntos nacionais. $^{12}$

11 Uma série de eventos marcou esse realinhamento: o acordo KissingerSilveira, a denúncia do Acordo Militar Brasil-Estados Unidos, a nova política para a África, A política atlântica, a posição política militar em face do Caribe e da América Central, a questão da energia nuclear, o ponto Amazônico, a decretação do mar territorial de 200 milhas, a projeção sulamericana do país.

12 Segundo a elaboração doutrinária da Escola Superior de Guerra, os fatores do Poder Econômico são: população economicamente ativa, qualificação da mão-de-obra, ciência e tecnologia, capacidade empresarial,
A hierarquia e o planejamento proporcionariam assim canais aceitos e legítimos de acesso aos interesses estruturados. $\mathrm{Na}$ linha desse argumento, o Executivo seria, em estilo e em critérios de tomada de decisão, marcadamente militar, embora não necessariamente em uniforme e certamente não militar no tocante à formulação de políticas.

Da perspectiva da congruência de valores e da relação entre o empresariado e as Forças Armadas, o binômio Segurança e Desenvolvimento só poderiam ser a segurança e o desenvolvimento dos componentes da relação, para que esta se mantivesse. Quase por definição, universos antagônicos só poderiam surgir entre os setores sociais subordinados, irracional mente ou por ação manipulada, em oposição às intenções das elites de promover ordenadamente o progresso. Qualquer tentativa das massas de pôr cobra à sua condição e de melhorar sua posição na correlação de poder seria então percebida e caracterizada como subversão da ordem vigente. De tal situação só poderia derivar um processo de "crise permanente", a ser enfrentado somente por um poder revolucionário permanente.

aproveitamento de recursos naturais, características geo-econômicas, modelo econômico, possibilidade de investimento. As funções do Poder Econômico são definidas como sendo; administrativa, normativa, produtiva, distributiva (circulatória e repartitiva), Seus órgãos são organizações públicas (ministérios, conselhos, empresa pública) e organizações privadas (empresa privada, associações de classe). Os poderes que o compõem são o poder geoeconômico, o poder financeiro, o poder tecnológico, o poder agrícola, o poder de comércio e I:) poder industrial. Escola Superior de Guerra, Manual Básico 75, pp.143-162. 
O regime militar prolongado serviria para suprimir o descontentamento é o dissenso na sociedade civil, por meio da repressão de organizações autônomas e de ações políticas e ideológicas dos setores populares. Não obstante, estas renasceram sob outras formas, como movimentos não institucionalizados, associações de bairros, comunidades de base, insatisfação e apatia populares generalizadas, alimentando até mesmo o descontentamento dentro das próprias Forças Armadas. A erosão da sociedade civil "legítima" através dos métodos do regime militar não se pode dissociar da reconstituição contínua de uma sociedade civil autônoma, transcendendo os limites da dominação de classe.

$\mathrm{Na}$ fase seguinte, que vai até o início do governo Geisel, consolida-se e reproduz-se o processo revolucionário permanente. Essa consolidação se liga ao controle da sociedade e da política pelas Forças Armadas (junto com seus aliados preferenciais no meio civil) e ã supressão de dissensos militares pelo AI-5.

A terceira etapa, de 1974 à revogação do AI-5 (dezembro de 1978), abrange a reversão do processo revolucionário, enquanto expediente ou radicalismo inconseqüente, pelo desmantelamento de alguns de seus componentes e pelo reajustamento de outros. O resultado dessa reversão é o processo de abertura política, designado em seus primórdios por distensão ou descompressão, cujo impacto sobre as Forças Armadas será discutido na parte final deste trabalho.

Tendo em mente essa periodização, que chama a atenção para o caráter dinâmico, variável, da posição das Forças Armadas no sistema político, vejamos os aspectos referentes às transformações ocorridas em seu comportamento político-ideológico e em sua estrutura institucional.

No plano político-ideológico, os quinze anos subseqüentes a 1964 constituíram um período de capacitação e incremento do potencial da instituição militar para tomar-se ator político relevante, isto é, força política autônoma capaz de impor seus interesses e necessidades institucionais aos demais atores políticos. Face à percepção crítica dos problemas existentes no sistema anterior, a instituição militar desenvolve ação efetiva no sentido de reformularse e de reformular o sistema. Conta para isso com a posição de força obtida por seu papel no golpe civil-militar de 1964, que lhe conferiria em breve a direção do Estado.

Novos recursos são desenvolvidos e novos papéis são assumidos. Uma distinção fundamental tem a ver com o fato de que antes de 1964 os militares ocupavam posições civis ${ }^{13}$ em parte por

13 De acordo com Johnson, havia aproximadamente 1000 oficiais em cargos civis por volta de 1960. John J. Johnson, Military and Society in Latin America, Stanford, 1964, p. 211. Benevides apresenta uma relação de militares que ocupavam posições civis, quais postos ocupavam e as áreas em que as Forças Armadas se envolveram pela presença de seus membros em cargos administrativos. Maria Victoria M. Benevides, O Governo Kubitschek, op. cit., pp.147-148 e 187-188. Ainda vale a pena salientar que no início dos anos 60 havia aproximadamente 7000 oficiais na atividade privada e que na década de 80 ao redor de 15000 oficiais ocupam cargos na administração pública direta e indireta. (Cf. estimativa de Walder de Goes, na sua exposição no $\mathrm{V}$ encontro da ANPPCS, Nova Friburgo, outubro/1981). 
concessão dos políticos civis (ou em virtude de um acordo entre eles). Após 1967, a situação se inverte: civis ocupam posições por concessão militar, com a notável exceção dos postos diretamente relacionados com a política econômica, embora mesmo estes fossem sujeitos à vigilância do sistema militar de informações. "A análise, portanto, não se deve limitar ao número de militares comparado com o de civis, mas às novas áreas em que eles se envolveram" ${ }^{\prime 14}$.

Funções antes preenchidas por civis foram acumuladas pelos militares, segundo um modelo de "recepção incompleta de papéis e funções". Assumidos circunstancialmente esses papéis e funções, sua atribuição a militares era rotinizada pela própria experiência adquirida por eles ao desempenhá-los; ela assim se institucionaliza e se toma manifestação estrutural do sistema. Tal recepção 4e papéis e funções certamente derivava da vontade dos militares, mas advinha sobretudo de necessidades que eles percebiam, face às suas críticas ao sistema anterior e à forma de ação e de comportamento dos políticos civis.

A expansão de papéis da instituição militar ligava-se a certas condições da época. Uma foi a ruptura da frente empresarial formada para lançar o movimento de abril, frente que teve no complexo IPES/IBAD seu verdadeiro estado-maior ${ }^{15}$. Outra, a ruptura sócio-

14 Alexandre de S. C. Barros, op. cit., p. 209.

15 Sobre o IPES (Instituto de Pesquisas e Estudos Sociais), o IBAD (Instituto Brasileiro de Ação Democrática) e sua atuação, ver René A. Dreifuss, op. cit., caps. V a X. política representada pelo "saneamento" da área política, pela marginalização dos líderes de porte nacional e pela fragmentação da estrutura partidária, resultando num vácuo político e administrativo preenchido por tecno-empresários e militares. Os políticos tomaramse ancilares. As reformas introduzidas nos canais de elaboração de políticas e de tomada de decisões - preparadas sobretudo no governo Castello Branco e para as quais o IPES proporcionou o referencial básico - excluíam dos centros de poder os políticos tradicionais e, no mesmo passo, favoreciam a participação dos militares.

Sob tais condições, as Forças Armadas tornaram-se mais articuladas, diferenciadas e independentes da sociedade civil, reforçadas por sua socialização profissional específica e seus padrões de recrutamento, aos quais se acrescentavam fatores como um fluxo de realimentação ideológica dentro da instituição e laços familiares intermaritais.

Em termos concretos, a expansão de metas e o envolvimento das Forças Armadas resultou na atribuição a elas de quatro papéischave:

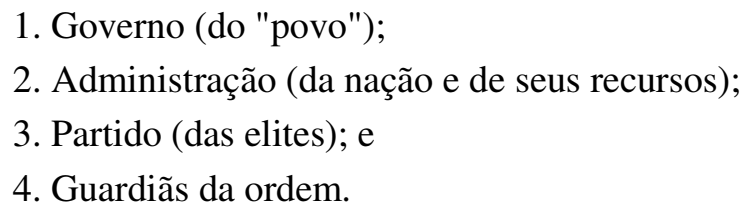

2. Administração (da nação e de seus recursos);

3. Partido (das elites); e

4. Guardiãs da ordem.

Como instância do Estado, a instituição militar se apresentava também em sua dimensão burocrática — ou seja, como parte do 
serviço público - e como organização de inteligência política. Ramificava-se, por outro lado, num complexo industrial-militar, ao passo que o papel de partido das elites se realizava no contexto da formação de um complexo empresarial-militar, através do qual figuras de destaque do meio militar eram incorporadas à atividade empresarial.

As funções anteriores se mantinham, sendo reformuladas e reforçadas: a função coercitiva, de "polícia da política", e a função ideológica, de doutrinação das elites, cujo alcance se procurou estender a outros setores sociais.

O exame minucioso desse novo quadro iria além dos objetivos do presente trabalho. Procuraremos, porém, destacar alguns de seus aspectos: a presença das Forças Armadas no governo e na administração, a dimensão organizacional após 1964, a formação do complexo industrial-militar e a questão da área de segurança e informações.

Uma vez no poder, as Forças Armadas se encontraram diante de um acúmulo de problemas econômicos, sociais e políticos. É certo que as grandes questões de ordem econômica foram enfrentadas por civis, oriundos dos grupos de estudo e doutrina do IPES ou diretamente articulados a este. Só mais tarde verificou-se o envolvimento de oficiais em assuntos tidos como civis, e mesmo assim de maneira seletiva.

De toda maneira, esperava-se a intervenção das Forças Armadas em problemas importantes, no plano social e político, que afetavam de várias formas vastos segmentos da população. Tratar-seia de promover o que se designava por "redistribuição indireta" de benefícios sociais. Dessa forma, implementaram-se políticas destinadas à "melhoria das condições de grupos sociais, mantendo-se porém a existência de divisões (não necessariamente as existentes)". ${ }^{16}$

A institucionalização de uma "mentalidade de crescimento", como estratégia aberta de legitimação, iria objetivamente antepor os Objetivos Nacionais Permanentes e Atuais definidos pelos militares às necessidades populares, alienando a participação popular no projeto de desenvolvimento, na medida em que o "Poder Econômico" da nação, tal como era definido pelo regime, cingia-se ao setor público juntamente com a empresa privada. Foi precisamente em torno dessa definição que surgiram divergências dentro das Forças Armadas no final dos anos 60 e no início dos 70, o que veio a afetar a intenção dos comandos de obter "o máximo de desenvolvimento possível com o mínimo de segurança indispensável".

As Forças Armadas moviam-se dentro de um paradigma político ideológico que as levava a conceber o subdesenvolvimento como produto não apenas ou essencialmente da exploração capitalista, mas de insuficiente desenvolvimento capitalista. O desenvolvimento a ser alcançado devia ser "associado", devido a carências tecnológicas do país, à sua escassez de capital e às

16 Alexandre de S. C. Barros, "The Changing Role of the State in Brasil: the Technocratic-Military Alliance", 1976, mimeo., p.5. 
deficiências gerenciais existentes. Devia ser também subalterno, em termos hemisféricos, por razões geopolíticas. A partir dessa ideologia, as Forças Armadas, com certa relutância, abriram mão de sua iniciativa em favor do complexo multinacional e associado. Em conseqüência, tiveram de pagar o preço de estarem no palco sem propriamente representarem o seu ato.

Como governo, as Forças Armadas se incumbiram de determinar, executar e controlar as políticas. Contudo, não interferiram na formulação dessas políticas, tarefa a cargo de civis, a não ser em áreas que tivessem implicações militares. "A despeito do papel crescente do Estado, as forças de mercado em sentido amplo determinam a alocação e a direção do desenvolvimento. As empresas estatais simplesmente respondem aos sinais do mercado" ${ }^{\text {,17. }}$.

A formulação de políticas resultava de um processo de seleção que abrangia a comunidade empresarial. Os grupos e setores relevantes estavam em condições de sugerir e articular suas opções por meio de diversos canais de comunicação, a exemplo dos próprios ministérios, das associações de classe, dos comandos militares etc ${ }^{18}$.

17 Werner Baer et al, "On State Capitalism in Brasil: Some New Issues and Questions", 1976, mimeo.

18 O conceito de "anéis de poder", cunhado por Cardoso, exprime bem essa realidade. Cf. Fernando Henrique Cardoso, Autoritarismo $e$ Democratização, Rio de Janeiro, caps. V e VI, 1975. A situação levou Luiz Eulálio de Bueno Vidigal, presidente da Federação das Indústrias de São Paulo, a jactar-se de que os canais de comunicação diretos abertos pelos industriais entre a FIESP e o governo desembocam diretamente no ministro do Planejamento, no ministro-chefe do Gabinete Civil, no ministro da
No governo e como administradores, as Forças Armadas assumiram a promoção da economia, não como arquitetas do seu projeto, mas como planejadoras incompletas e em termos de execução. Tomaram a si o núcleo superior da atividade do Estado, mas não necessariamente o núcleo central ou mesmo as pastas governamentais cruciais. Vale assinalar que uma área do Ministério que se poderia supor estar completamente ocupada por militares, em vista de suas premissas metodológicas e seu discurso, seria o setor de planejamento. No entanto, o Ministério do Planejamento tem sido ocupado até hoje por tecno-empresários de alto nível, mantendo-se como área estritamente civil.

O planejamento estatal tem servido prioritariamente ao propósito de mobilizar poupança e canalizá-la para pontos potenciais de estrangulamento, financeiros e industriais, ao mesmo tempo que se incrementa a montagem de uma política macroeconômica, em função dos interesses empresariais domésticos e multinacionais; estes necessitam do planejamento público para garantir a vitalidade do

Aeronáutica, no ministro da Indústria e Comércio, no vice-presidente da República, no secretário particular do Presidente, no ministro dos Transportes, no ministro-chefe do SNI, no chefe do Gabinete Militar, no ministro da Fazenda, nos secretários-gerais dos Ministérios da Fazenda, do Planejamento e do Conselho de Desenvolvimento Industrial, no presidente do Banco Central e no diretor da CACEX (Carteira de Comércio Exterior) do Banco do Brasil. "Nós podemos fazer contacto em qualquer momento", disse Vidigal, "quando algum assunto assim o exige. Esse diálogo, permanente e direto, auxiliará o país. Poderemos participar das decisões e dar sugestões que consideramos fundamentais". Jornal do Brasil, 16.11.1980. 
setor privado. A presença de pessoal militar à testa do setor de planejamento, descomprometido com ou não cooptado por interesses civis privados, seria um risco que nem as indústrias de armamentos desejariam correr, face à possibilidade de que esses militares introduzissem novos critérios de racionalidade e procurassem repolitizar a doutrina de Segurança e Desenvolvimento, ou seja, problematizassem, tematizassem e questionassem sua sobre determinação. A outra opção, de cooptar- as personalidades militares encarregadas do planejamento, acarretaria um desgastante esforço de intromissão.

Com a primeira opção, o planejamento seria revelado naquilo que tem efetivamente sido: não somente planejamento incompleto, mas também a ausência de planejamento nacional, isto é, a falta de consideração das necessidades e direitos da população em geral. Seria cada vez mais estranho, para dizer o mínimo, para certos setores de opinião no interior das Forças Armadas, que o que se supunha ser um esforço geral (através do planejamento nacional) para desenvolver a nação pudesse ser reduzido ou prejudicado pelo comportamento particularístico tanto do pessoal técnico quanto de companhias privadas, locais e transnacionais. Se tratava de uma guerra contra a pobreza, o subdesenvolvimento, a miséria, a fome, a falta de teto e de educação, então deveriam ser empregados os instrumentos e as medidas de guerra - nacionalização, requisição de bens, direção nacional e centralizada da produção para cobrir necessidades etc. - em nome da segurança nacional e do desenvolvimento.

Isso teria significado privilegiar o campo e a ação psicossociais, que na doutrina da ESG é uma entre quatro variáveis (as outras três sendo a econômica, a política e a militar) transformando-a em determinação máxima, que a tudo envolvesse. A ação psicossocial seria assim detecnificada, o que desnudaria o caráter solipsístico do planejamento corrente, pelo qual a única realidade importante é a elite em um vasto contexto nacional, no qual os instrumentos de produção (tanto os trabalhadores quanto o equipamento) devem ser conservados em estado de relativa eficácia, assegurada por supervisores competentes e capazes de manter relações adequadas com os serviços públicos e os fornecedores. Aí que se observavam áreas de conflito entre o governo militar e a instituição militar.

Desdobramentos posteriores, pelos quais se verificaram pressões militares para participar da fiscalização do planejamento nacional, e dessa forma alcançar certa parcela de influência nas áreas de decisão econômica, parecem ter levado a resistências suficientes para engrossar a campanha contra a estatização, lançada por setores empresariais no final dos anos 70 .

As Forças Armadas não eram neófitas em face das complexidades da administração pública. Haviam tido participação importante na industrialização do país, seja treinando e preparando técnicos e administradores, seja como grupo de pressão para diferentes projetos e indústrias específicas, ou como legitimadoras de 
anéis tecno-empresariais envolvidos na tomada de decisões sobre prioridades industriais. ${ }^{19}$ Registrou-se também a presença de militares em importantes pastas ministeriais, na direção de autarquias e em postos elevados de um grande número de órgãos públicos ${ }^{20}$. A tendência para o aproveitamento de militares na administração pública foi nitidamente reforçada após 1964 e, por volta de 1979, $27,8 \%$ dos altos funcionários do Estado (administração direta, empresas estatais e sistema autárquico) eram militares ${ }^{21}$.

A presença direta de militares na gestão de empresas públicas, bem como sua estreita relação com um amplo espectro de interesses empresariais — tanto em termos de complexo empresarial-militar quanto no tocante à indústria bélica — afastava quaisquer suposições que porventura persistissem sobre o isolamento dos militares em face dos setores civis. Se esse quadro de relações existia já antes de 1964, foi sem dúvida reforçada após o golpe e acentuou-se desde o início da década de 70 .

Mesmo contribuindo para estimular clivagens e correntes de opinião, tal situação não veio dividir os militares segundo linhas que se poderia razoavelmente prever, do tipo nacionalista/associacionista,

19 Sobre esse ponto, ver René A. Dreifuss, op. cit., cap. III.

20 Entre esses órgãos, mencionem-se o Ministério da Viação e Obras Públicas, o Departamento de Correios e Telégrafos, a Comissão de Marinha Mercante, a Estrada de Ferro Leopoldina, a PETROBRÁS, o Conselho Nacional de Petróleo, a Companhia Siderúrgica Nacional, o Departamento de Aviação Civil, a Comissão Nacional de Energia Nuclear, o Conselho Nacional de Pesquisas.

21 Walder de Goes, O Estado de S. Paulo, 25.11.1979. estadista / privatista etc. Se divergências havia, elas se davam primordialmente em torno de subsistemas da instituição, do tipo segurança-informações versus profissionais.

$\mathrm{O}$ que parece ser um fato novo é o aparecimento de contradições entre os militares como administradores públicos e os que são recrutados para a direção de empresas privadas, muitas destas subsidiárias de grupos multinacionais. Outra tendência, incipiente mas não menos problemática, refere-se à expectativa de escalões inferiores e intermediários sobre a postura da corporação diante dos crescentes problemas econômicos, tendência essa que exprime uma visão cada vez mais crítica do próprio modelo. ${ }^{22}$ Nesse sentido, alternativas importantes são discutidas: desenvolvimento nacional ou crescimento multinacional, desenvolvimento industrial ou acumulação financeira, desenvolvimento socialmente orientado ou economicamente orientado etc .

As normas e valores da hierarquia militar revelaram-se bastante inadequadas para resolver divergências políticas e ideológicas da oficialidade. Assim, a par da expansão de papéis político-ideológicos, a instituição militar encaminhou-se no rumo de uma ampla reformulação organizacional. Tratava-se de superar os

22 Contudo, a crença em um ethos organizacional como princípio orientador da ação política contribui para evitar divisões profundas. Esse fator descarta o exercício do poder por facções de qualquer orientação ideológica. Somente a ação subsistência (informações, segurança) teve campo para se desenvolver, embora de forma impessoal, sob risco de romper a unidade da corporação. 
entraves, antes diagnosticados, à realização de seus objetivos. Desde logo medidas foram adotadas para garantir maior autonomia à instituição, por meio de legislação específica - o Estatuto dos Militares, introduzido no governo Castello Branco que regulamentava a carreira militar, as normas de promoção, as condições de exercício de funções civis, as manifestações públicas de oficiais, inclusive destinadas ao "público interno", e assim por diante.

Questão da maior importância, a das divisões políticas dentro da corporação, foi enfrentada por uma ação sistemática de despolitização, vale dizer, supressão do envolvimento de militares dos escalões intermediários em questões políticas ao lado de civis. Essa despolitização visava a impor como orientação homogênea aquela que correspondia às opções do grupo que controlava política e ideologicamente a instituição, vedado o debate em torno de suas posições. Instrumento estratégico dessa unificação era o projeto de criação do Ministério da Defesa, englobando as três Forças sob direção política única. A ideia, porém, não prosperou. Sua inviabilidade é indicativa da permanência de divisões internas, observáveis desde os conflitos que emergiram no período Castello Branco (promotor do projeto) até divergências recentes entre setores das três Armas.

Outra questão fundamental, encaminhada após 1964, era a maximização do potencial militar. As Forças Armadas foram modernizadas, tornando-se mais consistente esse processo pela implantação da indústria bélica. Ao mesmo tempo foram ativadas indústrias de interesse estratégico, como a nuclear. Estruturava-se assim o que temos designado por complexo industrial-militar. Essa orientação receberia grande impulso após a denúncia do Acordo Militar Brasil-Estados Unidos, medida adotada pelo governo Geisel em março de 1977, a partir da qual reverteu-se o absoluto comprometimento do Brasil com a indústria bélica norte-americana e consolidou-se uma política de independência nacional nesse terreno, a qual se concretizava numa faixa própria de atuação que limitava a dependência ao campo da tecnologia de ponta.

Em menos de dez anos, aponta Clóvis Brigagão, ${ }^{23}$ um sistema militar superado tornou-se um complexo industrial-militar situado entre os quinze maiores do mundo em termos de capacidade produtiva, de desenvolvimento tecnológico e de exportações. Existem aproximadamente 350 empresas - estatais, nacionais privadas e multinacionais - envolvidas direta ou indiretamente na produção de material bélico, empregando cerca de 150000 pessoas, formando um setor que movimenta em torno de 5 bilhões de dólares e cujo total de vendas, em 1980-81, atingiu 1,5 bilhões de dólares, segundo fontes que geralmente subestimam tais vendas. Em fins de 1981, uma publicação especializada assinalava que "o Brasil tem a indústria de armamentos maior e tecnicamente mais avançada do Terceiro Mundo. Está em permanente expansão e sem dúvida

23 Clóvis Brigagão, "A Corrida Armamentista Mundial", Jornal de Brasil, 23.5.1982. 
propõe-se a se converter no principal exportador de armas dentro de pouco tempo. Aproximadamente $40 \%$ do parque militar brasileiro são produzidos no país, em grande parte sob licença, mas com proporção sempre crescente de armas concebidas e desenhadas no país". ${ }^{24}$

Esse ambicioso empreendimento surgiu, em sua forma industrial moderna, dos Planos de Reaparelhamento das Forças Armadas, traçados nos anos 60 como resultado da associação das Forças Armadas com grupos industriais, esses através dos Grupos de Mobilização Industrial, ${ }^{25}$ empresas estatais e corporações multinacionais. Utilizando-se a capacidade ociosa de indústrias civis, durante o período Castello Branco, as Forças Armadas seriam supridas com material produzido nessas fábricas, ao passo que

24 Armies of the World, Londres, 1981, cit. pelo Jornal do Brasil, 12.11.1981.

25 O Grupo Permanente de Mobilização Industrial tem promovido uma política consistente de desenvolvimento técnico de forma que o setor privado, subsidiado sob a cobertura institucional da IMBEL, produza, mantenha, repare e exporte material bélico. O GPMI encara seu papel como uma missão: desenvolver a estratégia do país juntamente com as Forças Armadas. Uma missão em termos de Segurança Nacional. Clóvis Brigagão, "Military Research and Development in Brazil: an Evaluation", 1981, mimeo, pp. 23-24. Em conferência na Escola Superior de Guerra, quando o conflito das Malvinas punha na ordem do dia a questão da capacidade militar do país, o ministro do Planejamento, Delfim Neto, ressaltou a importância da mobilização industrial; "Um país só pode se sentir forte se ele dispuser de capacidade de se mobilizar industrialmente, em caso de necessidade. Não adiante importar armamentos e depois ficar na dependência externa de fornecimento de munição ou peças de reposição". Folha de S. Paulo, 3.6.1982. alternativas industriais, tecnológicas e financeiras foram criadas para erigir uma indústria bélica nacional, capaz de competir no mercado internacional na faixa de tecnologia intermediária.

Aos poucos o setor foi sendo implantado, com o apoio de universidades no Rio de Janeiro, São Paulo e Rio Grande do Sul, bem como de centros e institutos de pesquisas como o Centro Técnico Aeroespacial, o Instituto Militar de Engenharia (do Exército) e o Instituto de Pesquisas da Marinha. Acrescia a isso o suporte de agências financeiras do governo, o Banco do Brasil, o Banco Nacional de Desenvolvimento Econômico e bancos regionais de fomento. $^{26}$

O complexo industrial-bélico se assenta num tripé composto pela EMBRAER (Empresa Brasileira de Aeronáutica), que foi a pioneira, pela IMBEL (Indústria Brasileira de Material Bélico) e pela ENGEPRON (Empresa Gerencial de Projetos Navais). As três

26 O complexo industrial-militar apóia-se numa rede de órgãos de pesquisa e desenvolvimento de caráter militar. O Estado-Maior das Forças Armadas (EMFA) possui uma agência coordenadora denominada Sub-chefia de Assuntos Tecnológicos, cujo dirigente faz parte do Conselho Nacional de Desenvolvimento Científico e Tecnológico. O Exército, por sua parte, inclui em sua estrutura o Departamento de Ensino e Pesquisa, que controla o Instituto Militar de Engenharia (IME), o Instituto de Pesquisa e Desenvolvimento e o Centro de Testes de Mísseis de Marambaia. Quanto à Força Aérea, o seu Departamento de Pesquisa e Desenvolvimento é o principal centro responsável por todo o conjunto de pesquisa e desenvolvimento do Centro Técnico Aeroespacial, composto de seis grandes centros, institutos e comissões. Na Marinha, a política de pesquisa e desenvolvimento é conduzida pelo Alto-Comando e seus órgãos principais, como a Diretoria de Eletrônica e Comunicações e o Instituto de Pesquisas da Marinha. Cf. Clóvis Brigagão, op. cit., pp. 22-23. 
empresas funcionam como holdings dos setores industriais mantidos pelas três Armas. Assim, à IMBEL, criada em 1975, foram transferidas as fábricas de material bélico antes mantidas diretamente pelo Exército: Andaraí, Estrela e Centro de Pesquisa e Desenvolvimento de Comunicações (no Rio de Janeiro), Piquete (em São Paulo), Juiz de Fora e Itajubá (em Minas Gerais). Da mesma forma, a ENGEPRON, criada em junho de 1982, passou a reunir o Arsenal de Marinha, a Fábrica de Artilharia e o Centro de Munição da Marinha, sediados no Rio de Janeiro.

Convém assinalar que se verifica uma divisão do trabalho entre as três Armas, divisão que define as preocupações de cada uma e que modela seus respectivos pesos político-militares. Assim, a Força Aérea se volta para os mísseis, sistemas teleguiados, projetos de aviões de reconhecimento tático e conversíveis para operações de guerra em cenários limitados, mas não desenvolve projetos tecnologicamente mais ambiciosos ou de uso aeronaval, a exemplo do modelo Skyhawk. A Marinha. se dedica aos sistemas eletrônicos - computação e comunicação - e dessa ênfase surgiu a indústria nacional de computadores. E o Exército, a equipamentos de guerra convencional (blindados e outros veículos, armas e equipamentos de uso pessoal, material de artilharia).

A criação dessas empresas estatais significou um passo fundamental no sentido de desenvolver a indústria militar brasileira. Por um lado, visava à modernização da estrutura preexistente, ou seja, as diversas fábricas de material bélico, algumas bastante antigas, pertencentes às três Armas. Essa estrutura passou a ser coordenada segundo uma política que dá ênfase à transferência de tecnologia e à nacionalização de equipamentos. Dessa política, por sinal, derivam problemas na definição do que é "empresa nacional" (seria caracterizada pelo domínio da tecnologia, pela composição do capital, pela composição da direção, pela área de atuação, pelos recursos humanos empregados ?), cujo foco candente tem sido a área da informática. Por outro lado, a criação da EMBRAER, da IMBEL e da ENGEPRON visava ao fortalecimento da indústria bélica como um todo, cuja maior parcela é de propriedade privada, através de assistência técnica e financeira, de estímulo à pesquisa e desenvolvimento, bem como de subsídios sob a forma de estudos, projetos e serviços contratados.

Desse processo decorre a constituição do que se poderia chamar de "complexo empresarial-militar", uma articulação de interesses da corpo ração militar e de uma vasta rede de empresários privados, rede essa que os Grupos de Mobilização Industrial procuram articular, envolvendo fabricantes de armamentos como tais e fabricantes de componentes específicos para a montagem de armamentos. $^{27}$ Um episódio recente ilustra a consolidação desse

27 A horizontalização da indústria militar brasileira, isto é, o aproveitamento de componentes fornecidos pelas mais variadas indústrias, é mencionada como fator básico da sua competitividade no mercado internacional. Caso interessante é o da Vigorelli, tradicional fabricante de máquinas de costura, cuja participação no setor bélico como fornecedora de equipamentos de pontaria para canhões veio à tona em virtude da crise 
complexo: a nomeação, para dirigir a IMBEL, do engenheiro José Luiz Whitaker Ribeiro, um civil, que é também presidente da ENGESA (Engenheiros Especializados S.A.), empresa privada nacional que detém metade do mercado mundial de blindados leves. Dirigida desde sua criação por generais em fim de carreira, a IMBEL guardava certo caráter de repartição pública, com prejuízos cobertos pelo Exército, seu principal acionista. A nomeação de Whitaker Ribeiro, segundo fontes militares, destinava-se a limitar os vínculos da IMBEL com o Exército e assim fazê-la funcionar como uma empresa privada, voltada para a exportação. ${ }^{28}$ Ao tomar posse, Whitaker Ribeiro declarou ser função precípua da empresa o auxílio à indústria bélica privada, objetivo também destacado pelo ministro do Exército, General Walter Pires, que reiterou em seu discurso as intenções que levaram à criação da empresa. ${ }^{29}$

Uma vez implantada a estrutura básica, o Brasil duplicou, entre 1974 e 1980, seus gastos com a defesa, diminuindo ao mesmo tempo suas importações nessa área para 4,5\% do total. Foi também desenvolvida uma política agressiva de vendas de armamentos, que assume importância no contexto da política externa, especialmente

financeira da empresa Cf. Roberto Pereira, "As Crises em meio à Euforia", Folha de S. Paulo, 7.6.1982, p. 10. Outro caso exemplar é o da D. F. Vasconcelos, conceituada indústria de instrumentos óticos de alta precisão, que fornece componentes vitais tanto para as Forças Armadas brasileiras quanto para as de outros países.

28 Jornal do Brasil, 22.10.1982, p. 21.

29 Folha de S. Paulo, 28.10.1982. com relação á Ásia e à África. A presença da indústria bélica brasileira se amplia no mercado internacional, fortemente subsidiada pelo Estado e ajudada pela Política Nacional de Exportação de Material de Emprego Militar (PNEMEM), executada a partir do Conselho de Segurança Nacional e organismos como a CACEX. No que se refere à derrianda interna, os gastos militares giram em torno de $12 \%$ do orçamento federal ${ }^{30}$.

Ainda a ser destacada entre as grandes iniciativas da fase pós1964 foi a criação de um moderno sistema de informações.

A "comunidade de informações" surgiu como um desdobramento da instituição militar. Elas se bifurcaram. A comunidade tornou-se estrutura auto-suficiente, embora funcionando à sobre das Forças Armadas ${ }^{31}$.

A constituição do Serviço Nacional de Informações (SNI), em 1964, pode ser vista como inovação-chave dentro desse processo. O SNI combinava as funções de uma agência central de informações com as de um órgão assessor para formulação de políticas nacionais. Seu fundador e primeiro chefe foi o general Golbery do Couto e Silva, que se cercava de um grupo bem articulado de oficiais, composto, entre outros, do general Ernesto Geisel (à época chefe da Casa Militar da Presidência), dos coronéis João Batista Figueiredo e

30 Clóvis Brigagão, "A Corrida Armamentista Mundial", Jornal de BrasflÜ1, 23.5.82, p.12.

31 Sobre esse ponto, ver René A. Dreifuss, op. cit., capo IX e X; e Alexandre de Souza Barros, op. cit., pp. 210-217. 
Ivan Perdigão, dos tenentes-coronéis Danilo Venturini e Octavio Medeiros, do major Newton Cruz e do capitão Heitor Ferreira.

O SNI se propôs a ser — e o conseguiu — um centro de influência crucial na formulação de políticas em cada área da vida social, política e militar do país, tomando-se o esteio político das Forças Armadas. Foi estabelecida uma rede de informações nos ministérios, nas autarquias e nas agências administrativas do governo, bem como na área militar, no movimento sindical, no movimento estudantil e em outros segmentos selecionados da população, transformando o Serviço em um superministério, intocado e intocável pelos Poderes Legislativo e Judiciário e não responsável perante as Forças Armadas.

Quando de sua criação, o SNI serviu para se antecipar a algumas das funções do Serviço Federal de Informação e ContraInformação (SFICI), que funcionara até então como um embrião de um órgão central de informações. A necessidade de uma instituição capaz de concorrer com o SFICI tomou-se aguda, não apenas porque este último era um produto do regime' deposto, mas sobretudo porque o general Costa e Silva, o novo ministro da Guerra, havia indicado um de seus homens, o coronel Jayme Portella, para a Secretaria do Conselho de Segurança Nacional, com supervisão sobre o SFICI, procurando estabelecer aí uma base de apoio. ${ }^{32}$

32 Substituído nessa função quando o general Ernesto Geisel assumiu a chefia da Casa Militar do presidente Castello Branco, Portella foi
A médio e longo prazos, um órgão central de informações era requerido pela opinião militar no sentido de assumir um papel-chave na implementação da doutrina de Segurança Nacional disseminada pela ESG. Além disso, a comunidade de informações poderia preencher atributos políticos que as Forças Armadas, com sua natural rigidez, não possuíam. O comportamento institucional, a hierarquia e as normas corporativas não dotavam as Forças Armadas do nível adequado de flexibilidade para que elas se envolvessem enquanto tais na política. Ademais, esse envolvimento, quando se verificou, reforçava as posições dos extremistas de direita - a "linha-dura"33 — porque a ação militar eficiente em assuntos não-militares demandava a manutenção ou o aprofundamento dos aspectos de confrontação "militar" do sistema político, em contraste com os aspectos que se poderia designar como "políticos" e que comportam a negociação e o compromisso. O sistema de informações, desse modo, poderia sobrepor-se à rigidez das Forças Armadas, sem recorrer a ações extremistas, sem fortalecer as correntes de direita e, talvez mais

encarregado por Costa e Silva de chefiar o seu Gabinete em Brasl1ia. O ministro determinou-111e logo que "lhe apresentasse, quanto antes, um plano para substituição de todos os comandos situados nas diferentes guarnições do interior do país e de oficiais superiores comprometidos com o governo deposto". Jayme Portella de Mello, A Revolução e o Governo Costa e Silva Rio de Janeiro, 1979, p. 214. As medidas de Costa e Silva iriam colocá-lo eventualmente em rota de colisão com o grupo castelista que controlava o núcleo do poder.

33 A expressão "linha dura" não seria a mais apropriada para designar este fenômeno porque sugere uma constante, tanto em termos de adeptos quanto de objetivos. 
importante a longo prazo, sem permitir que facções nacionalistas dissidentes das Forças Armadas ganhassem espaço na condução da economia e do sistema político.

Finalmente, o SNI poderia funcionar mesmo depois que as Forças Armadas se desengajassem da intervenção ostensiva e "retomassem" aos quartéis. Paralelo à vida partidária regular, manteria inclusive o andamento da política na ausência de partidos, ou num quadro político de partidos frágeis. O SNI, de fato, poderia atuar como um partido político, talvez o único órgão militar capaz de fazê-lo, funcionando como um foco de apoio e de informação para o regime e, ao mesmo tempo, como um agente de manipulação do sistema político.

Ao lado da criação do SNI e da expansão do que pode ser chamado de "comunidade de informações e segurança", outro corpo político e normativo adquiriu extraordinária projeção. Referimo-nos ao Conselho de Segurança Nacional e à sua Secretaria-Geral. ${ }^{34}$

De acordo com Walder de Goes, "é deste órgão que emanam as principais opções estratégicas do Estado e é em seu âmbito que as burocracias civil e militar se articulam, produzindo orientações consensuais. Seu funcionamento é secreto, as informações que ele manipula são produzidas pelo Estado e não existe nenhum tipo de representação do empresariado ou de quaisquer outros setores da

34 Sobre o assunto, v. Walder de Goes, O Brasil do General Geisel, Rio de Janeiro, 1978, espec. pp. 32-42. sociedade civil. (...) No próprio Conselho de Segurança, o poder é dividido em fatias servidas a tecnocratas e militares, consensualmente, conforme as informações que uns e outros controlam e conforme as diferentes áreas de interesse sejam consideradas prioritárias mais para uns do que para outros. (...) A política de informática, por exemplo, totalmente formulada pelo CSN, é de domínio exclusivo dos militares. Eles monopolizam a produção e métodos. Na realidade tratava-se de tendências de opinião variadas, reunidas circunstancialmente em torno de chefias "duras".Estas tendências e articulações eram cambiantes e renováveis em termos de gerações, em contínua reformulação e reaglutinação política e recomposição organizacional e informações sobre o assunto e beneficiam-se do entendimento, consensual no Estado, de que lhes cabe a gerência de todas as questões - como a informática diretamente pertinentes aos interesses da segurança nacional, stricto sensu" (grifos no original). ${ }^{35}$ Ainda segundo W. de Goes, a formulação de diretrizes de política externa é outra área de ação e preocupação do CSN. Diretrizes de política externa relacionadas a questões de energia, especialmente a questão nuclear, são fixadas pelo secretariado-geral do CSN.

É interessante notar que a reformulação de atribuições do CSN,

35 Walder de Goes, "Empresários, Militares e Tecnocratas: Colaboração ou Confronto?", trabalho apresentado no $5^{\circ}$. Encontro Anual da Associação Nacional de Pós-Graduação e Pesquisa em Ciências Sociais, Nova Friburgo, 1981, pp. 8-12. 
que se deu nos últimos meses, abre a perspectiva para este órgão servir de canal alternativo da articulação e informação políticas numa região sensitiva como é a do Norte/Nordeste, e num setor conflitivo como é o fundiário através da criação de "Ministério da Terra", quebrando o monopólio partidário e as possíveis cobranças políticas ao governo por parte das seções regionais do PDS.

\section{As Forças Armadas no processo de abertura política}

O processo de abertura, iniciado com a supressão do Ato Institucional $\mathrm{n}^{\mathrm{o}} 5$, resulta em parte da síndrome de tensão-pressão, ao mesmo tempo que a reproduz em novo contexto.

A abertura pode ser vista como resultante da síndrome na medida em que as Forças Armadas foram percebendo a impossibilidade de continuar a desempenhar a multiplicidade de papéis - notadamente na administração do Estado - que haviam assumido, em uma sociedade complexa e problemática que elas próprias ajudaram a modelar. O impacto da recepção incompleta de papéis sobre a instituição exacerbou a disfuncionalidade do processo. Entre outros aspectos, o velho problema da autonomia da instituição foi agravado, embora sob outra forma: o nítido engajamento das Forças Armadas com seus aliados preferenciais, sobretudo o bloco empresarial, opunha-se à imagem nacional da instituição, acima dos interesses particulares. Mesmo considerando que esse engajamento se dava a partir de uma posição de força, a percepção interna à instituição era a de que para a grande maioria da população — os outsiders do sistema - esse relacionamento era discutível e levava a formar uma imagem diversa daquela que os militares desejavam projetar. Essa tensão interna em torno da questão da autonomia era avivada pela existência de pressões cruzadas, seja das parcelas identificadas com o complexo empresarial-militar, seja da "linha dura" isolacionista, seja, enfim, dos setores não alinhados com estas posições.

A abertura oferece às Forças Armadas uma perspectiva de solução desses problemas. Entretanto, ela realimenta a síndrome de tensão-pressão no sentido de que, se há um movimento interno para confinar-se ao desempenho dos papéis legítimos da instituição, há ao mesmo tempo a pressão dos setores que não concordam com essa demissão, a ela resistindo de várias formas. Examinemos esse ponto por um momento.

O crescimento desmesurado da área de segurança e informações, em virtude dos papéis assumidos pelas Forças Armadas enquanto guardiãs da ordem, administradoras do Estado e governo da nação, introjetou a síndrome de tensão-pressão na própria corporação. Isso ocorreu, em boa medida, por causa da autonomia de ação e decisão lograda pela área de segurança e informações, cujos resultados podem ser medidos pela frase lapidar "eu criei um monstro", atribuída ao general Golbery do Couto e Silva, idealizador do SNL É precisamente na tentativa de enfrentar as distorções geradas ao longo de um processo de acentuado envolvimento no universo político que se configura o esforço de certos setores, tendo à 
frente os generais Ernesto Geisel e Golbery do Couto e Silva, para desencadear uma grande manobra social de abertura do sistema, com o objetivo último de institucionalizá-lo. Por conseguinte, pode-se discernir dois grandes eixos em contraposição, um deles encastelado nas zonas de penumbra de segurança e informações, e outro, que se lhe opõe, atuando à luz do dia e procurando iluminar os pontos de atrito. Para tanto, esse último procura uma base de apoio na sociedade civil, bem como correias de transmissão confiáveis nos quadros político-partidários. ${ }^{36}$ Busca uma caixa de ressonância social que produza um efeito de demonstração no meio militar. Nessa perspectiva, a sociedade, suas demandas já articuladas e seus anseios legítimos seriam aproveitados para a manobra de isolamento da estrutura radical à direita do espectro político, localizada no bunker ideológico. É justamente aí, no atrito desses dois eixos, que se recria a síndrome de tensão-pressão.

Retomando o curso do nosso argumento, as Forças Armadas, no plano político-ideológico, têm como necessidade preliminar a redefinição de seus papéis e funções num sistema predominantemente civil e crescentemente pluralista. Trata-se de estabelecer um roteiro de desengajamento dos papéis incompletamente assumidos e de reencontrar-se nas funções consideradas legítimas, velhas e novas.

36 O exemplo mais expressivo é dado pela atuação desenvolvida pelo Senador Petrônio Portella no encaminhamento da abertura, em estreita conexão com os Generais Geisel e Golbery.
Além dessa definição, as Forças Armadas estão em face do problema de legitimar esses papéis e funções perante a sociedade. A perspectiva colocada pelo processo de abertura é exatamente a da responsabilidade (accountability) do Estado em face da sociedade. Aumenta a visibilidade do que ocorre na esfera estatal; as decisões são objeto de debate e crítica. No tocante a esse aspecto da legitimação, uma definição básica a ser promovida pelas Forças Armadas consiste em optar por um de dois caminhos: ou elas se afirmam como uma instituição da sociedade, nos termos de sua retórica cívica tradicional, mas implicando profundas consequiências práticas, ou elas se reconhecem como instituição na sociedade, ao lado de outras (a Igreja Católica, por exemplo), o que corresponderia à sua ação pós-1964, fonte, como vimos, de tensão-pressão internamente e de turbulência no sistema político, em virtude da tendência à intervenção.

Passando agora ao nível organizacional, constata-se desde logo que os entraves à eficiência da instituição militar enquanto organização profissional, aos quais fizemos referência na primeira parte, persistem, embora sob nova roupagem. Oficiais têm sido prestigiados ou punidos de acordo com critérios político-ideológicos, não mais à revelia da instituição, mas com freqüência à revelia de padrões profissionais ou de mérito. Mais ainda, verifica-se a tendência, por parte da própria cúpula militar, de fixar critérios de promoção acentuadamente burocratizantes, com o fito de estimular atitudes de conformismo da oficialidade à sua política. Dessa forma, 
cerceiam-se a inovação e a criatividade, atributos desejáveis de um oficial graduado, e reforçam-se vícios ideologizantes e burocratizantes. A implicação é que continua distante o objetivo histórico, almejado por gerações de militares brasileiros, de profissionalização criativa e dinâmica de sua corporação. ${ }^{37}$

No plano interno, o problema maior que se coloca agora para a instituição militar é o de definir e legitimar seus papéis e funções no âmbito da corporação (os "públicos internos") e no campo mais geral do Estado. As Forças Armadas se modernizaram rápida e eficientemente; contudo, dado que o país não enfrenta ameaças de caráter militar, emerge a questão do objetivo desse potencial. À falta do inimigo interno dos anos 60 e 70, qual seria esse objetivo? Sustentar a projeção da nação, pelo poderio bélico?

Certamente a variável MCI (Movimento Comunista Internacional), invocada por alguns setores militares como ameaça permanente que se exprime em termos de cenários hipotéticos, tanto em termos de um confronto Leste-Oeste quanto de seus desdobramentos internos (guerrilha, terrorismo) ou de combinação das duas, não tem muitas condições políticas de se perpetuar, a não ser por provocação imediata. Mas, mesmo no caso de permanecer como variável determinante, não poderá ser a única, haja vista o

37 Casos veículados pela imprensa ilustram essa postura Dois deles, por se referirem a personalidades militares conhecidas, ganharam destaque: os episódios de eliminação dos Generais Andrada Serpa e Octavio Costa do serviço ativo. Oficiais de opiniões diferentes, tinham em comum a iniciativa e a independência que lhes foram fatais. conflito das Malvinas, que revelou de forma imprevista e contundente a possibilidade de confrontos entre aliados ou participantes de um mesmo consenso global estratégico. Esse mesmo episódio, por outro lado, iluminou de forma dramática a incapacidade técnica, logística e profissional de Forças Armadas, como as da Argentina, condicionadas ao longo de anos para a luta no front interno.

Além disso, a dramática situação social do país, ao lado de problemas candentes derivados do modelo econômico, poderão suscitar em vários níveis do universo militar preocupações de outra ordem, cujo foco de referência será aquele do encaminhamento dessas questões, redefinindo-se opções e prioridades. Sob esse aspecto, são ilustrativas certas observações recentes do general Andrada Serpa, segundo o qual o problema brasileiro é muito mais que um problema de dificuldades econômico-financeiras, sendo sobretudo de natureza sócio-cultural e política: "Sócio-cultural porque o povo brasileiro é o mais espoliado externamente e o mais sangrado internamente, e a classe política dirigente, à qual pertenço, é a mais hipócrita, insensível e incompetente que se pode encontrar numa nação, o que impede o Brasil de retomar os seus destinos". Para o general Serpa, "qualquer rumo de redenção da atual situação do Brasil só será encontrado pelo governo que tiver a coragem de enfrentar os banqueiros e as multinacionais e procurar construir um projeto nacional, de médio prazo ... que seja uma alternativa válida de assegurar a independência energética e tecnológica do país, 
rejeitando as exportações com transferência de renda e trabalho nacionais e deixando de emitir papéis sem lastro que, aliado aos lobbies complexos da economia, discriminam a economia brasileira". ${ }^{38}$

O preciso papel das Forças Armadas no processo de abertura é ponto a ser debatido. Observamos o seu desengajamento de certas tarefas e sua reintegração às suas funções legítimas. A evoluir essa tendência, teríamos algo como uma postura arbitral por parte da instituição militar, regulando de forma não ostensiva o jogo sóciopolítico, de acordo com regras previamente estabelecidas. Uma qualificação indispensável a essa imagem, todavia, tem a ver com o fato de que o código de regras do jogo não se acha claramente definido. As regras estão em fase de definição, de forma algo empírica, e há a expectativa de que deverão consolidar-se numa mudança constitucional. Esse processo de fixação das regras é condicionado de diversas maneiras pelas Forças Armadas, inclusive por sua margem de influência sobre o governo. Pode-se especular, ao lado disso, sobre sua atitude em face da sucessão presidencial de 1985, bem como de uma futura Assembléia Constituinte, externando posições em ambos os casos e afirmando limites não negociáveis para as regras do jogo 39 .

38 A Tarde (Salvador), 19.10.1982, p. 3.

39 Uma possibilidade é a do retorno ao regime parlamentar, apesar da preferência tradicional dos militares por um presidencialismo forte. Nesse caso, haveria um Presidente, Chefe do Estado e estabilizador da ordem, e
A função de arbitragem certamente supõe focos potenciais de atrito dentro da instituição, o que confere atualidade à ideia da síndrome de tensão-pressão. Entre esses focos, indiquem-se o relacionamento com a comunidade de informações, a questão do orçamento militar, a presença de militares na área empresarial, a postura perante setores políticos tidos como antagônicos. Ilustração disso é dada pelo entrevero ocorrido no Superior Tribunal Militar, em 1981, em torno do inquérito do Riocentro ${ }^{40}$, e aparentemente pelos distúrbios verificados na apuração dos votos do pleito de 1982, no Rio de Janeiro.

Mais ainda, se a arbitragem se contém dentro dos marcos da ordem vigente, a própria garantia dada pelos militares à reprodução dessa ordem implica uma parcialidade em favor de grupos que ela privilegia. Assim, por mais discreta e hábil que seja a arbitragem, ela deixará de ser vista como efetivamente neutra, nacional. Emerge disso o problema da legitimidade de que tratamos.

Dado que o processo de abertura oferece perspectivas para solucionar tais contradições, a solução mais ampla terá de passar por

um Primeiro-Ministro, Chefe do Governo e cabeça da administração pública.

40Quando do julgamento do processo referente à tentativa de atentado a bomba no Riocentro, o Ministro Júlio de Sá Bierrenbach, da Marinha, adotou a postura de árbitro diante dos autos. O fato de Ministros pertencentes ao Exército tomarem essa neutralidade como ofensiva à sua Arma significou um endosso a um inquérito promovido intra-murol, cujo resultado foi interpretado como parcial pela opinião pública. A atitude de neutralidade de Bierrenbach não foi assimilada, caracterizando-se então a parcialidade de seus colegas. 
uma discussão interna sobre a posição das Forças Armadas diante do Estado e da sociedade. Sobre a alternativa de ser uma instituição da sociedade, como sublinhamos, de conciliar-se com as demandas da cidadania, de conviver com a oposição. Tanto mais quando, nas eleições de 1982, oficiais candidataram-se por partidos de oposição e, examinando-se os resultados eleitorais, tudo indica que parte dos militares deu seu voto à oposição. ${ }^{41}$ Ser uma instituição da sociedade implica o reconhecimento da condição de cidadão do funcionário militar, portanto de seu legítimo direito de optar.

A condição para se alcançar essa definição é a abertura do diálogo com os diversos segmentos da sociedade, indo além dos aliados preferenciais de hoje. A intenção de promover esse diálogo, por sinal, foi revelada pelo general Alzir Benjamin Chaloub, comandante da Escola Superior de Guerra. ${ }^{42}$ Segundo o general Chaloub, "a partir do próximo ano, a Escola Superior de Guerra começará a ter em seus quadros, na qualidade de debatedores, representantes dos sindicatos, empresários e banqueiros", porque a ESG "não dá primazia a nenhuma classe. (A ESG) é um laboratório de ideias, que, sem apontar soluções, deve estudar e analisar projetos econômicos e políticos para o país. (A ESG) deve estudar o exercício do poder". Dentro dessa perspectiva, de levar à Escola pessoas que "pensam diferentemente", como d. Paulo Evaristo Arns, cardeal-

41 Cf. coluna do jornalista Adirson de Barros no Jornal Última Hora, 19.11.82

42 Jornal do Brasil, 21.4.1982, p.5. arcebispo de São Paulo, e o deputado Ulisses Guimarães, presidente nacional do PMDB, ó general Chaloub admitiu que pretendia convidar o presidente do Partido dos Trabalhadores, Luiz Inácio da Silva ("Lula"), como "um dos primeiros representantes autênticos dos trabalhadores, o primeiro que teve a coragem de se projetar".

Saberemos oportunamente se essas intenções serão transformadas em realidade ou se se mostrarão mero fogo-de-palha. Em todo caso, desse diálogo poderia resultar um incremento da legitimidade social das Forças Armadas. Contudo, a legitimação deve ser mútua, de mão dupla, o que significa que a participação dos diversos setores sociais na arena política deverá ser correspondentemente absorvida e reconhecida pelas Forças Armadas enquanto tais. Isso implica uma evolução, sem dúvida profunda, da forma prevalecente de política tecnificada de que os militares são participantes privilegiados — para uma política efetivamente pública.

Como conclusão, pode-se sugerir que a superação da síndrome de tensão-pressão reside em dois processos interligados: de um lado, o estabelecimento de uma ordem política aberta e participativa; de outro lado, a reintegração das Forças Armadas às funções definidas como legítimas, favorecendo a adoção de um padrão de comportamento profissional por parte dos militares. 


\section{Desenvolvimento, urbanização e mudanças na estrutura do emprego: a experiência brasileira dos últimos trinta anos ${ }^{1}$}

Vilmar Faria $^{2}$

O objetivo deste trabalho é examinar de forma sucinta dois aspectos interligados do processo recente de transformação social no Brasil: o processo de urbanização e as mudanças na estrutura do emprego. A importância destes dois aspectos, além de intrínseca, repousa no fato de que eles constituem processos básicos para a configuração da estrutura social.

Além dos dois aspectos mencionados analisarei também, embora de forma breve e indicativa, alguns problemas relativos à situação de pobreza e de marginalidade, já que estes últimos são centrais para uma avaliação dos resultados do crescimento econômico brasileiro dos últimos trinta anos e estariam ligados à dinâmica da urbanização e do emprego.

Os organizadores desta coletânea pretendiam que a análise se centrasse no período pós-64. Entretanto, dado o caráter estrutural dos processos analisados, pareceu-me de bom alvitre adotar um horizonte de tempo mais amplo para que se possa melhor avaliar o rumo e o ritmo das transformações.

1 Trabalho apresentado no $44^{\circ}$ Congresso Internacional de Americanistas, Manchester, Inglaterra, 5-10 de setembro de 1982.

2 Professora do Depto. de Ciências Sociais da UNICAMP.
Este trabalho está organizado em quatro partes. Na primeira, procuro apresentarem dados que ilustrem a magnitude e o sentido das transformações ocorridas entre 1950 e 1980, relevantes para os aspectos centrais do trabalho. Na segunda parte, trato de descrever e analisar as mudanças na estrutura urbana brasileira, dialogando com a hipótese da crescente concentração da população urbana no Brasil como decorrência das peculiaridades do processo de desenvolvimento recente. Na terceira parte, apresento dados e analiso a dinâmica da criação do emprego nos últimos trinta anos, tendo como pano de fundo a tese da insuficiência dinâmica do setor secundário na criação de novos empregos. Finalmente, na quarta parte, procuro avançar algumas conclusões, introduzindo na discussão o problema da pobreza e da exclusão, chamando a atenção para o caráter particularmente perverso da sociedade de consumo e de massas que vai se configurando no país.

Os dados apresentados e o argumento desenvolvido pretendem, em resumo, qualificar a hipótese de que o processo de desenvolvimento recente no Brasil acarretou maior concentração da população urbana, insuficiência crescente na criação de empregos industriais e concentração da pobreza urbana nas áreas metropolitanas do país. Sustento, em contrapartida, que os elevados níveis de pobreza, dispersa por todo o sistema urbano, respondem a conjunto mais complexo de fatores.

Entretanto, dada a natureza limitada do trabalho, entre aprofundar a discussão teórica e apresentar dados e informações 
relevantes, optei pelo segundo, na expectativa de que isso possa servir de base para uma discussão mais ampla do tema.

\section{Trinta anos de crescimento e mudança}

Ao terminar a década do imediato pós-guerra, a expressão "país essencialmente agrícola" podia ainda aplicar-se para caracterizar superficialmente o Brasil, embora ela fosse inadequada se tomássemos em conta aspectos mais profundos, em especial a natureza e o sentido de processos já em curso. Os dados apresentados na Tabela $1^{3}$ assim o justificam.

Para começar, do total de domicílios existentes no país em $1950,62,8$ por cento classificavam-se como rurais; 78,5 por cento da população residiam em áreas rurais, vilas ou cidadezinhas de menos de 20000 habitantes e a participação das ocupações ligadas à agropecuária e à extração, no total das ocupações, atingia a cifra de 57,81 por cento.

No que tange à estrutura da economia, basta assinalar que as vendas de café constituíam cerca de 60 por cento do total exportado pelo país, a PEA (população Economicamente Ativa) agrícola

3 Para este trabalho utilizei uma parte de outro trabalho meu, preparado para o Simpósio "A Questão Migratória no Brasil: Migrações Internas e a Ação do Estado", promovido pelo CNPq, em Brasília, em dezembro de 1981. Nesta primeira parte, utilizei informações e me vali de vários trabalhos para ganhar melhor compreensão sobre as transformações econômicas recentes. Entre eles cabe destacar: Serra, 1981; Conceição Tavares, 1978; Bonelli e Malan, 1976; Draibe, 1981; Belluzzo e Mello, 1977. representava 59,9 por cento da PEA total (enquanto a PEA na indústria de transformação mal ultrapassava os 9,0 por cento do total) e a contribuição da agricultura para a Renda Interna — em 1949, apreços correntes — alcançava 24,9 por cento (em comparação com a contribuição da indústria de transformação, que era ligeiramente superior a 20,0 por cento). A indústria de transformação do país, embora importante e decorrente do esforço de industrialização dos trinta anos anteriores estava, ainda, marcadamente ligada à produção "tradicional": os bens não duráveis de consumo representavam 72,8 por cento do total do valor da produção industrial (em Cr\$ de 1970). Os bens de capital contribuíam com apenas 2,5 por cento para o valor total da produção industrial e os bens duráveis de consumo com apenas 4,3 por cento.

Trinta anos depois, a geração que aprendera na escola de primeiro grau sobre o caráter essencialmente agrícola do país vivia num país totalmente modificado: o Brasil em 1980 já ocupava um lugar entre as dez maiores economias industriais do mundo, em termos de volume do produto industrial, embora se deva ter cuidado sobre as implicações disto. Essa mudança se reflete nos indicadores da Tabela 1. 
Tabela 1

INDICADORES ESTRUTURAIS DO PERFIL DA SOCIEDADE BRASILEIRA

\begin{tabular}{|c|c|c|}
\hline \multirow[b]{2}{*}{ Indicador } & \multicolumn{2}{|c|}{ Ano } \\
\hline & $\begin{array}{c}\text { Circa } 1950 \\
\%\end{array}$ & $\begin{array}{c}\text { Circa } 1980 \\
\%\end{array}$ \\
\hline 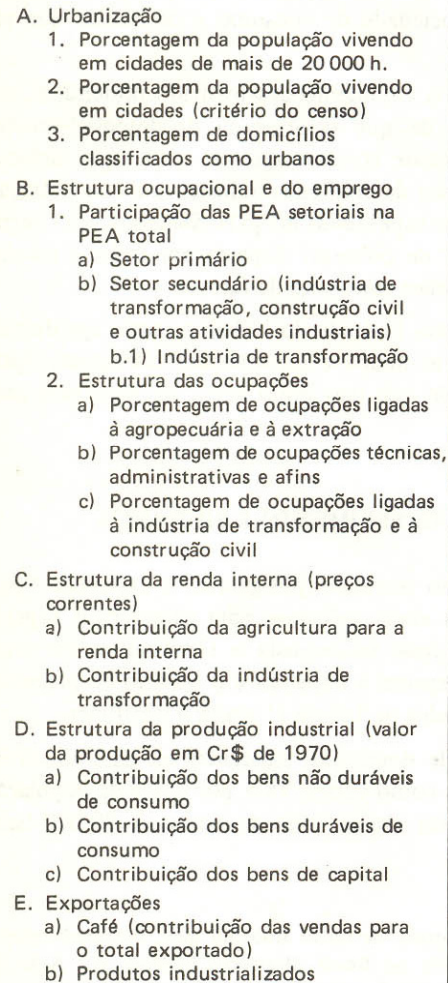 & $\begin{array}{l}21,5 \\
36,2 \\
37,13 \\
59,90\end{array}$ & $\begin{array}{l}(31,08) \text { * } \\
(20,70)^{*}\end{array}$ \\
\hline
\end{tabular}

Em primeiro lugar, em 1980, 68,9 por cento dos domicílios existentes no país classificavam-se como urbanos, 67,7 por cento da população viviam em áreas consideradas como urbanas pelos critérios dos Censos Demográficos e 45,7 por cento viviam em cidades de 20000 habitantes ou mais. Como mostrei em trabalho anterior (FARIA, 1982), em 1980 havia no Brasil trinta aglomerações urbanas com mais de 250000 habitantes, nas quais viviam mais de 42 milhões de pessoas, representando 35 por cento da população brasileira. Só este contingente representava quatro vezes a população urbana do país em 1950 !

Em segundo lugar, a contribuição das vendas de café para o total exportado caíra para 13,4 por cento, enquanto a participação dos produtos industrializados no valor total exportado atingira a cifra de 56,5 por cento. A participação da PEA no setor agrícola e extrativo, por sua vez, baixara para 29,93 por cento, subindo a participação da PEA no conjunto do setor secundário para 24,37 por cento do total da PEA. Da mesma forma, as ocupações ligadas à agropecuária e à extração representavam apenas 31,08 por cento do total das ocupações - caindo mais de 25 pontos percentuais em trinta anos enquanto dobrara o percentual de ocupações técnicas, administrativas, científicas e aquelas ligadas à indústria de transformação e à construção civil, representando, em conjunto, quase 20 por cento do total das ocupações. Em 1980, a contribuição da indústria de transformação para a Renda Interna, a preços correntes, alcançava 26,3 por cento do total, praticamente o dobro da cifra atingida pelo setor primário: 13,2 por cento.

Finalmente, modificara-se profundamente a estrutura da produção industrial. A participação dos bens não duráveis de 
consumo no valor da produção industrial, em Cr\$ de 1970, caíra pela metade desde 1950, representando 34,4 por cento. Elevara-se consideravelmente a contribuição da indústria de bens duráveis de consumo (para 13,5 por cento) e da indústria de bens de capital (14,7 por cento) que, em conjunto, passam de 6,8 por cento em 1950 para 28,2 por cento em 1980 .

Estas transformações, ocorridas em curto espaço de tempo, fazem do Brasil, como assinala Serra, "uma espécie de paradigma de país de industrialização retardatária onde o crescimento econômico e a diferenciação das forças produtivas têm apresentado uma extraordinária vitalidade". (SERRA, 1981) De fato, entre 1947 e 1980, o Produto Interno Bruto brasileiro cresceu a uma taxa média de 7,1 por cento ao ano, taxa esta superior à do conjunto dos países capitalistas desenvolvidos e subdesenvolvidos, excetuando-se entre estes os países produtores de petróleo.

Este crescimento foi comandado pela indústria de transformação que, no conjunto, cresceu a uma taxa média de 8,5 por cento ao ano: na verdade, o crescimento brasileiro no período foi profundamente marcado pela notável expansão da indústria de bens duráveis de consumo, que cresceu à taxa média de 15,3 por cento ao ano, atingindo taxas de crescimento superiores a 23,0 por cento ao ano nos momentos expansivos dos ciclos que ocorreram no período (1955-62 e 1967-73). Também os setores de bens intermediários e de bens de capital cresceram a taxas médias elevadas (10,5 e 12,8 por cento ao ano, respectivamente).
Um crescimento de tal magnitude, ocorrendo a ritmo tão acelerado na periferia da economia capitalista mundial, não poderia dar-se sem que tivessem lugar, por um lado, profundas modificações quantitativas e qualitativas na estrutura espacial, demográfica e social do país e, por outro, o agravamento de antigos e o surgimento de novos desequilíbrios setoriais, regionais e sociais. A análise destas modificações e desequilíbrios torna-se extremamente importante, especialmente agora que o chamado modelo brasileiro de desenvolvimento parece mergulhado numa crise sem precedentes na história do país. Entretanto, foram tamanhas as modificações e parecem ser tantos os desequilíbrios que este processo preservou, gerou ou agravou, que seria impossível querer abarcar a todos. Por isso mesmo, procurarei examinar apenas dois aspectos interligados da mudança social ocorrida: por um lado, o ritmo, as características e os desequilíbrios do processo de urbanização no período, em termos das modificações por que passou o sistema urbano brasileiro; por outro lado, a dinâmica da criação de empregos e as mudanças gerais na estrutura ocupacional do país.

Esta análise, embora descritiva e geral, parece-me justificada porque é comum atribuir-se à dinâmica de ambos os processos papel importante na geração e agravamento de desequilíbrios sociais, estruturalmente provocados pelo modelo de desenvolvimento que prevaleceu. O argumento a este respeito, embora simplificador, é bastante difundido. Como se sabe, o processo brasileiro dos últimos trinta anos, baseado na expansão da indústria de bens duráveis de 
consumo e na indústria de bens de capital, exigiu e gerou acentuada concentração da renda. Tais indústrias, como também é conhecido, desenvolveram-se dependentes — direta ou indiretamente — do grande capital internacional ou multinacional. A partir daí, argumenta-se que isto acarretou a adoção de formas de organização da produção altamente intensivas em capital. Por isso, tais indústrias teriam sido incapazes de gerar novos empregos que absorvessem a população urbana que, no período, cresceu a taxas elevadas, em decorrência tanto do crescimento vegetativo da população como em conseqüência das transformações sofridas pelo setor agropecuário. Estas transformações se deram quer por razões de modernização das técnicas produtivas, por mudanças de cultivo e de atividade (substituição da agricultura pela pecuária), por transformações nas relações de trabalho ou, finalmente, pela estagnação e pressão demográfica em algumas áreas, que redundaram em crescente migração do campo para a cidade, inchando o sistema urbano.

A evolução do sistema urbano, por sua vez, de acordo com o mesmo argumento, caracterizou-se por crescente concentração das atividades urbano-industriais modernas em poucos centros, cujo porte se avolumou ao longo do período, nos quais se foram concentrando grandes contingentes populacionais de migrantes pobres e marginalizados, pela sua não absorção nos mercados de trabalho dos setores mais dinâmicos.

Uma consequiência do processo recente de desenvolvimento assim caracterizado teria sido o escasso dinamismo do setor industrial em gerar empregos; outra teria sido a acentuação do grau de concentração da população urbana, elevando-se o grau de primazia existente no sistema urbano,

E, é a partir deste tipo de argumento e de suas conseqüências que são derivadas políticas que privilegiam o desenvolvimento industrial com base em tecnologias intensivas em trabalho e que defendem a valorização das cidades de porte médio. Por isso, e para começar a desfazer eventuais equívocos de interpretação com respeito às raízes da persistência e da difusão de elevados níveis de pobreza no país, após processo tão vigoroso de crescimento econômico, é necessário analisar, do ponto de vista empírico, a evolução do processo de urbanização nos últimos anos, a conformação do sistema urbano daí resultante e a dinâmica da geração do emprego a ele associada. A isto me dedico, respectivamente, nas partes II e III deste trabalho.

\section{As tendências do processo de urbanização (1950-1980)}

Muito embora por volta de 1950 o Brasil já tivesse atingido um patamar de urbanização que gerava problemas urbanos e dava lugar a movimentos em tomo de reivindicações urbanas (água, luz, transporte, habitação e carestia da vida urbana), pelo menos do ponto de vista ecológico-demográfico o país ainda era "essencialmente agrícola". Como mostram os dados da Tabela 2,4/5 da população viviam em áreas rurais ou em vilas, povoados e pequenas cidades de menos de 20000 habitantes. Mesmo na região industrialmente mais 
desenvolvida do país, apenas 30,4 por cento da população viviam em cidades de mais de 20000 habitantes.

Entre 1950 e 1980 o processo de urbanização acelerou-se de tal forma que, mesmo adotando-se uma definição bastante restritiva de população urbana, ${ }^{4}$ em 1980, 50,6 por cento da população brasileira viviam em cidades de mais de 20000 habitantes. Enquanto o total da população brasileira, entre 1950 e 1980, cresceu a uma taxa anual de 2,86 por cento, a população urbana (definida pelos critérios da Tabela 5) cresceu a uma taxa anual de 5,64 por cento.

Tabela 2 ANA DA POPULAČ̃o (1950-1980)

\begin{tabular}{|c|c|c|c|c|c|c|}
\hline \multirow[t]{2}{*}{ Regizes } & \multicolumn{2}{|c|}{$\begin{array}{l}\text { Areas rurais, vilas } \\
\text { cidades de } 20000 \text { hab } \\
\text { (ou menores) }\end{array}$} & \multicolumn{2}{|c|}{$\begin{array}{l}\text { Cidades de } \\
\text { mais de } 200000 \text { hab }\end{array}$} & \multicolumn{2}{|c|}{ Totais } \\
\hline & 1950 & 1980 & 1950 & 1980 & 1950 & 1980 \\
\hline Norte & 1529825 & 3666291 & 314830 & 2362270 & 1844655 & 6028561 \\
\hline Nordeste & 15942538 & 23879851 & 2030294 & 11539305 & 17972832 & 35419156 \\
\hline Centro-Oeste & 1641641 & 5088145 & 95424 & 2654058 & 1737065 & 7742203 \\
\hline Sudeste & 15689863 & 16180086 & 6851413 & 36400441 & 22541376 & 52580527 \\
\hline Sul & 6798144 & 11082534 & 1042726 & 8297592 & 7840870 & 19380126 \\
\hline Brasil & 41002011 & 59896907 & 10334687 & 61253666 & 51936698 & 121150573 \\
\hline
\end{tabular}

FONTE: FIBGE, Censo Demográfico de 1950,e Sinopse Preliminar do Censo Demograficico de 1980.

Mesmo adotando um critério exigente para a definição de cidade, (considerar como cidades apenas os municípios com mais de 20000 habitantes em sua sede), entre 1950 e 1980 o número de

4 Nesta definição restrita de população urbana, entende-se como tal as pessoas vivendo na sede urbana dos municípios, e considera-se como cidades as sedes municipais com mais de 20000 habitantes. cidades passou de 96 para 482. O aumento no número de cidades se concentrou na região Sudeste (46,9 por cento do aumento), mas ocorreu com grande intensidade relativa em todas as regiões, como mostram os dados da Tabela 3. Para o país como um todo, como indicam os dados da Tabela 4, o ritmo do aumento no número de cidades, embora elevado em todas as décadas aqui analisadas, foi caindo, ligeiramente, ao longo do período.

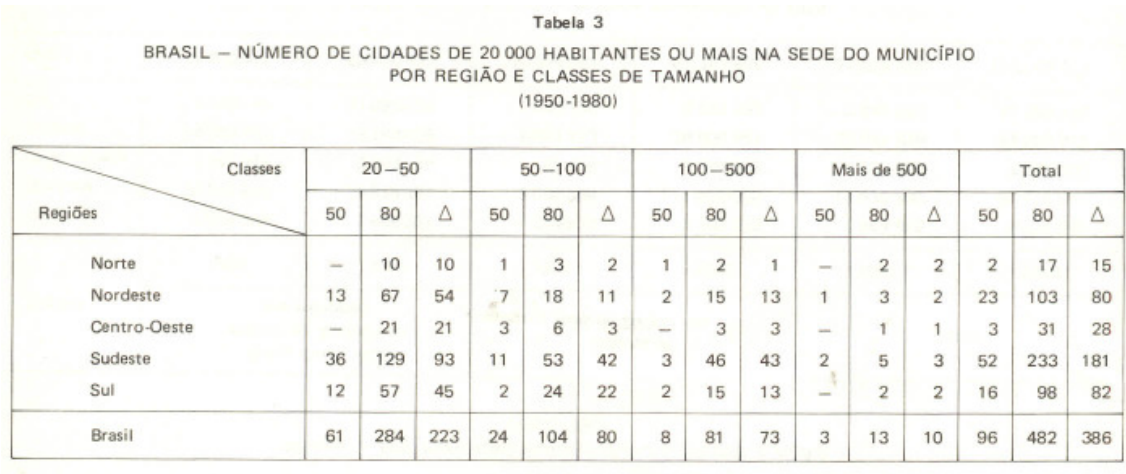

FONTE: FIBGE, Censos Demograficicos de 1950, 1960,1970 e Tabulacöes Avancadas do Censo Demorrático de 1980

Vejamos, agora, as tendências da urbanização do ponto de vista do ritmo de crescimento da população urbana nas diversas regiões do país e nas diferentes classes de tamanho urbano. Os dados de síntese aparecem nas Tabelas 5 e 6.

Cabe notar, em primeiro lugar, que o ritmo de crescimento da população urbana no Brasil, embora elevado em todo o período 19501980, foi arrefecendo de uma década para outra. A taxa de crescimento anual, para o país como um todo, passou de 6,31 por 
cento na década de 1950 para 4,83 na década de 1970. Este resultado, ainda que importante, não deve obscurecer o fato de que as taxas partem, de uma década para outra, de bases populacionais urbanas cada vez maiores, o que significa que os contingentes absolutos agregados à população urbana crescem de um subperíodo para outro. Os dados da Tabela 5 mostram, também, que o comportamento das taxas variou de uma região para outra.

$$
\text { Tabela } 4
$$

BRASIL - NUMERO DE CIDADES DE 20000 HABITANTES OU MAIS (1950-1960-1970-1980)

\begin{tabular}{|c|c|c|c|}
\hline \multirow{2}{*}{ Ano } & \multirow{2}{*}{ Número } & \multicolumn{2}{|c|}{ Aumento } \\
\cline { 3 - 4 } & & Absoluto & $\%$ \\
\hline 1950 & 96 & & \\
1960 & 172 & 76 & 79,2 \\
1970 & 300 & 128 & 74,4 \\
1980 & 482 & 182 & 60,7 \\
\hline
\end{tabular}

FONTE: Tabela 2.

Assim, na região Sudeste, a mais populosa e a mais urbanizada, a tendência das taxas foi a mesma que para o conjunto do país, caindo de 5,99 por cento na década de 50, para 4,19 por cento na década de 70 .
Tabela 5

BRASIL - TAXAS DE CRESCIMENTO DA POPULAÇÃO URBANA, EM CIDADES DE 20000 OU MAIS HABITANTES, POR REGIÕES (1950-1980)

\begin{tabular}{l|c|c|c|c|}
\hline \multirow{2}{*}{ Regiões } & \multicolumn{4}{|c|}{ Períodos } \\
\cline { 2 - 5 } & $1950-1960$ & $1960-1970$ & $1970-1980$ & $1950-1980$ \\
\hline Norte & 5,87 & 6,56 & 7,25 & 6,56 \\
Nordeste & 5,64 & 5,89 & 4,73 & 5,42 \\
Sudeste & 5,99 & 5,53 & 4,19 & 5,23 \\
Sul & 8,92 & 5,57 & 6,23 & 6,90 \\
Centro-Oeste & 9,46 & 10,86 & 8,26 & 9,52 \\
\hline Brasil & 6,31 & 5,77 & 4,83 & 5,64 \\
\hline
\end{tabular}

=ONTE: FIBGE, Censos Demográficos de 1950, 1960, 1970 e 1980

No Nordeste, segunda região mais populosa do país, conquanto relativamente pouco urbanizada em 1950 (taxa de urbanização de 11,30 por cento), a taxa anual de crescimento da população urbana acelerou-se ligeiramente na década de 1960, passando de 5,64 por cento entre 1950 e 1960 para 5,89 por cento na década seguinte, arrefecendo na década de 1970 , quando foi de 4,73 por cento. 
Tabela 6

BRASIL - TAXAS DE CRESCIMENTO DA POPULAÇÃO URBANA, EM CIDADES DE 20000 OU MAIS HABITANTES, POR CLASSES DE TAMANHO (1950-1980)

\begin{tabular}{|c|c|c|c|c|c|}
\hline \multirow{2}{*}{ Períodos } & \multicolumn{5}{|c|}{ Classes de tamanho (em mil habitantes) } \\
\cline { 2 - 6 } & $20-50$ & $50-100$ & $100-500$ & +500 & TOTAL \\
\hline $1950-1960$ & 6,21 & 4,18 & 7,55 & 6,50 & 6,31 \\
$1960-1970$ & 5,63 & 4,04 & 8,48 & 4,83 & 5,77 \\
$1970-1980$ & 4,50 & 5,86 & 5,44 & 4,24 & 4,83 \\
\hline $1950-1980$ & 5,45 & 4,69 & 7,15 & 5,19 & 5,64 \\
\hline
\end{tabular}

FONTE: FIBGE, Censos Demográficos de 1950, 1960, 1970 e 1980.

Na região Sul, que apresentava uma taxa de urbanização de 13,30 por cento em 1950 , a população urbana cresceu a taxas mais elevadas que a população urbana do país como um todo, em todas as décadas do período, particularmente entre 1950 e 1960 (8,92 por cento ao ano), ainda para 5,57 por cento anuais entre 1960 e 1970 e voltando a subir ligeiramente na década seguinte $(6,23$ por cento ao ano).

As duas outras regiões brasileiras, Norte e Centro-Oeste, menos populosas e menos urbanizadas, também cresceram a taxas elevadas. Na região Norte, as taxas-anuais de crescimento se aceleraram durante o período, passando de 5,87 por cento entre 1950 e 1960 para 7,25 por cento na década de 70. Finalmente, foi na região Centro-Oeste onde a população urbana cresceu a taxas mais elevadas, especialmente entre 1960 e 1970, fruto, entre outras razões, da baixa taxa de urbanização no começo do período e do impacto de Brasília.

A conclusão mais importante a que se pode chegar analisando a evolução regional do crescimento urbano entre 1950 e 1980 é que diminuíram as diferenças entre as regiões com relação à taxa de urbanização (população urbana/população total), o que qualifica a hipótese de concentração urbana, apreciada a partir da tendência das taxas de crescimento a nível regional. Esta qualificação se reforça quando analisamos as taxas de crescimento por classes de tamanho urbano, para o Brasil como um todo.

Em primeiro lugar, tomando o período 1950-1980, observa-se que a taxa de crescimento anual da população urbana foi mais elevada na classe de 100000 a 500000 habitantes (7,15 por cento) equivalendo à taxa média do conjunto da população urbana na classe de 20000 a 50000 habitantes (5,45 por cento). A população do conjunto de cidades na classe de 500000 habitantes ou mais, por seu turno, cresceu a urna taxa inferior à da população urbana como um todo $(5,19$ por cento contra 5,64 por cento, respectivamente).

Em segundo lugar, analisando o comportamento das taxas de crescimento por décadas, observamos que estas arrefecem regularmente na classe das maiores cidades. Na década de 70 foi a população urbana das cidades de entre 50000 e 500000 habitantes que cresceu a taxa superior ã média brasileira, para a década.

É de se notar também, e para concluir, que se observa uma tendência à homogeneização das taxas de crescimento por classes de 
tamanho urbano ao longo dos trinta anos, como se pode ver pelas taxas que ocorreram na década de 70. Tudo isso indica uma difusão do processo de urbanização tanto pelo território como por diferentes classes de tamanho urbano. A questão da concentração da população urbana brasileira, no período 1950-1980, precisa, portanto, ser melhor analisada.

Para isso, e ainda que com propósitos didáticos, é preciso distinguir entre o grau de urbanização ou de concentração da população em áreas urbanas (medida pela taxa de urbanização) e a concentração da população urbana em algumas cidades ou regiões (medida por índices de primazia e concentração urbanas).

\section{Grau de urbanização, tamanho urbano e concentração da população urbana}

\section{Grau de urbanização}

A magnitude da urbanização ocorrida no Brasil entre 1950 e 1980 não pode deixar dúvida quanto à crescente concentração do conjunto da população brasileira em áreas urbanas. Na verdade, na década de 70 ocorreu, pela primeira vez na história do país, um declínio em termos absolutos da população rural, segundo a definição censitária. ${ }^{5}$ Usualmente, o grau de urbanização é medido pela taxa de

5 Para evitar confusões terminológicas, o nível de concentração da população em áreas urbanas - em oposição às áreas rurais - será referido como grau de urbanização. Goldstein, Sidney e Sly, David, 1975. urbanização (total da população urbana/total da população) ou pela razão urbano/rural de população (total da população urbana/total da população rural). Qualquer que seja a medida adotada pode haver alguma variação no grau de urbanização em função dos critérios definidores da população urbana. Para avaliar o grau de urbanização da população brasileira no período 50-80 usarei três definições diferentes de população urbana: o critério censitário, o critério de mais de 20000 habitantes vivendo em áreas urbanas do município e o critério de mais de 20000 habitantes na sede urbana do município. Na Tabela 7 aparecem as duas medidas de grau de urbanização para cada um dos critérios adotados.

Tabela 7

BRASIL - GRAU DE URBANIZAÇÃO (1950-1980)

\begin{tabular}{|c|c|c|c|c|c|c|}
\hline \multirow[b]{2}{*}{ Anos } & \multicolumn{2}{|c|}{$\begin{array}{l}\text { Critério } \\
\text { censitário }\end{array}$} & \multicolumn{2}{|c|}{$\begin{array}{c}\text { Critério } \\
\text { cidade } \\
+20000\end{array}$} & \multicolumn{2}{|c|}{$\begin{array}{l}\text { Critério } \\
\text { sede municipal } \\
+20000\end{array}$} \\
\hline & $\mathrm{PU} / \mathrm{PT}$ & PU/PR & PU/PT & PU/PT & $\mathrm{PU} / \mathrm{PT}$ & $\mathrm{PU} / \mathrm{PT}$ \\
\hline 1950 & 36,2 & 0,57 & 21,5 & 0,35 & 21,4 & 0,34 \\
\hline 1960 & 45,1 & 0,82 & 27,0 & 0,49 & 26,9 & 0,49 \\
\hline 1970 & 56,0 & 1,27 & 36,2 & 0,82 & 33,7 & 0,76 \\
\hline 1980 & 67,7 & 2,10 & 45,7 & 1,41 & 45,1 & 1,41 \\
\hline
\end{tabular}

FONTE: FIBGE, Censos Demográficos de 1950, 1960, 1970 e 1980.

Cabe registrar que a adoção de um ou outro dos dois últimos 
critérios não conduz a grandes diferenças. ${ }^{6}$ Contudo, encontramos diferenças marcantes se usamos um deles ou o primeiro critério ${ }^{7}$. .8 Assim, a taxa de urbanização do país em 1980 pode variar entre $67,7 \%$ e $45,1 \%$ e a razão urbano/rural entre 2,10 e 1,41 em função do critério adotado. Tais diferenças não afetam apenas o orgulho nacional; podem ter implicações para a hierarquização, quando esquemática, dos problemas nacionais e afetar diferencialmente o conteúdo mais geral das políticas governamentais.

Apesar destas diferenças, não existe polêmica maior a respeito do grau de urbanização da população brasileira no período que estou analisando. A discussão mais interessante e difícil diz respeito ao grau de concentração da população urbana, ou seja, em que medida a urbanização ocorre através do crescimento equilibrado das cidades de vários tamanhos ou se dá de forma concentrada em cidades de alguma região ou de alguma classe de tamanho.

A conceituação do que venha a ser "concentração", infelizmente, sofre de ambigüidade e os procedimentos de mensuração, além de diversos, apresentam problemas importantes de

6 Por razões de comparabilidade intercensitária usarei o terceiro indicador, mais exigente, salvo indicações em contrário.

7 A razão urbano/rural pode não ser inferior a 1,0 quando a taxa de urbanização, usando-se o critério de mais de 20000 habitantes, é inferior a $50 \%$, porque a população vivendo em cidades menores não é contada como rural.

8 A razão urbano/rural pode não ser inferior a 1,0 quando a taxa de urbanização, usando-se o critério de mais de 20000 habitantes, é inferior a $50 \%$, porque a população vivendo em cidades menores não é contada como rural. validade. $^{9}$ Convém, portanto, separar diferentes sentidos da concentração da população urbana.

\section{O tamanho urbano}

Abstratamente, seria possível conceber um processo de urbanização, a partir de um certo ponto, que não implicasse crescimento do tamanho absoluto de qualquer localidade urbana já existente. Bastaria que os acréscimos de população urbana ocorressem em novas localidades. Semelhante fenômeno é, entretanto, quase inconcebível, dada a natureza mesma do processo de urbanização, que acarreta concentração de funções em alguns pontos $^{10}$. Por isso, é razoável dizer que todo processo empírico de urbanização redunda no aumento.do tamanho absoluto das cidades, havendo portanto concentração de população em localidades urbanas específicas $^{11}$.

O que causa impacto, deste ponto de vista, é que no processo brasileiro de urbanização algumas cidades atingiram tamanhos absolutos de considerável magnitude. Em 1980 havia no país trinta aglomerações $^{12}$ urbanas de mais de 250000 habitantes e, como

9 Ver, entre outros, Goldstein e Sly, op. cit., pp. 59-72.

$10 \mathrm{Tal}$ como apontam as diversas versões da teoria do lugar central.

11 A questão mais geral da concentração dependerá então de em quantas e em que localidades do sistema urbano está-se dando este acúmulo de população.

12 Considerei, nesta tabela, além da população urbana das áreas metropolitanas e de cidades isoladas de mais de 250000 habitantes, a 
mostram os dados da Tabela 8 , destas aglomerações nove possuíam mais de um milhão de habitantes.

Nestas trinta aglomerações viviam em 1980 mais de 42 milhões de pessoas, representando $35 \%$ da população recenseada em 1980, 51,7\% da população urbana definida pelo critério censitário e $76,6 \%$ da população vivendo em cidades de mais de 20 mil habitantes! Nada mais natural, portanto, que concluir - com base nestes indicadores - pela concentração crescente da população urbana. E, dada a evolução dos tamanhos absolutos das populações urbanas das grandes metrópoles nacionais (Rio e São Paulo), inferir que o grau de primazia urbana vem aumentando no sistema urbano brasileiro $^{13}$.
Tabela 8

BRASIL - POPULAÇÃO NAS AGLOMERAÇÕES URBANAS DE MAIS DE 250000 HABITANTES

$$
\text { (1980) }
$$

\begin{tabular}{|l|r|}
\hline Aglomeração & População \\
\hline São Paulo & 12183139 \\
Rio de Janeiro & 8826190 \\
Belo Horizonte & 2477060 \\
Porto Alegre & 2164032 \\
Recife & 2132852 \\
Salvador & 1701505 \\
Fortaleza & 1502855 \\
Curitiba & 1327751 \\
Brasília & 1177393 \\
Santos & 903294 \\
Goiânia & 895004 \\
Campinas & 832819 \\
Manaus & 613068 \\
Vitória & 595367 \\
Maceió & 449506 \\
São José dos Campos & 429998 \\
Natal & 416906 \\
Jouão Pessoa & 403951 \\
Pelótas-Rio Grande & 342204 \\
Terezina & 339264 \\
Jundiaí & 319812 \\
Barra Mansa-Volta Redonda & 316448 \\
Sorocaba-Votorantin & 316405 \\
Ribeirão Preto & 308229 \\
Juiz de Fora & 301997 \\
Aracaju & 293619 \\
Campo Grande & 283684 \\
Ipatinga-Coronel Fabriciano-Timóteo & 269225 \\
Londrina & 267102 \\
São Luís & 266970 \\
\hline TOTAL & 42374030 \\
\hline
\end{tabular}

FONTE: FIBGE, Sinopse Preliminar do Censo Demográfico de 1980 e Indicadores Sociais para Áreas Urbanas, 1976. população de certo número de regiões urbanas definidas pelo IBGE, em 1970, como conurbações reais ou embrionárias. Ver FIBGE, Indicadores, Socais, para Área, Urbana" 1976.

13 A literatura sobre o tema é abundante, desde a formulação clássica de Jefferson, 1939. Para uma discussão mais detalhada dos casos latinoamericanos, em geral, e brasileiro, em particular, até o final da década de 70, veja-se, respectivamente, Browning, 1972 e Faria, 1976.

Sociois para Areas Urbanas, 1976.




\section{O grau de primazia no sistema urbano brasileiro - 1950-1980}

No Brasil, a afirmação de que o sistema urbano apresentaria níveis crescentes de primazia urbana esteve associada, durante a década de 1960, às afirmações sobre o caráter dependente do desenvolvimento nacional e suas conseqüências para o fenômeno da marginalidade urbana. Durante a década de 1970, entretanto, surgiram diversas críticas a esta associação, à medida que os dados sobre o crescimento das cidades lançavam dúvidas sobre o aumento no grau de primazia. ${ }^{14}$ Por isso mesmo, parece importante começar a avaliar a questão da concentração relativa da população urbana pela evolução do grau de primazia.

Usarei, para este propósito, o índice de primazia desenvolvido a partir da equação de rank-size ${ }^{15} \mathrm{e}$, dado o número de cidades de grande porte no Brasil, optei por comparar a cidade maior com as dez cidades de tamanho subseqüente. Além disso, creio ser necessário levar em conta duas características do sistema urbano brasileiro na avaliação do grau de primazia. Em primeiro lugar, a existência de bipolaridade metropolitana, uma vez que tanto São Paulo quanto o Rio de Janeiro desempenham funções de metrópole nacional e, em segundo lugar, o fenômeno da crescente aglomeração de municípios

14 Ver Kowarick, 1976; Faria, 1976a; Merrick e Graham, 1981.

15 Ver Goldstein e Sly, op. cit., pp. 63-65. em áreas conturbadas, principalmente nas regiões metropolitanas. ${ }^{16}$ $\mathrm{Na}$ Tabela 9 apresento quatro índices de primazia. O primeiro mede a primazia da maior cidade com respeito às dez cidades subseqüentes (P 1/11); o segundo mede a primazia das duas maiores cidades com respeito às nove cidades subseqüientes $(\mathrm{P} 2 / 11)$; o terceiro mede o grau de primazia da maior área metropolitana com respeito às dez áreas metropolitanas ou cidades subseqüentes e o quarto mede o grau de primazia das duas maiores áreas metropolitanas com respeito às nove áreas urbanas de tamanho. subseqüente.

Tabela 9

BRASIL - INDICES DE PRIMAZIA URBANA $(1950-1980)$

\begin{tabular}{|c|c|c|c|c|}
\hline \multirow{2}{*}{ Anos } & \multicolumn{2}{|c|}{ Cidades } & \multicolumn{2}{c|}{ Áreas metropolitanas } \\
\cline { 2 - 5 } & $\mathrm{P}_{1 / 11^{a}}$ & $\mathrm{P}_{2 / 11^{b}}$ & $\mathrm{P}_{1 / 11^{a}}$ & $\mathrm{P}_{2 / 11^{b}}$ \\
\hline 1950 & 0,865 & 1,305 & 1,157 & 1,885 \\
1960 & 0,875 & 1,520 & 1,007 & 1,680 \\
1970 & 0,874 & 1,137 & 1,055 & 1,661 \\
1980 & 0,973 & 1,295 & 1,494 & 1,062 \\
\hline
\end{tabular}

OBS.: (a) $\quad P_{1 / 11}=\frac{2 C_{1}}{\sum_{i=2}^{11} C_{i}}$

(b) $\quad P_{2 / 11}=\frac{C_{1}+C_{2}}{\sum_{i=3}^{11} C_{i}}$

16 As áreas metropolitanas foram definidas legalmente no final da década de 60. Para 1950 e 1960 usarei como população metropolitana a população urbana dos municípios da área mínima comparável. 
Os resultados permitem concluir, em primeiro lugar, que em termos comparativos internacionais o Brasil apresenta índices relativamente baixos de primazia urbana. A Argentina, a França, o México, o Japão e os EUA apresentavam, em 1960, índices de primazia (PI/ll cidades) de ordem de 4,10, 3,41, 3,79, 1,75 e 1,05, respectivamente, enquanto o valor do índice para o Brasil é de 1,16,1,01,1,00 e 1,49, respectivamente, para 1950, 1960, 1970 e 1980. Em segundo lugar, verifica-se que quando consideramos apenas uma cidade ou uma área metropolitana, os índices de primazia respectivos são maiores em 1980 que em 1950. Mais concretamente isto significa que a cidade de São Paulo e a área metropolitana por ela organizada tenderam a aumentar sua participação no conjunto da população urbana dos onze centros urbanos de maior porte, especialmente entre 1970 e 1980.

Em terceiro lugar, observa-se que quando levamos em conta o fenômeno da bipolaridade metropolitana, a tendência anterior se inverte. $\mathrm{O}$ índice de primazia das duas áreas metropolitanas nacionais cai de 1,885 em 1950 para 1,062 em 1980. Além disso, a queda é particularmente pronunciada na década de 70 , quando este índice cai de 1,661 em 1970 para 1,062 em $1980 .^{17}$

Os três resultados, em conjunto, permitem concluir que o grau de primazia do sistema urbano brasileiro é relativamente baixo e que,

17 O comportamento do índice de primazia das duas cidades metropolitanas centrais é mais irregular, apresentando ligeira elevação entre 1970 e 1980, mas sendo - neste último ano - inferior ao de 1950 e 1960. excetuando-se a cidade de São Paulo e sua área metropolitana, cuja participação relativa vem aumentando, o grau de primazia das duas metrópoles nacionais — tomadas conjuntamente — diminuiu entre 1950 e 1980.

Os índices de primazia, embora constituam uma primeira indicação importante do grau de concentração da população urbana, têm o inconveniente de levar em consideração apenas as cidades de maior porte.

Por isso, e em virtude do valor relativamente baixo dos índices de primazia, é conveniente avaliar a concentração da população urbana levando-se em consideração o conjunto do sistema urbano.

\section{A distribuição das cidades por classe de tamanho: a Regra do Rank-Size}

Deixando de lado, neste trabalho, as derivações substantivas que podem ser feitas sobre a relação entre a distribuição das cidades por classe de tamanho e as características do processo de desenvolvimento, ${ }^{18}$ as diversas formulações da relação (ordemtamanho) das cidades oferecem instrumentos operacionais para medir o grau de concentração da população urbana, levando-se em conta o conjunto de Cidades elo sistema urbano e não apenas algumas delas.

$\mathrm{Na}$ relação estabelecida por Zipf entre o tamanho de uma cidade e sua posição no sistema de cidades $(\mathrm{Pi}=\underline{\mathrm{P} 1})$ o coeficiente $\mathrm{q}$

18 Ver Berry e Horton, cap. 3, 1970; Berry e Kasarda, caps. 14, 16, 18 e 19 1977. 
mede o grau de concentração da população urbana: quanto mais elevado o valor de q mais concentrada estaria a população, e valores de q próximos de 1,0 indicariam a existência de um sistema urbano integrado nacionalmente e relativamente equilibrado.

Tomando a população vivendo em cidades de mais de 20000 habitantes como ponto de partida, calculei o valor de q para o sistema urbano brasileiro nos anos de 1950, 1960, 1970 e 1980. Os resultados aparecem na Tabela 10 .

Tabela 10

BRASIL - VALOR DO COEFICIENTE Q

DA EQUAÇÃO RANK-SIZE

(1950-1980)

\begin{tabular}{|c|c|}
\hline Anos & q \\
\hline 1950 & 1,0716 \\
1960 & 0,9881 \\
1970 & 0,9371 \\
1980 & 0,9420 \\
\hline
\end{tabular}

OBS.: Equação rank-size: $\quad \mathrm{p}_{\mathrm{i}}=\frac{\mathrm{p}_{1}}{\mathrm{iq}}$

Estes resultados qualificam aqueles encontrados com base nos índices de primazia. Confirmam, em primeiro lugar, o baixo grau de concentração da população urbana brasileira, já que os valores de q situam-se em torno de 1,0, com razoável estabilidade. ${ }^{19}$ Em segundo lugar, mostram que o grau de concentração diminuiu regularmente entre 1950 e 1970, como análises anteriores já apontaram ${ }^{20}$, apresentando um ligeiro aumento entre 1970 e 1980. Indicam, finalmente, que apesar deste aumento o grau de concentração da população urbana era, em 1980, ligeiramente menor que em 1950' (q igual a 0,9420 e 1,0716 , respectivamente).

Finalmente, para poder comparar a evolução do sistema brasileiro de cidades com os parâmetros teóricos estabelecidos por Berry (1961) elaboramos um gráfico com a porcentagem cumulativa de cidades por diferentes classes de tamanho em papel log-normal de probabilidades. Os dados de base aparecem na Tabela 11 e os resultados no Gráfico 1.

19 Para se ter uma idéia comparativa do grau de concentração, assinale-se que em 1960 os valores de que para Argentina! México, Canadá e EUA eram, respectivamente, 1,682, 1,551,0,990 e 0,960. 
Tabela 11

BRASIL - PORCENTAGEM ACUMULADA DO NÚMERO DE CIDADES POR CLASSE DE TAMANHO (1950-1980)

\begin{tabular}{|c|r|r|r|r}
\hline \multirow{2}{*}{$\begin{array}{c}\text { Classe de tamanho } \\
\text { (em 1 000 habitantes) }\end{array}$} & \multicolumn{4}{|c}{ Número de cidades $\%$ Acumulada } \\
\cline { 2 - 5 } & 1980 & 1970 & 1960 & 1950 \\
\hline $20-30$ & 31,9 & 35,6 & 31,8 & 37,5 \\
$30-40$ & 47,3 & 51,3 & 48,2 & 57,3 \\
$40-50$ & 59,0 & 62,1 & 60,0 & 66,7 \\
$50-\quad 60$ & 68,5 & 69,1 & 64,7 & 70,8 \\
$60-70$ & 73,5 & 72,8 & 70,6 & 77,1 \\
$70-80$ & 77,1 & 75,2 & 76,5 & 81,3 \\
$80-90$ & 78,8 & 79,2 & 79,4 & 83,3 \\
$90-100$ & 80,2 & 80,9 & 81,2 & 87,5 \\
$100-200$ & 91,0 & 92,3 & 92,9 & 90,6 \\
$200-300$ & 94,8 & 95,0 & 94,7 & 92,7 \\
$300-400$ & 96,5 & 96,3 & 96,5 & 95,8 \\
$400-500$ & 97,1 & 97,0 & 96,5 & 95,8 \\
$500-600$ & 97,5 & 98,0 & 96,5 & 96,9 \\
$600-700$ & 97,9 & 98,0 & 98,2 & 96,9 \\
$700-800$ & 98,3 & 98,0 & 98,8 & 96,9 \\
$800-900$ & 98,5 & 98,3 & 98,8 & 97,9 \\
$900-1000$ & 98,5 & 98,7 & 98,8 & 97,9 \\
$1000-2000$ & 99,6 & 99,3 & 98,8 & 97,9 \\
$2000-3000$ & 99,6 & 99,3 & 98,8 & 100,0 \\
$3000-4000$ & 99,6 & 99,7 & 100,0 & \\
$4000-5000$ & 99,6 & 100,0 & & \\
$5000-6000$ & 99,8 & & & \\
7000 e + & 100,0 & & & \\
\hline
\end{tabular}

FONTE: FIBGE, Censos Demográficos de 1950, 1960, 1970 e 1980.

Os resultados, como não poderia deixar de ser, confirmam aqueles encontrados para o parâmetro q: até 1970 a distribuição lognormal das cidades por classes de tamanho foi se movendo na direção de um sistema menos concentrado, tendo na década de 70 apresentado um ligeiro recuo. De qualquer maneira, em termos comparativos, a distribuição de cidades, em 1970, apresenta-se "mais equilibrada" ${ }^{21}$ por classe de tamanho que em 1950, aproximando-se bastante do último estágio de desenvolvimento e integração descrito pelo modelo de evolução de sistemas urbanos apresentado por Berry (1961), levando-nos à conclusão de que o processo de desenvolvimento dos últimos trinta anos não contribuiu para maior concentração da população urbana no Brasil, pelo menos à luz dos parâmetros de avaliação disponíveis.

21 A idéia de equilíbrio está associada às conclusões de Zipf sobre a integração nacional e o sistema de cidades, conclusões que, preliminarmente, questiono. 
Gráfico 1 BRASIL - SISTEMA DAS CIDADES

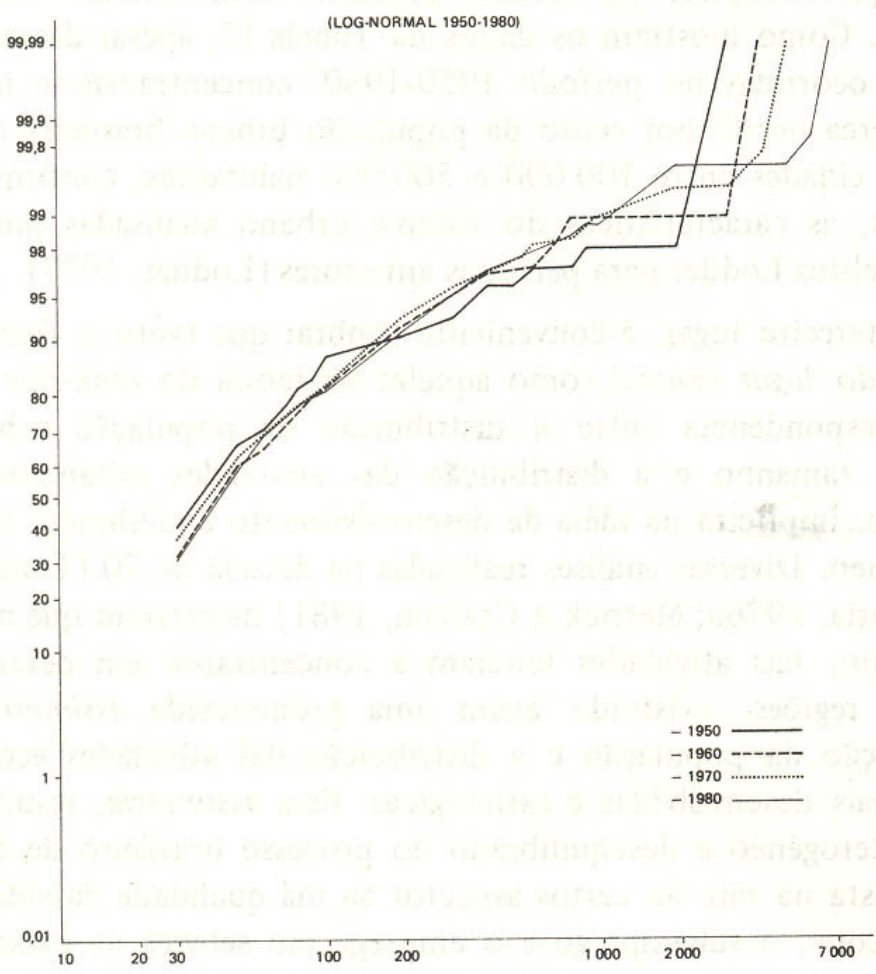

FONTE: FIBGE.

\section{Concentração geográfica da urbanização e assimetria}

Os resultados anteriores sem dúvida qualificam a questão da concentração da população urbana. Contudo, eles não devem obscurecer três outras características do sistema urbano brasileiro, importantes para a compreensão do fenômeno, em particular no que se refere à qualidade de vida.

Em primeiro lugar, o tamanho absoluto de muitas aglomerações urbanas brasileiras. Independentemente das características da distribuição de cidades por classes de tamanho, o fato de que 14 aglomerações possuíam, em 1980, mais de 500000 habitantes deve ser levado em consideração. $O$ porte dessas aglomerações acarreta, sem dúvida, um conjunto de problemas urbanos específicos, associados ao tamanho absoluto e à densidade demográfica.

Em segundo lugar, embora tendendo ao equilíbrio no que se refere à distribuição por classes de tamanho, tanto a população urbana como as cidades apresentam-se, no Brasil, bastante concentradas em termos territoriais. Como mostram os dados da Tabela 12, apesar das mudanças favoráveis ocorridas no período 1950-1980, concentravam-se na região Sudeste cerca de 60 por cento da população urbana brasileira e 56 por cento das cidades entre 100000 e 500000 habitantes, confirmando-se, para 1980, as características do sistema urbano analisadas por Milton Santos e Celsius Lodder para períodos anteriores (Lodder, 1977). 
Tabola 12
CONCENTRAÇÃO GEEGRÁIIA DA URBANIZACĀ̃o
(1950-1980)

\begin{tabular}{|c|c|c|c|c|c|c|c|c|c|c|}
\hline \multirow{2}{*}{ Regiốes } & \multicolumn{2}{|c|}{ \% Populaçāo total } & \multicolumn{2}{|c|}{ \% Populaç̧o urbana } & \multicolumn{2}{|c|}{$\begin{array}{c}\text { T. Cidades } \\
20.100000\end{array}$} & \multicolumn{2}{|c|}{$\begin{array}{c}\begin{array}{c}\% \text { Cidades } \\
100000 \cdot-500000\end{array}\end{array}$} & \multicolumn{2}{|c|}{$\begin{array}{l}\begin{array}{l}* \text { Cidades } \\
+500000\end{array} \\
+50\end{array}$} \\
\hline & 1950 & 1980 & 1950 & 1980 & 1950 & 1980 & 1950 & 1980 & 1950 & 1980 \\
\hline Norte & 3,55 & 4,98 & 3,05 & 3,86 & 1,05 & 3.37 & 12,5 & 2,44 & - & 15,38 \\
\hline Nordeste & 34,60 & 29,24 & 19,65 & 18,84 & 21,05 & 22,02 & 25,0 & 18,29 & 33,33 & 23,08 \\
\hline Sudeste & 43,40 & 43,40 & 66,30 & 59,43 & 49,47 & 47,15 & 37,5 & 56,10 & $\mid 66,67$ & 38,46 \\
\hline Săo Paulo & & & $(31,43)$ & $(29,021)$ & $(27,37)$ & $(25,65)$ & $(12,5)$ & $(32,93)$ & $(33,33)$ & $(23,08)$ \\
\hline sul & 15,10 & 16,00 & 10,09 & 13,55 & 14,74 & 20,72 & 25,0 & 18,29 & - & 15,38 \\
\hline Centro-Oeste & 3,34 & 6,39 & 0,92 & 4,33 & 13,68 & 6,73 & - & 4,88 & - & 7,69 \\
\hline Brasil & (51936 698) & (121 150 573) & (10 334687$)$ & (61 253 666) & (95) & (386) & (8) & (82) & (3) & (13) \\
\hline
\end{tabular}

FONTE: Tabelas anteriores.

Em terceiro lugar, é conveniente lembrar que tanto as formulações da teoria do lugar central como aquelas da teoria do rank-size supõem certa correspondência entre a distribuição da população urbana por classes de tamanho e a distribuição das atividades urbano-industriais estratégicas, implícita na ideia de desenvolvimento equilibrado, integrado e homogêneo. Diversas análises realizadas na década de 70 (Tolos a, 1973 e 1974; Faria, 1976a; Merrick e Graham, 1981) mostraram que no Brasil, ao contrário, tais atividades tendiam a concentrar-se em determinadas cidades e regiões, existindo assim uma pronunciada assimetria entre a distribuição da população e a distribuição das atividades econômicas urbanas mais desenvolvidas e estratégicas. Essa assimetria, resultante do caráter heterogêneo e desequilibrado do processo brasileiro de desenvolvimento, está na raiz de certos aspectos da má qualidade da vida urbana no Brasil como o subemprego e o emprego em setores de baixa produtividade. Concluímos, portanto, que nos últimos trinta anos:

1. O processo de desenvolvimento foi acompanhado por um intenso e acelerado processo de urbanização — taxa de crescimento da população urbana de 5,64 por cento ao ano - que resultou no aumento da taxa de urbanização de 36,2 por cento para 67,7 por cento ao ano, segundo o critério censitário, e de 21,5 por cento para 45,7 por cento ao ano, segundo o critério mais exigente aqui utilizado, havendo, ainda, substancial incremento no·número de cidades, que passaram de 96 para 482;

2. Esta urbanização ocorreu em todas as regiões do país, embora a taXQ3 mais altas nas regiões menos urbanizadas, e em todas as classes de tamanho urbano, ainda que a taxas mais elevadas na classe de 100000 a 500000 habitantes, havendo, entretanto, uma tendência à homogeneização das taxas de crescimento com o passar das três décadas. Isto significa que o processo de urbanizaçi10 difundiu-se pelas regiões e pelas classes de tamanho urbano;

3. Esta difusão do processo de urbanização resultou num sistema urbano caracterizado por níveis comparativamente baixos e declinantes de primazia e concentração, particularmente quando consideramos o fenômeno da bipolaridade e de metropolização;

4. Embora não tenha havido maior concentração da população urbana, continuou existindo elevada concentração regional na localização das cidades e especialmente alta concentração das atividades urbano-industriais mais dinâmicas e modernas em algumas áreas urbanas maiores do Centro-Sul do país, aumentando a 
assimetria existente entre a distribuição da população urbana (mais difusa) e a distribuição das atividades mais dinâmicas (mais concentradas).

Não se pode, portanto, atribuir à crescente concentração da população urbana papel interveniente no agravamento dos problemas de pobreza e da exclusão por todo o sistema urbano brasileiro, que adquire determinações específicas em cada região e em cidades de distinto porte.

\section{As mudanças na composição do emprego}

Outro aspecto das transformações sociais ocorridas nos últimos trinta anos são as mudanças na estrutura do emprego, aliás, elo importante na explicação da persistência ou mesmo do agravamento da pobreza e da exclusão social urbanas no Brasil contemporâneo, segundo o argumento com o qual estamos debatendo. Este elo consiste, como vimos, na alegada insuficiência dinâmica dos setores urbanos modernos - em especial do setor secundário da economia - em criar novos empregos.

Neste sentido, argumenta-se usualmente que a ocorrência desta insuficiência dinâmica em condições de pressão demográfica nas áreas urbanas acarretaria um crescimento hipertrofiado do setor de serviços e, mais particularmente, do subsetor de serviços e do pequeno comércio que, assim, crescem de modo anômalo, em bases precárias, com baixa densidade de capital, baixa rentabilidade, níveis inadequados de desenvolvimento legal e institucional, instabilidade ocupacional e baixos salários.

Mesmo havendo crescimento da indústria de transformação, alega o argumento, cada nova expansão industrial, dada a dependência financeira e tecnológica da indústria brasileira, se realiza em bases tecnológicas mais avançadas e intensivas em capital, agravando o problema da exclusão: os empregos criados pela expansão são insuficientes para compensar os empregos destruídos pelo processo de concentração e de centralização inerentes ao desenvolvimento capitalista oligopolizado, especialmente em sociedades de desenvolvimento dependente e retardatário. ${ }^{22}$

Ora, o crescimento econômico brasileiro do pós-guerra, como vimos, esteve fortemente condicionado pelo desempenho do setor industrial e em condições de aprofundamento da dependência tecnológica e financeira com relação ao grande capital estrangeiro e multinacional. Além disso, o crescimento industrial se deu através de expansões cíclicas acompanhadas, como é de se esperar, de centralização e concentração. de capitais. Como assinala Serra, no pós-guerra "a expansão do produto manufatureiro apresentou três inflexões mais agudas, as quais condicionaram variações semelhantes no crescimento do PIB. A primeira delas ocorreu a partir de 1962, depois de uma notável trajetória expansionista desde o final da guerra (9,7 por cento ao ano) e particularmente no qüinqüênio 1956-1961,

22 A literatura brasileira e latino-americana a este respeito é abundante; Para urna revisão sistemática, veja-se Faria, 1976a. 
em que a taxa de crescimento do produto industrial alcançou a média de 11,0 por cento ao ano. No qüinquiênio 1962-1967 esta taxa declinou mais de quatro vezes, atingindo a média de 2,6 por cento anuais. A segunda inflexão observou-se a partir de meados de 1967 , inaugurando a fase expansiva do milagre econômico, durante o qual o produto industrial cresceu a quase 13,0 por cento ao ano, até 1973. Em seguida, a indústria entrou numa fase de desaceleraçã'o, entre 1973 e 1980, metade daquela observada durante o 'milagre', embora não muito inferior à tendência histórica do pós-guerra e ainda razoavelmente elevada em confronto com outros países" (Serra, 1981, p.22).

A expansão, além disso, se deu, em ambos os períodos, sob a liderança da indústria de bens duráveis de consumo e de bens de capital, setores nos quais. a dependência financeira e tecnológica existiu desde o início e se agravou ao longo do tempo, com a retomada do ciclo expansivo (Serra, 1981, Mello e Belluzzo, 1977 e Conceição Tavares, 1978).

Por tudo isso, seria de se esperar que o desempenho do setor secundário - especialmente da indústria de transformação — na criação de novos empregos não fosse particularmente brilhante, ficando a modificação na estrutura ocupacional por conta do crescimento do terciário e do subsetor da construção civil, por um lado, e da contração do emprego no setor agropecuário, por outro.

Para avaliar as mudanças na composição do emprego e o desempenho dos vários setores neste particular, seria útil dispor de dados de emprego que permitissem o acompanhamento do ciclo. Caso contrário, corre-se o risco de comparar um ano de auge com outro da fase aguda de contração, chegando a inferências inadequadas, se partimos da base de que em conjunturas recessivas o emprego nos setores dinâmicos tende a cair, deixando capacidade ociosa instalada. Assim, apesar de se dispor, para o período como um todo, apenas de informação censitária, o que permite avaliar somente a variação decenal do emprego tomando como referência os anos de 1950, 1960, 1970 e 1980, na Tabela 13 apresentamos as taxas médias geométricas anuais de crescimento do produto industrial e da construção civil. Isto poderá ajudar-rios a avaliar o desempenho destes dois setores quanto à evolução do produto, nas várias décadas aqui analisadas.

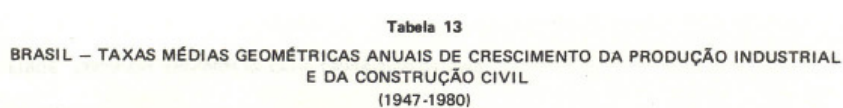

\begin{tabular}{|c|c|c|c|c|c|c|}
\hline \multirow[b]{2}{*}{ Períodos } & \multirow[b]{2}{*}{$\begin{array}{l}\text { Construỹa } \\
\text { civil }\end{array}$} & \multirow[b]{2}{*}{$\begin{array}{l}\text { Total do } \\
\text { indüstrit }\end{array}$} & \multicolumn{4}{|c|}{ Produçăo industrial } \\
\hline & & & $\begin{array}{l}\text { Bens de } \\
\text { consumo } \\
\text { durraveis }\end{array}$ & $\begin{array}{c}\text { Bens } \\
\text { de } \\
\text { capital }\end{array}$ & $\begin{array}{c}\text { Bens } \\
\text { intermediarrios }\end{array}$ & $\begin{array}{c}\text { Bens de } \\
\text { consumo } \\
\text { năo duráveis }\end{array}$ \\
\hline 1947.1955 & $5,5(\cdot)$ & $9,0(\cdot)$ & 17,1 & 11,0 & 11,8 & 6,7 \\
\hline 1955-1962 & 5,1 & 9.8 & 23,9 & 26,4 & 12,1 & 6,6 \\
\hline 1962-1967 & $(2,8)^{*}$ & 2,6 & 4,1 & $(2,6)^{\circ}$ & 5,9 & 0,0 \\
\hline 1967-1970 & 9,8 & 11,9 & 21,7 & 13,5 & 13,7 & 0,8 \\
\hline 1970-1973 & 12,0 & 13,5 & 25,5 & 22,7 & 13,2 & 9,1 \\
\hline 1973-1976 & 12,1 & 9,1 & 10,3 & 13,0 & 8.7 & 4,8 \\
\hline 1976-1980 & 6,2 & 6.4 & 8,6 & 3,4 & 8,0 & 4,1 \\
\hline 1947-1980 & $5.6(* *)$ & $8,5(\cdot)$ & 15,3 & 12,8 & 10,5 & 5,8 \\
\hline
\end{tabular}

FONTE: Serra, 1981.

(.)) Periodo 1949-1955.

(..) Perifodo 1949-1980.

Em termos apenas indicativos, ao apreciar o desempenho da 
criação de empregos em cada década convém ter presente, como se pode depreender da Tabela 13: 1) que durante a década de 1950 houve aceleração do ritmo de crescimento, sendo o ano de 1960 um ano de auge deste ciclo; 2) que na década de 1960 houve UDI primeiro momento de desaceleração seguido de um período de notável expansão e, 3) que a década de 1970 inicia-se por um período de grande crescimento e termina com uma desaceleração, embora menos acentuada que a ocorrida entre 1962 e 1967, sendo o ano de 1980 um ponto nesta fase de desaceleração.

Embora constituam aspectos do mesmo processo básico, analisarei os dados sobre a evolução do emprego setorial, com base nas informações sobre a população de dez anos e mais economicamente ativa, a partir de três ângulos: a composição da PEA por setores, o número de novos empregos criados, as taxas de crescimento e o número de pessoas empregadas nos demais setores por pessoa empregada no setor secundário da economia, esperando, com isso, melhor dimensionar o problema.

\section{Mudanças na composição do emprego da população economicamente ativa}

Os dados que permitem avaliar as mudanças na estrutura da população economicamente ativa (de dez anos e mais) aparecem na Tabela 14.

\begin{tabular}{|c|c|c|c|c|c|c|c|c|}
\hline \multicolumn{9}{|c|}{$\begin{array}{l}\text { Tabela } 14 \\
\text { BRASIL - DISTRIBUIÇÃO DA POPULAÇÃo ECONOMICAMENTE ATIVA (10 ANOS OU MAIS) POR SETORES E SUBSETORES } \\
\text { (1950-1980) }\end{array}$} \\
\hline \multirow{2}{*}{ Setores } & \multicolumn{2}{|c|}{1950} & \multicolumn{2}{|c|}{1960} & \multicolumn{2}{|c|}{1970} & \multicolumn{2}{|c|}{1980} \\
\hline & Número & \% & Número & $\%$ & Número & $\%$ & Número & $\%$ \\
\hline Primario & 10252839 & 59,9 & 12276908 & 54,0 & $\mid 13087521$ & 44,3 & 13109415 & 29,9 \\
\hline 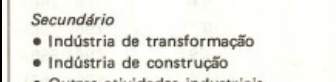 & $\begin{array}{r}2427364 \\
1608309 \\
584644\end{array}$ & $\begin{array}{r}14,2 \\
9,4 \\
3,4\end{array}$ & $\begin{array}{r}2940242 \\
1954187 \\
78247\end{array}$ & $\begin{array}{r}12,9 \\
8,6 \\
3,4\end{array}$ & $\begin{array}{l}5295417 \\
3241861 \\
1719714\end{array}$ & $\begin{array}{r}17,9 \\
11,0 \\
5,8\end{array}$ & $\begin{array}{r}10674977 \\
6858598 \\
3151094\end{array}$ & $\begin{array}{r}24,4 \\
15,7 \\
7,2\end{array}$ \\
\hline - Outras atividades industriais & 234411 & 1,4 & 204808 & 0,9 & $\begin{array}{l}333852 \\
332\end{array}$ & 1,1 & 665285 & \\
\hline Tercistrio & 4437159 & 25.9 & 7532878 & 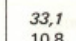 & 11174276 & 37.8 & $\begin{aligned} 20012371 \\
5\end{aligned}$ & $\begin{array}{l}45,7 \\
{ }_{13}\end{array}$ \\
\hline $\begin{array}{l}\text { - Distribuicáo (comedrcio e transportes) } \\
\text { - Prestacajo de sevvicos }\end{array}$ & $\begin{array}{l}1581233 \\
1781 \\
744\end{array}$ & $\begin{array}{r}9,2 \\
10,4\end{array}$ & $\begin{array}{l}2455615 \\
302933\end{array}$ & $\begin{array}{l}10,8 \\
13,3\end{array}$ & $\begin{array}{r}3415359 \\
3925001\end{array} \mid$ & $\begin{array}{l}11,6 \\
13,3\end{array}$ & $\begin{array}{l}5926848 \\
7089 \\
\end{array}$ & $\begin{array}{l}13,5 \\
16.2\end{array}$ \\
\hline $\begin{array}{l}\text { - Prestactio de eservics } \\
\text { - Atividades sociais e adm. pública }\end{array}$ & $\begin{array}{r}17810_{31}^{404} \\
911\end{array}$ & $\begin{array}{r}10.4 \\
5,3\end{array}$ & $\begin{array}{l}3028933 \\
1467947\end{array}$ & $\begin{array}{r}13,3 \\
6,4\end{array}$ & $\begin{array}{l}3925001 \\
2683904\end{array}$ & $\begin{array}{r}13,3 \\
9,0\end{array}$ & $\begin{array}{l}7089709 \\
4857061\end{array}$ & $\begin{array}{l}16,2 \\
11,1\end{array}$ \\
\hline $\begin{array}{l}\text { : Avtridases socials } \\
\text { OOtras atividades }\end{array}$ & $\begin{array}{l}163568 \\
1635\end{array}$ & $\begin{array}{l}1,3 \\
1,0\end{array}$ & 580383 & 2,6 & 1150012 & 2,9 & 2138753 & \\
\hline TOTAL & 17117362 & $(100,0)$ & 22750028 & $(100,0)$ & 29557224 & $(100,0)$ & 43796763 & $(100,0)$ \\
\hline
\end{tabular}

A mudança quantitativamente mais marcante reside, sem dúvida, no decréscimo substancial no percentual de pessoas empregadas no setor primário: essa queda é relativamente pequena na década de 50, quando a contribuição do setor primário para a PEA cai de 59,9 por cento em 1950 para 54,0 por cento em 1960; a queda aumenta na década de 60, passando para 44,3 por cento em 1970; acentua-se na década de 1970, quando sua participação cai quase quinze pontos percentuais, atingindo 29,9 por cento em 1980.

As mudanças na contribuição do setor secundário são também importantes. A contribuição do setor de construção civil mais que dobra entre 1950 e 1980, passando de 3,4 por cento para 7,2 por cento; a da indústria de transformação passa de 9,4 por cento para 15,7 por cento, permanecendo relativamente estável a contribuição relativa das outras atividades industriais para o total da PEA. Note-se, entretanto, que o incremento destas contribuições ocorre a partir de 
1960, tendo mesmo havido, entre 1950 e 1960, um recuo, embora modesto, da contribuição da indústria de transformação. Observando o comportamento do conjunto do setor secundário no período 19501980, destacam-se a ligeira queda na sua contribuição entre 1950 e 1960 e o avanço de mais de dez pontos percentuais entre 1960 e 1980.

Finalmente, a contribuição do setor terciário aumenta de forma relativamente regular ao longo do período, passando de 25,9 por cento em 1950 para 33,1 por cento em 1960, atingindo 37,8 por cento em 1970 e contribuindo com 45,7 por cento para a PEA total no final do período. Destaque-se com relação ao terciário, por um lado, o aumento da 'contribuição das atividades sociais e da administração pública para o emprego, que dobra no período (5,3 por cento em 1950 e 11,1 por cento em 1980) e, por outro, o crescimento da contribuição da rubrica "outras atividades", que passa de 1,0 por cento para 4,9 por cento, embora seja difícil avaliar o significado qualitativo desta rubrica, que engloba atividades mal especificadas, atividades ligadas ao setor financeiro e até mesmo as pessoas que procuram trabalho pela primeira vez, nó caso dos censos de 1970 e 1980.

Em trinta anos, portanto, passa-se de uma PEA predominantemente rural para uma PEA predominantemente urbana e, na qual, a contribuição do setor secundário representa quase uma quarta parte do emprego, havendo, em 1980, quase 7 milhões de pessoas empregadas na indústria de transformação $(15,7$ por cento do total da PEA).

Tratemos agora de analisar a contribuição dos diversos setores e subsetores para os novos empregos criados em cada década do período.

\section{A criação de novos empregos}

A população de dez anos e mais, entre 1950 e 1980, foi acrescida de mais de 50 milhões de pessoas, população superior a muitos países da Europa, passando de 36557990 para 88149988 pessoas. Neste período foram criados quase 27 milhões de novos empregos, pois a PEA passou de 17117362 para 43796763 pessoas, como se pode verificar pelos dados da Tabela 15.

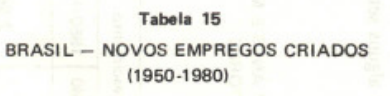

\begin{tabular}{|c|c|c|c|c|c|c|c|c|}
\hline \multirow{2}{*}{ Setores e subsetores } & \multicolumn{2}{|c|}{ 1950-1960 } & \multicolumn{2}{|c|}{$1960-1970$} & \multicolumn{2}{|c|}{ 1970-1980 } & \multicolumn{2}{|c|}{ 1950-1980 } \\
\hline & Número & \% & Número & \% & Número & \% & Número & \% \\
\hline Primário & 2024069 & 35,9 & 810613 & 11,9 & 21894 & 0.2 & 2856576 & 10,7 \\
\hline Secundärio & 512878 & 9,1 & 2355185 & 34,6 & 5379550 & 37,8 & 8247613 & 30,9 \\
\hline Indüstria de transformação & 345878 & 6,1 & 1287674 & 18,9 & 3616737 & 25,4 & 5250289 & 19,7 \\
\hline $\begin{array}{l}\text { Indüstria de construçä } \\
\text { Outras atividades industriais }\end{array}$ & 196603 & $\begin{array}{r}3,5 \\
-05\end{array}$ & 938467 & 13,8 & 1431380 & 10,1 & 2566450 & 9,6 \\
\hline Outras atividades industriais & -29603 & $-0,5$ & 129044 & 1,9 & 331433 & 2,3 & 430874 & 1,6 \\
\hline Terciarrio & 3095719 & 55,0 & 3641398 & 53.5 & 8838095 & 62,0 & $\begin{array}{r}15575212 \\
4345615\end{array}$ & 58,4 \\
\hline Distributivos & 874382 & 15,5 & 959744 & 14,1 & 2511489 & 17,6 & $\begin{array}{r}4345615 \\
530868\end{array}$ & 16,3 \\
\hline Pessoais & 1247892 & 22,2 & $\begin{array}{r}896068 \\
\end{array}$ & 13,2 & 3164708 & 22,2 & $\begin{array}{r}5308668 \\
304744\end{array}$ & 19,9 \\
\hline $\begin{array}{l}\text { Sociais } \\
\text { Outros }\end{array}$ & $\begin{array}{r}556630 \\
416815\end{array}$ & $\begin{array}{l}9,9 \\
7,4\end{array}$ & $\begin{array}{r}1215957 \\
569629\end{array}$ & $\begin{array}{r}17,9 \\
8,3\end{array}$ & $\begin{array}{r}2173157 \\
988741\end{array}$ & $\begin{array}{r}15,3 \\
6,9\end{array}$ & $\begin{array}{l}3945744 \\
1975185\end{array}$ & $\begin{array}{r}14,8 \\
7,4\end{array}$ \\
\hline TOTAL & 5632666 & $(100,0)$ & 6807196 & $(100,0)$ & 14239539 & $(100,0)$ & 26679401 & $(100,0)$ \\
\hline
\end{tabular}

FONTE: Tabela 14.

Com relação à contribuição dos vários setores para a criação de novos empregos destaque-se, em primeiro lugar, o papel 
modestíssimo do setor primário, que criou apenas 2,8 milhões de novos empregos no período, contribuindo com um pouco mais de 10 por cento para o total de empregos criados. Assinale-se, ainda, que mais de 70 por cento destes novos empregos foram criados na década de 1950; entre 1970 e 1980 foram criados apenas 22 mil novos empregos no setor primário. Este resultado, entretanto, não deve obscurecer outras transformações importantes no emprego do setor agropecuário, como mostra o texto de Sorj incluído nesta coletânea. A contribuição do setor secundário foi importante: 8247613 novos empregos foram criados neste período, sendo que mais de 5,2 milhões na indústria de transformação e pouco mais de 2,5 milhões no setor da construção civil. O secundário, no seu conjunto, contribuiu com mais de 30 por cento para a criação de novos empregos (30,9 por cento). Registre-se, além disso, o desempenho bastante modesto do setor na década de 1950: do total de empregos criados no período, 93,8 por cento o foram nas duas últimas décadas. A contribuição da indústria de transformação para a criação de novos empregos foi aumentando com o passar das três décadas aqui paralisadas: esta contribuição passou de 6,1 por cento, entre 1950 e 1960, para 18,9 por cento entre 1960 e 1970, atingindo 25,4 por cento 11/1 década de 1980. Estes resultados não deixam de ser surpreendentes, especialmente se considerarmos que para a última década estamos comparando o ano de auge do "milagre" (1970) com um ano de baixa cíclica (1980), quando se registrou incremento até mesmo do desemprego industrial aberto. Também foi importante a contribuição da construção civil — quase 10 por cento do total de novos empregos criados no período 1950-1980 - embora esta tenha sido mais acentuada, em termos relativos, na década de 1960.

Finalmente, cabe registrar O papel do setor terciário na criação de novos empregos, não só pela magnitude de sua contribuição superior a 50 por cento em todas as décadas — como também por sua regularidade, especialmente no que se refere aos serviços distributivos (comércio, transporte e comunicações) e ao resíduo heterogêneo denominado "outras atividades". Os serviços pessoais, por seu turno, apresentaram comportamento mais cíclico, contribuindo com cerca de 22,2 por cento nas décadas do começo e do fim do período, caindo esta contribuição para 13,2 por cento na década de 1960. Esta variação pode apontar para o crescimento hipertrofiado do terciário a que se refere a hipótese que temos como referência de fundo TABELA15. Apenas com estes dados, entretanto, é impossível avaliar este fenômeno. A expansão dos serviços ditos sociais (atividades sociais, administração, Forças Armadas etc.), por seu turno, foi bastante importante durante todo o período, especialmente nas duas últimas décadas. À expansão destes serviços, contudo, nio se pode atribuir caráter excludente, já que tais setores se caracterizam, em geral, por maior estabilidade, adequada proteção legal e solidez institucional.

\section{Taxas de crescimento e relações inter-setoriais de emprego}

Para concluir o exame do desempenho da economia no 
período, no que se refere ao crescimento do emprego, cabe analisar, comparativamente, o ritmo de crescimento do emprego dos vários setores em comparação com aqueles da população total e urbana, bem como as relações intersetoriais de emprego. Na Tabela 16 apresento as taxas de alguns setorespecíficos e as da população e na Tabela 17 as taxas de crescimento em cada uma das décadas e no período 1950-1980.

Tabela 16

TAXAS DE CRESCIMENTO DA POPULACÃO TOTAL, DE DEZ ANOS E MAIS, DA POPULAÇÃO URBANA E DO EMPREGO NOS SETORES SECUNDÁRIO E TERCIÁRIO (1950-1980)

\begin{tabular}{|l|c|c|c|c|}
\hline \multirow{2}{*}{ Setores } & \multicolumn{4}{|c|}{ Taxas geométricas anuais de crescimento } \\
\cline { 2 - 5 } & $1950-1960$ & $1960-1970$ & $1970-1980$ & $1950-1980$ \\
\hline População & & & & \\
Total & & & & 2,86 \\
De dez anos e mais & 2,94 & 3,04 & 2,96 & 2,98 \\
Urbana & 6,31 & 5,77 & 4,83 & 5,64 \\
Emprego & & & & \\
Total do emprego & 2,89 & 2,65 & 4,01 & 3,18 \\
Secundário & 1,93 & 6,06 & 7,26 & 5,06 \\
Ind. de transformação & 1,98 & 5,19 & 7,78 & 4,95 \\
Terciário & 5,43 & 4,02 & 6,00 & 5,15 \\
Serviços pessoais & 5,45 & 2,62 & 6,09 & 4,71 \\
Serviços sociais & 4,88 & 6,22 & 6,11 & 5,74 \\
Total do emprego urbano & 4,31 & 4,63 & 6,42 & 5,12 \\
\hline
\end{tabular}

FONTE: FIBGE, Censos Demográficos de 1950, 1960, 1970 e 1980.
Tabela 17

BRASIL - TAXAS DE CRESCIMENTO DO EMPREGO POR SETORES (1950-1980)

\begin{tabular}{|l|r|c|c|c|}
\hline \multicolumn{1}{|c|}{ Setores } & $1950-1960$ & $1960-1970$ & $1970-1980$ & $1950-1980$ \\
\hline Primário & 1,82 & 0,64 & 0,02 & 0,82 \\
Secundário & 1,93 & 6,06 & 7,26 & 5,06 \\
Ind. de transformação & 1,98 & 5,19 & 7,78 & 4,95 \\
Construção civil & 2,94 & 8,21 & 6,24 & 5,78 \\
Outras atividades & & & & \\
industriais & $-1,34$ & 5,01 & 7,14 & 3,54 \\
Terciário & 5,43 & 4,02 & 6,00 & 5,15 \\
Serviços distributivos & 4,50 & 3,35 & 5,67 & 4,50 \\
Serviços pessoais & 5,45 & 2,62 & 6,09 & 4,71 \\
Serviços sociais & 4,88 & 6,22 & 6,11 & 5,74 \\
Outras atividades & 13,50 & 7,08 & 6,40 & 8,95 \\
\hline Total & 2,89 & 2,65 & 4,01 & 3,18 \\
\hline
\end{tabular}

Comparando-se as taxas de crescimento da população e do emprego, no período analisado, cabe destacar:

1. Para o período como um todo, a taxa de crescimento do emprego foi superior às taxas de crescimento da população total e da população de dez anos e mais;

2. Isto se deveu, fundamentalmente, ao desempenho da economia na década de 70 , pois no período anterior a taxa de crescimento do emprego foi inferior às da população total e da população de dez anos "e mais. 
3. A taxa de crescimento do emprego urbano - setores secundário e terciário - foi inferior à taxa de crescimento da população urbana para o período como um todo.

4. Entretanto, na década de 70, o emprego urbano cresceu a taxa mais elevada (6,42 por cento ao ano) que a população urbana (4,83 por cento anuais).

5. O desempenho do setor secundário, que havia sido medíocre na década de 1950, melhorou consideravelmente ao longo do penado, atingindo, na década de 1970, a taxa de 7,26 por cento ao ano, bem superior à taxa de crescimento da população urbana nesta década, como já o havia sido na década anterior, em parte em virtude do bom desempenho da construção civil nos anos 60.

6. A indústria de transformação foi aumentando sua capacidade de criar empregos ao longo do penado: cresceu apenas 1,98 por cento anual na década de 50 , passando para 5,19 por cento na década de 1960 e atingindo 7,78 por cento ao ano na década de 70 .

7. O setor terciário em conjunto e para o período como um todo cresceu à taxa de 5,15 por cento ao ano, ligeiramente superior à do setor secundário e à da indústria de transformação $(5,06$ por cento e 4,95 por cento, respectivamente). Na década de 70, entretanto, o setor terciário em seu conjunto e em cada um de seus subconjuntos cresceu a taxas inferiores às do secundário e às da indústria de transformação (5,06 por cento, respectivamente). Na década de 70, entretanto, o setor terciário em seu conjunto e em cada um de seus subconjuntos cresceu a taxas inferiores ás do secundário e às industrias de transformação.

8. No interior do terciário, o subsetor dos chamados serviços sociais cresceu a taxas mais elevadas que o conjunto do terciário e que o subsetor de serviços pessoais, executando-se a década de 1950, quando ocorreu o contrário.

Em resumo, todas estas observações permitem concluir que ao longo do período: 1) melhorou a capacidade dinâmica do setor secundário - e da indústria de transformação — na criação de empregos; 2) foi melhor o desempenho do terciário institucionalizado que o do terciário chamado "marginal". Ambos os resultados contrariam o argumento com o qual estamos debatendo.

Estas conclusões 810 reforçadas quando examinamos as relações intersetoriais de emprego, tomando o setor secundário e o subsetor da indústria de transformação como referência. Segundo a hipótese que estamos discutindo, face à insuficiência dinâmica do emprego industrial e à hipertrofia do terciário marginal, deveria aumentar durante os últimos trinta anos o número de" pessoas empregadas no setor terciário - em virtude do crescimento anômalo dos serviços pessoais e do setor distributivo marginal — por pessoa empregada no setor secundário e na indústria de transformação. Entretanto, confirmando os resultados anteriores, quando analisamos os dados da Tabela 18, onde são apresentadas as relações intersetoriais de emprego, verificamos que isto não ocorre, para o período como um todo. 
Tabela 18

BRASIL - PESSOAS EMPREGADAS EM CADA UM DOS SETORES E SUBSETORES POR PESSOA EMPREGADA NO SECUNDÁRIO (1950-1980)

\begin{tabular}{|l|l|l|l|l|}
\hline \multicolumn{1}{|c|}{ Razões } & 1950 & 1960 & 1970 & 1980 \\
\hline Primário/secundário & 4,22 & 4,18 & 2,47 & 0,95 \\
Terciário/secundário & 1,83 & 2,56 & 2,11 & 1,87 \\
Serviços distributivos/secund. & 0,65 & 0,83 & 0,64 & 0,55 \\
Serviços pessoais/secundário & 0,73 & 1,03 & 0,74 & 0,66 \\
Serviços sociais/secundário & 0,37 & 0,50 & 0,51 & 0,45 \\
Outras ocupações/secundário & 0,07 & 0,20 & 0,22 & 0,20 \\
\hline
\end{tabular}

FONTE: Tabela 14.

Assim, embora o número de pessoas empregadas no conjunto do setor terciário por pessoa empregada no setor secundário tenha aumentado bastante entre 1950 e 1960, quando esta relação passa de 1,83 para 2,56, a partir de 1960 este número começa a cair, atingindo a cifra de 2,11 em 1970 e caindo para 1,87 em 1980. Esta queda é ainda mais acentuada nas relações existentes entre o emprego nos serviços pessoais e no secundário, por um lado, e entre o emprego nos serviços distributivos e no secundário, por outro. Na verdade, em 1980 havia menos pessoas empregadas em ambos os subsetores do terciário por pessoa empregada no secundário que o número relativo a 1950. Esta relação aumentou somente no caso dos serviços sociais e no caso das outras ocupações do terciário. O primeiro destes subsetores está longe de representar o terciário marginal e, no caso do segundo, é tal sua heterogeneidade que pouco se pode concluir.

Em resumo, as principais mudanças na estrutura do emprego resultantes do desenvolvimento dos últimos trinta anos foram:

1. A importante diminuição do peso relativo ao emprego vinculado ao setor agropecuário, embora, em termos absolutos, este contingente ainda representasse, em 1980, mais de 13 milhões de pessoas;

2. O crescimento em números absolutos e em termos relativos do contingente de pessoas ligadas à indústria de transformação e à construção civil. Se tomamos este emprego como indicativo da magnitude dos segmentos do operariado urbano industrial, isto quer dizer que em trinta anos o seu número quase quintuplicou. O fato de que este tipo de emprego — particularmente o da indústria de transformação - tenha crescido de forma espacialmente concentrada tem importantes conseqüências sociais e políticas;

3. o crescimento, tanto absoluto como relativo, do emprego direta ou indiretamente ligado às funções estatais não diretamente produtivas, que também quintuplicou nestes trinta anos

4. o notável crescimento, em termos absolutos, do emprego classificado como outras atividades, que por sua heterogeneidade indicam a complexificação da estrutura ocupacional brasileira e a estreiteza da classificação trissetorial clássica, sendo importante lembrar, ainda, que neste grupo, a partir de 1970, passaram a ser incluídas pessoas desempregadas e pessoas buscando trabalho, pela primeira vez. 
Em termos do argumento com o qual estamos debatendo, infirma-se a hipótese de insuficiência dinâmica da indústria de transformação na criação de empregos. Ao contrário, ao longo das três décadas aumentou o dinamismo deste subsetor: na década de 60 ele foi substancialmente melhor que na década de 1950, e chegou a crescer a taxa mais elevada que a da população urbana na década de 70.

O rompimento de mais este elo causal-explicativo não significa, entretanto, que os fenômenos da pobreza urbana e da exclusão social desapareçam. Como veremos em seguida, estes persistiram ao cabo de trinta anos de crescimento - inclusive do emprego - e de urbanização

\section{Pobreza e exclusão social numa sociedade periférica, de consumo e de massa}

O Brasil, no curto espaço de trinta anos, tomou-se uma sociedade urbano-industrial complexa e diferenciada. Tanto a estrutura de seu sistema urbano como de suas ocupações moveram-se no sentido de maior heterogeneidade, aguçando os desequilíbrios e desigualdades. Os inegáveis ganhos no que se refere aos níveis de produtividade e riqueza a nível macroeconômico tiveram como causa e contrapartida o crescimento da oferta de bens e serviços ao consumidor, tendo a oferta de bens duráveis crescido de forma particularmente intensa.

Entretanto, segundo quase todas as análises disponíveis, isto se deu, paradoxalmente, às custas de um agravamento ou pelo menos de escassas melhorias nos níveis e nas condições de vida de diferentes segmentos da população: apesar do relativo dinamismo do emprego industrial e da difusão da urbanização persistiram acentuados níveis de desigualdade e de pobreza, como procuro mostrar nesta parte do trabalho.

\section{Achatamento dos salários e ordenados de base e pobreza absoluta}

Assim, em que pese a grande controvérsia a respeito da importância do salário mínimo na determinação da taxa de salários no conjunto da economia (Souza e Baltar, 1979), parece inegável que a evolução do salário mínimo real constitui parâmetro importante para avaliar as condições de vida de importantes segmentos da população brasileira, especialmente aqueles localizados na base da pirâmide social. E, como mostram os dados do Gráfico 2, tomando-se o salário mínimo real de 1963 como base (100), entre 1952 e 1981, este, depois de oscilar a níveis em tomo de 110 entre 1955 e 1963, caiu substancialmente entre 1963 e 1971, permanecendo em tomo de 85 durante toda a década de 70 . 


\section{Gráfico 2}

SALÁRIO MINIMO REAL MÉDIO - NÚMEROS-ÍNDICES

$(1963=100)$

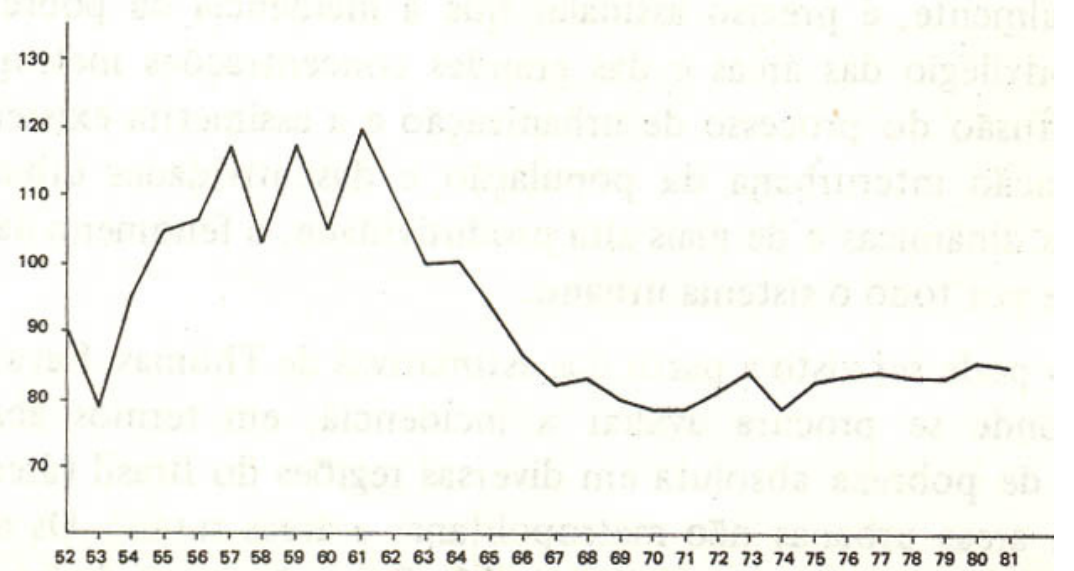

Independentemente, portanto, da controvérsia antes aludida, os dados do Gráfico 2 permitem pensar que durante a segunda metade do período aqui analisado, houve um achatamento da base salarial, pois, "desconsiderando variações nos preços relativos, a taxa de salário mínimo na economia brasileira que permitiria manter o seu valor real da segunda metade dos anos 50 deveria ser próxima do dobro do seu valor nominal atual". (Souza e Baltar, 1979, p. 644) Noutra análise, em que se levou em conta os salários urbanos medianos e variações nos preços relativos dos alimentos, Bacha chegou também a conclusão semelhante: "Apesar do aumento espetacular do PIB per capita do Brasil após a II Guerra Mundial, em termos de alimentos os salários urbanos medianos hoje não 510 maiores e provavelmente são mais baixos do que há 30 anos. Como um grupo funcional, em termos das necessidades mais básicas, parece que os trabalhadores urbanos não qualificados não se beneficiaram de modo algum do fato de a renda per capita do país ter mais que triplicado no período sob consideração", (Bacha, 1979, pp.603.604).

Dado este achatamento de salários e ordenados de base, uma parte considerável da população, independentemente do setor de inserção ocupacional, permaneceu auferindo rendimentos extremamente baixos: segundo dados da PNAD 76, 46,5 por cento da população. economicamente ativa brasileira percebiam menos de um salário mínimo, incluindo nesta cifra as pessoas sem rendimentos e desempregadas, sendo que 26,0 por cento viviam em áreas rurais.

Mesmo nas áreas urbanas do país, e tomando como unidades de referência as fam11ias, a incidência de pobreza é bastante elevada. Ainda segundo os dados da PNAD 76, 12,4 por cento das famílias urbanas brasileiras recebiam apenas um salário mínimo ou menos e 32,2 por cento ganhavam dois salários mínimos ou menos, conforme os dados da Tabela 19.

Finalmente, é preciso assinalar que a incidência da pobreza não é o triste privilégio das áreas e das grandes concentrações metropolitanas. Com a difusão do processo de urbanização e a assimetria existente entre a distribuição interurbana da população e das atividades urbano-industriais mais dinâmicas e de mais alta produtividade, o fenômeno da pobreza se difunde por todo o sistema urbano.

Isto pode ser visto a partir das estimativas de Thomas, Fava e 
Cuadra (1981), onde se procura avaliar a incidência, em termos absolutos e relativos, de pobreza absoluta em diversas regiões do Brasil (áreas metropolitanas, áreas urbanas não metropolitanas e áreas rurais). Os resultados deste exercício aparecem na Tabela 20. Segundo estes dados, fazendo estimativas do mínimo necessário abaixo do qual configura-se uma situação de pobreza absoluta - e que leva em conta variações regionais no custo de vida - cerca de 30 por cento da população brasileira,1974, achavam-se em situação de pobreza absoluta. Além do mais, para cada pobre residindo numa área metropolitana, haveria dois pobres residindo em zonas urbanas não metropolitanas e 4,57 pobres residindo numa área rural. Estas estimativas qualificam outro lugar-comum nas discussões sobre pobreza e marginalidade no Brasil, qual seja, o da concentração deste fenômeno nas áreas metropolitanas.
Tabela 20

ESTIMATIVAS DA PROPORÇÃO E DO NÜMERO DE PESSOAS CONSIDERADAS POBRES EM CADA TIPO DE LOCALIDADE (1974) - ENDEF

\begin{tabular}{|c|c|c|}
\hline \multirow{2}{*}{ Tipo de localidade } & \multicolumn{2}{|c|}{$\begin{array}{c}\text { Pessoas consideradas abaixo } \\
\text { da linha de pobreza } \\
\text { (estimativa média) }\end{array}$} \\
\hline & $\%$ & $\begin{array}{l}\text { Número } \\
(1.000)\end{array}$ \\
\hline Áreas Metropolitanas e Distrito Federal & & \\
\hline São Paulo & 6 & 498,7 \\
\hline Rio de janeiro & 8 & 570,9 \\
\hline Porto Alegre & 6 & 95,5 \\
\hline Belo Horizonte & 14 & 256,9 \\
\hline Curitiba & 13 & 105,6 \\
\hline Salvador & 36 & 444,6 \\
\hline Recife & 41 & 785,2 \\
\hline Fortaleza & 47 & 502,5 \\
\hline Belém & 9 & 67,0 \\
\hline Brasília & 13 & 87,8 \\
\hline \multicolumn{3}{|l|}{ Áreas Urbanas Não Metropolitanas } \\
\hline São Paulo & 11 & 777,2 \\
\hline Rio de Janeiro & 14 & 146,3 \\
\hline Minas Gerais/Espírito Santo & 22 & 1137,4 \\
\hline Paraná/Santa Catarina/Rio Grande do Sul & 14 & 813,4 \\
\hline Nordeste & 50 & 4182,5 \\
\hline Norte e Centro-Oeste & 25 & 277,5 \\
\hline \multicolumn{3}{|l|}{ Brasil Urbano } \\
\hline - Áreas Metropolitanas e Distrito Federal & 13 & 3414,7 \\
\hline - Áreas Urbanas Não Metropolitanas & 26 & 7334,3 \\
\hline - Áreas Rurais & 44 & 15614,0 \\
\hline
\end{tabular}

FONTE: Thomas, Vinod; Fava, Vera Lúcia e Cuadra, E. J. S. Disparidades regionais e urbano-rurais no Brasil: sua representação em termos de renda, nutrição e pobreza, 1981, mimeo. 
É preciso, por último, considerar por um lado, que a aglomeração de pobres e marginalizados em uma área urbana densa pode acarretar piora relativa nas condições de vida, especialmente aquelas mais ligadas às deseconomias de aglomeração, como ocorre nas áreas de transporte, saneamento e habitação. Por outro lado, é preciso considerar também que a dispersão de pobres e marginalizados pelo conjunto do sistema urbano pode acarretar agravamento das condições de vida, quando estas dependem de serviços que exigem certa escala, como pode ser o caso nas áreas de saúde e educação. Convém ter presente, em todos os casos, para evitar a cristalização de preconceitos, as dificuldades de se comparar situações de pobreza em contextos sócio-culturais distintos, aprofundando o estudo da condição de pobreza em cidades de diferentes tamanhos e localizadas em diferentes contextos regionais.

\section{Abertura do leque salarial e concentração da renda}

$\mathrm{O}$ achatamento dos salários e ordenados de base constitui apenas um dos aspectos do problema que estou analisando. A industrialização retardatária, sob o comando da indústria de bens duráveis de consumo, além de gerar importantes distorções na estrutura industrial, especialmente no que se refere à indústria de bens de capital, permitiu e exigiu também a abertura do leque de salários e ordenados, bem como a concentração da renda.

A diferenciação da estrutura ocupacional e uma segmentação maior dos mercados de trabalho foram, entre outros, fatores que forneceram a base sócio-estrutural sobre a qual se assentou esta distribuição desigual da renda.

Quanto à concentração da renda, apesar das inúmeras controvérsias e dificuldades técnicas que o problema envolve, tudo leva a crer que ela tenha ocorrido ancorada no achatamento dos salários e ordenados de base, pelo menos entre 1960 e 1980, como mostram os dados da Tabela 21. Mas, ao lado disso, ocorreu também no período uma abertura do leque de salários e ordenados, como mostraram as análises de Bacha e Mata (Bacha, 1974).

Tabela 21
BRASIL - DISTRIBUIÇÃO DA RENDA
(POPULAÇÄO ECONOMICAMENTE ATIVA
(1960-1980)
\begin{tabular}{|c|r|r|r|}
\hline \multirow{3}{*}{ Percentuais } & \multicolumn{3}{|c|}{ Porcentagem da renda } \\
\cline { 2 - 4 } & 1960 & 1970 & 1980 \\
\hline $20^{-}$ & 3,9 & 3,4 & 2,8 \\
$50^{-}$ & 17,4 & 14,9 & 12,6 \\
$10^{+}$ & 39,6 & 46,7 & 50,9 \\
$5^{+}$ & 28,3 & 34,1 & 37,9 \\
$1^{+}$ & 11,9 & 14,7 & 16,9 \\
\hline
\end{tabular}

FONTE: Serra, 1981.

Foi com base nessa estruturação sócio-econômica desigualdade contraditória que se constituiu, no Brasil, um mercado não só de certa magnitude como também dinâmico mas, sobretudo, um mercado 
altamente segmentado. Criou-se, em outras palavras, uma peculiar sociedade de consumo na periferia do sistema mundial.

\section{Sociedade de consumo e de massas}

Avaliar corretamente o impacto das mudanças que tiveram lugar nos últimos trinta anos sobre a estrutura social brasileira implica considerar esta peculiar sociedade de consumo e de massas que se vai configurando no país. Deste ponto de vista, é insuficiente enfatizar a existência de um contingente de excluídos pelo seu poder de compra, pois este é apenas Um dos aspectos da inserção social destes grupos na sociedade de consumo. Outro aspecto igualmente importante se relaciona ã sociabilidade específica que esta instaura, tanto do ponto de vista da mercantilização do consumo, como do ponto de vista da inculcação de hábitos, aspirações, desejos e frustrações.

Basta assinalar que, neste período, os meios de comunicação de massa se desenvolveram de forma notável no Brasil: em 1950, salvo engano, inexistam aparelhos de TV no país; em 1980, em cada quatro domicílios urbanos três possuíam um aparelho de TV e, mesmo nas áreas rurais, em cada vinte domicílios três possuíam tal equipamento. Estes meios de comunicação difundiram pautas de consumo que vêm inculcando numa parcela considerável da população modelos de consumo de uma sociedade industrial avançada, sem a correspondente base de mercado.

Mas a penetração da sociedade de consumo não parece ter·se limitado a este nível simbólico. Outro mecanismo através do qual a sociedade de conjunto deitou raízes e se difundiu foi o crédito direto ao consumidor. Levantamentos realizados por Sabóia junto aos arquivos de uma financeira de porte médio do Rio de Janeiro indicam que do total de financiamentos concedidos, em 1971, para a compra de bens duráveis de consumo inclusive automóvel - 36,5 por cento foram concedidos a consumidores com renda inferior a dois salários mínimos e 66,5 por cento a consumidores com renda inferior a 3,5 salários mínimos (Sabóia, 1981).

O impacto desta difusão da sociedade de consumo, com base no endividamento das famílias, sem a correspondente base de mercado, aliada ao rebaixamento da base de ordenados e salários, marcada por profunda segmentação e diferenciação social, não foi ainda devidamente avaliado, quer do ponto de vista da fragmentação social que ela provoca, quer do ponto de vista das formas de organização social e de manifestação política que ela enseja.

Penso, por isso, que uma compreensão sociológica mais adequada do Brasil contemporâneo exige uma análise articulada da incidência da pobreza e da expansão da sociedade de consumo. E isto exige, por um lado, considerar a natureza cada vez mais complexa e diferenciada da sociedade brasileira, evitando as generalizações simplificadoras e, por outro, enfrentar um desafio novo: o que é uma sociedade onde, para parafrasear os teóricos de Frankfurt, existe muito circo e pouco pio? 


\section{Bibliografia}

BACHA, Edmar L., "Hierarquia e Remuneração Gerencial", Estudos Econômicos. Vol. 4 (1), 1974, pp. 142-174.

"Crescimento Econômico, Salários Urbanos e Rurais: o caso do Brasil", Pesquisa e Planejamento Econômico, vol. 5 (3), dez. 1979, pp. 585-627.

e MATA, Milton, "Emprego e Salários na Indústria de Transformação, 1949/1969", Pesquisa e Planejamento Econômico, vol. 3 (2), jul. 1973, pp. 303-340.

BELluZZO, L. C. e MELlO, J. M. C., "Reflexões sobre a Crise Atual", Revista Escrita/Ensaio, n. 2,1977.

BERRY, Brian J. L., "City Size Distribution and Economic Development", Economic Development and Cultural Change, IX, 4,jui. 1961, pp. 573-588.

e HORTON, F. E., Geografic Perspectivel on Urban System, Englewood Cliffs, Prentice Hall, 1970.

e KASARDA, J. D., Contemporary Urban Ecology, Nova Iorque, MacMillan Publishing Co., 1977.

BONELlI, R. e MALAN, P. S., "Os Limites do Possível: Notas sobre Balanço de Pagamentos e Indústria nos Anos 70", Pesquisa e Planejamento Econômico, vol. 6, (2), 1976.

BROWNING, Harley, "Primacy Variation in Latin America during the Twentieth Century", in Instituto de Estudos Peruanos (org.), Urbanización y Proceso Social en América Latina, Lima, IEP, 1972, pp. 55-78.

DRAIBE, Sonia, Rumos e Metamorfoses, Tese de Doutorado, USP, 1981.

FÁISSOL, Spiridião, "Problemas Geográficos Brasileiros: Análises Quantitativas", in Revista Brasileira de Geografia, volume especial n. 14, 1972.
FARIA, Vilmar, "Occupational Marginality, Employment and Poverty in Urban Brazil", Ph. D. Dissertation, Harvard University, 1976.

"O Sistema Urbano Brasileiro: um resumo das características e tendências recentes", Estudos CEBRAP, 18, out.-nov.-dez. 1976, pp. 91-115.

"O Processo de Urbanização no Brasil: Algumas Notas para seu Estudo e Interpretação", in Anais do Primeiro Encontro Nacional da ABEP, São Paulo, ABEP, 1978, pp. 89-110.

."Urbanização e qualidade de vida no Brasil contemporâneo", trabalho apresentado no Simpósio "A Questão Migratória no Brasil - Migrações Internas e a Ação do Estado" do CNPq, Brasília, DF dez. 1981.

FIBGE, Censos Demográficos de 1950, 1960 e 1970. Sinopse Preliminar dos Censos Demográficos de 1960 e 1980.Indicadores Sociais para as Areas Urbanas, 1976.

GOLDSTEIN, Sidney e SLY, David, The Measurement of Urbanization and Projection of Urban Population, Dolhain, Ordina Edition-IUSSP, 1975.

KOWARICK, Lucio, Capitalismo e Marginalidade na América Latina, Rio de Janeiro, Paz e Terra, 1976.

LODER, Celsius, "O Processo de Crescimento Urbano no Brasil", in Pesquisa e Planejamento Econômico, vol. 7 (2), 1977, pp. 459-484.

MARTINE, George, "Notas sobre Alguns Resultados Preliminares do Censo Demográfico de 1980", Brasília, 1981, mimeo.

MERRICK, T. W. e GRAHAM, D. H., População e Desenvolvimento Econômico no Brasil, Rio de Janeiro, Zahar, 1981.

REVISTA BRASILEIRA DE GEOGRAFIA, Vol. 1, 2, 3, 4/1972 e Vol. 2/1973.

SERRA, José, "Ciclos e Mudanças Estruturais na Economia 
Brasileira do Após Guerra". Trabalho apresentado ao Seminário sobre Políticas para el Desarrollo Latinoamericano do CECADE, México, jul. 1981.

SOUZA, Amaury, "Urban Rank-Size, Economic Growth and Political Dimension", Rio de Janeiro, 1972, mimeo.

SOUZA, P. R., Saldrios, Emprego e Pobreza, São Paulo, HUCITEC, 1980.

e BALTAR, P. E., "Salário Mínimo e Taxa de Salários no Brasil", Pesquisa e Planejamento Econômico, vol. 9 (3), dez. 1979, pp. 629-659.

TAVARES, M. C., da Substituição de Importações ao Capitalismo Financeiro, Rio de Janeiro, Zahar, 1972.

TOSOLA, Hamilton, "Macroeconomia da Urbanização Brasileira", in Pesquisa e Planejamento Econômico, vol. 3 (3), out. 1973, jui. 1974, pp. 585-643.

"Diferenciais de Produtividade Industrial e Estrutura Urbana, in Pesquisa e Planejamento Econômico, vol. 4 (2), jun. 1974, pp. 325-351.

THOMAS, Vinod; FAVA, Vera Lucia e CUADRA, E. J. S., "Disparidades regionais e urbano-rurais no Brasil: sua representação em termos de renda, nutrição e pobreza", 1981, mimeo.

\section{Processos sociais e formas de produção \\ na agricultura brasileira}

Bernardo Sorj John Wilkinson

\section{Agroindústria do centro e seu impacto na periferia ${ }^{1}$}

A partir do último pós-guerra, a divisão mundial do trabalho, que tinha nos países periféricos os grandes exportadores de matériasprimas e alimentos e, nos países centrais, os produtores de manufaturas, começa a se modificar drasticamente. A periferia no seu conjunto passa a ser importadora de alimentos, e os primeiros lugares na lista de grandes exportadores de produtos agropecuários são ocupados pelos países avançados, especialmente pelos Estados Unidos. $^{2}$

1 Neste artigo tomamos como ponto de partida os dados e argumentos apresentados em Sorj, B., 1980, pretendendo aqui ampliar a caracterização conceitual das classes e estratos sociais presentes no campo brasileiro. EVOLUÇÃO DO COMÉRCIO MUNDIAL EM CEREAIS

\begin{tabular}{|l|r|r|r|r|c|}
\hline \multicolumn{1}{|c|}{ (Em milhões de toneladas) } \\
\hline EUA & $1934-8$ & $1948-52$ & 1960 & 1970 & 1976 \\
Europa Ocidental & +5 & +23 & +39 & +56 & +94 \\
América Latina & -24 & -22 & -25 & -30 & -17 \\
Europa Leste e URSS & +9 & +1 & 0 & +4 & -3 \\
África & +5 & - & 0 & 0 & -27 \\
Ásia & +1 & 0 & -2 & -5 & -10 \\
Austrália e N. Zelândia & +2 & -6 & -17 & -37 & -47 \\
& +3 & +3 & +6 & +12 & +8 \\
\hline
\end{tabular}

2 FONTE: FAO e USDA apud Trialoque, Spring, nọ 17, 1978 
Esta transformação se processou a partir da agroindustrialização do centro. Os países avançados aumentaram seus níveis de produção e produtividade em forma acelerada através de um parque industrial e científico aplicado à agricultura, enquanto que os países periféricos viram a sua capacidade de geração de excedentes exportáveis diminuída pelo crescimento demográfico e urbano, e sua produção estagnar-se ou por vezes retroceder pelo esgotamento dos recursos. Da mesma forma, a produção para o mercado interno, em geral em mãos de produtores familiares tradicionais, cujo aumento de produção se dava mais através de uma expansão horizontal (isto é, a integração de novas terras) do que por incremento de produtividade, não foi capaz de responder às necessidades da demanda interna que, além de crescer, foi-se diversificando.

O centro, a partir da modernização técnica, aumentou sua produção, passando a ser auto-suficiente em vários produtos (como no caso da Europa) e aumentando aceleradamente seus excedentes exportáveis (EUA). A América Latina se transforma assim num importador nítido de alimentos, em particular aqueles países com menor nível de industrialização e/ou orientados particularmente para a produção de matérias-primas minerais. Esta expansão da produção nos países centrais teve na agroindústria de insumos e maquinaria agrícola seu carro-chefe. Esta tinha como tripé fundamental a indústria de tratores e maquinarias agrícolas, a indústria química (fertilizantes e pesticidas) e a produção de sementes e matrizes animais em centros avançados de pesquisa genética. Nos Estados Unidos, onde esta agroindustrialização se deu com mais força, o governo estadunidense, a partir de diversos mecanismos, passou a desenvolver políticas de controle de produção e da exportação de excedentes agrícolas que ao mesmo tempo se transformavam numa arma de política externa.

Esta situação se modifica naqueles países em condições de interiorizar os complexos agroindustriais e modernizar assim suas agriculturas. Apenas os países periféricos com avançada industrialização têm condições para tanto. A alternativa de modernização através da importação de insumos e maquinaria agrícola se choca com a limitação de divisas, as quais por sua vez devem ser usadas para outros fins, sendo que a alternativa de expansão horizontal apresenta óbvios limites físicos. Isto não significa que não tenha havido anteriormente avanços tecnológicos na agropecuária, particularmente no setor exportador. Estes avanços, porém, se deram em forma parcial por não estarem ligados à existência de um complexo agroindustrial moderno. A inexistência deste complexo, por sua vez, só pode ser entendida em relação ao nível e características do processo de industrialização que caracterizou o continente; Foi somente com a implantação das indústrias siderúrgicas e automotriz, e posteriormente, das indústrias químicas e farmacêutica, que as condições foram criadas para a geração em certos países, e particularmente no Brasil, de um complexo agroindustrial moderno. 
Este complexo agroindustrial surge no bojo de um processo industrializador liderado pela empresa internacional, de forma que o complexo agroindustrial na periferia. é parte do processo de internacionalização de capital, interiorizando na periferia as práticas produtivas e tecnológicas trazidas do centro (e muitas vezes multiplicando os vícios e efeitos negativos destas).

A geração deste complexo, porém, não é automática, e só se viabiliza na medida em que: 1) exista um potencial de demanda que justifique as grandes inversões que este setor exige; 2 ) o potencial de demanda seja efetivado através de políticas públicas (ou pela capacidade/necessidade efetiva do próprio setor agrícola de consumir estes produtos); e 3) preexista uma estrutura industrial que viabilize a instalação do complexo agroindustrial.

Onde não existiam estas condições para a modernização da agricultura latino-americana, o impacto do complexo agroindustrial do centro se deu através de duas outras formas que não implicam a geração de um complexo agroindustrial interno. Estas duas formas são as plataformas de exportação e a revolução verde. Em ambos os casos os pacotes tecnológicos ligados a certos produtos são importados no que se refere a tecnologia mais sofisticada, ${ }^{3}$ e a presença da agroindústria encontra seus próprios limites na fraca capacidade de importação e/ou consumo destas economias.

3 Por exemplo, no caso da avicultura, a importação de pintinhos de linhagens e "puras".
Dentro dos países periféricos, o Brasil, é possivelmente, hoje, o país com o parque agroindustrial mais avançado e diversificado, ${ }^{4}$ sendo desenvolvido particularmente a partir do fim da década de sessenta sob a proteção e promoção do Estado autoritário. ${ }^{5}$

\section{Os processos de transformação social}

No antigo padrão de articulação campo-cidade, a estrutura fundiária era o elo direto que reproduzia as condições de existência de uma ampla massa de trabalhadores que gerava um sobre trabalho em pobres condições técnicas e que favorecia de forma imediata o conjunto do setor industrial. No atual padrão de acumulação esta estrutura está sendo substituída por outra, onde a dinamização da geração de excedentes agrícolas é dada pelo complexo agroindustrial, tanto ao nível do processo produtivo no estabelecimento agrícola como na apropriação da produção agrícola, que passa a ser crescentemente industrializada antes de alcançar o consumidor.

Neste sentido, e sem negar a importância que ainda possuem certas formas de expansão de fronteiras e da produção gerada por produtores tradicionais, pode-se afirmar que a estrutura fundiária passa a ser sobre passada pelo complexo agroindustrial na determinação das condições de reprodução das relações sociais na

4 Isto não significa que o Brasil alcançou os países centrais. No campo da genética e particularmente o da engenharia genética, que determinarão o futuro da agricultura, o Brasil apresenta ainda um grande atraso (Ver Goodman, D., Sorj. B., e Wilkinson, J., 1982).

5 Cf. SORJ, B., op. cit. 
agricultura. O complexo agroindustrial se transforma no beneficiário principal do sobre trabalho dos produtores agrícolas, substituindo crescentemente tanto o latifundista como o capital comercial tradicional e parcialmente o próprio conjunto do capital industrial.

Este processo determina que sejam as formas de subordinação da produção agrícola ao complexo agroindustrial um dos aspectoschave para se compreender as novas formas que assumem as relações sociais na agricultura no momento atual e as condições de sua transformação.

O conceito de "diferenciação social", largamente utilizado para analisar as transformações na produção, é, ao nosso ver, insuficiente para captar os efeitos da subordinação do campo à agroindústria. Portanto, propomos um modelo analítico no qual se cruzariam a diferenciação social clássica, ou "vertical", com a diferenciação "horizontal". Por diferenciação vertical ("clássica"), entendemos o processo de proletarização ou aburguesamento e a eliminação do produtor familiar. Por diferenciação "horizontal", destacamos a separação entre empresas familiares que conseguem modernizar seus processos produtivos e aqueles que terminam numa pauperização e marginalização crescente, como produto do mesmo processo.

Em termos gráficos, teríamos a seguinte situação:

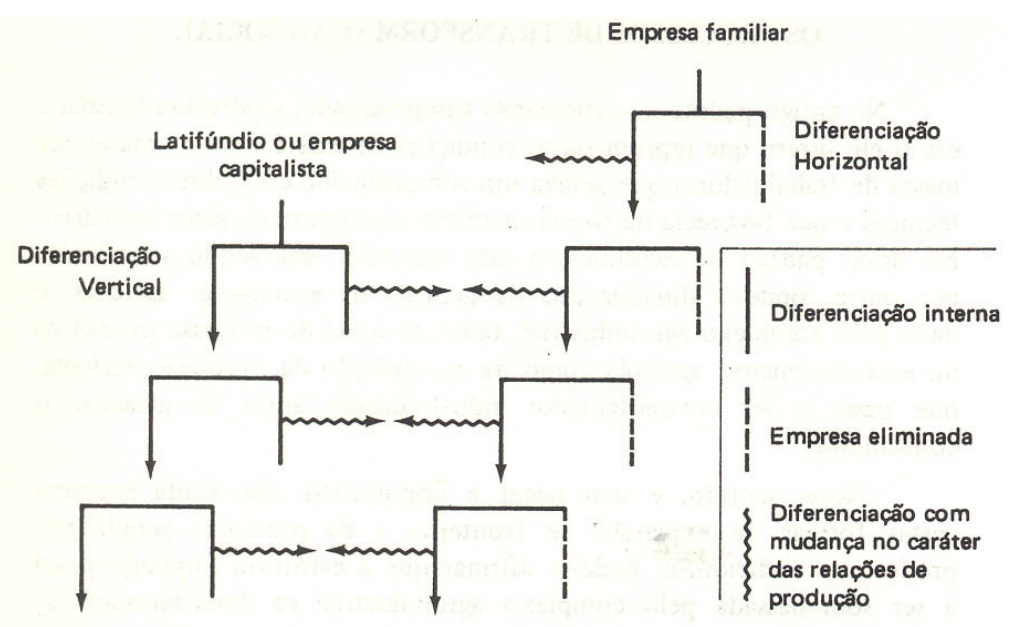

O gráfico procura descrever os seguintes processos: 1) ao nível da produção familiar uma tendência â eliminação dos produtores familiares através da expansão e/ou marginalização daqueles que não conseguem acompanhar os novos patamares tecnológicos e 2) uma diferenciação (horizontal) que implica: a) a existência de transformações dentro do conjunto de produtores familiares, sem que estas transformações conduzam à proletarização; e b) um processo ziguezagueante pelo qual empresas que anteriormente utilizavam predominantemente trabalho assalariado passam a se sustentar fundamentalmente do próprio trabalho familiar.

Este modelo é de caráter analítico-descritivo ${ }^{6}$, e sua utilidade

6 Trata-se de um modelo analítico-descritivo, na medida em que não implica a escolha de uma explicação específica das causas que lhe dão origem, como, inclusive, não hierarquiza as duas formas de diferenciação. Uma análise teórica das relações entre agricultura e capitalismo pode ser 
central é de mostrar que os processos de diferenciação social podem levar, tanto à heterogeneização da produção familiar e sua polarização em proletariado e burguesia quanto a sua manutenção, porém diferenciando-se em seu interior entre produtores familiares que permanecem viáveis e outros em processos de pauperização e eventualmente de expulsão. Ambos os processos de diferenciação, é bom insistir, geralmente aparecem em forma cruzada, de maneira que, por exemplo, os produtores familiares pauperizantes servem como força de trabalho temporária nas empresas capitalistas. Tratase, portanto, da formação de categorias sociais novas e não de estratos dentro de um continuum tradicional-moderno. Cada grupo social tem seu lugar redefinido pelo avanço da integração agroindustrial.

\section{As novas formas de produção}

No caso brasileiro podemos dizer que o processo de transformação das relações de produção da agricultura se tem dado na direção de: 1)depurar as relações de produção capitalistas nas grandes empresas agrícolas; 2) fortalecer um importante setor de produtores familiares capitalizados; 3 ) gerar uma massa de pequenos produtores pauperizados que se encontram marginalizados pela sua baixa produtividade dos grandes circuitos produtivos. Trata-se de um processo ainda fluido, onde os processos de diferenciação não estão totalmente definidos. Ainda assim pode-se assinalar que a predominância destes setores se dá de forma desigual nas diferentes regiões do país, sendo, por exemplo, predominante o terceiro no Nordeste, tanto quanto seriam os dois primeiros no Centro-Sul. .

Os dados mais recentes de alguns indicadores mostram uma aceleração desta concentração regional ao mesmo tempo como o processo de agroindustrialização penetra cada vez mais nas regiões da fronteira e nos estados do Nordeste, como mostra a Tabela 1.

Tabela 1

VARIACÃO DO NÚMERO DE TRATORES, NÚMERO DE ESTABELECIMENTOS E PESSOAL OCUPADO (1970-1980)

\begin{tabular}{|l|c|c|r|c|c|c|}
\hline Variáveis & \multicolumn{2}{|c|}{ No de tratores } & \multicolumn{2}{|c|}{ No de estabelecimentos } & \multicolumn{2}{|c|}{ Pessoal ocupado } \\
\hline Regiốes & \multicolumn{1}{c|}{$\begin{array}{c}\text { Var. } \\
\text { abs. }\end{array}$} & \multicolumn{1}{c|}{$\begin{array}{c}\text { Var. } \\
\text { rel. }\end{array}$} & $\begin{array}{c}\text { Var. } \\
\text { abs. }\end{array}$ & \multicolumn{1}{l|}{$\begin{array}{l}\text { Var. } \\
\text { rel. }\end{array}$} & \multicolumn{1}{c|}{$\begin{array}{l}\text { Var. } \\
\text { abs. }\end{array}$} & \multicolumn{1}{c|}{$\begin{array}{l}\text { Var. } \\
\text { rel. }\end{array}$} \\
\hline Norte & 4383 & 388,91 & 148287 & 56,78 & 824035 & 88,22 \\
Nordeste & 25288 & 347,31 & 243393 & 11,03 & 1721238 & 22,74 \\
Sudeste & 115453 & 139,91 & -36685 & $-3,95$ & 324158 & 8,19 \\
Sul & 165353 & 155,94 & -127494 & $-10,01$ & 193712 & 4,62 \\
$\begin{array}{l}\text { Centro- } \\
\text { Oeste }\end{array}$ & 51559 & 398,64 & 14597 & 5,77 & 401725 & 43,29 \\
\hline
\end{tabular}

FONTE: FIBGE, Censo Agropecuário, 1970 e dados preliminares do Censo de 1980.

Nas últimas três décadas se deu no Brasil um crescimento absoluto e relativo do número de produtores familiares em relação a outras categorias de trabalhadores rurais, como mostra a Tabela 2.

7 TOSCANO, G., "Composição da população ocupada no setor agrícola do Estado de São Paulo", in Política agríola e agricultura de baixa renda, Universidade Federal de Viçosa, vol. 11, 1977. 


\begin{tabular}{|c|c|c|c|c|c|c|}
\hline \multicolumn{7}{|c|}{$\begin{array}{c}\text { CATEGORIA DE PESSOAL PERMANENTE DENTRO DOS } \\
\text { ESTABELECIMENTOS AGROPECUÁRIOS } \\
(1950-1970)\end{array}$} \\
\hline \multirow[t]{2}{*}{ Categoria } & \multicolumn{3}{|c|}{ Número } & \multicolumn{3}{|c|}{ Porcentagem } \\
\hline & 1950 & 1960 & 1970 & 1950 & 1960 & 1970 \\
\hline Empregadores & 1049281 & 1005701 & 624576 & 12,1 & 8,1 & 3,5 \\
\hline Empregados & 2652068 & 2743776 & 1987443 & 30,6 & 21,9 & 12,3 \\
\hline $\begin{array}{l}\text { Pequenos } \\
\text { produtores }\end{array}$ & 4956292 & 8751390 & 13481529 & 57,3 & 70,0 & 83,8 \\
\hline Total & 8657641 & 12500867 & 16093548 & 100,0 & 100,0 & $100, c$ \\
\hline
\end{tabular}

No bojo do crescimento de um conjunto dos produtores familiares, parte destes, assim como dos grandes latifúndios, foi se modernizando, como mostra a Tabela 3.

\section{Tabela 3}

DESENVOLVIMENTO ECONOMMICO* E ESTRUTURA FUNDIÁRIA (MICRORREGIŐES HOMOGENNEAS)

\begin{tabular}{|l|c|c|c|c|}
\hline \multirow{2}{*}{ Desenvolvimento } & \multicolumn{4}{|c|}{ Concentração fundiária } \\
\cline { 2 - 5 } & Muito elevada & Grande & Média & Regular \\
\hline Insuficiente & 12 & 22 & 17 & 1 \\
Pequeno & 22 & 26 & 57 & 32 \\
Médio & 13 & 34 & 32 & 20 \\
Grande & 20 & 27 & 9 & 16 \\
\hline
\end{tabular}

FONTE: SERPRO, 1977, p. 90-A.

* O desenvolvimento é medido em termos de índices que expressam o grau de avanço das forças produtivas e condições sociais do estabelecimento.

\section{A produção familiar modernizada ${ }^{8}$}

A produção familiar pode ser definida como uma categoria social, que a partir de uma base material e social específica luta pela sua reprodução contra a expropriação do excedente e a tendência de proletarização (no campo ou na cidade) que se exerce contra ela a partir do modo de produção o capitalista, ou contra a expropriação de seu excedente por parte do proprietário fundiário, ou do capital usuário e comercial. A produção do camponês, portanto, só pode ser compreendida a partir da existência das bases sociais, materiais e ideológicas específicas que servem para ele lutar pela sua reprodução o como categoria social específica, reprodução que, como vimos, pode ser tanto negativa como ampliada. Na luta para se preservar como produção familiar economicamente viável, esta deve aceitar as imposições que o sistema agroindustrial lhe coloca, e que na medida que as aceite vão modificando suas determinações, as bases de seu funcionamento, a sua especificidade material e ideológica, transformando-se crescentemente num agente integrado na sociedade capitalista.

Esta incapacidade crescente de autodefesa camponesa simbolizaria assim o processo pelo qual a integração agroindustrial vai despojando o camponês de elementos centrais que definem sua

8 Para um tratamento mais detalhado deste tema, consultar: Wanderley, N. (1979), Graziano da Silva (1979), Sandroni, P. (1980), Beskoff, P. (1979), Sorj, B. (1980), Coradini e Fredericq (1981), Tavares, J. V. (1978), Muller, G. (1981) e Lopes, J. L. (1978) 
especificidade. Isto é, a base material e ideológica que determina um tipo de confrontamento da produção familiar com o capital que é constantemente cercado pela ação da integração agroindustrial.

A situação muda drasticamente no momento em que a viabilidade econômica da unidade familiar passa a depender de sua capacidade de se atualizar tecnologicamente, ou seja, no momento em que a agroindústria passa a integrar a agricultura dentro de um processo que leva ao revolucionamento permanente dos processos produtivos. Este contexto, por sua vez, leva a aumentar a importância do capital comercial e financeiro, agroindustrial ou estatal e a eliminação do capital comercial e usuário tradicional.

Neste contexto, acelera-se violentamente o processo de diferenciação horizontal dentro do campesinato. A condição de sobrevivência dentro do novo sistema produtivo é a capacidade de adequação que só é possível gerando-se um certo excedente e/ou novo endividamento. Nestas circunstâncias, o produtor familiar bemsucedido deve reinvestir na agricultura para sobreviver, já que a reprodução simples equivale a reprodução negativa na medida em que o não melhoramento dos equipamentos implicaria que nos futuros ciclos reprodutivos se encontrará em desvantagem crescente frente aos produtores mais tecnificados.

No processo de aumento de produtividade e produção por empresa, se dá um processo de concentração da produção. Esta concentração significa fundamentalmente o aumento do capital fixo por empresa, embora não implique necessariamente uma concentração fundiária. Porém, nos casos em que preexistia uma estrutura minifundiária, o uso rentável da tecnologia agroindustrial exige concentração fundiária, daí a política de "remembramento" dos minifúndios.

As novas características da produção familiar decorrentes de sua integração na agroindústria podem ser assim resumidas ${ }^{9}$ :

A) Compulsão a mercantilizar a totalidade de sua produção. No caso do produtor familiar integrado ao complexo agroindustrial, a possibilidade de escolher entre o autoconsumo e a mercantilização da sua produção não mais existe, na medida em que a base de seus processos produtivos e as condições de sua futura reprodução se encontram totalmente monetarizadas. Isto é, nos pressupostos da produção (insumos, maquinaria e crédito) a produção agrícola surge como mercantil, e portanto, o produto deve ser forçosamente mercantilizado. A possibilidade de optar pelo autoconsumo ou pela mercantilização apareceria igualmente como um instrumento de autodefesa camponesa que assim praticamente desaparece;

Fim da permutabilidade entre terra, trabalho e capital. A opção camponesa de uso mais ou menos intensivo de um ou outro dos fatores de produção tende a desaparecer, no sentido de que a nova tecnologia é que determina crescentemente a viabilidade ou não do uso alternativo dos diferentes fatores de produção. A nova tecnologia

9 Para uma análise da modernização da pequena produção no Nordeste dentro do contexto dos Programas de Desenvolvimento Rural Integrado veja WILKINSON, J., 1982. 
determinará a quantidade mínima de terra necessária para o uso rentável, assim como imporá limites à alocação alternativa de força de trabalho familiar. Igualmente, modificará as alternativas de uso do capital monetário excedente;

C)Seleção/exclusão/concentração Os processos de concentração anteriormente mencionados determinam um constante processo de seleção/exclusão pelo qual um grupo de produtores familiares consegue adequar-se aos novos patamares técnicos e um outro é excluído. Este processo é intermitente, gerando em forma permanente um grupo de produtores familiares que não tem condições de viabilizar sua produção familiar;

D)Apropriação do conhecimento "camponês"

Para o produtor familiar, e inclusive para o trabalhador assalariado, as formas tradicionais de produção mantinham um controle de processo produtivo a partir do conhecimento adquirido na prática e das características técnicas da produção. O que fazer, quando fazer, e como fazer eram em grande parte determinados pela sua "intuição" a partir da experiência acumulada.

Nas condições de produção tecnificada, o processo produtivo passa a estar determinado pelas prescrições "externas" das empresas industriais, diretamente ou através da extensão rural, que estruturam o ritmo e as tarefas da atividade produtiva. Os porquês das prescrições técnicas permanecem desconhecidos para o trabalhador rural, que no fundamental segue as indicações dos técnicos, sob pena de não produzir resultados econômicos satisfatórios. Não somente o conhecimento é subtraído do produtor; como seu ritmo de trabalho passa a ser determinado pelas prescrições técnicas da agroindústria. Esta desapropriação do conhecimento tradicional e a imposição do ritmo de trabalho não implica, porém, que o produtor não possua ainda certas características e conhecimentos que lhe são próprios. A experiência adquirida lhe permite em forma intuitiva introduzir pequenas modificações na utilização dos insumos. Trata-se, porém, de limites muito estreitos de autonomia no processo produtivo, sem lhe dar reais condições de influir, seja nas determinações mais gerais da utilização dos insumos industriais, seja na capacidade inovadora.Particularmente nas condições de "transição acelerada" de camponês tradicional, com praticamente educação formal, às formas avançadas de agricultura tradicional, o produtor não tem condições de acompanhar, de integrar níveis mais abstratos de informação relativos à tecnologia por ele utilizada.O ritmo de trabalho, embora não seja totalmente imposto pelo ritmo da maquinaria, não deixa para o produtor maiores margens de autonomia, sob pena de não cumprir os níveis de produtividade que são a condição de sobrevivência econômica. Ainda mais quando se vê obrigado, pela impossibilidade de contratar número suficiente de trabalhadores assalariados, a assumir tarefas que vão muito além de uma jornada de oito horas de trabalho.

E)A integração econômico-ideológica. Este processo de integração é múltiplo, e nele jogam fatores materiais como ideológicos. De certa forma se poderia dizer que na atualidade a 
grande força determinando esta integração é o consumo. A necessidade de dinheiro para viabilizar a compra de produtos manufaturados - que resultam mais baratos quando comprados do que quando produzidos manualmente — já é mencionada por autores clássicos como geradores do processo de especialização e mercantilização da produção camponesa. O que se coloca hoje, porém, não é a substituição de produtos anteriormente produzidos ou de acesso no mercado tradicional, e sim a integração na estrutura de objetos de consumo ligados ao desenvolvimento da sociedade capitalista (desde remédios manufaturados até televisão e CocaCola).Essa integração camponesa no mundo ideológico burguês através do consumo não se refere a uma questão de avaliação chayanoviana racional ou subjetiva das "necessidades da família"; pelo contrário, atua como uma estrutura objetiva, determinada pela penetração dos aparelhos ideológicos e os meios de comunicação modificando o mundo cultural do campesinato.Esse processo atua obviamente não apenas em forma ideológica como material. $\mathrm{Na}$ medida em que a produção familiar se integra dentro do circuito financeiro e industrial, o funcionamento da empresa passa a exigir do próprio produtor um ritmo de integração tecnológica e financeira cada vez maior, sob pena de se proletarizar (pois o nível de integração já não permite mais um retomo a um estágio de produção para o autoconsumo). Isto gera uma dimensão específica no processo de trabalho na unidade familiar, que não sendo diretamente subordinada ao controle do capital leva a família produtora a interiorizar a racionalidade capitalista sobre si mesma de forma a manter níveis crescentes de produtividade.

F) De classe a estratos processos anteriormente mencionados resultam na transformação do campesinato, minando as bases materiais e ideológicas que o diferenciavam e o contrapunham às outras classes sociais. Os mundos simbólicos particulares, geralmente de origem pré-capitalista, tendem a se desintegrar pela ação combinada dos aparelhos ideológicos (escolas, mass media etc.), dando lugar a uma forma de sociabilidade e integração dentro das expectativas da sociedade capitalista. As formas de organização passam a se dar dentro da legalidade da ordem capitalista, através de organizações corporativistas de representação. Os interesses sociais tendem a se concentrar em reivindicações de ordem econômica que não implicam um questionamento da ordem social estabelecida. As contradições frente ao latifúndio tendem a diminuir para se concentrar nas relações com a agroindústria e as políticas públicas.

\section{Os pequenos produtores pauperizados}

Apesar da modernização da agricultura brasileira, permanece e continua crescendo um setor de pequenos produtores "tradicionais" pauperizados. Dada a importância crescente da produção capitalizada, este setor de camponeses, localizados geralmente em terras marginais, tende a ter sua importância econômica diminuída e, portanto, suas características e formas de integração na economia transformadas. 
Este fenômeno fica mais claro se o contrapomos ao desenvolvimento da agricultura no capitalismo central. Nestes países o desenvolvimento do capitalismo na agricultura determinou a redução absoluta e relativa da quantidade de força de trabalho empregada na agricultura, e, em muitos casos, a diminuição na quantidade de terras utilizadas, na medida em que os investimentos em novas técnicas se concentram nas terras de maior renda diferencial.

No Brasil, da mesma forma, temos que em certas regiões mais desenvolvidas têm diminuído a importância absoluta e relativa da população rural, e terras antigamente dedicadas à lavoura foram transformadas em pastagens. Entretanto, especialmente nas regiões com baixa industrialização, a falta de alternativas de emprego no setor urbano determina que parte da população que em outras circunstâncias teria abandonado a produção agrícola permaneça dentro dela.

Esta população inclui tanto pequenos proprietários como parceiros ou arrendatários incapazes de capitalizar as suas empresas, e que em muitos casos se assemelha a bolsões de força de trabalho desempregada, capaz de gerar sua própria subsistência. Uma das razões fundamentais deste processo é que a crescente relevância do setor agrário capitalizado (seja de pequenas ou grandes empresas) não se reflete quantitativamente em termos de absorção de mão-deobra. Nas regiões de grandes latifúndios que se modernizam, pode se dar uma diminuição total do trabalho assalariado ocupado na medida em que as formas mais avançadas de produção podem diminuir a quantidade de trabalhadores já assalariados anteriormente ocupados.

A manutenção dessa mão-de-obra pode refletir-se no crescimento das pequenas propriedades, em zonas de fronteira e em terras marginais, ou no aumento de pessoas trabalhando na mesma parcela, o que leva geralmente à diminuição crescente de produtividade por indivíduo ocupado.

Esse conjunto de produtores marginais se imbrica no processo de acumulação capitalista em forma diversa segundo seja o contexto econômico específico. Em seu caso extremo, trata-se de excedente populacional que só poderá eventualmente no futuro ser integrado pelo capitalismo ou expulso fora das — fronteiras nacionais. Por outro lado, pode integrar-se em forma de força de trabalho temporária, que permite reduzir o custo do capital variável de certos produtos agrícolas. Em outros casos, transforma-se em exército industrial de reserva utilizado em épocas de expansão econômica, ou como exército de reserva dentro do próprio campo, rebaixando o poder de barganha dos produtores familiares integrados nos circuitos de capital agroindustrial. E, finalmente, atua como fator de pressão sobre o salário industrial na medida em que permanece como massa potencial concorrente no mercado de trabalho.

As defasagens entre a liberação da força de trabalho pelo avanço do capitalismo na agricultura e a capacidade de absorção desta força de trabalho pelo setor urbano-industrial resolvem-se historicamente das mais diversas formas. Como temos visto, pode 
ocorrer a expulsão deste grupo, transformando-o desde o ponto de vista da reprodução do capital à escala nacional Gá que pode ser recuperado à escala internacional) em excedente demográfico. Ao mesmo tempo, pelo lado desta mão-de-obra surgem novas formas de organização em função de sua sobrevivência, que assumem características específicas. Assim, temos formas variadas de combinação do trabalho de diversão membros da família nas mais variadas atividades, que permitem no seu conjunto a sobrevivência da família.

Este fenômeno tem levado muitos autores a ver um tipo de "recamponesização" na medida em que a luta pela sobrevivência fortalece certos laços familiares. Contudo, trata-se, na verdade, de uma estrutura totalmente nova, divergente da estrutura familiar baseada no trabalho direto da terra, no qual o produtor tinha certo controle sobre o processo produtivo e do seu produto. Aqui a família, como célula econômica, não está baseada nas necessidades imanentes do processo de trabalho rural, tratando-se mais de uma célula de consumo, produto da impossibilidade de atingir o mínimo necessário para sua sobrevivência a partir do trabalho de cada um de seus membros. Sua dinâmica é dependente da capacidade de integração do setor urbano-industrial e dos mecanismos do ritmo de marginalização ou expulsão da produção agrária.

A massa de produtores que temos denominado de bolsões de desemprego é na verdade de difícil caracterização, no sentido que exprime processos históricos complexos, que mostram os limites das formulações alcançadas no denominado debate sobre marginalidade. Por um lado, temos que podem se dar excedentes demográficos, mas estes não são necessariamente uma "característica estrutural" do capitalismo periférico e sim um fenômeno passageiro, e relativo a cada economia nacional. Por outro lado, vemos que a marginalidade não é somente urbana, mas também rural. Finalmente, por detrás das chamadas massas marginais se encontram os mais diversos tipos de integração no processo de acumulação capitalista, assim como diversas formas de organização "familiar" que permitem a sobrevivência de seus integrantes.

O que importa assinalar é que temos uma redefinição crescente do lugar ocupado pela pequena produção tradicional. Se bem que ainda ocupe lugar importante como produtor de alimentos, sua importância como produtor direto tende a decrescer e a ser substituída por pequenos produtores capitalizados e empresas capitalistas. Desta forma, de produtores tradicionais se transformam em "marginais", com ritmos de proletarização e absorção pela economia urbano-industrial que depende em última instância da dinâmica de cada economia nacional e seus ciclos de expansão e retração e as possibilidades de absorção e expulsão da produção rural.

A empresa capitalista rural tem nesta mão-de-obra uma fonte importante de barateamento de seus custos de produção, e a própria expansão destas empresas é possibilitada pela existência desta mãode-obra. Finalmente, o grupo de pequenos produtores capitalizados deve ser estudado concretamente nas formas específicas de seu 
surgimento e de seu imbricamento com o conjunto de expansão agroindustrial.

\section{As empresas capitalistas}

A modernização dos grandes estabelecimentos agrícolas é altamente desigual. Embora se dê uma modernização rápida daquelas propriedades onde se apresenta uma alta renda diferencial (seja em termos de mercado nacional ou internacional) a tendência ã modernização do resto dos grandes estabelecimentos pode ser lenta, porque as grandes propriedades, mantendo formas de extorsão do sobretrabalho não capitalista, podem manter níveis de lucratividade maiores do que se se transformassem em empresas diretamente integradas na produção em grande escala. Esta situação pode ser quebrada por políticas públicas que "compensam" a grande propriedade e promovem a sua transformação em empresa capitalista, o que ocorreu no Brasil em forma acentuada a partir dos anos sessenta. De qualquer maneira, esta transformação é altamente desigual na medida em que a grande propriedade ocupa terras com diversas rendas diferenciais.

No caso brasileiro, a necessidade de impulsionar a modernização agrícola determinou a intervenção massiva do Estado para integrar a grande propriedade na estrutura da produção agroindustrial. A criação de grandes empresas capitalistas na agricultura passou a ser incentivada especialmente em torno da ocupação de novas áreas, sobretudo na Amazônia, com os estímulos da SUDAM, mas também no Nordeste com a SUDENE e mais recentemente com o POLOCENTRO para regiões dos cerrados. Tanto aqui como nas áreas de ocupação tradicional a grande empresa especializa-se em certos ramos como pecuária, cana-de-açúcar, reflorestamento, avicultura, fruticultura, ocupando um papel secundário na exploração de outros produtos agropecuários.

Já existem vários estudos sobre o impacto desta modernização da grande empresa na transformação das relações sociais no campo ${ }^{10}$. Aqui, portanto, limitamos nossos comentários aos efeitos mais decisivos deste processo.

A modernização da agricultura se dá através de transformações parciais de aspectos do ciclo produtivo, o que determina que a quantidade de força de trabalho seja desigual em diferentes períodos ${ }^{11}$. Nestas circunstâncias, o capital satisfaz suas necessidades através de uma força de trabalho temporária e a longo prazo, através da crescente mecanização de todas as fases de produção agrícola e a conseqüente homogeneização de suas necessidades de força de trabalho.

A formação de uma força de trabalho assalariada no campo adquire historicamente duas formas fundamentais. A primeira, que poderia ser denominada a forma tradicional, ocorre com a utilização da força de trabalho excedente da pequena produção. Trata-se de

10 Em particular os estudos de J. Graziano da Silva. Consultar, igualmente, CASTRO A. et al., 1979 e IANN1, O., 1979.

11 Cf. SILVA, J. G., 1980 
pequenos produtores relativamente cercanos à empresa agrícola capitalista, ou fixados no próprio estabelecimento através da distribuição de terras dentro de sua própria empresa. Desta forma, o trabalhador tem assegurado seu sustento durante o período em que não é necessário na empresa, sem representar para esta um ônus especial, a não ser o próprio pedaço de terra oferecido ao pequeno produtor.

O processo de valorização da terra, problemas sociais e políticos que esta forma de fixação do trabalhador pode acarretar e a concentração crescente das atividades de pique em períodos muito específicos, pelas transformações tecnológicas, tende a levar à expulsão da pequena produção dos limites da empresa capitalista. Nestas condições se apresenta o problema da formação de uma força de trabalho rural que esteja à disposição em momentos específicos do ciclo produtivo.

A modernização da grande propriedade vai quebrando as possibilidades de involução para formas de produção não capitalistas. Se, anteriormente existia uma possibilidade, em condições de mercado desfavoráveis, de retração para a subsistência, a dependência crescente de ingressos monetários para permitir a reposição do próprio ciclo produtivo (insumos e maquinaria) não permite que isto aconteça. Por sua vez, a dissolução do latifúndio leva à dissolução das estruturas tradicionais de dominação, da erosão do poder do proprietário e dos mecanismos clientelísticos de relacionamento.
A penetração de processos produtivos mais avançados tende geralmente — pelo menos num primeiro estágio — a aprofundar as necessidades desiguais da força de trabalho durante o ciclo produtivo. Assim, por exemplo, a mecanização e utilização de insumos modernos podem levar à liberação da força de trabalho na época do plantio, ao mesmo tempo em que determina o incremento da produção e as necessidades da força de trabalho na época de colheita, que ainda pode não ser mecanizada. A dinâmica de geração e expulsão da força de trabalho depende de cada produto e de seus níveis de mecanização e concentração, porém pode-se dizer que se dá uma tendência geral, com a penetração das forças produtivas mais avançadas, para a diminuição da força de trabalho ocupada na agricultura, seja temporária ou permanente.

Como conseqüência destes processos, o trabalho assalariado temporário se transformou na forma mais importante de trabalho assalariado rural no Brasil. Por sua vez, os assalariados permanentes que tendem a continuar dentro da fazenda são os trabalhadores qualificados, como tratoristas e mecânicos, na medida em que seus serviços são necessários durante todo o ano.

Podemos distinguir duas formas diferentes de trabalho assalariado - aquele resultando do assalariamento da pequena produção tradicional, e aquele que agora depende totalmente da venda de sua força de trabalho, mora em vilas ou cidades, e que eventualmente trabalha no campo e também na cidade.

Em relação a este último, a existência de uma grande massa de 269 
trabalhadores rurais com alta mobilidade estabelece um processo de unificação do mercado de trabalho nacional e determina de forma crescente uma tendência à igualação dos salários regionais, assim como dos urbanos e rurais. A tendência para esta unificação, contudo, não implica uma igualação ou homogeneização total dos salários urbano rurais. Pelo contrário, a própria mobilidade da força de trabalho é determinada pela existência de diferenças salariais a partir do desenvolvimento desigual das empresas capitalistas, de maneira que a homogeneização do salário é no melhor dos casos a permanente criação/destruição de uma média salarial hipotética em torno da qual gira o salário de uma categoria de trabalhadores. Isso sem considerar que, a partir de níveis diferentes de produtividade e capacidade de pressão sindical, se criam diferenças salariais mais ou menos permanentes no setor.

\section{As perspectivas políticas}

O governo militar brasileiro, vale assinalar rapidamente, embora tenha tido nas grandes propriedades do campo uma das forças de sustentação social do golpe de março de 1964, tinha nos setores avançados da grande indústria e das finanças a base real do novo modelo econômico e a força dinamizadora da nova fase de expansão capitalista em que o Brasil entrara na segunda metade da década de sessenta.

Embora chegando a favorecer os grandes proprietários, as políticas estatais terão como objetivo a reestruturação da base produtiva da agropecuária brasileira integrando-a ao complexo agroindustrial de insumos e maquinarias agrícolas e â indústria de transformação de alimentos e fibras.

A deterioração dos mecanismos tradicionais de dominação do campo, que gerou as mobilizações no período anterior ao golpe de 64, colocou frente â burguesia a tarefa de renovar a estrutura de dominação a partir de um papel ativo do Estado. A repressão, decisiva no início, tende a ser substituída por novas estruturas político-ideológicas e econômicas de dominação.

Foi justamente com a consolidação do Estado autoritário que se efetivou a sindicalização rural em massa. Formados no contexto da liquidação dos antigos movimentos sociais, estes sindicatos rurais, atrelados ao Estado, deixaram pouco espaço para mobilização autônoma. Mais ainda, os critérios de enquadramento sindical baseados no "módulo" de propriedade rural imprimem um caráter interclassista a sua atividade, com produtores familiares ora nos sindicatos patronais, ora junto aos "bóias-frias". Sua atuação, portanto, se confronta com a extrema fragmentação social do mundo rural, desde assalariados a produtores familiares, onde a integração agroindustrial está avançada.

Além dos sindicatos, as formas de integração no Estado burguês atualmente em curso se dão no sentido da criação de organizações de cooperativas, serviços e projetos específicos de reordenação da estrutura fundiária junto com os mecanismos gerais de penetração ideológica, como os meios de comunicação de massa e 
educação.

As cooperativas se apresentam como mecanismo através do qual o Estado disciplina o pequeno produtor no uso de crédito e insumos modernos, ao mesmo tempo que oferece ao Estado uma organização relativamente fácil de penetrar e manipular, seja pela própria tendência das direções das cooperativas a se desvincular das bases, seja através dos mecanismos materiais e legais pelos quais a cooperativa depende do Estado. A estrutura de serviços que o Estado está introduzindo no campo, como aposentadoria, serviço médico e educação, já são e serão utilizados de maneira crescente, como instrumentos de controle e integração ideológica da população rural.

Em certos casos, políticas orientadas para acelerar a diferenciação interna entre os próprios produtores familiares podem ser claramente indicadas. Assim, por exemplo, os projetos em regiões atrasadas, em que a promoção de certas camadas de pequenos agricultores visa diferenciar e privilegiar um setor do resto, como é o caso do POLONORDESTE. Por outro lado, em regiões de grande conflito social o Estado pode intervir com políticas de cooptação através do INCRA ou órgãos especiais (GETAT).

Temos, portanto, que o governo se utiliza de forma diferenciada, num contexto altamente dinâmico e socialmente fragmentado, segundo as diferentes categorias sociais no campo, de diversos mecanismos de integração e dominação, adaptando-se à heterogeneidade do campo, embora promovendo sempre a modernização sob a égide do contexto agroindustrial.
Porém, a própria violência deste processo e os efeitos da subordinação do setor agrícola ao conjunto da economia numa época de crise tendem a promover movimentos que escapam ao controle destas políticas.

Estes se expressam sobretudo a nível regional com a Igreja e os sindicatos do Norte e Nordeste forçados a uma crescente intervenção na questão da terra ou na fixação de salários, enquanto que no Sul, eles vêm articulando movimentos de massa contra a política de preços agrícola (como nos casos dos suinocultores em Santa Catarina e os produtores de soja no Rio Grande do Sul).

Contudo, o próprio exemplo do Rio Grande do Sul mostra que uma articulação puramente regional é incapaz de unificar as lutas no campo. Neste estado, enquanto os sindicatos articulam as reivindicações setoriais e corporativistas dos produtores capitalizados, inclusive no contexto de mobilizações em massa, os trabalhadores sem terras se movimentam para a ocupação de latifúndios sem nenhum respaldo por parte destes mesmos sindicatos.

Como consequiência, uma estratégia para o campo, hoje, tem de partir de um reconhecimento da heterogeneidade estrutural de suas forças sociais, que compõem trabalhadores rurais, produtores familiares capitalizados e pequenos produtores pauperizados. Embora a predominância de uma ou outra destas forças se expresse em primeiro lugar a nível regional, com o avanço da agro industrialização do campo, esta heterogeneidade se consolida e forma o difícil contexto em que a unificação das lutas no conjunto do 
campo brasileiro deve ser buscada. Por sua vez, com a crescente integração do campo nos circuitos de capital agroindustrial e financeiro, a resolução da questão agrária deixa de ser uma problemática setorial, e deve ser colocada no contexto de alternativas estruturais para o conjunto do modelo econômico e político.

\section{ANEXO}

Dados básicos sobre a estrutura fundiária e utilização de maquinarias e insumos agrícolas

POPULAÇÃ̄o POR SITUAÇĀo DO DOMICILIIO NAS DATAS dOS RECENSEAMENTOS GERAIS POR REGIĀo

\begin{tabular}{|l|r|r|r|r|r|c|}
\hline \multirow{2}{*}{ Regí̈es } & \multicolumn{3}{|c|}{ População urbana } & \multicolumn{3}{|c|}{ Populaçă rural } \\
\cline { 2 - 7 } & \multicolumn{1}{|c|}{1960} & 1970 & 1980 & 1960 & 1970 & 1980 \\
\hline Brasil & 32004817 & 52904744 & 82013375 & 38987526 & 41603810 & 39137198 \\
\hline Norte & 983278 & 1649430 & 3102659 & 1618241 & 2001320 & 2925902 \\
\hline Nordeste & 7680681 & 11980937 & 17959640 & 14748192 & 16694144 & 17459516 \\
\hline Sudeste & 17818649 & 29347170 & 43550664 & 13244329 & 10984799 & 9029863 \\
\hline Sul & 4469103 & 7434196 & 12153971 & 7423004 & 9249355 & 7226155 \\
\hline Centro-Oeste & 1053106 & 2493011 & 5246441 & 1953760 & 2674192 & 2495762 \\
\hline
\end{tabular}

FONTE: FIBGE, Sinopse Preliminar do Censo Demografico de 1970 e 1980.
Tabela 2

UTILIZAÇĀo dAS TERRAS SEGUNDO AREA E POR REGIÓES DA FEDERAÇĀo

\begin{tabular}{|c|c|c|c|c|c|c|c|c|}
\hline \multirow{3}{*}{ Regiós } & \multicolumn{5}{|c|}{ Lavoura (ha) } & \multicolumn{3}{|c|}{ Pastagens (ha) } \\
\hline & \multirow{2}{*}{\begin{tabular}{|c|}
$1960^{\circ}$ \\
Temp + Perm
\end{tabular}} & \multicolumn{2}{|c|}{1970} & \multicolumn{2}{|c|}{1980} & \multirow{2}{*}{1960} & \multirow{2}{*}{1970} & \multirow{2}{*}{1980} \\
\hline & & Temp & Perm & Temp & Perm & & & \\
\hline Brasil & 28712209 & 25999728 & \begin{tabular}{|l|l}
7984068 \\
\end{tabular} & 38687995 & 10497307 & 122335386 & 154138529 & 165652250 \\
\hline Norte & 432302 & 484765 & 132366 & 1208287 & 555226 & 2219749 & 4428116 & 5281440 \\
\hline Nordeste & 8727690 & 6344971 & 3977911 & 9433819 & 4848502 & 21657278 & 27875111 & 30624044 \\
\hline Sudeste & 9928241 & 7439430 & 2172973 & \begin{tabular}{|l|l|}
8563727 \\
\end{tabular} & 3555477 & 38380808 & 44739276 & 47276785 \\
\hline Sul & 8204087 & 9471206 & 1557247 & 13330967 & 1209150 & 18226917 & 21612679 & 21159758 \\
\hline cen & 1385879 & 2259356 & 143570 & 6151194 & 328949 & - & 55484328 & 61310221 \\
\hline
\end{tabular}

ONTE: FIBGE, Conso Agropecusfrio de 1960, 1970, 1975 e 1980

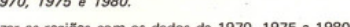

\begin{tabular}{|c|c|c|c|c|c|c|}
\hline \multicolumn{7}{|c|}{$\begin{array}{c}\text { Tabola } 3 \\
\text { NUMERO DE ESTABELECIMENTOS POR AREA - } 1960,1970,1980 \text { POR REGIÖES DA FEDERAGĀO }\end{array}$} \\
\hline \multirow{2}{*}{ Regiies } & \multicolumn{3}{|c|}{ Estabelecimentos } & \multicolumn{3}{|c|}{ Areas } \\
\hline & $1960^{\circ}$ & 1970 & 1980 & 1960 & 1970 & 1980 \\
\hline Brasil & 3337769 & 4924019 & 5167578 & 249862142 & 294145466 & 369587872 \\
\hline Norte & 138241 & 261145 & 409787 & 23453086 & 23182145 & 4254602 \\
\hline Nordeste & 1408114 & 2206788 & 2450701 & 62990438 & 74298713 & 89555112 \\
\hline Sudeste & 824407 & 928945 & 892532 & 64438763 & 69500950 & 73973813 \\
\hline Sul & 807615 & 1274009 & 1146578 & 38994290 & 45458035 & 4818498 \\
\hline Centro-Oeste & 159392 & 253132 & 267980 & 59986565 & 81705624 & 11532793 \\
\hline
\end{tabular}

Tabola 4

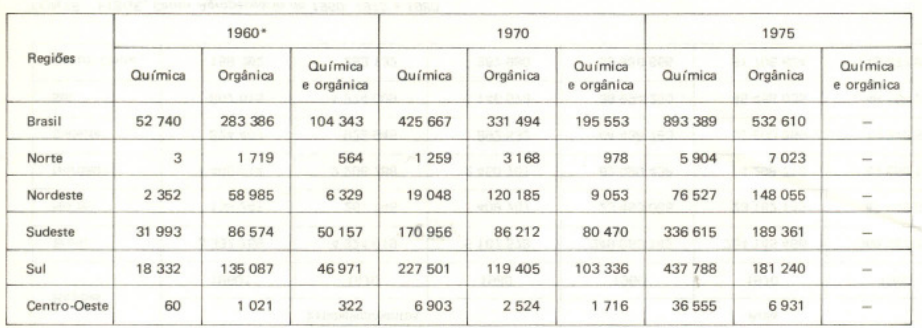

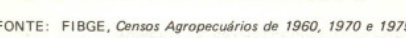

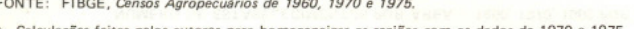


SORJ, B., Estado e classes socias, na agricultura brasileira, Rio de Janeiro, Zahar, 1980.

SORJ, B., POMPERMAYER, M. e CORADINI, O. L., Camponeses e agroindústria, Rio de Janeiro, Zahar, 1982.

TAVARES DOS SANTOS, J. V., Colonos do vinho, São Paulo, HUCITEC, 1978. WANDERLEY, N., "O camponês: um trabalhador para o capital", 1979, mimeo.

WILKINSON, J., "The state, agroindustry and small farmer modernization", Ph. D.Thesis, University of Liverpool, 1982.

\section{O sindicalismo brasileiro entre a conservação e a mudança}

Maria Hermínia Tavares de Almeida ${ }^{1}$

Muitas foram as transformações experimentadas pelo sindicalismo brasileiro nos últimos vinte anos. A natureza e o significado dessas mudanças deram motivo a alguma controvérsia entre os cientistas sociais. Contudo, para além de toda polêmica, os analistas convergem no reconhecimento de que existe algo de fundamentalmente novo a distinguir o movimento sindical de hoje daquele que marcou presença na cena pública, nos tempos do populismo.

Até o presente, as atenções estiveram focalizadas no novo sindicalismo operário que, gerado no universo da grande indústria moderna, foi inovador no plano das aspirações sócio-profissionais, em sua prática sindical e no estilo de fazer política.

Já é hora de tentar uma visão mais abrangente do movimento sindical brasileiro, que ganhou o espaço público no final dos anos setenta. A tarefa é difícil por mais de uma razão. O que se segue não tem a pretensão de ser um quadro acabado de uma realidade complexa e desigualmente conhecida. e antes um esboço, a ser

1 Professora do Instituto de Filosofia e Ciências Humanas da Universidade Estadual de Campinas, São Paulo, Brasil. Colaboradora do Centro Brasileiro de Análise e Planejamento (CEBRAP). Agradeço a Helena Urbano e Elza Hobus. que realizaram o levantamento das greves, e a Sérgio Amad Costa, que construiu as tabelas e realizou a pesquisa sobre as eleições sindicais. 
completado ou refeito, através do debate e de outros estudos.

\section{Um sindicalismo minoritário e de massas}

Com frequiência, no Brasil, a literatura especializada enfatizou a fraqueza de nosso sindicalismo, manifesta na sua reduzida gravitação sobre o mercado de trabalho e, em conseqüência, em seu exíguo poder de barganha vis-à-vis as empresas.

Da mesma forma, não foram poucos os que focalizaram a atenção sobre outro aspecto dessa debilidade, o da pouca representatividade das entidades sindicais, investidas de um monopólio de representação que lhes é assegurado por lei e não por livre deliberação das bases. ${ }^{2}$

Nessa avaliação severa - mas nem por isso destituída de realismo os baixos índices de sindicalização foram sempre tomados como indicadores privilegiados daquelas vicissitudes. E, de fato,

2 A estrutura sindical brasileira é definida pela Consolidação das Leis do Trabalho de 1942. De acordo com a lei, constituem-na três tipos de entidades, a saber: 1) sindicatos de categoria profissional, de base municipal, sem representação nos locais de trabalho. A categoria profissional é definida pela atividade principal da empresa empregadora, por uma comissão de enquadramento existente no Ministério do Trabalho. O Sindicato é único na sua base territorial e detém a prerrogativa de representação de todos os trabalhadores, sindicalizados ou não, perante as organizações patronais correspondentes; 2) federações - compostas por todos os sindicatos da mesma categoria profissional no âmbito estadual. Ex.: Federação dos Metalúrgicos do Estado de São Paulo; 3) confederações - congregando, no plano nacional, as federações pertencentes a grandes setores de atividade: indústria, agricultura, comércio, transportes terrestres, marítimos e fluviais; transportes urbanos, setor financeiro e bancário. educação e cultura, profissionais liberais. historicamente, os sindicalizados formaram — e formam ainda agora — uma fração reduzida da população trabalhadora, mesmo quando se considera apenas seu contingente urbano o que se observa nas Tabelas 1 e 2 .

Como se vê, a taxa de sindicalização do conjunto dos trabalhadores urbanos sofreu pequena elevação nos últimos vinte anos; experimentou um acréscimo ínfimo no setor industrial, enquanto que no comércio mostrou crescimento digno de nota.

Níveis de sindicalização tão persistentemente modestos lançam luz sobre as fronteiras reais do fenômeno sindical, que sempre disse — e salvo honrosas exceções, continua dizendo — respeito a parcela minoritária das camadas assalariadas.

Tabela 1

BRASIL - PORCENTAGEM DA PEA URBANA CONSTITUIDA POR EMPREGADOS SINDICALIZADOS

$$
\text { 1940-1978 }
$$

\begin{tabular}{|c|c|c|c|}
\hline Anos & Homens & Mulheres & Total \\
\hline 1940 & $9,0 \%$ & $3,0 \%$ & $8 \%$ \\
1960 & $14,2 \%$ & $6,2 \%$ & $12,0 \%$ \\
1970 & $15,7 \%$ & $6,5 \%$ & $13,0 \%$ \\
1976 & $15,5 \%$ & $6,8 \%$ & $12,5 \%$ \\
1977 & $15,8 \%$ & $6,6 \%$ & $12,5 \%$ \\
1978 & $17,6 \%$ & $8,0 \%$ & $14,1 \%$ \\
\hline
\end{tabular}

FONTE: L. Gitahy, H. Hirata, E. Lobo, R. Moisés, Trabalho assalariado, sindicalização e reivindicações operárias, São Paulo, I Congresso de Sociólogos, 1981 mimeo. 
Tabela 2

BRASIL - EMPREGADOS SINDICALIZADOS COMO PROPORÇÃO DA PEA NA INDÚSTRIA E NO COMÉRCIO

1960-1978

\begin{tabular}{|c|c|c|c|c|c|c|}
\hline \multirow[b]{2}{*}{ Anos } & \multicolumn{3}{|c|}{ Indústria } & \multicolumn{3}{|c|}{ Comércio } \\
\hline & $\begin{array}{l}\text { PEA } \\
\text { (a) }\end{array}$ & $\begin{array}{l}\text { Sindicali- } \\
\text { zados } \\
\text { (b) }\end{array}$ & & $\begin{array}{l}\text { PEA } \\
\text { (a) }\end{array}$ & $\begin{array}{l}\text { Sindicali- } \\
\text { zados } \\
\text { (b) }\end{array}$ & \\
\hline 1960 & 3012604 & 692184 & 22,97 & 1486797 & 203469 & 13,68 \\
\hline 1970 & 5424362 & 1239363 & 22,84 & 2263539 & 364590 & 16,10 \\
\hline 1976 & 9322636 & 2079607 & 22,30 & 3723495 & 672991 & 18,07 \\
\hline 1977 & 10051100 & 2273654 & 22,62 & 3878918 & 744222 & 19,18 \\
\hline 1978 & 10833957 & 2507026 & 23,14 & 4294839 & 864485 & 20,12 \\
\hline
\end{tabular}

FONTE: FIBGE, Anuário Estatístico do Brasil de 1970 e 1980.

Todavia, o reconhecimento da modéstia e constância das taxas de afiliação sindical não pode obscurecer um fato significativo: em termos absolutos houve um enorme acréscimo do contingente de trabalhadores sindicalizados.

Entre 1960 e 1978 o número de sindicalizados aumentou 3,5 vezes entre os empregados urbanos e 3,6 vezes entre os chamados profissionais liberais. ${ }^{3}$ Esse crescimento foi de $389 \%$ para os trabalhadores de educação e cultura, $299 \%$ no setor de comunicações e publicidade, $259 \%, 262 \%$ e $327 \%$ para os empregados em estabelecimentos de crédito, na indústria e no comércio, respectivamente.

Tabela 3

BRASIL - EVOLUÇÃO DO NÚMERO DE SINDICALIZADOS ENTRE EMPREGADOS URBANOS, PROFISSIONAIS LIBERAIS E EMPREGADOS RURAIS 1960-1978

\begin{tabular}{|c|c|c|c|c|c|c|}
\hline \multirow{2}{*}{ Setor } & \multicolumn{2}{|c|}{ Empregados urbanos } & \multicolumn{2}{|c|}{ Profissionais liberais } & \multicolumn{2}{|c|}{ Empregados rurais } \\
\cline { 2 - 7 } & $\begin{array}{c}\text { Números } \\
\text { absolutos }\end{array}$ & Indice & $\begin{array}{c}\text { Números } \\
\text { absolutos }\end{array}$ & Indice & $\begin{array}{c}\text { Números } \\
\text { absolutos }\end{array}$ & Indice \\
\hline 1960 & 1217655 & 100 & 40491 & 100 & - & - \\
\hline 1965 & 1602021 & 131 & 50913 & 125 & $\mathrm{n} / \mathrm{s}$ & $\mathrm{n} / \mathrm{s}$ \\
\hline 1970 & 2132086 & 175 & 72969 & 180 & $\mathrm{n} / \mathrm{s}$ & $\mathrm{n} / \mathrm{s}$ \\
\hline 1975 & 3224425 & 264 & 118866 & 293 & 3008943 & 100 \\
\hline 1978 & 4271450 & 350 & 147307 & 364 & 4568412 & 151 \\
\hline
\end{tabular}

FONTE: Centro de Documentação e Informática do Ministério do Trabalho FIBGE, Anuário Estatístico.

3 São considerados profissionais liberais os membros de uma série de profissões, cujo exercício é regulamentado por lei, independentemente do fato de seus membros trabalharem por conta própria ou como assalariados. São elas: assistentes sociais, advogados, médicos, odontologistas, farmacêuticos, engenheiros, químicos, economistas, compositores, artistas, músicos, políticos, escritores, jornalistas, arquitetos, técnicos de administração, psicólogos, sociólogos. 
Tabela 4 $1960-1978$

\begin{tabular}{|c|c|c|c|c|c|c|c|c|}
\hline \multirow[t]{2}{*}{ Anos } & Indústria & Comercio & $\begin{array}{l}\text { Transportes } \\
\text { martitimos. } \\
\text { fluviias } \\
\text { aefreos }\end{array}$ & $\begin{array}{c}\begin{array}{c}\text { Transportes } \\
\text { terrestres }\end{array} \\
\text { es }\end{array}$ & $\begin{array}{l}\text { Estabeleci- } \\
\text { mento de } \\
\text { credito }\end{array}$ & 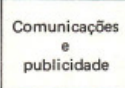 & $\begin{array}{l}\text { Educacaño } \\
\text { e cultura }\end{array}$ & $\begin{array}{l}\text { Profissionais } \\
\text { liberais" }\end{array}$ \\
\hline & $\begin{array}{c}\text { Sindicali- } \\
\text { zados }\end{array}$ & $\begin{array}{c}\text { Sindicali- } \\
\text { zados }\end{array}$ & $\begin{array}{c}\text { Sindicali- } \\
\text { zados }\end{array}$ & $\begin{array}{c}\text { Sindicali- } \\
\text { zados }\end{array}$ & $\begin{array}{c}\text { Sindicali- } \\
\text { zados }\end{array}$ & $\begin{array}{c}\text { Sindicali- } \\
\text { zados }\end{array}$ & $\begin{array}{c}\text { Sindicali- } \\
\text { zados }\end{array}$ & $\begin{array}{c}\text { Sindicali- } \\
\text { zados }\end{array}$ \\
\hline 1960 & $\begin{array}{l}(100) \\
692184\end{array}$ & $\begin{array}{c}(100) \\
203469\end{array}$ & $\begin{array}{l}(100) \\
89 \\
895\end{array}$ & $\begin{array}{c}(100) \\
122466\end{array}$ & $\begin{array}{l}(100) \\
67670\end{array}$ & $\begin{array}{l}(100) \\
25476\end{array}$ & $\begin{array}{l}\stackrel{(100)}{100} \\
17255\end{array}$ & $\begin{array}{l}(100) \\
40491\end{array}$ \\
\hline 1965 & $\begin{array}{c}(137) \\
954309 \\
\end{array}$ & $\begin{array}{c}\text { (1099) } \\
223195\end{array}$ & $\begin{array}{l}1968) \\
86688\end{array}$ & $\begin{array}{c}(121) \\
148688\end{array}$ & $\begin{array}{c}(160) \\
108456\end{array}$ & $\begin{array}{l}(184) \\
46947\end{array}$ & $\begin{array}{l}(198) \\
34238\end{array}$ & $\begin{array}{r}(125) \\
50913 \\
\end{array}$ \\
\hline 1970 & $\begin{array}{c}(179) \\
1239363\end{array}$ & $\begin{array}{r}(179) \\
364590\end{array}$ & $\begin{array}{l}(104) \\
93042\end{array}$ & $\begin{array}{c}(147) \\
180295\end{array}$ & $\begin{array}{c}(209) \\
142010\end{array}$ & $\begin{array}{l}(231) \\
58937\end{array}$ & 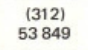 & $\begin{array}{r}(229) \\
92867\end{array}$ \\
\hline 1975 & $\begin{array}{c}(274) \\
1901237\end{array}$ & $\begin{array}{c}(299) \\
608466\end{array}$ & $\begin{array}{c}(122) \\
109259\end{array}$ & $\begin{array}{l}(209) \\
256870\end{array}$ & $\begin{array}{c}(268) \\
181592\end{array}$ & $\begin{array}{r}(335) \\
85531\end{array}$ & $\begin{array}{l}(472) \\
81470\end{array}$ & $\begin{array}{c}(309) \\
125241\end{array}$ \\
\hline 1978 & $\begin{array}{c}(362) \\
2507026\end{array}$ & $\begin{array}{r}1427) \\
869485\end{array}$ & $\begin{array}{c}(120) \\
107681\end{array}$ & $\begin{array}{r}(291) \\
357498\end{array}$ & $\begin{array}{r}1359) \\
243491 \\
\end{array}$ & $\begin{array}{c}(399) \\
101725\end{array}$ & $\begin{array}{l}(489) \\
84544 \\
\end{array}$ & $\begin{array}{r}(363) \\
147307\end{array}$ \\
\hline
\end{tabular}

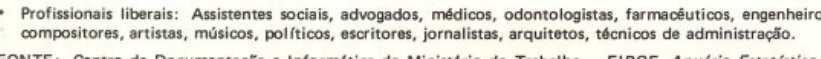
FONTE: Centro de Documentaçăo e Informática do Ministerio do Trabalho - FIBGE, Anuário Estatístico.

Em 1960, os sindicatos ainda não haviam chegado ao campo e, no meio urbano, organizavam pouco menos de um milhão e meio de pessoas. Dezoito anos depois, os trabalhadores sindicalizados formavam uma massa de quase 10 milhões, dos quais pouco mais da metade na zona rural.

Naturalmente, os dados devem ser tomados pelo que são; uma medida imprecisa da adesão formal aos sindicatos, que nada informa sobre o grau de participação efetiva dos associados na vida de suas entidades representativas. ${ }^{4}$ Todavia, tratados com a devida cautela,

4 Sabido, por exemplo, que muitos são os casos de trabalhadores que se associam ao sindicato para auferir os serviços médicos e odontológicos proporcionados pelas entidades. De outra parte, tudo parece indicar que a sindicalização rural sofreu grande estímulo a partir do momento em que os benefícios da Previdência Social foram estendidos aos trabalhadores do podem ser considerados um indicador eloqüente do fato de que, à diferença do passado, hoje, o movimento sindical brasileiro tem, virtualmente, uma base de massas. Em graus e formas variáveis, cerca de 10 milhões de trabalhadores fazem parte do mundo dos sindicatos e constituem um potencial de mobilização de porte significativo.

As transformações do sindicalismo não se restringiram a mudanças de escala. Elas implicaram alterações na posição e importância relativas dos diversos segmentos das classes trabalhadoras, enquanto eixos da atividade sindical. Nos últimos anos de sua existência, o sindicalismo populista tinha seu centro de gravidade entre os trabalhadores em serviços coletivos, via de regra geridos pelo Estado - transportes urbanos, marítimos e ferroviários e serviços portuários — assim como entre os assalariados das grandes empresas produtivas estatais, sobretudo, refinarias de petróleo.

No período recente, os trabalhadores da grande indústria de ponta - automobilística, metalmecânica, siderúrgica, petrolífera formam a espinha dorsal do movimento sindical, que se apóia, também, sobre dois outros pilares: os profissionais assalariados de "classe média" e os trabalhadores do campo. Essa realidade, que pode ser vislumbrada apenas parcialmente com os dados anteriormente apresentados, é confirmada por outros indicadores, como a

campo, através do FUNRURAL, em 1971, uma vez que a gestão da Previdência Rural foi entregue aos sindicatos. 
participação em congressos sindicais e, especialmente, a atividade grevista, examinada mais adiante.

$\mathrm{Na}$ Tabela 5 observa-se a participação relativa das diferentes entidades rurais e urbanas na I Conferência Nacional das Classes Trabalhadoras (I CONCLAT), realizada em agosto de 1981. Esta Conferência, que pela primeira vez nos últimos dezoito anos reuniu trabalhadores da cidade e do campo, é considerada por observadores, analistas e participantes muito representativa da realidade do movimento sindical brasileiro.

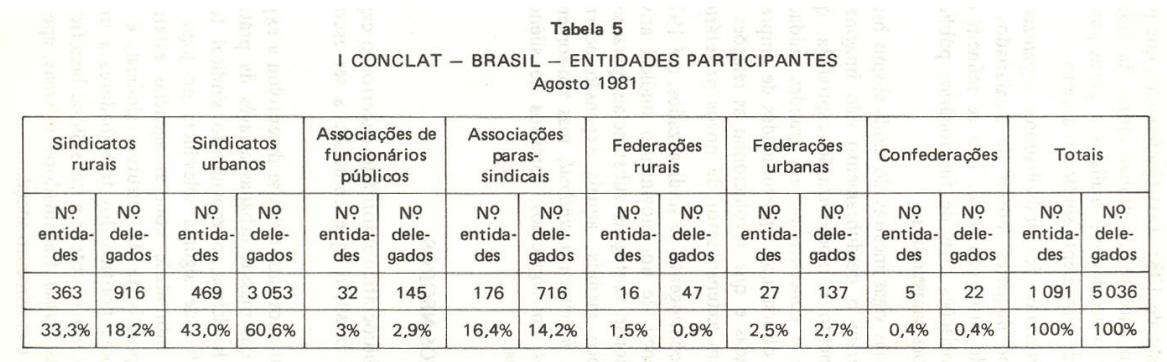

FONTE: C.I.D.A.S. - Tudo sobre a I CONCLAT - São Paulo, Comissão Nacional Pró-Cut, 1981.

NOTA: As delegaçöes por entidade foram compostas da seguinte maneira:

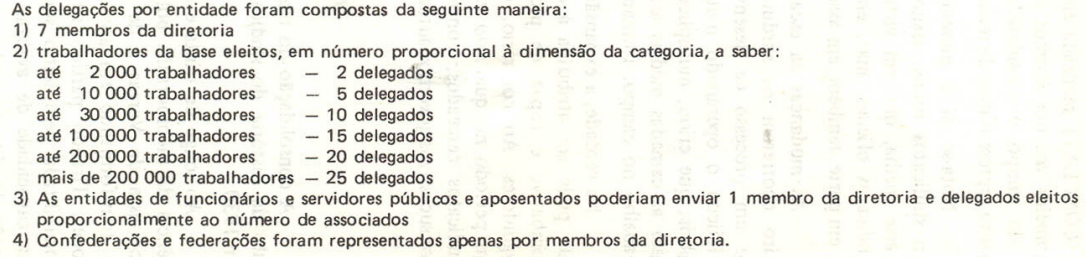

Nota-se aí a presença destacada dos trabalhadores organizados em sindicatos rurais, assim como daqueles setores de assalariados de classe média, que em virtude de proibição legal, não se reúnem em sindicatos oficiais, mas, em associações civis de funcionários públicos e, em parte, também, em associações parassindicais.

As mudanças na escala e nas vigas mestras do sindicalismo brasileiro ocorreram na surdina. Foram o desdobramento não imaginado de um processo de desenvolvimento e modernização capitalista, que triplicou o operariado industrial e concentrou-o em grandes unidades fabris; que criou, multiplicou e diversificou oportunidades de emprego para as camadas médias assalariadas e que revolucionou as relações de trabalho no campo, formando um extenso setor de novos proletários.

Na verdade, a expansão do contingente de sindicalizados, até 1978, não pode ser atribuída à existência de um movimento sindical ativo, combativo e capaz de proporcionar vantagens substanciais para seus seguidores. Ao contrário, em boa medida, aquela expansão ocorreu em período no qual não existiu movimento sindical, mas tãosomente sindicatos cerceados, controlados, enfraquecidos, forçados ao silêncio por sucessivos governos autoritários.

\section{Os anos negros}

A consolidação do regime burocrático-autoritário encerrou o capítulo da história do sindicalismo brasileiro que começara a ser escrito em 1930.

Ao longo de trinta e quatro anos, nos quais se desenrolou a experiência de incorporação política das massas urbanas através da prática populista de Vargas e de seus herdeiros, o movimento sindical fora se transformando em ator coletivo de alguma relevância no jogo 
de poder. Tirando partido de sua intimidade com as agências estatais, possibilitada pelo feitio semicorporativista da estrutura sindical, e de sua capacidade de avalizar o apoio político dos trabalhadores a uma facção da elite no poder, o sindicalismo obteve e consolidou benefícios materiais e projeção social para as massas trabalhadoras urbanas, apesar de sua fraqueza, como organização e movimento social.

Tudo isso veio abaixo quando as Forças Armadas assumiram as rédeas do Estado, em abril de 1964. Sua ascensão inaugurou a nova ordem autoritária, sob a qual floresceu um pacto de domínio grão-burguês, fundado na exclusão social das massas trabalhadoras e no garroteamento político do movimento operário e sindical.

Sobre o movimento sindical abateu-se uma repressão de duas faces: policial e burocrático-legal.

A coação policial, efetiva ou potencial, reforçou e deu maior eficácia à repressão burocrático-legal. Esta exerceu-se pelo cumprimento de uma legislação trabalhista que, herdada dos anos da ditadura varguista, cerceava a liberdade e a autonomia sindicais e consagrava múltiplos mecanismos de subordinação dos sindicatos ao Ministério do Trabalho. Caídos em desuso no período da democracia populista, estes recursos legais foram desenterrados pelos novos governantes, que os aprimoraram por meio de novas leis. Destarte, a repressão burocrático-legal foi levada a cabo pelo Ministério do Trabalho, seja por meio de dispositivos previstos na Consolidação das Leis do Trabalho desde 1942, tais como o controle sobre a aplicação dos recursos sindicais e a faculdade ministerial de destituir diretorias sindicais "subversivas", seja pela limitação do direito de greve e a abolição efetiva da negociação salarial, impostas no pós-64.

Usando de prerrogativa facultada pela legislação sindical, o Ministério do Trabalho, entre 1964 e 1970, praticou 536 intervenções em entidades sindicais, destituindo diretorias em exercício e nomeando interventores. Destas, 432 (80,6\%) ocorreram em 1964 e 1965. Neste período, foram realizadas 383 intervenções em sindicatos, 45 em federações e 4 em confederações, atingindo 18,75 dos sindicatos, $42 \%$ das federações e $82 \%$ das confederações existentes. No Estado de São Paulo, coração do sistema econômico brasileiro, 115 sindicatos e 7 das 18 federações sofreram intervenção ministerial.127

Não foram poucas as lideranças e ativistas sindicais perseguidos, presos e processados, sobretudo na fase de implantação do regime e em certos momentos de endurecimento (69-70). Entre 1964 e 1969108 dirigentes sindicais e representantes políticos dos trabalhadores foram punidos com suspensão de seus direitos políticos e perda de seus mandatos parlamentares.

De mais a mais, a simples ameaça de coerção, em um regime que a permitia arbitrária e sem controle, constituiu poderoso instrumento de obtenção de silêncio e conformismo.

127 Angelina Cheihub Figueiredo, Política Governamental e funções sindicais, 1975, mimeo. 
Entretanto, a dupla coerção sobre as entidades sindicais não se exerceu com a mesma intensidade no pós-64. Passado o período punitivo (64-65) ela afrouxou claramente, dando cabida ao renascimento da atividade sindical de oposição à política trabalhista do autoritarismo.

Essa reativação nutriu-se, na base, do descontentamento provocado pelos efeitos de uma política econômica recessiva, cujo pilar foi a contenção dos salários. E seu centro de gravidade, não por acaso, localizou-se entre os trabalhadores das grandes empresas industriais metalúrgicas do Centro-Sul do país (São Paulo e Minas Gerais). Na cúpula, ela tomou a forma de aceso debate sobre a atuação sindical no passado recente. Grupos dissidentes do Partido Comunista criticaram acerbamente a prática sindical desta agremiação no período populista, acusando-a de imprimir urna condução política moderada, acomodatícia, emaranhada nas transações da grande política e pouco atenta à organização de base.

O encontro de lideranças esquerdistas dissidentes, adeptas de uma política enfaticamente mobilizadora e de enfrentamento aberto com o, governo autoritário, com uma massa de trabalhadores numerosa, concentrada e descontente, desembocou, em 1968, em duas explosões grevistas violentas e violentamente reprimidas pelo governo. ${ }^{128}$

128 Ao longo de 1968, realizaram-se duas greves no distrito industrial de Contagem, Minas Gerais, e uma greve no município industrial de Osasco,
A partir de então, o movimento sindical praticamente desapareceria e os sindicatos mergulharam em uma longa fase de silêncio, reforçado pelo recrudescimento dos aspectos autoritários do regime político, que já atingiu não apenas os trabalhadores mas toda a sociedade.

O autoritarismo exacerbado estrangulou o movimento sindical, mas não fechou os sindicatos. Estes continuaram a executar as rotinas previstas na legislação trabalhista. Participavam anualmente da renovação dos acordos salariais coletivos, transformada em ritual de homologação dos percentuais de reajustes ditados pelo governo. E, sobretudo, ocupavam-se da gestão dos serviços assistenciais vários, que constituíam a destinação obrigatória dos recursos obtidos com a contribuição sindical: assistência jurídica, assistência médica e odontológica, cursos, bibliotecas, colônias de férias etc.

Contraditoriamente, a função assistencialista, que pervertia e desnaturava o sindicato como arma de combate, permitiu que não se cortassem por completo seus vínculos com a base. Novos associados continuaram a procurar o sindicato, para fazer uma consulta médica, cortar o cabelo ou processar seu empregador na Justiça do Trabalho.

Por outro lado, a política excludente e coercitiva dos governos

perto de São Paulo, rompendo o silêncio do movimento sindical, imposto pelos governos autoritários. Em Osasco a paralisação atingiu todas as grandes empresas metalúrgicas da região, apoiada na extensão de um movimento de organização de comissões de empresa. Num contexto extremamente radicalizado ocorreu a ocupação e tomada de reféns em uma das empresas da região, seguida de violenta repressão policial. 
autoritários, se era capaz de obter submissão pelo medo, punha limites estreitos à criação de uma burocracia sindical nitidamente governista. Um juízo extremamente crítico das limitações criadas pela estrutura sindical e pela política trabalhista dos governos autoritários predominou mesmo entre as lideranças aparentemente mais acomodadas e menos dispostas a arriscar seus cargos com ações agressivas. $^{129}$

Como a vida não se esvaiu de todo dos sindicatos e a insatisfação muda predominou entre as lideranças, não é de se estranhar que os conflitos resultantes da perversa combinação entre desenvolvimento econômico acelerado, exclusão social e autoritarismo político terminassem por ganhar expressão no mundo sindical.

Por volta de 1973, uma voz isolada mas potente verbalizou alto e bom som uma crítica contundente à política social e trabalhista do regime autoritário. Contundente e inovadora, já que radicalmente diversa, na retórica e nas demandas, do discurso típico do sindicalismo populista. Essa voz vinha do sindicato dos metalúrgicos de São Bernardo do Campo (SP), que representava um segmento expressivo da moderna classe operária brasileira: os trabalhadores das grandes empresas automobilísticas, que lideraram o "milagre econômico" brasileiro. Nascia aí o novo sindicalismo, também

129 Amaury de Souza, The nature of Corporati6t representation: leaders and members of organized labor in Brozo, Pil. D. thesis, MIT, Cambridge, Parte I, cap. IV e V, 1978, pp. 118-216. chamado sindicalismo autêntico.

Muito já se escreveu sobre a nova corrente sindical, que se originou no sindicato dos metalúrgicos de São Bernardo do Campo e por ele foi liderada. ${ }^{130}$

O cerne de sua proposta foi a abolição da ingerência estatal no mundo do trabalho, consagrada na própria legislação, que plasmara nosso sistema de relações trabalhistas, nos anos trinta e quarenta, e potenciada pelos governos autoritários. Desta forma, o novo sindicalismo em gestação opôs-se à política de fixação pelo governo dos reajustes anuais de salário e pregou a negociação coletiva entre sindicatos e empregadores, sem a mediação de organismos estatais. Para tomá-la possível exigiu a volta ao direito irrestrito de greve e a liberdade e autonomia sindicais, cerceadas pela legislação que impunha a tutela do Ministério do Trabalho entre as entidades de classe. Contra a lei que erigia os sindicatos fora das empresas,

130 Maria Hermínia Tavares de Almeida, "Sindicato no Brasil: novos problemas, velhas estruturas", Debate e Critica 6, jul., 1975, pp.49-74; "Desarrollo Capitalista y acción sindical", Revista Mexicana de Sociologia. 2/78, Ano XL, Vol. XL, abr.-jun. 1978, pp. 467-492; "Tendências recentes da negociação coletiva no Brasil", Dados 2, vol. 24,1981, pp.161-190; Leoncio Martins Rodrigues, "Tendências futuras do sindicalismo brasileiro", in Henrique Rattner (org.), Brasil 1990, caminho alternativo do desenvolvimento, São Paulo, Brasiliense, 1979, pp.121-142; José Álvaro Moisés, "Qual é a estratégia do novo sindicalismo?", Rio de Janeiro,ILDES, 1980, mimeo.; "O ciclo de greves do final dos anos setenta". São Paulo, CEDEC, 1979, mimeo.; Ricardo Antunes (org.), "Por um novo sindicalismo", Caderno de Debate 7, São Paulo, Brasiliense, 1980; John Humphrey, "Operários na indústria automobilística do Brasil: novas tendências do movimento trabalhista", Estudos CEBRAP, 23, 1979, pp.81164. 
defendeu a criação de organismos sindicais nos locais de trabalho. Finalmente, em oposição a um sindicato burocratizado, oligárquico e pouco representativo, propôs um sindicalismo mobilizador, participacionista e democrático.

Essas reivindicações afirmadas não apenas em aberto confronto com a política social e trabalhista do regime autoritário, mas, também, em ruptura com a prática do sindicalismo populista, ao qual se acusava de não haver aproveitado a maré favorável para romper as amarras que o subordinavam ao Estado.

O novo sindicalismo traduzia em demandas por maior autonomia o anseio profundo de afirmação de uma identidade operária, forjada na experiência do degredo político e de uma cidadania social de segunda classe, que convivia com o florescimento de uma sociedade de consumo. Seu lastro social foi um importante estrato da nova classe trabalhadora industrial, multiplicada pela expansão econômica vertiginosa, concentrada em grandes unidades de produção, jovem - e, portanto, sem a memória das derrotas passadas -, pouco escolarizada, mas bem informada, graças à própria difusão dos meios de comunicação de massa.

$\mathrm{Na}$ medida em que o processo de abertura política foi criando espaços de manifestação das demandas reprimidas pela ordem autoritária, as bandeiras dos autênticos, plantadas em São Bernardo, propagaram-se para 'outros setores do operariado moderno, mas não são dele. Sindicatos de trabalhadores na grande siderurgia, na indústria petrolífera, na petroquímica, na metal mecânica, e, também, na distribuição de energia elétrica, além de bancários, médicos, professores, transformaram o novo sindicalismo em uma tendência, que deu eixo e o tom ao movimento sindical, que despertava por volta de 1977.

Apesar de minoritário, em termos do número de entidades sindicais que aglutinava, o novo sindicalismo chegou a ser predominante no que respeita à definição dos temas e ênfases das plataformas do movimento sindical durante, pelo menos, três anos (1978-1980).

Esse foi, também, o período em que a oposição às políticas salarial e trabalhista do governo deixou de ser assunto privativo das novas lideranças sindicais para se transformar na motivação de milhares de trabalhadores, que ao arrepio da lei reconquistaram a greve como direito e como arma.

\section{O despertar: a maré grevista, significado e consequências}

Em 1978 e 1979, o mundo do trabalho foi sacudido por uma onda de greves de proporções inéditas no Brasil p6s-64. As Tabelas 6,7 e 8 reúnem algumas informações a respeito. ${ }^{131}$

131 As tabelas foram construídas com dados obtidos no arquivo da Editora Oboré, em levantamento feito pelo Departamento de Documentação (DEDOC) da Editora Abril S.A. e em pesquisa realizada sob minha supervisão nos jornais diários Folha de S. Paulo e $O$ Estado de S. Paulo, entre 1979 e 1981. A informação disponível é precária e imprecisa e não permite cálculos elementares, tais como número de grevistas/sobre número total de trabalhadores, horas/homem perdidas. Os motivos das paralisações 
O movimento, que começou em maio de 1978, seguiu um curso ascendente no ano seguinte, declinando a partir de 1980. Em 1981, experimentou ligeira retomada, que não chegou, porém, a configurar uma inflexão da tendência ao declínio das mobilizações.

Tabela 6

SETORES ATINGIDOS PELOS MOVIMENTOS GREVISTAS $1978-1981$

\begin{tabular}{|c|c|c|c|c|c|c|}
\hline Anos & $\mathrm{ti}$ & $\mathrm{tcc}$ & $\mathrm{tbs}$ & $\mathrm{acm}$ & outros & total \\
\hline 1978 & $\begin{array}{c}104 \\
(75,9 \%)\end{array}$ & $\begin{array}{c}8 \\
(5,8 \%)\end{array}$ & $\begin{array}{c}13 \\
(9,4 \%)\end{array}$ & $\begin{array}{c}8 \\
(5,8 \%)\end{array}$ & $\begin{array}{c}4 \\
2,9 \%\end{array}$ & $\begin{array}{c}137 \\
(100 \%)\end{array}$ \\
\hline 1979 & $\begin{array}{c}61 \\
(27,2 \%)\end{array}$ & $\begin{array}{c}15 \\
(6,7 \%)\end{array}$ & $\begin{array}{c}52 \\
(23,2 \%)\end{array}$ & $\begin{array}{c}66 \\
(29,4 \%)\end{array}$ & $\begin{array}{c}30 \\
(13,3 \%)\end{array}$ & $\begin{array}{c}224 \\
(100 \%)\end{array}$ \\
\hline 1980 & $\begin{array}{c}19 \\
(32,7 \%)\end{array}$ & $\begin{array}{c}4 \\
(6,9 \%)\end{array}$ & $\begin{array}{c}11 \\
(18,9 \%)\end{array}$ & $\begin{array}{c}20 \\
(34,4 \%)\end{array}$ & $\begin{array}{c}4 \\
6,9 \%\end{array}$ & $\begin{array}{c}58 \\
(100 \%)\end{array}$ \\
\hline 1981 & $\begin{array}{c}28 \\
(29,7 \%)\end{array}$ & $\begin{array}{c}5 \\
(5,3 \%)\end{array}$ & $\begin{array}{c}8 \\
(8,5 \%)\end{array}$ & $\begin{array}{c}42 \\
44,6 \%\end{array}$ & $\begin{array}{c}11 \\
(11,7 \%)\end{array}$ & $\begin{array}{c}94 \\
100 \%\end{array}$ \\
\hline
\end{tabular}

$\mathrm{ti}=$ trabalhadores industriais

tcc $=$ trabalhadores na construção civil

tbs $=$ trabalhadores de base em serviços

$\mathrm{acm}=$ assalariados de classe média (médicos, professores e bancários)

outros $=$ não assalariados (feirantes, motoristas de táxi, motoristas de caminhão).

A participação relativa dos distintos segmentos das classes trabalhadoras variou de ano a ano (Tabela 6).

As paralisações tiveram início no núcleo moderno do parque

nem sempre são registrados a contento, com a descriminação do elenco completo de demandas. Fica assim prejudicada a avaliação dos resultados concretos de cada movimento. industrial brasileiro (indústrias automobilística e metal mecânica dos arredores de São Paulo), onde ocorreram 75,9\% dos movimentos em 1978.

Em 1979, o movimento grevista espalhou-se para outras regiões do país e para fora do setor industrial, arrastando outros segmentos das classes trabalhadoras. De uma parte, explodiram em greve os mais postergados dentre os assalariados urbanos - como os peões da construção civil -, bem como setores ocupados em serviços urbanos vários, de escassa tradição de luta e reduzida experiência sindical prévia - como motoristas de ônibus, vigilantes de bancos etc. Assim, os trabalhadores de base no setor terciário e na construção civil foram responsáveis por quase $30 \%$ de todas as greves realizadas, em 1979, contra 27,2\% protagonizadas pelo operariado industrial. De outra parte, ganhou importância, inédita na história das lutas sindicais no país, a movimentação dos profissionais assalariados de "classe média", particularmente médicos e professores do serviço público.

Em 1980, o impulso grevista arrefeceu. A mobilização em descenso foi sustentada pelos assalariados de classe média $(34,4 \%$ das greves), seguidos pelos operários da indústria $(32,7 \%)$.

No ano seguinte, os mesmos setores mantiveram a atividade grevista, destacando-se uma vez mais os profissionais assalariados de classe média (44,6\% dos movimentos).

No que respeita ã amplitude dos movimentos, a análise das Tabelas 7 e 8 indica, com clareza, pautas diferentes para os operários industriais, quando comparados aos demais segmentos das camadas 
trabalhadoras urbanas.

Tabela 7

BRASIL - VARIAÇÃO DE AMPLITUDE DAS GREVES 1978-1981

\begin{tabular}{|c|c|c|c|c|c|}
\hline Amp & $\begin{array}{l}\text { Uma } \\
\text { empresa }\end{array}$ & $\begin{array}{l}\text { Grupo de } \\
\text { empresas }\end{array}$ & Categoria & $N / S$ & Total \\
\hline 1978 & $\begin{array}{c}119 \\
(86,8 \%)\end{array}$ & $\begin{array}{c}3 \\
(2,1 \%)\end{array}$ & $\begin{array}{c}15 \\
(10,9 \%)\end{array}$ & - & $\begin{array}{c}137 \\
(100 \%)\end{array}$ \\
\hline \multirow{2}{*}{$1979^{(1)}$} & $\begin{array}{l}\text { A } 80 \\
(35,7 \%)\end{array}$ & $\begin{array}{c}15 \\
(6,3 \%)\end{array}$ & $\begin{array}{c}124 \\
(55,8 \%)\end{array}$ & $\begin{array}{c}5 \\
2,2 \%\end{array}$ & $\begin{array}{c}224 \\
(100 \%)\end{array}$ \\
\hline & B 71 & 15 & 105 & - & 191 \\
\hline 1980 & $\begin{array}{c}25 \\
43,1 \%\end{array}$ & - & $\begin{array}{c}33 \\
(56,8 \%)\end{array}$ & - & $\begin{array}{c}58 \\
(100 \%)\end{array}$ \\
\hline 1981 & $\begin{array}{c}54 \\
(57,4 \%)\end{array}$ & - & $\begin{array}{c}40 \\
(42,5 \%)\end{array}$ & - & $\begin{array}{c}94 \\
(100 \%)\end{array}$ \\
\hline Total $^{(A)}$ & $\begin{array}{c}278 \\
(54,2 \%)\end{array}$ & $\begin{array}{c}18 \\
(3,5 \%)\end{array}$ & $\begin{array}{c}212 \\
41,3 \%\end{array}$ & $\begin{array}{c}5 \\
1 \%\end{array}$ & $\begin{array}{c}513 \\
(100 \%)\end{array}$ \\
\hline Total $^{(B)}$ & $\begin{array}{c}269 \\
(56,0 \%)\end{array}$ & $\begin{array}{c}18 \\
(3,7 \%)\end{array}$ & $\begin{array}{c}193 \\
(40,2 \%)\end{array}$ & - & $\begin{array}{c}480 \\
(100 \%)\end{array}$ \\
\hline
\end{tabular}

OBS.: (1) - A 12 meses

$B$ exclusive meses setembro e outubro

Com efeito, ao longo do período analisado, as paralisações por empresa constituíram a forma por excelência da mobilização dos trabalhadores industriais, enquanto que as greves por categorias predominaram entre os trabalhadores de base em serviços, os assalariados de classe média e os outros setores.
Tabela 8

BRASIL - VARIAÇÃO DE AMPLITUDE DAS GREVES SEGUNDO SETORES DE TRABALHADORES ATINGIDOS 1978-1981

\begin{tabular}{|c|c|c|c|c|c|c|}
\hline Amplitude & $\mathrm{ti}$ & tcc & tbs & $\mathrm{acm}$ & outros & total \\
\hline Uma empresa & $\begin{array}{c}165 \\
81,6 \% \\
61,3 \%\end{array}$ & $\begin{array}{c}17 \\
56,6 \% \\
6,3 \%\end{array}$ & $\begin{array}{c}28 \\
37,8 \% \\
10,4 \%\end{array}$ & $\begin{array}{c}55 \\
45,4 \% \\
20,4 \%\end{array}$ & $\begin{array}{c}4 \\
7,5 \% \\
1,5 \%\end{array}$ & $\begin{array}{c}269 \\
56,0 \% \\
100 \%\end{array}$ \\
\hline Grupo de empresas & $\begin{array}{c}8 \\
4,0 \% \\
44,4 \%\end{array}$ & $\begin{array}{c}3 \\
10 \% \\
16,6 \%\end{array}$ & $\begin{array}{c}4 \\
5,4 \% \\
22,2 \%\end{array}$ & $\begin{array}{c}3 \\
2,4 \% \\
16,6 \%\end{array}$ & $\begin{array}{l}0 \\
- \\
-\end{array}$ & $\begin{array}{c}18 \\
3,7 \% \\
100 \%\end{array}$ \\
\hline Categoria & $\begin{array}{c}29 \\
14,3 \% \\
15,0 \%\end{array}$ & $\begin{array}{c}10 \\
33,3 \% \\
5,1 \%\end{array}$ & $\begin{array}{c}42 \\
56,7 \% \\
21,7 \%\end{array}$ & $\begin{array}{c}63 \\
52,0 \% \\
32,6 \%\end{array}$ & $\begin{array}{c}49 \\
92,4 \% \\
25,3 \%\end{array}$ & $\begin{array}{c}193 \\
40,2 \% \\
100 \%\end{array}$ \\
\hline Total & $\begin{array}{c}202 \\
100 \% \\
42,1 \%\end{array}$ & $\begin{array}{c}30 \\
100 \% \\
6,3 \%\end{array}$ & $\begin{array}{c}74 \\
100 \% \\
15,4 \%\end{array}$ & $\begin{array}{c}121 \\
100 \% \\
25,2 \%\end{array}$ & $\begin{array}{c}53 \\
100 \% \\
11 \%\end{array}$ & $\begin{array}{c}480 \\
100 \% \\
100 \%\end{array}$ \\
\hline
\end{tabular}

Para o período como um todo, $81,6 \%$ das paralisações realizadas pelos trabalhadores industriais limitaram-se ao âmbito de uma empresa e $61,3 \%$ deste tipo de greve foram de sua responsabilidade. Ano a ano, as porcentagens de greves por empresa empreendidas - pelo operariado fabril variaram muito. Mas somente em 1980, foram superadas pelos movimentos abarcando a categoria profissional (63,1\% contra $36,8 \%$ de paralisações por empresa). Em 1978, perfizeram 92,3\% da atividade grevista dos trabalhadores na indústria, contra 72,5\% em 1979 e 89,2\% em 1981.

Não se tem elementos para afirmar com precisão o peso dos movimentos nas grandes indústrias modernas sobre o total das 
paredes por empresa. Entretanto, a desagregação dos movimentos por região e apenas para as categorias de metalúrgicos revela uma ponderável incidência de greves por empresa, em áreas onde os grandes estabelecimentos do setor metal mecânico e automobilístico marcam o perfil do parque industrial.

A evidência de apenas quatro anos de atividade grevista não autoriza conclusões taxativas. Todavia, é plausível afirmar a existência de uma tendência persistente a movimentos por empresa no setor industrial moderno, bem mais acentuada do que para os outros setores ocupacionais urbanos. Essa tendência, de resto, implica uma nova pauta de- ação coletiva diversa da que predominou no período do sindicalismo populista, onde a greve por categoria profissional constituiu a moda e o modelo.

O auge do movimento grevista, em 1979, significou a convergência e unificação dos segmentos das classes trabalhadoras, com vivências, problemas e aspirações diferenciados.

Para além da diversidade de posições no mercado de trabalho, de condições de trabalho e de vida, de prática sindical ou de traquejo político, identificava-os a experiência comum da exclusão social e política sob o regime autoritário. O fim da política salarial, praticada desde 1965, foi a grande reivindicação explícita dos trabalhadores, cuja mobilização, em si mesma, afirmava, também, o direito à greve e à autonomia dos sindicatos frente ao governo.

Entretanto, havia algo mais, uma demanda latente que constituía o movimento trabalhador em ator coletivo unificado em oposição ao autoritarismo: o reconhecimento da dignidade da condição operária no âmbito da sociedade e da igualdade cidadã na arena política.

Neste processo de constituição de uma nova identidade coletiva, o operariado da grande indústria moderna tomou-se símbolo da autonomia e autodeterminação das classes trabalhadoras, e a figura mais expressiva do novo sindicalismo - Lula — transformouse em líder nacional dos trabalhadores.

A identificação no plano político e simbólico não eliminou, porém, as diferenças existentes entre os diversos setores assalariados. E o resultado de sua mobilização conjunta teve efeitos contraditórios sobre a organização sindical e sobre todo o sistema de relações trabalhistas com forte ingerência estatal, moldado pela legislação de 1942.

Desde seu aparecimento, o novo sindicalismo pregara uma nova institucionalidade, com sindicatos libertos do controle estatal, presentes, nos locais de trabalho e contratando diretamente com o patronato, sem intermediários e mediadores governamentais. Pregara, também, um sindicalismo democrático, que permitisse ampla participação de massas.

As primeiras greves, que paralisaram o núcleo moderno do parque industrial, em 1978, pareciam abrir caminho para a mudança radical das instituições e das práticas de negociação. Foram movimentos por empresa, solucionados através de acordos diretos entre patronato e sindicatos, rompendo com uma tradição de greves por categoria cujo desenlace passava por uma negociação triangular 
envolvendo sindicatos patronais e operários, sob a mediação do Ministério do Trabalho e a arbitragem da Justiça do Trabalho.

Aberta a brecha, nos dois anos seguintes, a vanguarda do sindicalismo autêntico — os operários da indústria automobilística paulista tentou deitar por terra o velho edifício das instituições trabalhistas, usando a força da greve de massas, com a participação ativa e decidida de seus cento e vinte mil trabalhadores e a simpatia do conjunto dos assalariados.

Em defesa da ordem estabelecida, o governo usou os instrumentos proporcionados pela legislação trabalhista, que lhe permitiam intervir, controlar e submeter os sindicatos. A liderança do operariado moderno foi afastada de seus postos, encerrando prematuramente a experiência de um sindicalismo democrático de participação de massas.

Entretanto, ainda que em ritmo menor, persistiram as greves por empresa no setor industrial e, particularmente, no parque automobilístico, a indicar a profundidade do fenômeno do novo sindicalismo, que deitava raízes na contestação da condição operária concretamente vivida no interior da grande empresa moderna.

A descentralização da atividade grevista da categoria para a empresa começou a sedimentar procedimentos mais ou menos informais de negociação direta e deu origem às primeiras experiências de comissões de representantes de trabalhadores, reconhecidas pelo patronato como interlocutores válidos, nas principais montadoras de automóveis (Volkswagen, Ford, Scania) ${ }^{132}$.

Em resumo, enfrentando a repressão governamental, o novo sindicalismo viu fracassar sua tentativa de promover a alteração radical da estrutura sindical e dos procedimentos de negociação vigentes, através da pressão das massas mobilizadas. Todavia, por meio de uma ação coletiva menos heróica, mas eficaz em sua persistência - a greve localizada -, acabou por criar novos espaços de negociação direta e descentralizada e formas de organização na base, que poderão alterar o funcionamento dos sindicatos burocratizados e distantes do mundo fabril, pelo menos no coração do parque industrial brasileiro.

Todavia, a sobrevivência da velha institucionalidade trabalhista não se explica apenas pela força da política governamental e pela derrota da estratégia de massas dos autênticos. No rebojo da maré grevista, a entrada em cena de novos segmentos das classes trabalhadoras teve efeitos paradoxais.

O alastramento das greves, até transformar-se em movimento do conjunto dos assalariados urbanos, foi sem dúvida decisivo para forçar a mudança da política salarial, depois de inabaláveis quinze

132 As tentativas de organização nos locais de trabalho pontilham toda a história do movimento sindical brasileiro, via de regra, na forma de comissões de greve ou de organizações de base servindo de apoio a tendências de oposição sindical. Seu fracasso em institucionalizar-se indica a inexistência, por razões várias, de procedimento de barganha coletiva a nível de empresa. Sua reiteração, apesar dos fracassos prévios, denuncia as limitações dos sindicatos municipais distanciados do mundo do trabalho. 
anos de existência. Foi, também, fundamental para afirmar o direito à greve e à liberdade de movimentação sindical, muito além do que a legislação os permite. Foi decisivo, por último, para impor a presença dos trabalhadores na arena política, onde se decide a sorte do regime político, que sucederá o autoritarismo burocrático em crise.

Teve, porém, seus efeitos perversos ao dar nova atualidade a direitos, formas de mobilização e de organização, que para o operariado moderno já eram anacrônicos e demandavam mudança radical. Para os operários da construção civil, assim como para outros setores desprivilegiados no mercado de trabalho, o simples cumprimento da legislação trabalhista constituía motivo suficiente para ação coletiva. Por outras razões, a conquista dos direitos sociais e sindicais mínimos esteve e está no centro das lutas dos assalariados de classe média do setor público, cuja importância na luta grevista já foi destacada.

O mesmo se poderá dizer dos trabalhadores rurais, cujas lutas, pouco estudadas, dão-se ainda em torno do respeito aos direitos, que, de há muito legalmente assegurados aos trabalhadores urbanos, só no período recente lhes foram estendidos.

Essa diversidade inevitável de demandas, experiência sindical prévia e formas de ação coletiva não explica direta e imediatamente que, ao contrário do que muitos esperavam, não tenham sido tão dramáticas as mudanças na organização sindical, nas formas de negociação e no ordenamento legal que as estrutura em um sistema de relações profissionais fortemente estatista.
A heterogeneidade das classes trabalhadoras. proporcionou, porém, suporte e condições de viabilidade para dois tipos de políticas conservadoras: a do governo e a de uma parte das lideranças sindicais.

\section{As políticas sindicais: conservação e mudança}

Em outras ocasiões tratei de caracterizar a resposta governamental a reativação do movimento sindical, por meio de políticas que chamei de reforma conservadora ${ }^{133}$.

Todavia, o conservadorismo não constituiu apanágio do governo militar da abertura. Uma inclinação conservadora marcou a conduta da imensa maioria das lideranças sindicais, afeitas e comprometidas com o ramerrão burocrático, dominante ao longo de quase uma década de desmobilização. No caso, não se tratava tanto de uma ideologia política conservadora, mas de um modo de enfrentar a rotina sindical e de um compromisso com a defesa de instituições, cuja existência permitia a um imenso contingente de dirigentes espalhados pela maioria dos 4671 sindicatos, 159 federações e 21 confederações $^{134}$ ter uma carreira modesta, mas de futuro assegurado.

Essa prática conservadora não excluía, conforme as

133 Maria Hermínia Tavares de Almeida, "Tendências recentes da negociação coletiva no Brasil", idem, ibidem.

134 Dados oficiais do" Ministério do Trabalho até 2S de maio de 1981. Cf Luiz Roberto Serrano, "Em busca de definições", ISTO É, 26.8.1981, p. 71. 
circunstâncias, o discurso radical contra a política trabalhista do governo e os males da falta de liberdade e autonomia sindicais. Afinal, ela era conservação de um establishment sindical, que desde os anos quarenta convivera com diferentes regimes, distintas orientações governamentais e diversos níveis de movimentação social.

Neste contesto de conservadorismo prático, de resistência passiva a mudanças drásticas do ordenamento jurídico e do funcionamento concreto da estrutura sindical, moveram-se tendências, que foram adquirindo maior visibilidade no final dos anos setenta.

Menezes e Sarti ${ }^{135}$ apontam três linhas de atuação, já visíveis em 1978 e que se distinguem pela oposição mais ou menos radical à estrutura sindical oficial.

A primeira foi a dos grupos auto-intitulados oposições sindicais, constituídos por militantes católicos e por remanescentes de pequenos agrupamentos à esquerda dos comunistas. Com uma atuação pouco expressiva mas, praticamente ininterrupta, desde 1966-67, empenharam-se, sem éxito, na construção de uma rede sindical paralela à estrutura oficial, a partir da organização de comissões nas empresas.

A segunda foi encarnada pelos expoentes do novo

135 Clarice Melamed Menezes e Ingrid Sarti, CONCLAT 1981, Campinas, Cartograf, 1981. sindicalismo, corrente que surge dentro dos sindicatos oficiais, sem vinculações com as "oposições sindicais" e alheias à influência ideológica e política de qualquer dos agrupamentos da esquerda marxista. Nos propósitos e na prática concreta, esta linha de atuação se voltou à transformação radical do arcabouço sindical e de todo o sistema de relações trabalhistas.

A terceira linha de atuação, defendida pela esquerda ortodoxa (comunistas), apesar de fazer suas as críticas e proposições dos autênticos, em nome de uma política de junção de forças, passou a advogar o não rompimento com o establishment sindical conservador e, por conseguinte, a aceitação de um ritmo mais lento de mudança das instituições sindicais e trabalhistas. No início muito próxima das lideranças do novo sindicalismo, essa corrente dela foi se afastando a partir do momento em que a ebulição grevista tomou possível passar de uma retórica de oposição a ações concretas encaminhadas a transformar a organização sindical e as práticas de negociação.

Assim, no início de 1980, o movimento sindical urbano gravitava em tomo de dois grandes blocos, de composição interna bastante heterogênea. De um lado, situavam-se as forças do novo sindicalismo, em conjunção, nem sempre tranqüila, com as chamadas oposições sindicais. De outro, agrupavam-se as lideranças sindicais influídas pela esquerda ortodoxa e uma plêiade de dirigentes comprometidos com o status qual sindical, constituindo a autodenominada Unidade Sindical.

A polêmica e a disputa entre as duas forças deu o tom e a 
dinâmica do movimento sindical. Sobretudo, quando a mobilização de massas refluiu e a atividade sindical passou a ser assunto de uma parcela não muito numerosa de dirigentes e ativistas freqüentadores das sedes de sindicato.

As divergências ganharam seu momento privilegiado de expressão nas eleições para renovação das diretorias de sindicatos. Assim, de 18 pleitos sindicais, noticiados pela grande imprensa, entre outubro de 1979 e agosto de 1981, registrou-se apenas um caso em que se apresentou chapa única. Onze vezes Unidade Sindical e novo sindicalismo e/ou oposições sindicais se enfrentaram. Em duas oportunidades Unidade Sindical disputou com lideranças conservadoras e, em quatro oportunidades, forças de oposição se unificaram contra chapas situacionistas. A Unidade Sindical obteve nove vitórias contra três das Oposições sindicais e/ou novo sindicalismo.

É difícil avaliar a força de cada um dos blocos, mesmo porque continuou numeroso o contingente de sindicatos não comprometidos em definitivo com qualquer dos dois. A Unidade Sindical certamente conta com um grupo mais numeroso de entidades associativas. Entretanto, a capacidade de influência política dos dois blocos sobre a parcela ativa do movimento sindical parece equivaler-se.

Com efeito, na I Conferência Nacional das Classes Trabalhadoras (CONCLAT), em agosto de 1981, a Unidade Sindical e o novo sindicalismo contavam praticamente com a mesma quantidade de votos, sendo forçados a buscar soluções de compromisso. Por outro lado, uma pesquisa de opinião, realizada durante a reunião, indicou que 46,5\% dos trabalhadores entrevistados consideravam Lula, dirigente máximo do novo sindicalismo, a figura que mais se aproximava do modelo ideal de líder sindical. Apenas 9\% apontaram o nome do principal articulador da "Unidade Sindical. ${ }^{136}$

A crescente polarização do sindicalismo não expressou apenas diferenças de estratégia sindical. Progressivamente, elas passaram a refletir distintas opções político-partidárias, em uma conjuntura de reorganização do sistema de partidos no Brasil, aberta com a promulgação da legislação, que, em novembro de 1979, extingui as duas agremiações existentes - ARENA e MDB - e traçou as normas para a estruturação de novos partidos.

As lideranças do novo sindicalismo lançaram-se de corpo e alma à organização do Partido dos Trabalhadores (PT), enquanto que os dirigentes da Unidade Sindical procuraram levar seus seguidores para a agremiação que recolheu as tradições e a maioria dos membros do antigo partido único oposicionista, agora chamado PMDB.

A partidarização das lideranças sindicais mais expressivas coincidiu com a retração da atividade grevista e com um quadro de dificuldades econômicas. crescentes, acentuadas por uma política

136A pesquisa foi realizada pela revista semanal ISTO É, por meio da aplicação de questionários a uma amostra aleatória de 232 casos em um universo de 5036 trabalhadores, apud "A visão sindical", ISTOE, 2.9. 1981, pp. 24-25. 
econômica recessiva, que afetou negativamente o mercado de trabalho.

Nestas condições a disputa no movimento sindical acirrou-se e subordinou-se à lógica da concorrência entre partidos em formação, a despeito das constantes declarações de todos a favor da autonomia dos organismos de massa em relação aos partidos.

A pesquisa realizada durante a I CONCLAT, mencionada anteriormente, mostrou que 59\% dos participantes eram filiados a partidos, contra $41 \%$ não filiados. Dos primeiros, $54 \%$ pertenciam ao PT, 35\% ao PMDB, 5,5\% aos três outros partidos de oposição (PP, PTB e PDT) e apenas $1 \%$ ao partido do governo, PDS. Entre os não miados, 44\% acreditavam que o PMDB atendia melhor aos interesses dos trabalhadores, contra $31 \%$ de respostas dadas ao PT. ${ }^{137}$

\section{Arriscando conclusões}

É difícil e arriscado fazer prognósticos sobre um processo em curso. Entretanto, tudo parece indicar que não são previsíveis mudanças dramáticas do sistema de relações trabalhistas fortemente marcado pela presença do Estado.

A comoção provocada pela maré grevista não foi suficiente para deitar por terra uma ordem institucional antiga e que até hoje conta com muitos defensores abertos ou velados no governo, no aparelho de Estado, entre o empresariado, e, sobretudo, entre os

137 Idem, ibidem, p. 25. próprios sindicalistas.

O sopro renovador do novo sindicalismo não foi forte $o$ suficiente parar criar uma nova ordem, na qual o Estado não fosse força ativa e sindicatos autônomos, democráticos e representativos pudessem afirmar-se no jogo livre da negociação coletiva. Todavia, marcou definitivamente o movimento sindical brasileiro com as imagens de um sindicalismo de participação de massas, democrático nos projetos e procedimentos. Para além de sua força simbólica abriu um espaço real de organização e livre contratação nas empresas.

Depois de tudo, convivem hoje, no sistema brasileiro de relações trabalhistas, procedimentos antigos e cristalizados de negociação centralizada e triangular e formas novas de negociação descentralizada e direta, em processo de institucionalização. Distante de um jogo de soma zero, é possível que as relações trabalhistas comportem a existência — e mesmo o crescimento — simultâneos da ingerência estatal e dos espaços de livres confronto e entendimento direto entre patronato e trabalhadores.

De outra parte, é ainda muito cedo para prever como se desenvolverão as relações entre movimento sindical e partidos políticos de oposição, possível que o estreitamento das margens de manobra no terreno social, em virtude das vicissitudes atuais do mercado de trabalho, tenda a ser contrabalançado por uma atuação mais decidida na arena política e parlamentar por intermédio dos partidos políticos.

No passado, o sindicalismo brasileiro fez política utilizando 
seus espaços de representação corporativista no aparelho de Estado e sua proximidade, com ministros do Trabalho, vice-presidentes e presidentes da República. Este não parece ser o caminho mais livre e curto hoje em dia. Um certo distanciamento com relação ao Executivo talvez conduza a privilegiamento, da atuação política através dos partidos.Uma coisa é certa: pelo menos por algum tempo, os rumos do movimento sindical não se definirão com independência dos partidos políticos.

Uma coisa é certa: pelo menos por algum tempo, os rumos do movimento sindical não se definirão com independência dos partidos políticos.

\section{Movimentos sociais urbanos: balanço crítico}

\section{Ruth Cardoso}

Quando começaram os estudos sobre os movimentos sociais urbanos, eles foram uma rajada de ar fresco em nossa produção sociológica. O conhecimento sobre as classes populares não havia acompanhado as transformações por que passara nossa sociedade. Não que as ciências sociais latino-americanas estivessem esclerosadas. Pelo contrário, durante os anos 60, dois temas marcaram a sua presença no contexto intelectual internacional: a marginalidade e a dependência. Estes estudos enfatizaram as especificidades do desenvolvimento latino-americano e criaram um novo quadro teórico para analisar o processo da industrialização periférica.

A discussão do tema da marginalidade social, em suas várias vertentes, propunha a imagem de sociedades divididas, onde a ruptura entre os excluídos do moderno sistema capitalista e os nele integrados parecia indicar a presença de uma nova contradição estrutural, capaz de gerar um movimento transformador na periferia do mundo capitalista. A rebelião das massas marginais, que levaria de roldão as formas de dominação baseadas em um sistema produtivo excludente, passou a ser uma esperança alimentada (ainda que nem sempre explicitada) pelos cientistas sociais. Sob esta forma, as ciências sociais respondiam à descrença crescente nos modelos 
explicativos vigentes nos anos 50 e que viam na forma clássica de luta entre as classes fundamentais (burguesia e proletariado) o único e necessário caminho de transformação. Porém, o desencanto com o novo esquema também não tardou, pois as "massas marginais" não assumiam seu papel histórico; tal como o proletariado, deixaram de cumprir sua esperada função.

Em vez de um capitalismo excludente e de cidades mais inchadas por um terciário miserável, os anos 70 trouxeram à cena (pelo menos em alguns países) uma camada popular mais participante. Setores sociais tradicionalmente excluídos da política passaram a se organizar para reivindicar maior igualdade, sentindo-se parte deste sistema político, embora sua parte mais fraca. Nenhuma crescente exclusão era visível e não aumentava a distância entre os "marginalizados" e os "integrados". E isto ocorria, pelo menos em alguns países da América Latina, em condições especialmente difíceis. Durante este período, instalaram-se regimes militares que, rompendo abruptamente com os sistemas político-democráticos, proscreveram todas as organizações ligadas às classes populares. Apesar deste contexto tão negativo de reorganização do Estado e da sociedade, passado o período de maior repressão assistimos a uma revitalização das manifestações da vontade popular.

É quando passam a ocupar a atenção dos sociólogos os movimentos sociais urbanos e rurais e todas as organizações que mostram uma sociedade civil em movimento. Estimulados pela visibilidade da presença popular, os estudos começaram a se multiplicar. Entretanto, faltavam referências teóricas úteis para explicar estas novas formas de participação política, e a inspiração veio com a produção mais recente nos países centrais, onde também se redescobria a problemática urbana.

Será difícil encontrarmos entre os autores que tratam de movimentos sociais ou organizações populares no Brasil alguém que não utilize como orientação teórica básica as obras de Castells, Borja, Lojkine, para só citar alguns dos inspiradores ${ }^{1}$. Estes autores começavam a abrir um debate inovador. Discutiam como a luta de classe se desdobrava, no mundo contemporâneo, em lutas urbanas e como, na fase atual do capitalismo, as manifestações libertárias (que a. esquerda tinha tanta dificuldade em absorver) eram uma nova face do povo, que recusava a disciplina produtiva e reivindicava o direito a uma vida melhor.

É preciso não esquecer, entretanto, que estes autores que colocavam em evidência as chamadas "novas contradições urbanas" tinham como pano de fundo as manifestações que sacudiram as sociedades desenvolvidas durante a década de 60. Os negros, as mulheres, os estudantes em maio de 68 e as comunidades hippies ou os objetores de consciência eram setores que se auto definiam como marginais à sociedade industrial e propunham um novo modo de

1 Jacobi em sua resenha bibliográfica sobre movimentos sociais urbanos no Brasil nos oferece um apanhado geral sobre estes estudos e indica também estes autores como as principais fontes teóricas utilizadas. (Bib., n.9, 1980, p.22). 
vida.

É ainda o rumor dessas manifestações libertárias que parece estar ouvindo Castells quando abre seu livro Luttes Urbaines com a seguinte frase:

De repente, o rumor surdo e regular da circulação urbana foi quebrado por uma confusão de passos, vozes, gritos, barulhos de metal e vidro. O fluxo dos automóveis parou, grupos se formam, a massa em movimento cresce, pedaços de pano, de papel, de madeira falam deles. E de sua cidade. Em frente, os eternos capacetes, a ordem, o passo cadenciado, e logo a carga, a violência, a recusa. Algumas vezes o gás, outras o sangue ou ainda o disparar de uma arma de fogo. Sempre, sob estas diversas formas, o choque. Entre os que falam de si mesmos e aqueles que falam dos que dão as ordens. Entre os que querem mudar a vida e aqueles que querem restabelecer este rumor surdo da circulação regular ao ritmo cotidiano das coisas que passam sem passar (Castells, 1975, p.6).

Não cabe dúvida ainda o participante de 68 que está procurando entender e explicar esta nova sociedade cuja disciplina ordena tudo mas não pode conter a revolta da contracultura e dos anti-sistema. O desafio é analisar o potencial transformador desses novos fenômenos políticos porque neles:

Se misturam as novas contradições sociais e o escotismo, a recusa das novas formas de opressão e o passadismo, a luta revolucionária e a defesa da vizinhança. Em todos os casos quando, dia após dia, em todos os países vemos aumentar o número, a dimensão e a intensidade das mobilizações populares ligadas à qualidade de vida cotidiana, parece lógico concluir pela emergência de uma forma de conflito social, diretamente ligada à organização coletiva do modo de vida (Castells, 1975, p.7).

Este trecho propõe que seja repensado o lugar dos problemas urbanos e que se procure neles a projeção dos conflitos de classes.

Trata-se de uma nova postura teórica, bastante estimulante quando aplicada a uma realidade latino-americana. Mas para utilizá-la com proveito é preciso não esquecer que a noção de "contradições urbanas" resulta das características próprias da gestão estatal no capitalismo monopolista.

Quando Castells define sua problemática teórica e seus instrumentos conceituais de trabalho (Castells, 1974), ele nos fala de consumo coletivo, classes sociais e processos políticos no capitalismo avançado. Lojkine, para criticar Castells, dedica.se especialmente a analisar as características e o papel do Estado moderno e suas relações com as diferentes classes (Lojkine, 1977). Não é preciso ir mais longe para aceitar que o conceito de "contradições urbanas" foi elaborado a partir da constatação de que o Estado tem um corpo novo nos países avançados, e que suas peculiares relações com a sociedade geram processos políticos específicos. Neste sentido, Touraine foi o mais arrojado entre os que escreveram sobre movimentos sociais. Sua análise tem como base a constatação de que vivemos em uma sociedade pós-industrial (ou sociedade programada, como ele prefere chamar) onde o Estado tem novas formas de gestão e onde os movimentos sociais são os atores principais e o lugar do conflito (Touraine, 1978).

$\mathrm{Na}$ medida em que nos afastamos do centro em direção à periferia, vemos que a bibliografia passa a desconsiderar progressivamente a análise específica das funções do Estado, 
permanecendo apenas com o seu caráter disciplinar e autoritário como um pano de fundo em que se projetam as análises concretas. No livro de Borja, sobre a Espanha, o Estado já é um personagem bastante mais indiferenciado e, quando se chega nos estudos sobre a América Latina, sua figura está presente na interpretação, mas desenhada apenas em seus contornos mais gerais.

Isto ocorre por várias razões. A primeira delas é que estas manifestações populares têm início em contextos políticos repressivos e por isso mesmo são recebidas como demonstrações da força latente das classes subalternas. É deste ângulo que serão analisados e, a partir daí, seu visível caráter antigoverno é muitas vezes confundido com uma crítica radical ao sistema político. E como as reivindicações colocam frente a frente setores populares e aparelhos do Estado, a maioria das interpretações, como indica Jacobi, identificam neste confronto um novo caminho político:

O cerne da questão está no confronto dos movimentos sociais urbanos com o Poder Público; na politização dos conflitos, permitindo a emergência de uma perspectiva que ultrapassa a dimensão econômico-corporativa atingindo a esfera política. Discute-se a representatividade do Poder Público que se afirma capaz mas não consegue responder ao Estado. O antagonismo ao Estado cria as condições para a unidade dos seus protagonistas, acelerando o desenvolvimento de uma força social que vai adquirindo uma dinâmica própria (Jacobi, 1980, p.24).

Decretar o nascimento de novos atores políticos, portadores de uma força transformadora, sem que a análise demonstre concretamente a novidade de seu papel mediador entre a sociedade civil e o Estado, parece incompleto. A simples existência empírica de manifestações populares não autoriza conclusões a respeito de sua função política, pois elas estão referidas a um contexto que precisa ser descrito. Falta um mapeamento das diferenças entre os vários movimentos sociais; das condições de sua eficácia e dos contextos políticos nas quais emergem. O processo de mobilização popular aparece, nestas interpretações, como resposta espontânea ao autoritarismo e à incompetência dos governos. Neste quadro, a atenção dos cientistas se volta para este sentimento "oposicionistademocrático" das massas urbanas e deixa na sombra a atuação do Estado.

A segunda razão pela qual não se percebe a ação do Estado diz respeito ao modo de definir os movimentos sociais como objeto de estudo. $\mathrm{O}$ interesse por estes fenômenos surgiu, como já vimos, no contexto de sociedades latino-americanas que viviam um processo de desenvolvimento industrial acelerado e nas quais o sistema político, por razões diversas, não apresentava as características usuais das democracias parlamentares. Note-se que as manifestações que geraram maior número de estudos tiveram lugar em países como o Peru, México e Brasil, nos quais, apesar de os sistemas de governo serem muito diferentes, havia aspectos comuns quanto ao agigantamento do Estado e à centralização administrativa ${ }^{2}$.

2 Excluí desta lista o Chile - apesar de que os estudos pioneiros nesta direção foram feitos nesse país - porque acredito que as diferenças de 
Estas semelhanças colaboram para mascarar as diferenças de sistema político tanto entre estes países quanto entre as nações periféricas e as centrais. Enquanto que os teóricos franceses, nossos inspiradores, falavam da mudança qualitativa das funções do Estado sob o capitalismo monopólico, nós, latino-americanos, para explicar fenômenos semelhantes, nos fixamos na crítica ao autoritarismo de nossos governos, deixando de lado as transformações substantivas do aparelho de Estado. Duas ordens de problemas aparecem, por isso, sobrepostas:

1) transformação do papel econômico do Estado e a conseqüente centralização de decisões;

2) governo autoritário e repressão das formas tradicionais de expressão e reivindicação populares.

É certo que nas nações em desenvolvimento houve um processo de centralização e hiperdesenvolvimento do Estado, que ocorreu concomitantemente à reforma administrativa e agilização dos serviços públicos. Os nossos movimentos reivindicativos surgem em resposta a estes dois processos. Seus intérpretes, entretanto, privilegiaram a rebeldia das massas contra o autoritarismo (que é real) mas deixaram de lado que as administrações mais modernas e os planejadores mais eficientes dialogam com os usuários e consumidores de serviços estatais. Ficou desconsiderada a

contexto político são suficientemente grandes para explicar diferenças de interpretação quanto ao papel do Estado. O jogo partidário, então vigente, dava uma dinâmica diversa aos movimentos sociais. semelhança e concomitância das formas de protesto contra planos urbanísticos que ocorrem aqui e em outros países democráticos.

O personagem "Estado" entrou neste novo cenário com uma caracterização um pouco pobre, definido apenas como inimigo autoritário ou a mira contra o qual se movia a sociedade civil. Esta sim, foi descrita como diversificada, conflitiva, dinâmica e espontânea, enquanto a mudança nos métodos de trabalho de alguns setores governamentais ficou esquecida.

Há pouca discordância na interpretação dos movimentos e associações populares. Os pressupostos, nem sempre explícitos, que guiaram os interesses por estas novas formas de participação têm suas raízes no desamparo teórico com que enfrentamos as vitórias do autoritarismo nos países latino-americanos. No Brasil, os estudos sobre o populismo se tornaram importantes depois de 1964, quando teve início nossa mais recente experiência de governos autoritários e antipopulares. Foi o desejo de compreender os impasses e as derrotas da democracia tal como era praticada que trouxe à baila uma visão crítica do período intermediário entre o Estado Novo e o regime militar atual. Foi olhando para trás que o tema da eterna exclusão das classes populares tomou corpo e forneceu o ponto de partida para interpretar sua nova presença. A desilusão com os últimos governos mobilizadores e o inesperado sucesso do golpe de 1964 recolocaram em pauta os temas da democracia e da participação-cooptação dos trabalhadores.

O livro de Weffort O Populismo na Política Brasileira 
(Weffort, 1978) coloca juntos ensaios escritos desde 1963 e discute a natureza ambígua dos vários populismos. Nestes sistemas, ao mesmo tempo em que as classes populares marcam sua presença e exigem concessões, encontram limites à sua participação plena que são dados por sua subordinação a setores da elite. Já no seu primeiro ensaio Weffort afirma que:

\begin{abstract}
o populismo implica, em qualquer de suas formas, uma traição à massa popular. Ainda quando tenha bases operárias mais ou menos amplas como no caso de Vargas e de Quadros, o padrão típico da política permanece limitado aos horizontes da pequena burguesia (Weffort, 1978, p.34).
\end{abstract}

A crise da democracia populista aparece como uma crise estrutural, e sua superação só pode ocorrer através de mudanças profundas do sistema produtivo. As classes populares não terão lugar na política e serão manipuladas enquanto não puderem expressar seus interesses autonomamente. Se a classe operária e os demais trabalhadores foram o sustentáculo de populismos traidores, e se os sistemas eleitorais estavam baseados na manipulação, a participação ficou deslegitimada como forma de ação política.

Entretanto, a década de 70 trará surpresas.

Esta mesma massa que enchia os comícios populares parece ter-se guardado para reaparecer "espontaneamente" nas associações de bairro após 10 anos de autoritarismo.

$\mathrm{E}$, quase todos os autores, preocupados com o presente, valorizam a autonomia e procuram mostrar que estamos diante de fenômenos novos que pouco devem à fase populista já morta. No quadro destes estudos, o trabalho de Moisés (1978) faz exceção, porque seu interesse pioneiro pelas associações de bairro levou-o a uma pesquisa sobre movimentos autonomistas que ocorreram nos anos 50. Entretanto, trabalhando com o contexto da política populista, este autor retoma como premissas analíticas as conclusões de Weffort:

1) As instâncias políticas destinadas a representar os interesses populares (partidos, sindicatos etc.) não atuavam com autonomia e estavam subordinadas ao jogo dos grupos dominantes e das camadas médias;

2) $\mathrm{O}$ populismo, ao mesmo tempo que atendia algumas demandas populares, continha seus desejos de aumentar seu espaço de representação.

Para Moisés, essas premissas são importantes porque seu esforço vai no sentido de demonstrara continuidade que liga os movimentos urbanos no passado e no presente, atribuindo a eles força e sentido histórico.

Para estes dois autores, a pouca importância dada às agremiações de moradores e o desconhecimento das lutas locais se devem às mesmas razões que levaram os analistas de esquerda a não compreender a força das lideranças populistas. Algumas vezes estes líderes foram sensíveis às reivindicações populares, enquanto os partidos de esquerda não reconheceram a importância política destas manifestações localizadas. Privilegiando apenas o ângulo das relações de produção, não viram a unidade da consciência 
reivindicativa que se manifestava ao mesmo tempo no comício e no protesto contra a precariedade das condições de moradia.

Escrevendo nos anos 70, para retomar o fio da meada, Moisés estava preocupado com a continuidade da presença popular naquilo que foi a história política à margem dos partidos, fruto espontâneo do bom senso do povo. ${ }^{3}$ Apesar de manipuladas pelas elites, as camadas populares aparecem como capazes de definir objetivos e formas de luta condizentes com seus interesses. O tema do espontaneísmo de lutas surge como complementar e inverso ao da manipulação. O grande problema para a literatura desta época é conciliar a visão crítica do sistema representativo e li crença na força e independência do povo que deve transparecer em seu sentido político inato.

\section{Weffort já mostrava que}

o populismo é algo mais complicado que a mera manipulação e sua. complexidade política não faz mais que ressaltar a complexidade das condições históricas em que se forma. $\mathrm{O}$ populismo foi um modo determinado e concreto de manipulação das classes populares, mas foi também um modo de expressão das suas insatisfações. Esse estilo de governo e de comportamento político é essencialmente ambíguo, e por certo deve muito ã ambigüidade pessoal destes políticos

3 Outros autores também buscam este significado histórico nos movimentos sociais. Essa é uma das preocupações de Etienne Henry que estudou os movimentos de "pobladores" no Peru, e que sobre eles afirma: "A análise dos movimentos sociais não se restringe à mera recomposição cronológica das mobilizações acontecidas durante um período determinado. Também não se reduz à visão positivista que emana do discurso ideológico de seus protagonistas, elaborado por elementos conscientes que guiam a ação das massas. Baseia-se na leitura da inscrição dos movimentos sociais em um processo que lhes dá significação histórica (...)" (Henry, 1978, p.137). divididos entre o amor ao povo e o amor ao poder (Weffort, 1978, pp.62-63).

Mas o próprio Weffort demonstra com clareza seu desagrado quanto ao caráter mistificador da ideologia populista, através da qual "o operário se expressa de maneira pequeno-burguesa" (Weffort, 1978, p.36).

E este será o traço exaltado pelos autores mais recentes, que longe da época populista, esquecem a ambigüidade e enfatizam a mistificação.

É bom lembrar que as ciências sociais, nesta última década, estiveram dominadas pelas problemáticas da ideologia. $\mathrm{O}$ estudo dos aparelhos ideológicos responsáveis pela hegemonia burguesa tiveram grande influência e recolocaram em novos termos o velho problema da alienação. Ao definir o campo ideológico como a instância privilegiada para a dominação, alguns cientistas sociais colocaram de um mesmo lado todos os canais institucionais de manifestação política (partidos, sindicatos etc.) e de outro os eventos independentes. Fez-se a crítica geral dos partidos (de direita e de esquerda) para recuperar as formas de expressão dos interesses políticos em sua "naturalidade", isto é, aquilo que explode nos interstícios do sistema e resiste ã domesticação pelos aparelhos ideológicos.

Nesta linha, um dos problemas que a pesquisa deveria enfrentar é como qualificar sociologicamente essas variadas irrupções. Se elas não são vistas como expressando estritos interesses 
de classe, manifestam quase sempre uma reação ã dominação e unem os oprimidos. Por isso, passou a ter curso a noção de classes populares que, sendo mais abrangente que o conceito de proletariado, é bastante mais imprecisa.

A teoria da marginalidade já demonstrara que o setor operário era minoritário em nossas metrópoles e estava cercado por vários tipos de trabalhadores assalariados e autônomos. Todos compartilham as mesmas péssimas condições de vida urbana. Mas, enquanto os analistas da marginalidade esperavam uma explosão dos "excluídos", a classe popular que se manifesta nos anos 70 luta para que a sociedade política a reconheça. É como parte deste sistema que reclamam maior igualdade e mais participação. Isolados em seus bairros, os cidadãos enfrentam o Estado como grupos de pressão fragmentados e que competem pelos mesmos recursos. A unidade destes de mandantes (que não podem ser qualificados como uma classe) é dada pelo Estado, que é ao mesmo tempo inimigo e legitimador. E sua força é dada por uma "cultura" própria onde se preservou a rebeldia.

Poderíamos dizer que a expressão classes populares se refere, em geral, à presença de setores sociais que empobreceram com o modelo de desenvolvimento em curso e que estiveram excluídos das decisões políticas. O seu uso é quase metafórico, pois sintetiza a ideia de grandes contingentes (massas) de baixa renda que, apesar de indefesos, guardam a capacidade de distinguir suas necessidades básicas e irromper de tempos em tempos, reclamando maior igualdade. Foi privilegiando a dimensão política que se definiu este novo ator que não luta apenas por melhores salários, mas generaliza suas reivindicações buscando uma sociedade mais democrática.

O que é apresentado como traço inovador da participação popular é sua espontaneidade e seu senso de justiça que garantem, ao mesmo tempo, sua independência das elites e dos partidos e a justeza de suas demandas decididas entre iguais. Por apresentarem estas qualidades, supostamente, os movimentos populares são apresentados como instrumentos políticos novos. $\mathrm{E}$ isto porque:

1) Questionam o Estado autoritário, obrigando a uma democratização;

2) Fazem reconhecer a presença dos oprimidos;

3) Como novos atores políticos, colocam-se ao lado dos partidos e sindicatos, renovando-os, porque têm a capacidade de intervir autonomamente na correlação de forças.

Entretanto, as pesquisas que procuram descrever a ação política popular nem sempre demonstram a existência dessas características. Apesar de que quase todas terminam por reafirmar sua crença em que a expansão dos movimentos sociais criará condições para uma transformação fundamental da sociedade, os estudos de caso não autorizam tanta esperança.

Os movimentos estudados não são convincentes quanto ao papel democratizador da participação popular que colocaria em xeque o autoritarismo do Estado. Mostram, pelo contrário, que as várias faces que o Estado apresenta neste diálogo aumentam sua 
margem de manobra e são capazes de absorver efetivamente algumas das demandas populares. Dito de outra maneira: em certos níveis administrativos encontramos uma real influência das mobilizações que conseguem obter respostas dos organismos públicos, mas o efeito destes desafios sobre o aparelho estatal em seu conjunto é discutível.

Tomemos o caso da reurbanização de Brás de Pina, muito bem estudado por Carlos Nelson Ferreira dos Santos (1981, pp.31-94) e onde aparece uma detalhada descrição das mudanças de política dos órgãos públicos. Este trabalho se destaca por apresentar uma excelente etnografia de três movimentos de resistência à política habitacional e, ainda, por uma postura crítica muito positiva. Seu ponto de partida é descobrir as relações entre todos os personagens envolvidos neste processo reivindicativo e como as funções de cada um vão mudando com o desenvolver do movimento. Estuda as diversas partes envolvidas sem atribuir uma essência democrática ao que vem do povo ou autoritária ao que vem do Estado. Na teia que se vai constituindo, os personagens assumem identidades diferentes e vão mudando seu significado, o que nos permite compreender os efeitos da atuação de uns sobre os outros.

O que o caso de Brás de Pina nos ensina é que o enfrentamento político direto, e quase escandaloso, entre favelados e governo do Estado que dá início à reivindicação de reurbanização da favela, muda de qualidade com a interferência de técnicos do Estado (COPEG), cujo objetivo é encaminhar a solução das reivindicações. $\mathrm{O}$ autor deste trabalho, que também foi personagem deste processo, nos faz o seguinte relato:

Essa primeira visita (do Grupo de Trabalho do COPEG) foi cheia de surpresas para todos os lados. A associação ficara muito desconfiada. Aquilo por que declarava estar disposta a lutar com. todas as forças de repente lhe caía do céu. Os técnicos do G.T. se maravilharam: os favelados já sabiam tudo sobre a novidade que eles lhes foram anunciar e até puderam exibir, com muito efeito, etapas e estatísticas... Havia uma linguagem comum e quem comandava a conversa não eram os representantes do Estado. Logo se procurou saber quem era o instrutor e o conversor, e os favelados se referiram, com orgulho, a seus assessores urbanistas, isto é, a nós. Por isso tivemos a honra da visita intempestiva. A partir daí formou-se uma rede muito complicada. Havia um novo agente em jogo, o Estado, que, de opositor e inimigo que permitia a unidade de todos os outros atores, passava a se propor como aliado... (Santos, 1981, p.53).

Este deslocamento do papel dos órgãos governamentais não ocorre apenas neste caso. Em quase todos os processos reivindicativos podemos reconhecer um momento inicial de mobilização que identifica obstáculos e opositores que supõe um discurso radical. Entretanto, a continuação da campanha supõe contatos com esferas específicas do Poder Público que podem atuar de maneiras distintas e muitas vezes contraditórias. O conjunto dos órgãos públicos, apesar de submetido a orientações básicas comuns, desenvolvem políticas parciais com objetivos diversificados e oferecem à população usuária faces bastante diferentes. Além do mais, as políticas públicas mudam de rumo de tempos em tempos, atendendo a novos objetivos políticos ou a incentivos de fontes financiadoras internacionais.

Este é o caso da política habitacional no que diz respeito ao 
atendimento de favelados. As várias formas de remoção de favelas, a reurbanização dos terrenos já ocupados, o auxílio para construção de casas mais sólidas etc., as vilas de habitação provisória, são formas de intervenção que foram se sucedendo no tempo e para as quais foram sendo criados órgãos específicos. Estes órgãos competiam dentre si tanto por recursos como por eficácia política. Em todas estas fases, as ações estatais estão justificadas por planos e metas que incluem, necessariamente, o atendimento ao usuário. Os movimentos sociais vão disputar o direito a este atendimento e procuram influir sobre sua qualidade.

As classes populares estão atuando com um duplo jogo que pretende, ao mesmo tempo, lutar pelo reconhecimento de seus direitos como cidadãos e viabilizar suas demandas, diminuindo suas carências. Se aceitarmos este duplo caráter dos movimentos reivindicativos, podemos compreender as oscilações que ocorrem em todos eles, entre momentos de maior e menor participação e também a coincidência entre pronunciamentos altamente críticos sobre o governo' e as negociações contínuas com os funcionários encarregados dos contatos com o público. O caso de Brás de Pina, já citado, é um exemplo raro pelas circunstâncias especiais em que se desenvolveu. A agência estatal encarregada do projeto de urbanização terminou por instalar-se no local da favela, competindo com os outros atores envolvidos no processo reivindicativo (Igreja, arquitetos que trabalhavam voluntariamente e a Associação dos Moradores) e negociando diretamente com os seus clientes, afastando toda mediação.

Uma ação estatal radicalmente oposta teve lugar na cidade de São Paulo, quando os moradores da Vila São José enfrentaram a SABESP exigindo que o bairro fosse servido por água encanada (Jacobi, mimeo, s.d.). Órgão criado para executar uma política centralizada de saneamento básico para o 'Estado de São Paulo, a SABESP não tinha em 78-79, época desta reivindicação, uma política de contato com seus clientes. Portanto, as manifestações programadas pelos moradores da Vila São José, apoiadas por outros bairros vizinhos, pareceram aos funcionários desta empresa como inesperadas e impertinentes. A racionalidade do planejamento de redes de água e esgoto não incluía a consulta aos usuários e estava baseada em objetivos estabelecidos a longo prazo e sujeitas às limitações técnicas.

Em outubro de 1978, aproximadamente 800 moradores da Zona Sul, região de Shangri-lá, que representavam 32 bairros, apresentaram-se diante da sede da SABESP para exigir que o problema da falta de água encanada fosse resolvido imediatamente.

Três diretores da SABESP, convocados às pressas, atenderam os moradores e, diante de seus slogans insistentes como 'Socorro SABESP — estamos com sede'; 'A SABESP minha gente, água pros ricos faz jorrar. Mas o povo não é bobo e isto nós vamos provar', pediram um prazo de 10 dias para solucionar o problema (Jacobi, s.d., p.41).

O desenvolvimento desta campanha aproximou público e funcionários e tornou pessoal o enfrentamento. Os diretores que tiveram de às pressas, abandonar suas rotinas de trabalho foram 
substituídos por um senhor Vlademir, que se tornou o porta-voz da empresa. Este senhor foi criticado em versinhos e discursos, faltou a várias assembléias para as quais foi convocado, mas dialogou tom o movimento. A SABESP foi obrigada a sair de seu isolamento técnico e procurar soluções. No dia 17 de maio de 1979, a presença em sua sede de novecentos moradores desta região — que irritados afirmavam que "o prazo alegado pela SABESP não é técnico, é político" — produziu como reação "um comunicado que dizia:

1. Haver um projeto técnico para o setor, em fase de elaboração, e com início previsto para o último trimestre de 1979. Implementação simultânea de água e esgoto:

2. Como medida de emergência, as áreas de Shangri-lá serão abastecidas a partir de derivações da linha de Bororé, sem prejuízo deste" (Jacobi, s.d., p.46).

Não parou aí o movimento. A última manifestação descrita nesse trabalho foi uma assembléia na igreja de São José em novembro do mesmo ano, onde compareceu o Sr. Vlademir. Assistiu a uma peça de teatro em que os moradores o criticavam diretamente e prometeu o início das obras para aquele mesmo mês.

Alguns aspectos desta história são importantes. Em primeiro lugar, os funcionários saem de suas salas com ar condicionado e acabam tendo de ir às sacristias de igrejas distantes suportar críticas diretas. Em segundo lugar, a SABESP responde a demanda que não estava nos planos com pelo menos um estudo, que viabilizava uma solução ainda que precária (derivação da linha de Bororé). Quanto à população da região de Shangri-lá, organizou-se, debateu, mobilizou muitos bairros, exercitando um direito que já tinha usado anteriormente para defender-se no caso dos loteamentos clandestinos. As reações da empresa pública mostram que a população pode impor algumas mudanças de atitude, mesmo aos planejadores mais distantes dos interesses populares, mas que é impotente quanto a modificações na política geral da empresa. Podem conseguir água para os bairros que não contam com esse serviço mas não podem obter esgotos, por exemplo, senão nas zonas já incluídas nos projetos aprovados. Desde que o governo paulista optou pela lenta e dispendiosa solução SANEGRAN, a periferia sabe que a falta de saneamento básico não será resolvida a curto prazo. Apesar de não atender aos interesses populares, mudanças substantivas nestes planos não estão ao alcance dos setores populares. As decisões e as prioridades foram definidas fora da sua arena de luta.

Os favelados de Brás de Pina, neste aspecto, tiveram uma experiência mais favorável porque conviveram com um órgão estatal que, por circunstâncias locais e pela sua área de atuação (habitação para populações de baixa renda) desenvolvia uma política que reconhecia a demanda de seus clientes como fundamental para o atendimento.

Mesmo em casos não tão bem-sucedidos, é preciso considerar a necessidade que tem o Estado, por mais autoritário que seja, de 
responder a esses movimentos. ${ }^{4}$ É claro que responde de maneiras variadas segundo a época, a conveniência política e o tipo de reivindicação. Em alguns momentos pode mesmo cortar o diálogo usando a repressão direta. Mas justamente porque estamos diante de um governo tão pouco democrático é que devemos nos perguntar: por que nossos movimentos populares são semelhantes e contemporâneos àqueles que ocorrem onde há democracia representativa? Por que eles se concentram em certos momentos em determinadas demandas?

Não há dúvida de que neste país sempre houve miséria urbana e que reivindicações por água, esgoto, escola e transporte não são novidades recentes. Parece muito simplificador tomar as carências das periferias urbanas como fator capaz de produzir espontaneamente a mobilização para a ação. Como já vimos, algumas vezes se supõe que a supressão dos canais institucionais de expressão de interesses facilitou a ação direta e autêntica das bases populares. Sem tutela, o povo começou a criar mecanismos de comunicação com as agências estatais, desafiando-as.

Mas é preciso olhar também para as transformações ocorridas com a burocracia pública, pois as demandas populares se concentram em certas áreas (especialmente as que são consideradas politicamente prioritárias) e em certas regiões. Isto talvez indique que a formulação

4 Convém notar que um dos únicos trabalhos que toma de frente a reação do Estado aos movimentos sociais é o de Renato Boschi e Licia Valadares. Tendo como base uma ampla documentação empírica, estes autores discutem a função das mobilizações populares na abertura de um espaço de diálogo com o Estado. destas políticas e a criação dos mecanismos para implementá-las têm um efeito indutor de reivindicações. Convém lembrar que as metas sociais prioritárias são bastante semelhantes quando comparamos diversos países em desenvolvimento onde existem ou existiram movimentos sociais.

É óbvio que estas observações não pretendem diminuir o valor da iniciativa do povo, uma vez que não acredito que possa ser continuamente manipulado e vejo estes enfrentamentos reivindicativos como produtores de um espaço próprio de debate com os governos.

As classes populares sempre reivindicaram habitações decentes e serviços urbanos, mas o mecanismo de pressão era diferente. A existência de planos públicos com fins sociais faz com que os Estados contemporâneos, por mais antipopulares que possam ser (e freqüentemente são) implementem políticas sociais globais que criam expectativas de demanda.

No caso de Brás de Pina, isto apareceu claramente, e no caso do movimento paulista surgiu uma pequena flexibilidade dentro de uma empresa que antes era absolutamente rígida. Foi certamente a mobilização que abriu estas brechas, mas ainda não vemos claro como funciona este mecanismo. Concordo com Bosehi e Valladares quando afirmam que:

não é freqüente por parte dos setores do aparelho de Estado no Brasil, por contraste a outros países, mesmo aqueles setores responsáveis pela implementação de políticas voltadas às populações de baixa renda, o reconhecimento de movimentos reivindicativos como os interlocutores legítimos das 
populações.

Como se poderia esperar, a 1ógica envolvida no processo de obtenção do monopólio da representação - tanto no âmbito interno das populações, quanto frente ao. Estado - é bastante mais complexo do que à primeira vista pode parecer. Não apenas está ausente na lógica de atuação do Estado brasileiro, historicamente o padrão de reconhecimento de bases autônomas de representação, como também, por vezes o Estado rompe o monopólio da representação com o estímulo às organizações paralelas, como ilustra o caso das Associações de Favelados no Rio de Janeiro (Bosehi e Valladares, 1981, p.10).

Acredito, entretanto, que, apesar do funcionamento tradicionalmente autoritário do Estado brasileiro, a implementação das políticas sociais, atualmente, obriga a algum tipo de inter-relação com a população. Apesar de que os nossos planejadores contam com instrumentos muito eficientes para impor suas razões técnicas, não podem deixar de lado as condições de demanda por seus serviços. Não podem, quer porque pagariam um alto custo político, quer porque a própria ideologia da intervenção estatal na área social pressupõe o diálogo. E convém não minimizar este último fator porque é ele que abre espaço para organismos e funcionários pouco ortodoxos (como os de Brás de Pina), ao mesmo tempo que garante para os movimentos populares o apoio de agentes externos (Igreja, profissionais etc.) que legitimamente reclamam por uma distribuição mais democrática dos serviços coletivos.

E aqui chegamos a um ponto importante. Para qualificar os agrupa mentos populares como autênticos, tem-se dado tanta ênfase à sua representatividade de classeque praticamente se deixa de lado a existência de interferências externas ao grupo. Os exemplos já relatados e quase todos os outros conhecidos mostram o papel essencial da Igreja, de profissionais liberais, além de várias instituições que podem circunstancialmente auxiliar a mobilização e divulgação das manifestações.

Reconhecer a presença destes personagens considerados "estranhos" à comunidade nos obriga a responder a duas ordens de questões:

1) Por serem externos a ela, estes assessores são necessariamente manipuladores de opinião?

2) O que é esta comunidade?

À primeira questão podemos imediatamente responder pela negativa. Todos os relatos disponíveis mostram o papei fundamental destes "organizadores" ${ }^{5}$, sem cujo apóio não teríamos a divulgação e expansão de movimentos que temos atualmente. Para não alongar demasiado este tópico, basta lembrar que sem o apoio das paróquias a grande maioria das manifestações não teria sequer local para reunião, e menos ainda possibilidade de intercomunicação. A Igreja fornece uma rede de contatos, um espaço democrático de discussões e um

5 Uso a expressão "organizadores" no sentido que os participantes dos movimentos de base americanos a utilizam. Trata-se de indivíduos que ocupam uma posição chave no grupo e que têm um saber técnico importante para a mobilização de recursos financeiros e humanos. Nos EUA, muitos grupos contam com "organizadores" assalariados, ainda que esta não seja a regra geral. Veja-se a este respeito os trabalhos de Perbnan (1976) e Singer (1980). 
mínimo de proteção, que a torna um elemento imprescindível nesta nova realidade. Também a imprensa tem, sem sombra de dúvida, uma função crucial, porque a eficácia dos protestos populares depende muito da divulgação. ${ }^{6}$

Além da Igreja, grupos de profissionais oferecem assessorias técnicas valiosas. O movimento de loteamentos clandestinos, por exemplo, não existiria sem o apoio voluntário de alguns advogados. Arquitetos, professores e médicos também colaboram com grupos populares, desejosos de dar sentido político ao seu saber profissional. Este é um fato novo, que resulta, por um lado, da consciência do poder controlador do saber, e por outro, do desejo de alargar a presença popular na política. A generalizada descrença nos partidos e a valorização da prática política direta criaram entre os técnicos o desejo de oferecer seus conhecimentos para alargar o espaço de autonomia dos movimentos sociais. E os exemplos que conhecemos confiram estas boas intenções. Entre o assistencialismo e a militância, os profissionais encontraram seu campo de ação.

Constatada a importância dos "organizadores", resta a outra questão que colocamos: por que eles são classificados como "de fora" da comunidade se lutam pelos mesmos objetivos? Estes atores se distinguem das bases das associações tanto por sua origem de classe, quanto por suas qualificações intelectuais. Mas estas marcas não

6 Veja-se, a propósito, as considerações de Santos (1981, p. 35) sobre o início do movimento de Brás de Pina e também as descrições de Castells para Madri (Castells, 1980). obrigam a mantê-los como estranhos. Alguns podem mesmo optar por viver na periferia, compartilhando os mesmos problemas dos moradores. e esta, quase sempre, a situação dos padres.

Entretanto, os limites do grupo são demarcados por outros critérios. O que define a comunidade é uma experiência comum de discriminação que enfatiza o compartilhar de certas carências, percebidas como injustas.

Todos os movimentos sociais reúnem pessoas que sofrem uma mesma opressão. O movimento das, mulheres, dos negros, dos hippies ou dos homossexuais tem sua base na cooperação entre aqueles que real ou imaginariamente compartem os mesmos problemas. E é por isso que todos eles só reconhecem como membros plenos aqueles que podem exibir esta condição comum; nos grupos feministas, por exemplo, só as mulheres são aceitas. Alguns poucos homens podem ser aliados, porque demonstram uma adesão intelectual que, entretanto, nunca pode substituir a vivência da condição feminina. Nestas condições, a definição de posições políticas resulta de discussões que passam pelas emoções e pela subjetividade, espaço este visto como privilegiado para a formação de um espírito coletivo.

Esta característica dos movimentos libertários reaparece nos bairros através da vivência da pobreza. São sobretudo grupos de pessoas que se sentem excluídas dos benefícios, injustiçadas. Pouco importa se existem diferenças de nível econômico entre os participantes. O que os une é um sentimento e não a exigüidade de 
recursos. A comunidade é percebida como uma experiência de igualdade. Retoma-se a oposição clássica entre comunidade/sociedade para confrontar a unidade de interesses dos grupos de base com a sociedade que, por definição, é dividida em classes e cortada por privilégios e conflitos. Entre iguais se supõe poder garantir o consenso e a liberdade ${ }^{7}$.

Não vou, neste momento, discutir o modo de funcionamento destas auto-denominadas comunidades ${ }^{8}$. Quero apenas definir seus limites para poder compreender seu modo de atuação. Sem dúvida, esta ideologia comunitária garante autonomia para os grupos mobilizados mas muitas vezes leva também ao seu isolamento. Constituídos para lutar contra as discriminações que sofrem, freqüentemente as mulheres, negros, homossexuais ou pobres mantêm paralelas suas campanhas, que acabam perdendo a eficácia.

No caso das reivindicações populares estas limitações são visíveis. Todos os grupos se identificam ao nível ideológico (todos vivem a mesma pobreza) mas competem entre si enquanto demandantes frente ao Estado. Este fato põe a nu uma ambigüidade constitutiva destas ações políticas, nem sempre reconhecida.

7Boschi e Valladares (1981) foram pioneiros ao levantar a questão do significado da noção de comunidade. Entretanto, limitaram a discussão ao aspecto teórico da definição, sem analisar o modo como o conceito é utilizado. Procuramos indicar aqui apenas algumas dimensões desta noção, mas seria importante retomar a sugestão destes autores e estudar a utilização da expressão pelos agentes de políticas públicas.

8 Veja-se, nesta linha de argumentação, Cardoso (1982) e Caldeira (1982).
Quando os sociólogos afirmam que o Estado, por ser o inimigo comum, é o unificador dos movimentos sociais, estão expressando uma parte da realidade. Tomando por este ângulo, a vivência da condição de injustiçado permite a criação de uma identidade abstrata que só se concretiza diante do promotor da injustiça - o governo. Mas, todos os mecanismos que os órgãos públicos utilizam para responder às reivindicações populares levam à sua fragmentação e separação. Cada grupo se dirige a uma esfera da administração e pode se defrontar com políticas tão diversas que chegam a ser contraditórias. Em certos momentos encontram receptividade e em outros deparam com uma grande inflexibilidade. ${ }^{9}$ Além disto, os modos de reivindicar são diferentes para cada grupo e também mudam durante o seu desenvolvimento. Compreender que esta ambigüidade faz parte do movimento social nos arma para escapar das interpretações classificatórias que procuram encontrar ou um conteúdo transformador, quando o discurso é radical, ou uma acomodação quando o governo atende aos pedidos. Nesta oposição, sempre está presente o fantasma da manipulação e do populismo de

9 No momento, no Estado de São Paulo, quase todos os grupos que pediram postos de saúde foram atendidos. Isto se deve, em primeiro lugar, ao momento pré-eleitoral mas, provavelmente, também a uma específica flexibilidade na alocação de verbas para estes fins. Os serviços de saúde atendem ao interesse popular, mas, provavelmente, também respondem à expectativa de setores empresariais ligados ao governo municipal e que vêem com bons olhos a difusão destes equipamentos. Para o município de São Paulo, expandiu-se a rede de iluminação pública para quase todos os bairros. Uma das razões que explicam esta expansão é que já não é necessário que a rua tenha guias para ser iluminada. 
Estado que são a contrapartida da procurada autenticidade da participação popular. Parece útil admitir que o povo também manipula quando pode e, atualmente, pelo menos negocia com certo desembaraço com as agências públicas.

Como vimos, os discursos mudam de tom com o desenvolver dos acontecimentos e, por outro lado, quando as demandas são atendidas, fica sempre um saldo positivo para as organizações. Em geral, as primeiras vitórias alimentam mobilizações posteriores e reafirmam a consciência da cidadania que legitima o enfrentamento com as autoridades.

E nem sempre estas vitórias são apenas locais. Apesar da situação de competidores em que o Estado os coloca, muitos bairros já se uniram em uma mesma campanha. O movimento pró-creches foi um exemplo recente. Esta ação coletiva é possível porque as "comunidades populares" se sentem como partes de um mesmo conjunto. Se o Estado opera aglutinando e segregando as classes populares, as organizações de base, apesar de seu isolamento, também conseguem, em certos momentos, conjugar ações. Nestes momentos de união, manifesta-se nitidamente o lado expressivo das campanhas políticas, cujo objetivo é expor, usando o máximo de recursos simbólicos, a exclusão das camadas populares criando, pelo menos, a ilusão de sua unidade. Seu outro lado é reivindicativo e prático, e se define pela negociação. Nela, às vezes ganham e às vezes perdem, mas, até agora, não tiveram força para provocar uma inflexão nos objetivos das políticas governamentais. Mas nem sempre esse é seu objetivo. Algumas vezes, parece que os movimentos sociais saem à rua para perder. Conta menos a vitória que a união em si, que o sentimento de pertencer. Talvez essa seja uma das razões por que são tão numerosas as lideranças femininas nestes grupos, apesar de que elas continuam ausentes da política partidária ou sindical. Mobilizar homens para ações cujo resultado é imprevisível e incontrolável é bastante mais difícil. As mulheres podem correr o risco da derrota com mais tranqüilidade, especialmente porque sempre reivindicam enquanto mães e esposas. Mas é claro que este exercício produz seus frutos porque legitima a extensão do espaço feminino da casa para a rua. E isto não se faz sem conseqüências.

Entretanto, algumas vezes surgem movimentos que procuram influir em decisões políticas de alcance global. O "Movimento do custo de vida" é o mais caro exemplo deste tipo de campanha. Não tinha uma reivindicação específica para ser atendida por alguma precisa agência do governo; apresentava o problema das classes trabalhadoras — a relação salário custo de vida — e exigia uma ação positiva do governo em seu conjunto. ${ }^{10}$ A manifestação se fez através de listas de assinaturas, método reconhecidamente ineficaz. Os

10 Eunice R. Durham, no relatório elaborado para o UNRISD, discute o modelo de representação da sociedade e do governo que é utilizado pelas classes populares. Neste modelo, o governo é concebido como distante e externo. Como o "custo de vida" é um problema afeto a esta esfera e não do poder local, compreende-se por que o "Movimento contra a Carestia" orientou de maneira imprecisa sua reivindicação. 
setores populares procuram sempre meios diretos (passeatas, concentrações, assembléias) como forma de pressão mas, para a longa campanha do custo de vida, além de alguns atos públicos, o que garantiu sua continuidade foi a coleta nacional de assinaturas.

1) Dirigem-se contra o Estado autoritário, obrigando-o a uma democratização.

Com os dados apresentados na literatura sociológica é difícil sustentar esta hipótese. Atualmente, o Estado reconhece as associações populares como interlocutores e se torna mais flexível diante de suas demandas. Porém, as finalidades sociais e o controle de sua aplicação escapam totalmente ao âmbito de ação dos movimentos sociais.

\section{2) Obrigam a reconhecer a presença dos oprimidos.}

Certamente as manifestações populares ganharam espaço na sociedade. Elas dependem deste espaço para sua multiplicação e eficácia. Os "organizadores" têm um importante papel como formadores de opinião e legitimadores das demandas. Mas a contribuição mais importante dos movimentos populares foi ter dado demonstração da presença ativa das camadas excluídas. No Brasil, o povo sempre foi apresentado como passivo, desunido e incapaz de ação autônoma. É claro que esta descrição foi produzida por nossa tradição elitista, mas ela é tão forte que se faz notar até mesmo no pensamento de esquerda. Em alguns casos, ela se esconde atrás da busca de critérios de autenticidade que definem algumas manifestações como espúrias e outras como verdadeiras a partir da definição formal das questões prioritárias. A crença na passividade das massas começa a ser contestada na prática e, como conseqüência, o Estado precisa encontrar mecanismos para reconhecer quais são os representantes do povo com quem dialogar. Parece mais fácil para nosso governo legitimar as lideranças de bairro como seus interlocutores que os partidos políticos com suporte popular. E é mais fácil porque neste diálogo ele apresenta suas variadas faces e negocia a partir de uma posição de força. Os partidos políticos, entretanto, põem em causa o modo de funcionamento do Estado como um todo.

E chegamos à última questão:

3) Os movimentos sociais, como novos atores políticos, poderão ter uma ação renovadora sobre os partidos e sindicatos. O que manteve este movimento? Certamente sua capacidade de expressar uma identidade popular baseada no sentimento de injustiça que unia todos os participantes. Não se buscava uma resposta concreta: movimento era um fim em si mesmo ao expressar o desejo de que o governo federal controle os preços permitindo uma vida melhor.

Embora movimentos como estes, quase puramente expressivos, sejam raros, esta dimensão existe em todas as manifestações populares. Não são apenas as reivindicações que unem os participantes de um movimento e por isso mesmo sua ação negociadora nem sempre é a mais direta ou a mais eficaz. A união é uma virtude em si mesma e para mantê-la, tanto se usa a discussão muitas vezes infindável, quanto os cânticos ou outras formas lúdicas 
que hoje fazem parte de qualquer reunião.

Enfim, o lado expressivo e o lado reivindicativo estão sempre e necessariamente juntos no desenrolar desses processos. Esta específica conjugação é uma característica dos movimentos contemporâneos.

A consciência de uma condição comum na pobreza e a crença em direitos garantidos pela justiça social dificultam bastante qualquer tentativa de cooptação das classes populares pelo Estado. A solução das carências apresentadas pode, em certa medida, alimentar as organizações populares, especialmente nas condições de desamparo de nossas periferias urbanas. Ademais, gozando melhores condições de vida, estes grupos podem dedicar-se a outras atividades que também expressem sua identidade básica, tais como festas tradicionais, clubes esportivos locais, danças ou associações que sirvam de marca para ó bairro. ${ }^{11}$

11 Veja-se o relato de Santos (1981, pp.151 e segs.) sobre o bairro do Catumbi. Castells também descreveu o interesse dos habitantes de novos bairros de Madri por reconstruir e reinventar uma história local que pudesse servir de base para cerimônias e festas que unissem a todos em torno de tradições que por serem desconhecidas não eram menos importantes. Convém lembrar que este mesmo processo está ocorrendo em São Paulo, onde festas que já não interessavam a ninguém estão sendo revitalizadas com grande êxito. A festa de San Genaro na Mooca ou de N. S. Acheropita no Bexiga só eram lembradas pelos muito velhos e hoje conseguem reunir multidões vindas de longe para participar destes, rituais identificadores de certas áreas da cidade.

\section{Conclusão}

Retomando a discussão sobre as novidades que os movimentos de bairros trazem para a política, é preciso reavaliar os três pontos que apresentamos anteriormente:

O que esta afirmação supõe é que, por serem organizações de base e por isso representarem os reais interesses das classes populares, os movimentos poderão exercer uma influência positiva sobre os partidos que, por serem uma instituição hierarquizada, mantêm os centros decisórios longe das bases.

O que procurei mostrar é que a autonomia ideológica dos movimentos não garante a possibilidade de intervenção na correlação de forças dos sistemas políticos dominantes. Sua ação reivindicativa, ainda que autêntica, é positiva porém fragmentada e limitada pelo próprio aparelho do Estado.

Quanto à ação conjunta de associações populares, partidos e sindicatos, ela pode se dar sempre que a dimensão acentuada por todos seja a expressão do sentimento comum de opressão. E a manifestação simbólica desta união dos excluídos é politicamente muito importante e tem ocorrido em situações especiais, As greves de São Bernardo e outras manifestações de massa têm dado ocasião a esta ação comum. Entretanto, parece difícil prever ações políticas conjugadas, uma vez que a condição necessária para a organização de movimentos sociais é a experiência compartilhada e o consenso. Apesar da influência que esta ideologia de valorização das bases, de negação das hierarquias e dos mecanismos representativos parece ter, 
os sindicatos e os partidos são por definição hierarquizados e atuam através de representantes.Por outro lado,os moradores se unem pelo que tem em comum, mas se separam quanto a filiação partidária ou quanto a opinião sobre as lutas sindicais . Esta questão é bastante complicada e merece ser tratada com mais detalhe que, naquelas situações em que ocorreu a convivência de um movimento popular forte e partidos também populares e mobilizadores, o estreitamento do contrato não deixou saldo positivo. Castells apresenta algumas descrições do que ocorreu com Madri (Castells, 1980, cap.VI) e Meunier faz com que sua tese um impressionante relato da presença dos partidos no "Campamento Nueva la Habana" em Santiago do Chile (Meunier, 1976). Parece ser difícil encontrar complementariedades entre atividades tão diversas.

Em lugar de os movimentos fecundarem os partidos, como foi a esperança de muitos, a atuação militante frequentemente enfraqueceu os movimentos.

Esta difícil questão ainda está desafiando os participantes dos movimentos negros, feministas ou ecologistas. Sempre que, consciente dos limites de sua ação, procuram nos partidos instrumentos para transformar o Estado, estes movimentos perdem força e muitas dissidências se manifestam. É que tomar partido implica romper o consenso criado pela vivência comum. Por outro lado, os partidos têm dificuldade para incorporar as reivindicações parceladas e às vezes contraditórias que lhes são apresentadas. Talvez o caminho mais fácil seja procurar somar apenas no momento de lutar por um sistema de governo mais democrático, onde o espaço aberto para as reivindicações seja maior e os instrumentos de decisão estejam sob maior controle da sociedade civil. Este campo é área de luta comum para todos.

O papel transformador dos movimentos libertários dos anos 60 se fez sentir no âmbito da sociedade, no espaço da vida cotidiana. A luta contra o racismo, o machismo e as várias formas de intolerância conseguiu mudar o modo de vida e trouxe como conseqüência a intervenção para garantir estas vitórias.

Os movimentos de bairro, quando vistos por sua face reivindicativa, não parecem capazes de grandes transformações, mas quando os vemos como expressão de uma nova identidade, é possível pensar que venham a ser uma nova peça no jogo político. Para compreender essa dinâmica é imprescindível aprofundar a análise das relações entre o aparelho de Estado e a sociedade civil.

\section{Bibliografia}

BORCHI, R. R. \& Valladares, L. P., "Problemas teóricos na análise de movimentos sociais: comunidade, ação coletiva e o papel do Estado", apresentado no V Encontro Anual da Associação Nacional de Pós-Graduação e Pesquisa em Ciências Sociais. Rio de Janeiro, 1981, mimeo.

BORIA, Jordi, Movimintos Sociales Urbanos" Buenos Aires, Ediciones SIAP, 1971.

CALDEIRA, T. P. R., Imagens do poder e da sociedade, Dissertação de Mestrado, F. F. L. C. H. - USP, São Paulo, 1982. 
CARDOSO, Ruth, "Duas faces de uma experiência", in Novos Estudo" CEBRAP,

LOJKINE, J., Le marxismes l'état et la question urbaine, Paris, Presses Universitaires de France, 1977.

MEUNIER, Christine, Revendicationl urbainel, Stratégie politique et transformotions idéologiques: le Campamento Nueva la Babana, Tese de doutorado, Paris, 1976.

MOISÉS, J. A., Classes populares e protesto urbano, São Paulo, Tese apresentada à Universidade de São Paulo, 1974.

\section{Processos sociais no Brasil pós-64: as ciências sociais ${ }^{1}$}

Otávio Guilherme Velho

Toda geração de acadêmicos possui um padrão involuntário para a sagacidade

permissível; o que vai além disso é seguidamente posto em dúvida e utilizado como base para

um ataque contra a reputação do acadêmico. F. Nietzsche

O presente texto em seu aspecto informativo apóia-se nos trabalhos pertinentes que vêm sendo publicados e em certa "participação observante" pessoal. Todavia, não pretende ser basicamente informativo. Pretende, isso sim, avançar elementos de uma interpretação necessariamente polêmica, que possa inclusive servir como subsídio a um esforço de auto-análise por parte da

1Este texto, sendo em boa parte resultado provisório de um processo de reflexão que é produto de uma convivência acadêmica e profissional, deve muito a grande número de interlocutores. Gostaria de destacar os colegas do Programa de Pós-Graduação em Antropologia Social do Museu Nacional (UFRJ), bem como os colegas do IUPERJ, que me honraram com convite para em dezembro de 1981 participar em Nova Friburgo de seu seminário interno de avaliação. Referência especial deve ser feita, ainda, a Bernardo Sorj e aos demais participantes do simpósio, particularmente Vilmar Faria e Fábio Wanderley Reis, e a Gilberto Velho, que na qualidade de coordenador da Área de Ciências Humanas para o CNPq, colocou à minha disposição informação valiosa. :f: na confiança depositada no trabalho desses e de outros colegas que pode apoiar-se o interesse pela realização de uma análise do gênero da que é aqui apresentada. 
comunidade de cientistas sociais brasileiros. Por outro lado, a própria interpretação não pretende ser absolutamente genérica. Utiliza-se de uma comparação que toma como referências:

1) A atividade desenvolvida em torno da cadeira de Sociologia I da antiga Faculdade de Filosofia, Ciências e Letras da Universidade de São Paulo;

2) O sistema de pesquisa e pós-graduação em ciências sociais desenvolvido a partir da década de 60.

Essa escolhia justifica-se pela posição central desses dois elementos nas ciências sociais brasileiras respectivamente pré e pós64 e sua posição, por assim dizer, "hegemônica". Como, no entanto, essas hegemonias não homogeneízam absolutamente o espaço, não se pretende dar conta das características do conjunto das atividades dos cientistas sociais. No que diz respeito a esse conjunto, talvez estivéssemos mais próximos, apenas, de alguns elementos tendências de sua dinâmica, particularmente no que se refere à produção institucionalmente realizada no interior da academia.

Por outro lado, a própria periodização utilizada não deve ser tomada acriticamente. Como toda periodização possui algo de arbitrário, é óbvio que não se deve absolutizar 1964 em termos do desenvolvimento das ciências sociais no Brasil. Todavia, no caso isto é particularmente verdade, dado que se trata de um recorte oriundo de uma factualização política por excelência, cuja relação com a produção do conhecimento nessa área precisaria ser determinada.

Certamente - como se costuma dar ênfase no sentido negativo a relação existe: professores e pesquisadores afastados, instituições marginalizadas etc. Mesmo aí é possível, porém, que um recorte alternativo - 1968, por exemplo - pudesse disputar a primazia.

Num sentido menos linear, no entanto, seria o caso de se perguntar se 1964 inaugura um processo que se manifesta enquanto tal no domínio das ciências sociais ou, pelo menos, se simboliza de forma marcante a emergência de um processo.

Uma vez aceita preliminarmente a existência de um processo grosso modo de mudança nas ciências sociais brasileiras, a ênfase na descontinuidade ou na continuidade são ambas, enquanto construções, em princípio legítimas. Com uma nuance, porém: a percepção de que, para além das opções meramente metodológicas e arbitrárias, um recorte representa necessariamente o reconhecimento da intervenção de uma força que age com determinada eficácia, sempre relativa na medida em que isto se dá em um campo de forças.

Nesses termos, a suposição central deste trabalho será a de que aquilo que representa 1964 - embora não necessariamente em termos cronologicamente coincidentes — tem a ver com urna intervenção que tende à instauração daquilo que poderia ser caracterizado como urna nova forma de dominação no campo da produção em ciências sociais.

Isso já tem sido mencionado por outros autores em termos de modernização, profissionalização institucionalização etc. Ao colocar a questão em termos de dominação, não está em jogo um projeto 
libertário utópico alternativo que sirva de referência. Reivindica-se, apoiado numa vontade de objetividade, a colocação em moldes que permitam dar ênfase à compreensão dos mecanismos de poder envolvidos, à "cultura" específica que se vai gerando e à(s) relações disso com a produção substantiva. Em suma, reivindica-se a ênfase na "positividade" da dominação. Em matéria de utopia, se se quiser, estará apenas em jogo em termos manheimianos a passagem de urna utopia a ideologia e suas consequiências.

\section{II}

Qual utopia? Em maio de 1955 Florestan Fernandes entregou a Anísio Teixeira "para solicitar as providências cabíveis ou possíveis da CAPES (Campanha de Aperfeiçoamento do Pessoal do Ensino Superior)" um documento intitulado "Sugestões para o desenvolvimento das ciências humanas" (Fernandes, 1977, pp.94-99). Daí podem ser extraídas as seguintes proposições de alcance diverso:

1) Necessidade de ampliar as possibilidades de treinamento intensivo no campo da pesquisa;

2) Criação de um número (reduzido) de bolsas para alunos de excepcionais qualidades científicas, a serem atribuídas nos períodos do curso de especialização e no de preparação de teses para doutoramento;

3) Aumento na eficiência e plasticidade na organização do currículo;

4) Abolição do princípio da cátedra e adoção do princípio de organização departamental;

5) Aumento no número de especialistas em diferentes posições,

6) Organização de equipes de pesquisadores que permitisse estabelecer projetos de pesquisa de alcance científico definido, a formação do verdadeiro espírito de pesquisa, a constituição de mecanismos adequados ao conhecimento da sociedade brasileira e o atendimento a solicitações ou necessidades da comunidade;

7) Assegurar aos estudantes um treinamento adequado no campo do ensino e da pesquisa que lhes permitisse mais tarde operar nos centros universitários menos desenvolvidos;

8) Aparelhar a universidade para assumir através da pesquisa e da ciência aplicada responsabilidades práticas como fator de progresso no meio social brasileiro.

Segundo o autor do documento, essas mudanças se impunham na medida mesma em que o período da "aventura" dava lugar a uma nova fase, de "realização".

Em nota acrescentada quando da reprodução do texto numa coletânea em 1977, o autor esclarece que "não obstante a boa vontade demonstrada, daí nada resultou de positivo".

Todavia, é interessante observar que as proposições apresentadas na verdade fariam parte de um projeto mais amplo de universidade ao qual está associado o nome do próprio Anísio Teixeira e que encontraria a sua materialização demonstrativa em 1961 com a criação da Universidade de Brasília. E que: 
Apesar de seus problemas, a Universidade de Brasília constituiu-se em fonte de inspiração para outra tentativa de reforma universitária, ensaiada primeiro em Minas Gerais, a partir de 1964, ...e depois generalizada para o país como lei em 1968 (Schwartzman, 1979, p. 291).

Os pontos concretos da utopia expressos em forma de programa são incorporados. Todavia, as proposições de Florestan Fernandes estavam apoiadas em sua época em uma visão mais ampla das transformações democrático-burguesas da sociedade e da missão do intelectual e da universidade num processo concomitante de autonomização cultural Conforme ele deixa claro a posteriori em "A geração perdida", tratava-se de estabelecer uma identidade mantendo relações complexas com dois grupos de referência, para ele, Fernandes, representados por Oswald de Andrade e Roger Bastide: assumir a brasilidade da Semana da Arte Moderna dentro da universidade, aproveitando-se do saber dos mestres estrangeiros para exorcizar o beletrismo e o estilo de intelectual de café, mas lutando para não se deixar colonizar culturalmente (Fernandes, 1977, pp.213258). A marcação, para "dentro", do caráter científico da sua atividade (para isso distinguindo-se de uma "pré-ciência") e, para "fora", do caráter nacional da sua inserção formavam o binômio informador da utopia que teria tido o seu início de realização, vislumbre de um futuro hipotético, com a criação em São Paulo da Escola de Sociologia e Política (1933), mas, sobretudo, na velha faculdade da Maria Antônia.

Assim, é consistente com essa visão a suposição do aborto de seu projeto em 1964; o que será coincidente com a própria visão dos cientistas sociais pós-64 de que inauguravam uma prática diferente.

\section{III}

Todo recorte é, de certa maneira, um ato de força. Dizer isso não significa relegá-los para a estratosfera das distorções ideológicas. Significa assumir que são justamente essas "distorções" que constituem a matéria-prima da realidade social.

Em princípio Florestan realiza dois cortes: no tempo, entre o científico e o pré-científico, no espaço, entre o nacional (irradiado a partir da Maria Antonia) e o não nacional. Posteriormente, realizaria um terceiro: 1964.

Interessante observar que, pelo menos no que diz respeito ao primeiro desses cortes, sofreu uma crítica severa exatamente de um representante da "geração pós-64":

A simplicidade da perspectiva permite que a crítica se exima
de ser complexa. Com efeito, a historiografia que ordena o
passado em função do presente, e assumindo o presente como
o 'moderno' está desarmada para entender as exatas
articulações do desenvolvimento intelectual da humanidade. A
rigor, está desarmada até para entender o presente. (Santos,
1967, p.186).

A crítica do corte também é, inevitavelmente, um ato de força; ou, se quiserem, de afirmação. Uma parte substancial das preocupações dos cientistas sociais brasileiros na segunda metade da década de 60 constituiu-se exatamente em resgatar a "memória nacional" sepultada pela geração anterior como passo necessário à sua emancipação e à construção da sua própria identidade. Porém, ao 
realizá-lo, paradoxalmente acabaram por puxar para mais perto de si o recorte da ciência, por referência, também, à geração anterior, a qual buscaram enfrentar de início com a recuperação dos "avós" intelectuais.

Todavia, ao fazê-lo, fizeram-no em nome de algo que já estava presente em Florestan, embora em forma de utopia - a realização bastante aproximada das propostas sintetizadas no documento acima mencionado.

É assim que Florestan registra a sua visão da visão da geração de Oswald a seu respeito e a sua própria visão de si:

Os que vinham de antes, como aconteceu com Oswald de Andrade dando vazão às deformidades da Semana de Arte Moderna, viram-nos de forma errada e superficial, ou, melhor, de forma profundamente errada e superficial. Exagerando o nosso 'lado sério' de scholars ..., gozou-nos com o epíteto de 'chato-boys'. No entanto, se houve uma característica marcante e predominante nesse fragmento de geração, ela não foi a obsessão estritamente intelectualista e da erudição pela erudição, de qualquer maneira que se queira entendê-las, porém a obsessão política. Vendo-a dos dias que correm, entendo-a melhor: era uma obsessão política que nascia da cultura e gravitava dentro dela, irradiando-se para os problemas da época e os dilemas da sociedade brasileira ... (1976, p.217).

A "geração pós-64" ou o seu "fragmento" (para utilizar a expressão de Florestan) identificado com a nova modernidade, como se situa por sua vez em relação às anteriores?

Como já foi indicado, há uma certa recuperação daqueles que haviam sido considerados "pré-científicos", que inclui até por vezes uma coincidência — por detrás da aparência respeitosa — na visão que se tem dos "chato-boys". Todavia, após o momento inicial de redescoberta, servindo para, ao alargar o espectro de seus antecessores reconhecidos ao incluir em plano menos dessemelhante ao dos demais o "fragmento de geração" de Florestan, abrir a possibilidade de estabelecer novos cortes.

Num sentido geral, os princípios de distinção serão curiosamente os mesmos empregados por Florestan: cientificidade e institucionalização. Todavia, distinguindo-se os indicadores. Grosso modo, no que diz respeito à cientificidade, privilegiando-se a pesquisa empírica sistemática; e no que diz respeito à institucionalização, acentuando-se a rede institucional, o número de pesquisadores envolvidos e de pessoal formado, ou seja, a chamada massa crítica que supostamente - e ao contrário do que anteriormente ocorrera - garantiria a continuidade do processo.

Não é preciso dizer que não por acaso esses indicadores são inegavelmente descritivos com razoável precisão da nova realidade "empírica".

\section{IV}

Essa nova realidade, como não poderia deixar de ser, é definida em boa parte tendo como referência a situação anterior e, nessa, a universidade de São Paulo:

Quase toda a estrutura de pós-graduação hoje existente no Brasil foi constituída a partir de 1965. Basta lembrar que, nas áreas de Sociologia, Ciência Política e História, somente a Universidade de 
São Paulo mantinha, até aquela data, programas regulares de mestrado e doutorado. Mesmo assim, um levantamento recente no qual se acham incluídos todos os trabalhos de Mestrado, Doutorado e Livre Docência nas áreas de Antropologia, Sociologia e Ciência Política revela que somente 41 teses foram defendidas entre 1945 e 1965 (inclusive), ou seja, uma média de duas por ano. Nessa mesma instituição, de 1966 a 1977, foram defendidas 158 teses, ou seja, uma média superior a 13 por ano.

Consideradas aquelas três áreas — Antropologia, Sociologia e Ciência Política - e todos os níveis de pós-graduação, é bastante provável que a produção brasileira anual seja agora equivalente a pelo menos a metade da realizada na USP durante os 32 anos cobertos pelo levantamento citado. Isto se deve, naturalmente, ao surgimento de novos programas de pós-graduação em diferentes estados" (Lamounier, 1981, p. 4).

O autor constrói, ainda, uma tabela em que: "Dados fornecidos pelo Ministério da Educação e Cultura para o segundo semestre de 1979 e primeiro de 1980 permitem uma avaliação bastante razoável do atual panorama quantitativo da pós-graduação em Ciências Sociais no Brasil". Ver Tabela 1.
Tabela 1

TESES DEFENDIDAS E ALUNOS MATRICULADOS, POR CURSO, NO SEGUNDO SEMESTRE DE 1979 E PRIMEIRO DE 1980 (NÚMEROS ABSOLUTOS)

\begin{tabular}{|l|r|r|r|r|c|}
\hline \multirow{2}{*}{ Cursos } & \multirow{2}{*}{ No } & \multicolumn{2}{|c|}{ Teses defendidas } & \multicolumn{2}{c|}{ Alunos matriculados } \\
\cline { 3 - 6 } & & Mestrado & Doutorado & Mestrado & Doutorado \\
\hline Ciências Sociais & 16 & 82 & 22 & 920 & 130 \\
\hline História & 12 & 74 & 10 & 1087 & 74 \\
\hline Ciência Política & 5 & 14 & - & 233 & 46 \\
\hline Economia & 15 & 59 & 4 & 1078 & 107 \\
\hline Total & 48 & 229 & 36 & 3318 & 357 \\
\hline
\end{tabular}

FONTE: Lamounier, 1981, p. 5.

O mesmo autor aborda ainda na análise da interação entre as transformações institucionais (no sentido da profissionalização e da institucionalização) e a produção acadêmica de Ciências Sociais, a "transformação do marco institucional, ou seja, a constituição daquilo que Uricoechea chama de 'una rede numerosa de centros de investigación' e a "abertura do leque temático" (Lamounier, 1981, pp.2-3). A transformação do marco institucional serve também, significativamente, para qualificar o período anterior, pois se trataria agora da passagem de um "modelo burocrático-mandarinístico para um pluralista e flexível" (grifo meu), que refletiria "o coming of age de uma nova geração de profissionais" (Lamounier, 1981, p.9).

Além dos fatos mencionados acima, é significativo e 
importante o crescimento e/ou criação de associações científicas e profissionais, bem como a participação de cientistas sociais em organizações mais amplas.

A Associação Brasileira de Antropologia é um caso significativo de crescimento de uma associação preexistente. Fundada em 1953, possuía, em 1968, 141 sócios e, em 1979, 408.

A fundação da Associação Nacional de Pesquisa e Programas de Pós-Graduação em Ciências Sociais, em 1977, constitui um marco para os novos centros em torno dos quais gira a elite de cientistas sociais: justamente os centros de pesquisa e os programas de pósgraduação. Após um momento inicial de institution-building dos centros mais representativos, esses aumentam o seu grau de interação.

Finalmente, deve ser lembrada a participação crescente dos cientistas sociais na Sociedade Brasileira para o Progresso da Ciência (SBPC), que coincide com a transformação a partir de 1974 das suas reuniões anuais em eventos sem paralelo no mundo em matéria de encontro da comunidade científica com um público maior.

Essas associações passaram a exercer em proporção variável, mas crescente, funções parassindicais, corporativas e de procura de intersecções de interesses e de consenso com outros setores da chamada sociedade civil.

É de se salientar, como elemento que em parte já reflete a força e o reconhecimento da comunidade de cientistas sociais, ao mesmo tempo que tende a reforçá-la consideravelmente, o apoio "substancial" concedido a partir de 1967 as ciências sociais pelo governo, desde 1972 através especialmente do Fundo Nacional para o Desenvolvimento Científico e Tecnológico (Abranches, 1981). A partir daí as próprias reivindicações alcançam um novo patamar, embora elas próprias e as crises periódicas ponham em questão até que ponto o caráter de irreversibilidade do formato institucional alcançado seja de fato real; independentemente do reconhecimento das ciências sociais enquanto tais.

\section{V}

O fato de que a nova "construção de identidade" estava ligada à necessidade de criação de novos espaços, por contraste, é indicado em vários níveis por uma lógica de oposições:

1. No privilegiamento de outras disciplinas, sobretudo a Ciência Política e a Antropologia Social, em detrimento da Sociologia; e concomitantemente, no interior de cada disciplina, numa variação temática que, embora possua outros determinantes, pode ser analisada por esse prisma (na Antropologia, por exemplo, com um crescimento significativo da produção sobre a sociedade (neo)brasileira e na Ciência Política com um relativo abandono das questões institucionais clássicas em favor das mais ligadas à "dinâmica" política). Mas mesmo aí, não por acaso, a variação temática significando em geral um avanço sobre temáticas mais próximas da Sociologia.

2. Na própria ampliação do espaço físico, aumentando em 
importância as atividades desenvolvidas no Rio de Janeiro e em Belo Horizonte como centros "hegemônicos" competidores de São Paulo, à sombra da qual havia se desenvolvido parte dos elementos de contestação. $\mathrm{O}$ mesmo se pode dizer em relação às instituições, as novas em geral potencializando os "privilégios do atraso" e as mais antigas, acompanhadas pelas mais periféricas, aos poucos se adaptando à nova situação.

3. E, evidentemente, na própria ênfase na pós-graduação em detrimento do ensino graduado.

A ênfase na Ciência Política e na Antropologia por sua vez se articulará com uma acentuação relativa de especialização, na medida em parte, também, de uma lógica de oposição à concepção globalizante da Sociologia "pré-64", fiel nesse particular aos ideais dos fundadores da disciplina.

Assim, ao mesmo tempo que se deve relativizar os cortes, efetivamente está-se diante de elementos de uma nova forma de organização do saber em ciências sociais. O que nos interessa neste ponto é buscar analisar - embora sem pretensões exaustivas - o caráter das relações aí produzidas e da produção intelectual propriamente dita; as "ideologias" segregadas, uma vez situadas, fazendo parte dessa análise.

O ponto focal - "totêmico" — da nova organização parece ter-se centrado em torno da ideia de pesquisa. É isso que distinguiria a atividade científica dos palpites do senso comum, do beletrismo dos literatos e do ensaísmo dos intelectuais diletantes e/ou puramente teoréticos. Se isso demonstra que a construção da nova identidade se dava em oposição também a outros grupos, extra-universitários, demonstra igualmente que apesar das profissões de fé do grupo Florestan a favor da pesquisa, avaliados pela "geração pós-64" a partir de sua prática são, para esse efeito, jogados no campo oposto. Julga-se que os seus esforços de pesquisa foram basicamente malsucedidos, precedidos por longas e herméticas considerações teóricometodológicas com que se distanciaram do empirismo e do marxismo partidário (outro referencial), mas que na verdade já antecipariam os seus resultados.

A ênfase na pesquisa beneficiou-se do clima de crise e da sensação de fracasso vivida em 64 e logo após, de que uma das vertentes era o sentimento de que, apesar de todos os protestos em favor da desalienação e da inserção na "realidade", a verdade é que se tinha em boa parte vivido em um mundo político imaginário e pressuposto.

O chamado ao "trabalho", à "produção", à "seriedade" foi encontrando eco e criando uma auto-imagem que se somaria à fome de autoconhecimento por parte da sociedade de uma forma que daria às ciências sociais uma visibilidade incomum; em contrapartida, alimentando demandas e expectativas que se refletiriam sobre a própria produção.

Acrescente-se a isso a ida ao exterior para treinamento do contingente ponderável quantitativa e qualitativamente de pesquisadores e o apoio substancial de agências de financiamento, 
sobretudo norte-americanas; o que emprestará à modernização um caráter adicional de americanização, por suposto aqui também como elemento de uma oposição em termos de referência.

Assim se forjaram, concomitantemente ao aumento no número de brazilianistas, novos, mais diretos e intensivos laços com a comunidade acadêmica internacional. Aí avulta não só a referência a um padrão internacional de trabalho, mas também a assunção de posições determinadas numa divisão do trabalho intelectual que reforça a ênfase na pesquisa empírica e a abdicação de um esforço teórico sistemático que, tanto quanto referidas a uma relação assimétrica no plano internacional, significam também a atribuição, ao cientista social brasileiro, de posição similar à que já era ocupada, nos Estados Unidos, pelos especialistas nas chamadas area studies.

O retorno ao país foi acontecendo gradualmente e com ele o reforço das posições em favor da pesquisa e da modernização. Foram se criando núcleos de atividade acadêmica e de pesquisa que contrastavam não só com o grosso da atividade dentro das universidades, mas também com a intelectualidade "tradicional" extra-acadêmica, ligada a determinados periódicos de natureza "cultural" e/ou política, ao jornalismo, aos grupos de estudo informais etc.: estava em jogo também, no processo de profissionalização, a superação de uma intelligentzia (Velho, 1982).

É também indubitável que o clima de repressão reforçou a opção pela atividade mais reservada da academia, juntando-se à crença da primeira hora uma necessidade de abrigo. Nesse sentido, talvez se pudesse dizer que o apoio à pesquisa e à pós-graduação por parte do Estado que se avoluma a partir da segunda metade da década de 60 - a que também não é estranho o reforço de centros localizados fora de São Paulo - representa a "positividade" de uma dominação atualizada através de seus setores mais "esclarecidos"; embora, evidentemente, o jogo não se faça numa direção só e, portanto, não se esgote nisso o seu significado.

Uma das grandes novidades da nova situação, juntamente com a ênfase na pesquisa empírica e na formação de uma rede institucional, está no fato de garantir-se recursos não só para núcleos de pesquisadores, mas também para massa ponderável de alunos. No começo dos anos 80 o número de estudantes pós-graduados, em Antropologia Social, Ciência Política e Sociologia no país já penetrara na casa do milhar.

Aparentemente isto é apenas um dado de escala e aqui, também, o contraste é flagrante com o projeto anterior, onde a ênfase em uma "lógica dos pequenos grupos" e no gradualismo era explícita (Fernandes, 1978, esp. pp. 24 e 29). Na verdade, a produção substantiva foi influenciada por essa nova situação. Produzia-se, por assim dizer, com um olho no papel e outro no aluno; ao invés de, como antes, magisterialmente deixar por conta deste acompanhar o passo nobre e sobranceiro de seus mestres, assim se autoselecionando. E a própria produção dos alunos tornou-se ponderável e, em determinado momento, predominante.

E paradoxal. Ao mesmo tempo que se criava uma nova elite, 
"deselitizava-se" relativamente, não só a formação, mas também a produção.Um sintoma ao nível do estilo: em geral, escrever "complicado" deixou de marcar ponto, o que também pode ter-se ligado às novas relações com o mercado editorial (comparada com outras áreas da ciência a proporção de trabalhos acadêmicos que ganhavam a forma de livro tomou-se significativa) e com outros setores da sociedade. De certa maneira, as necessidades de uma relativa massificação fizeram com que se buscasse um estilo ampliável de produção e de consumo.

A maneira pela qual Fernando Henrique Cardoso avalia em 1977 seu Capitalismo e Escravidão no Brasil Meridional é expressiva:

"Quinze anos depois da publicação deste livro, sai nova edição sem qualquer mudança no texto. Uma releitura cuidadosa permitiria fazer modificações em algumas das interpretações propostas e, especialmente, aconselharia aliviar o livro das muitas notas de pé de página e de algumas complicações desnecessárias" (Cardoso, 1977, p. 11).

A ênfase na pesquisa casava-se muito bem com esse propósito. Evitavam-se os intrincados meandros teórico-metodológicos da sociologia anterior e ia-se àquilo que num certo sentido estava aberto a "todos", no limite como que magicamente. Os conceitos, a partir de agora, deveriam ter um sentido sobretudo operacional. Reconhecia-se fortemente a existência de objetos exteriores inalcançáveis por puros jogos do espírito, a ponto de a própria reinterpretação de eventos anteriores por parte de seus protagonistas tender a tingir as cores nessa nova direção, revalorizando-se atividades e personagens antes considerados secundários e, por vezes, negando-se mitos e influências antes consagrados. De certa maneira, o treinamento era enfatizado, em detrimento de um sentido mais clássico de educação.

\section{VI}

Assim, a liberação de modelos anteriores não significou fugirse à criação "positiva" de modelos de trabalho. Pelo contrário, tendência houve à substituição (em certos casos, parcial) de um modelo por outro. E de certa maneira mais impositivamente, já que nesse círculo mais amplo, menos protegido por um clima de pares aristocráticos e mais imbuído do espírito de missão quanto ao treinamento.

Em geral, cortavam-se ambições solitárias desmedidas. E não é por acaso que a categoria antes mágica de "totalidade" cai em desuso; talvez não por serem superadas as concepções básicas que a têm por referência, mas por ser ocultada ao ter a tarefa de sua "reconstrução" transferida para um ente coletivo. O "empiricismo" como categoria acusatória utilizada ritualmente no período anterior é substituída pelas de ensaísmo, filosofia, obscuridade, digressionismo, ambição e outras assemelhadas que, classificando preliminarmente, contaminam as avaliações de conteúdo.

Tudo isso, evidentemente, apesar de um investimento teórico, lato sensu, ponderável, que no entanto, esse sim, é basicamente 
centralizado e despersonalizado; além de dizer respeito sobretudo a um estilo "epistêmico", devendo ser absorvido pelos iniciantes e aparecer embutido e naturalizado nas suas análises. As informações mais "clássicas", panoramicamente fornecidas em caráter de introdução ritual no campo estrito de cada disciplina, em geral não são trabalhadas no âmbito do foco terminal privilegiado da atividade - pelo menos enquanto ideologia - que é a pesquisa, a qual absorve energias: no limite passa a ser indicador de seriedade manterse fiel e especializar-se em uns poucos objetos; criando-se subcampos específicos e uma concepção de parcelização e de "trabalhador intelectual" na direção de, em grau maior ou menor, estreitar-se o espaço para as problemáticas mais gerais e permanentes das ciências sociais e envolver-se com um volume crescente, quando não esmagador, de informações específicas.

O critério de rigor na teoria é que essa não tenha vida própria, supostamente para evitar a esterilidade das elocubrações desenraizadas.

O método no seu sentido mais estrito de modus faciendi para isso ganha primazia, a ponto de no limite (tal como se criticava na sociologia norte-americana, dos anos 50 subordinar os próprios objetos de pesquisa e determinar sub-repticiamente a sua relevância. O método ganha primazia também no seu sentido absolutamente mais geral de código, que revela aos iniciados o que é por pressuposto adequado ou não. Supor-se-á, por exemplo, certa relação necessária entre o empírico e o teórico (com algumas variantes que marcam a "subidentidade" dos diversos grupos), a cujo teste não poderia passar por sua diversidade, a maioria dos trabalhos clássicos nas ciências sociais; mas que possui a virtude de homogeneizar e de ser reproduzível, bem como pela sua observância de servir como prova de fidelidade e de não contestação. Além, evidentemente, de suas funções práticas na seleção da disputa por recursos. Em termos tradicionais, as "formalidades" tornam-se mais importantes que os "conteúdos", posto que ganham um sentido ritual e "político".

Tudo isso se justifica sobretudo por razões pedagógicas e de socialização profissional. Mas amarra também os educadores, que têm de dar o exemplo para que o sistema - do qual passam a ser funcionários se reproduza. Como a ideologia explícita é nos seus limites extremamente igualitarista, não cabe admitir uma hierarquia de competência que, vá além desse controle das regras gerais e da capacidade de atualizá-las — mais do que isso, pelo contrário, é identificado com o período anterior "oligárquico" em relação ao qual é preciso distinguir-se. A hipótese de que o que é bom para uns pode não sê-lo para todos é, nesse contexto, um indizível e um impensável.

Um bom exemplo dessa homogeneização ditada pela massificação está na construção, entre os antropólogos no processo de treinamento, de um padrão geral do bom proceder no trabalho de campo que exclui necessariamente de consideração plena a irredutibilidade do específico. O problema maior, todavia, está em que nesse e em outros casos (como na questão geral da relação entre o empírico e o teórico), mostra-se quase impossível na prática manter 
clara a ideia de que se trata de um recurso de treinamento devido a constrangimentos objetivos; e não de uma verdade geral e impositiva, valorizável em si mesma, que substitua com proveito a disponibilidade para um permanente recomeçar, avaliando e tratando cada situação informada, mas não se utilizando da informação para defender-se do jogo da avaliação e das opções pessoais e discretas, que se esgotam com cada situação e não precisam comprometer o movimento seguinte.

Nada disso, evidentemente, acaba com a hierarquia; apenas faz com que ela se exerça de outras maneiras e por intermédio de critérios aparentemente mais impessoais e institucionais. Por analogia, é como se passasse do "culto à personalidade" ao domínio do "aparelho"; o que reduz a capacidade de controle: a cristalização do modelo seguidamente afasta-se de intenções iniciais.

A ênfase na pesquisa se combina, igualmente, com a sede de informação da sociedade em geral e, também, do Estado; embora nesse último caso talvez mais como reflexo desse interesse geral. O cientista social, nesse sentido, é também visto como uma espécie de informante, seguidamente a isso reduzida a visão que dele se tem. $\mathrm{Na}$ medida em que não se exige mais e que também seja por aí que seja valorizado, isto age no sentido de marcar uma identidade onde pouco cabe o trabalho propriamente teórico para além de um certo senso comum da sociedade em geral e/ou de determinados grupos sociais que de uma forma ou de outra, material ou simbólica, sustentem a sua atividade. Nesses momentos, aparece:
1) a fragilidade da atividade propriamente científica diante da sociedade, que pouco espaço lhe dá para a construção de critérios próprios de legitimidade;

2) a coincidência paradoxal, todavia, entre certas pressões mais gerais da sociedade e as eventuais exigências da construção de uma identidade, por razões estritamente históricas.

Combinados (1) e (2), certamente desaparece a figura do "chatoboy", para quem (1) se articulava em geral com pressões percebidas como menos legítimas e/ou menos carregadas de poder de reavaliação (em parte devido à própria escala de atividades) e por isso mesmo resistíveis pela própria exacerbação ritual de um estilo e de uma prática. Mas revela-se um lado de "pés de barro" da construção das ciências sociais "pós-64", na medida em que o processo mesmo de seu avanço corre o risco de ser também o da sua imolação no altar das "razões práticas" de várias ordens.

$\mathrm{Na}$ verdade, do ponto de vista das "etapas" normalmente associadas ao desenvolvimento de uma ciência (em sua manifestação na forma de "resultados" no limite expressas por exemplo na oposição entre livros para o "grande" público e artigos para especialistas) houve, na realidade um "recuo". Embora um "recuo" que se constituiu em uma pedagogia e em uma manobra estratégica para firmar as bases sociais de apoio à ciência, de resultados, no entanto, não garantidos.

Acrescente-se a isso o fato de que haverá sempre um arquivo a desvendar ou um grupo social a conhecer. Por qualquer critério 
objetivo, é evidente que se está longe de "esgotar" aquilo cujo conhecimento empírico é válido. O problema está mais no fato de que tais critérios, quaisquer que eles sejam, vão sendo substituídos pelo informacionismo apoiado em prioridades ideológicas e/ou tecnocráticas de várias ordens. Como essas, por isso mesmo, não podem ser abertamente assumidas in totum, um balanço e uma estratégia não podem ser construídos. A isso se somam ou mesmo se combinam, no âmbito da academia, tendências, veladas por cortinas de fumaça precárias, ã rotina e ao burocratismo.

O fantasma de uma avaliação proporcional da qualidade em relação ao volume e à escala das atividades, tão salientados, ronda os acadêmicos.

Como foi dito recentemente por um avaliador especificamente para a sociologia, ultrapassando a defesa usual da imagem em que se baseiam as reivindicações dos profissionais da área:

"No Brasil, a produção científica na área da Sociologia, enquanto resultado da institucionalização dos programas de pósgraduação e pesquisa, é ainda bastante limitada e relativamente pouco expressiva. Esta afirmativa que para alguns poderia parecer forte, não é, contudo, de difícil comprovação. Considerando o grande número de programas pós-graduados existentes no país seria de se esperar, naturalmente, a produção de um número bastante mais significativo de trabalhos de maior destaque" (grifo meu) (Maranhão, 1982).

Cada avanço carrega consigo a corrente pesada da necessidade de se tornar reproduzível. Mas dá-se, sem dúvida, em um quadro de competência que na medida em que é transmitido vai na direção de uma modernização e racionalização da atividade científica consideráveis, a ciência social brasileira competindo favoravelmente na arena internacional pelo menos no que diz respeito a conhecimento do país, explorando temas significativos antes virgens ou privilégio dos "brasilianistas". O problema se agrava quando às limitações (todos as têm) desse modelo acrescentam-se dificuldades à sua própria reprodução, a tensão entre saber e não-saber que antes legitimava a tarefa dos educadores e dava valor aos ritos de passagem tendendo a se aguçar e a fugir ao controle.

Além da hipótese de que: "pode-se argüir que um bom número de sociólogos que trabalham nos programas e centros localizados nestas áreas (OGV: eixo Rio-São Paulo, onde se concentraria a produção), profissionais e professores de renome, produziriam e publicariam seus trabalhos 'com a pós-graduação ou sem ela..." (Maranhão, 1982), um bom indicador dessa "crise" são as próprias teses e dissertações, que representam boa parte da nova produção; a ponto de hipótese alternativa à acima ser a de que os pesquisadores sênior tendam a passar a expressar-se vicariamente através de seus alunos pela própria lógica da situação, a que não são estranhos os crescentes encargos da burocracia acadêmica. O problema está em que esses trabalhos nos últimos tempos crescentemente não se completam ou, então, apresentam taxa de inovação em tendência de baixa e de epigonismo em alta, mesmo avaliadas pelos padrões do 
modelo, numa espécie de exacerbação caricatural de algumas das suas tendências.

\section{VII}

Estamos, portanto, diante de um grupo social, profissional (não mais simples intelligentzia) e de pressões concretas de várias ordens. E esses dois elementos se combinam: as próprias contradições da auto-imagem construída criando uma hipersensibilidade às pressões. Aquilo que parecia democratização relativa em relação à "oligarquia" anterior, quando as demandas sociais correm mais livremente aparece como mais um projeto "oligárquico". E, diante dele, pressiona-se mais e mais contra seus próprios padrões: colocar-se a serviço das urgências da política e das questões sociais, incorporar massas crescentes de estudantes independentemente da capacidade de "formá-los" etc. Não se trata mais apenas de crítica a um modelo e seus limites. Trata-se também de constatar a sua própria dificuldade em se reproduzir, quaisquer que sejam seus méritos e deméritos.

As pressões se tornam particularmente eficazes dado o fato de que de qualquer maneira as atividades em ciências sociais cresceram muito nos últimos anos. Embora em situações de crise essa escala de atividades - como, aliás, nos próprios centros "metropolitanos" se veja ameaçada, a ameaça deve ser também interpretada como uma maneira de forçar as ciências sociais a cumprir determinadas expectativas não necessariamente de forma político-partidária, mas ligadas ideologicamente à "construção da nacionalidade"; à qual, mesmo "espontaneamente", os cientistas sociais não 810 de modo algum estranhos (Peirano, 1980). As "lamúrias" dos cientistas sociais quanto ao seu tratamento desprivilegiado em relação a outras áreas são também algo que deverá ser relativizado e contextualizado: tratando-se de verdade geral, não aplicável estritamente ao Brasil e atribuível ao "atraso", são elas mesmas um elemento a mais num jogo de forças que são também, morais.

É evidente que não se trata de abstratamente propor utopias. Todavia, fazer sociologia de "si" não é a mesma coisa que estudar o "outro". Assim, talvez seja permissível levantar algumas proposições que envolvam um juízo ou, pelo menos, que não estejam plenàmente demonstradas; desde que não sejam lidas como estranhas ao próprio objeto sociológico tratado. Já que produto da inserção dentro da problemática analisada, no mínimo constituem do ponto de vista do leitor mais um elemento dessa sociologia, cujo significado ele alcançará melhor do que o autor do texto.

Nesse espírito é que se seguem algumas afirmações, direta ou indiretamente apoiadas na sua própria apresentação e/ou na análise anterior, que representando incoerência relativa em um texto crítico em relação às razões práticas, serve por isso mesmo para ilustrar o lado de jogo de nossa atividade.

\section{VIII}

1) Embora a auto-imagem de cada grupo comprometido com determinado arranjo institucional tenda a marcar a sua diferença, isto 
deve ser visto como mais um elemento da sua afirmação, relevante em si mesmo, porém não excludente de certos elementos de continuidade, sobretudo esse próprio mecanismo de afirmação.

2) Aquilo que se designou por ciência social pré-64 (representada por sua expressão máxima) e pós-64 expressam identidades e estilos que se contrastam (em ambas as direções, já que a primeira é reinterpretada a posteriori também por seus protagonistas) e por essa e outras razões "de fato" apresentam diferença; apesar - e para além dos contrastes ideológicos construídos — de o pré-64 ser portador de uma utopia que em boa parte serviria de base para as modificações posteriores e a que não são estranhas as alterações por que passava a sociedade brasileira desde o pós-guerra.

3) A ciência social "pós-64" caracteriza-se nas suas expressões mais de ponta e originais em relação ao momento anterior por um compromisso maior com a formação de pessoal e com a pesquisa empírica em oposição ao exercício teor ético; de que se seguem consequiências não só no volume da produção intelectual, como também no seu caráter, sobretudo no sentido de criação de um padrão de trabalho, de um estilo e de objetivos que inclusive para serem reproduzíveis em escala significativamente mais ampla são construídos de maneira diferente.

4) Essa prática de formação, que se combina com uma ideologia igualitarista, passa a informar o conjunto da produção, constrangendo as possibilidades de iniciativa e inovação. Segue-se tendência, juntamente com a racionalização da atividade intelectual e o aumento do leque temático e sua consistência interna, também à sua burocratização.

5) Essa burocratização, por sua vez, articula-se com a própria defesa dos interesses corporativos de um grupo em fase mais avançada de profissionalização (em contraste com a autoimagem anterior, mais próxima da de uma intelligentzia) através de suas associações e da busca de articulação com outros setores da "sociedade civil", os quais então, num processo retro alimentador, passarão a construir expectativas de compromisso em relação ao comportamento dos cientistas sociais que influirão na sua prática.

6) Há, aí, uma contradição: a afirmação do grupo implicando submissão a critérios "externos". O que se agrava quando a essas pressões "externas" se somam interesses em romper as barreiras do próprio grupo representadas por um padrão de trabalho.

7) As maneiras de se lidar com essa contradição conduzem necessariamente ao terreno da política, não só no seu sentido mais amplo, como também no sentido de como se conciliam do ponto de vista do cientista social esses vários elementos.

8) Nesse ponto, provavelmente o terreno mais seguro só vai até a constatação dessa situação; o que por si já implica ir além das camuflagens que se colocam usualmente ao nível das aparências.

9) "Soluções" existem várias ou, talvez, não exista nenhuma. A sabedoria antiga já dava como solução para a questão do melhor governo alguma forma de combinação entre os vários modelos. O "governo" das nossas ciências sociais provavelmente não escapa à 
regra. De qualquer maneira, um exercício nessa direção — espécie de adendo - estará incluído no âmbito do esforço comparativo aqui realizado, ajudando a relativizar cada elemento da comparação e com isso, na pior das hipóteses, contribuindo para entendê-los melhor; embora por um caminho em que o autor se deixa apanhar como parte do debate.

10) Provavelmente aquilo que em termos de treinamento e socialização se desenvolveu nos redutos da pós-graduação nos últimos anos poderia ser, hoje, adequado ao ensino graduado, e, à medida que se afirmem os níveis mais avançados da pós-graduação, mantendo-se em parte também nos seus primeiros níveis. Com essa inversão, utilizando recursos que se tomaram disponíveis atacar-se-ia o tipo de ensino básico — amorfo e precocemente teoricista — que justifica o padrão dominante na pós-graduação pela necessidade de suprir lacunas, realizando tarefas relacionadas às "razões práticas" e à profissionalização stricto sensu.

11) Ao mesmo tempo, algo do sentido mais clássico da educação deveria ser incluído na concepção de formação de um cientista social sênior, contra-atacando os excessos da especialização e do praticismo e valorizando·se uma concepção de scholarship.

12) Recuperados esses valores clássicos, deveria-se evitar, por sua vez, a sua fossilização, antes utilizando-os para liberar vias pessoais de pesquisa e afirmação, a ponto de superar o próprio classicismo pela valorização da variação na variação, a multiplicidade nos modos de proceder, tornada inevitável pela própria falência das bases do "saber enciclopédico".

13) Possivelmente (hipótese) com isso se vá ter um efeito indireto de aumento da produtividade naquela parte da população acadêmica morta ou moribunda cuja improdutividade não se deva a uma reação por baixo aos padrões vigentes, mas a uma resistência aos aspectos constrangedores e limitadores desses mesmos padrões.

14) Nesse contexto seria razoável buscar "convencer" a sociedade (e os próprios cientistas sociais) da legitimidade da sua atividade para além do seu valor prático em qualquer direção. $\mathrm{O}$ seu "valor" para a sociedade estaria muito mais em um autoconhecimento como subproduto; tanto mais objetivo quanto menos amarrado a interesses explícitos e imediatos nessa direção. E tanto mais aceitável quanto mais a sociedade se fortaleça e se considere digna de se dar esse "prazer" e competente para traçar os seus rumos sem orientações partidas de uma elite de "sábios", abertamente assumidos enquanto tais ou camuflados sob o manto do serviço, do compromisso, do engajamento ou mesmo da "ciência", quando esta tome como objeto necessário de sua atividade a criação de uma imagem da sociedade que lhe sirva de suporte ideológico.

15) Restarão como grande questão ligada â anterior as pressões contrastantes â elitização e â massificação. Na verdade, os elementos sugeridos são já representações de formas de lidar com essa contradição. Provavelmente o que se pode concluir é que para além das ilusões de cada momento o problema é recorrente em toda a nossa época histórica e os movimentos da sociedade como um todo 
não podem, nesse particular, evidentemente ser ignorados. Se há 150 anos o velho Tocqueville já constatava ser impossível "evitar" a igualdade, a liberdade devendo ser garantida pela criação de "pessoas aristocráticas" coletivas, é possível que hoje mais do que nunca seja essa a direção; sobretudo em países que atravessam momentos críticos na formação de uma sociedade de massas. Mas para isso é preciso que se assuma plenamente essa "pessoa", transcendendo os momentos de autodefesa em que se tende mais a reagir (o que incluiria de certa maneira tanto a postura dos "chato-boys" quanto a dos novos ascetas da pesquisa) e desenvolvendo a partir de si as suas virtualidades.

16) Nesse processo os cientistas sociais brasileiros levam a imensa vantagem de possuir o patrimônio de obras individuais cuja existência pode servir de respaldo à tentativa de evitar a mediocrização e cuja real integração e revalorização num movimento mais amplo lhes dará por sua vez maior fôlego na inspiração de esforços criativos similares.

\section{IX}

Certamente já é hoje banal dizer-se que todo pensamento é comprometido. A ideia puramente liberal do pensamento neutro pouco explica; apenas descreve a aparência de um estado eventual de um campo de forças, por vezes cristalizado. Mas não é necessário fazer da necessidade uma virtude abstrata. Pode-se imaginar um pensamento cujo "interesse" esteja justamente no estímulo à busca da objetividade; em que a sua afirmação, a sua potência, esteja comprometida com isso. É essa, provavelmente, a "pessoa" da comunidade científica a ser desenvolvida. É essa, talvez, uma leitura simpática da intuição manheimiana; dependente de um ambiente institucional, mas também, não só de um "espírito", como igualmente de uma vontade, que não se deixe seduzir pela eficácia dos atalhos e que pense as instituições e as expectativas sobretudo no sentido de sua utilização lúcida, ultrapassando-as quando necessário e, em pensamento, até como método.

Não parece adequado supor que um determinado padrão de trabalho tenha sempre um significado em si. Seguidamente só o tem enquanto resposta afirmação em relação a outro. À medida que isso é percebido:

1) Ele pode ser relativizado.

2) E eventualmente, o que seria no caso um programa "maximalista" que obrigaria a uma reestruturação e revisão dos limites da própria comunidade, poder-se-ia vislumbrar a hipótese de relativizar a referência necessária a outro, construindo a possibilidade de criações mais autônomas e menos reativas.

A meio caminho entre 1 e 2 dever-se-ia saber distinguir nos desvios em relação a um padrão o que a partir de sua própria perspectiva poderia ser visto como "resquício" de um outro, e o que existe já de elementos (retro alimentados ou não por padrões "ultrapassados") de sua superação. Mesmo porque, assumindo uma postura não teleológica as coisas aparecerão menos separadas, 
reafirmando de alguma maneira um', eterno retomo — pelo menos pela impossibilidade de fixação definitiva de qualquer padrão — e a necessidade de uma permanente reapropriação. A crise pela qual passamos não é privilégio de nosso "atraso". Apesar de suas especificidades, faz parte de uma crise mais geral - tanto institucional, quanto teórica — hoje cada vez mais reconhecida. A maneira aguda e concentrada pela qual a vivemos e a nossa competência podem, porém - muito mais do que nos damos conta - fazer com que nos transformemos em participantes ativos nesse drama maior, contribuindo para a sua superação. Se possível, superação institucional; mas sobretudo superação de quadros gerais de pensamento e atitudes que afortunadamente e para privilégio de quem o presencia hoje se tornam cada vez mais contestáveis.

\section{Bibliografia}

ABRANCHES, Sergio Henrique, As ciências sociais e o Estado, IUPERJ, 1981, mimeo.

CARDOSO, Fernando Henrique, Capitalismo e Escravidão no Brasil Meridional, $2^{\text {a }}$ ed., Ed. Paz e Terra, 1977.

FERNANDES, Florestan, A Sociologia no Brasil, Ed. Vozes, 1977; A Condição de Sociólogo, HUCITEC, 1978.

LAMOUNIER, Bolivar, Expansão e institucionalização das ciências sociais no Brasil: um estudo preliminar, mn., 1981.

MARANHÃO, Silvio Marcelo, A pós-graduação e a pesquisa em sociologia: notas para uma avaliação, mn., 1982.
PEIRANO, Mariza G. S., The Anthropology of Anthropology: the Brazilian case, tese de doutoramento, Universidade de Harvard, jul. 1980.

SANTOS, Wanderley Guilherme dos, "A imaginação político-social brasileira", Dados, n. 2/3,1967.

SCHWARTZMAN, Simon, Formação da Comunidade Cientifica no Brasil, FINEP/ Companhia Editora Nacional, 1979.

VELHO, Otávio Guilherme, "A propósito da publicação de uma coletânea", Sociedade e Agricultura, Zahar Ed., 1982. 